BUDAPESTI CORVINUS EGYETEM

\title{
A BETEGSÉG KÖLTSÉG ÉS AZ ÉLETMINŐSÉG SZEREPE A FORRÁSALLOKÁCIÓS DÖNTÉSEK SORÁN AZ EGÉSZSÉGÜGYBEN
}

DOKTORI ÉRTEKEZÉS

Témavezetők: Prof. Péntek Márta, és Prof. Gulácsi László Dsc

Beretzky Zsuzsanna

Budapest, 2020 


\title{
BERETZKY ZSUZSANNA
}

\author{
A BETEGSÉG KÖLTSÉG ÉS AZ \\ ÉLETMINŐSÉG SZEREPE A \\ FORRÁSALLOKÁCIÓS DÖNTÉSEK \\ SORÁN AZ EGÉSZSÉGÜGYBEN
}


Egézségügyi Közgazdaságtan Tanszék

\section{Témavezetők: Prof. Péntek Márta, és Prof. Gulácsi László Dsc.}


Budapesti Corvinus Egyetem

Gazdálkodástani Doktori Iskola

\section{A BETEGSÉG KÖLTSÉG ÉS AZ ÉLETMINŐSÉG SZEREPE A FORRÁSALLOKÁCIÓS DÖNTÉSEK SORÁN AZ EGÉSZSÉGÜGYBEN}

Doktori Értekezés

Beretzky Zsuzsanna

Budapest, 2020 



\section{TARTALOMJEGYZÉK}

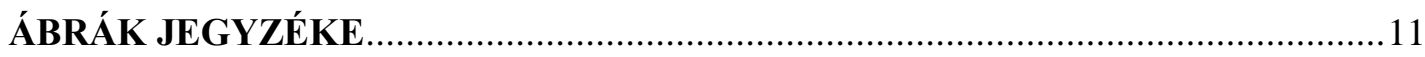

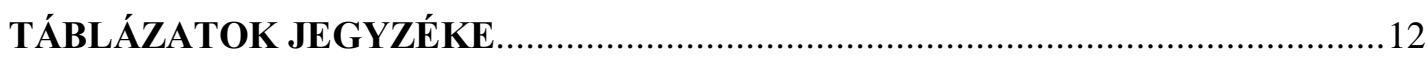

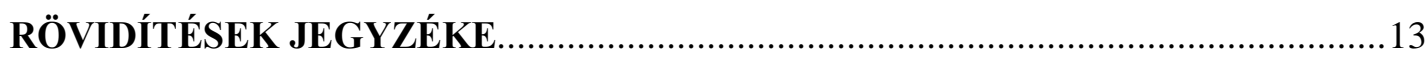

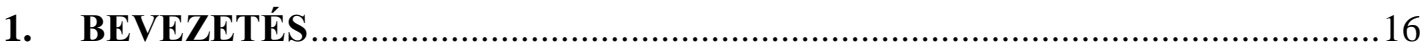

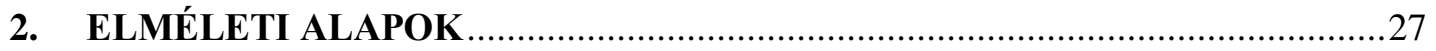

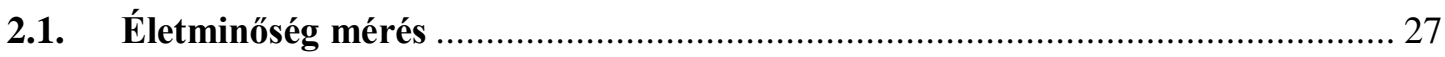

2.1.1. Az EQ-5D kérdő́ív ........................................................................... 28

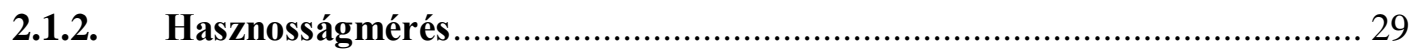

2.1.3. Betegségspecifikus kérdôívek: a bőrgyógyászati életminőség index ............ 30

2.1.4. Az életminőséggel súlyozott életév koncepció bemutatása .......................... 30

2.1.5. Az egészségi állapot és jól-lét mérése ……............................................. 31

2.1.5.1. Minimum European Health Module (MEHM) .......................................... 31

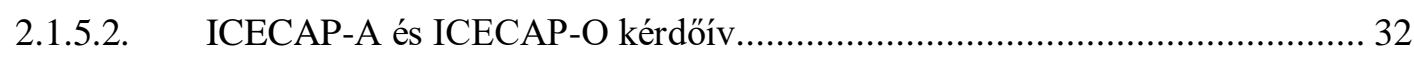

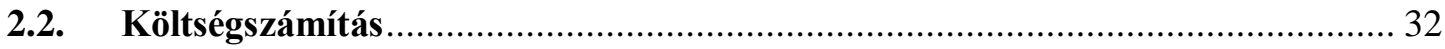

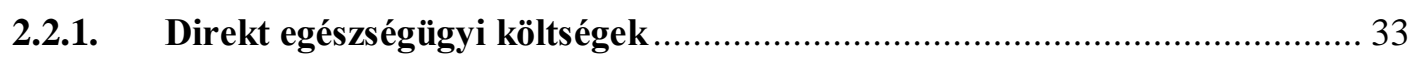

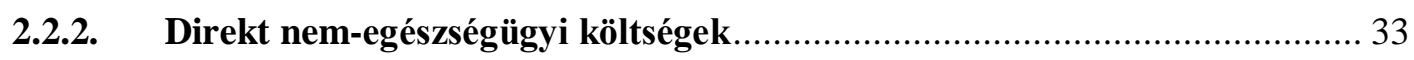

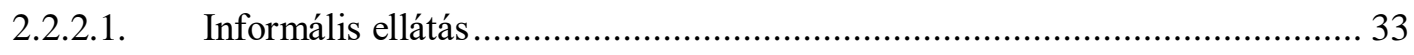

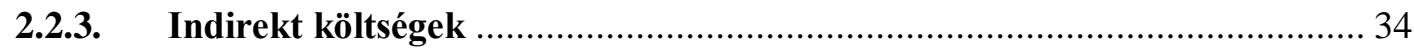

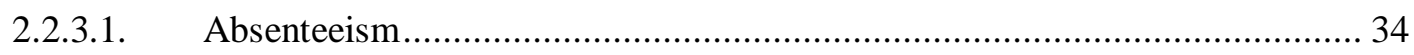

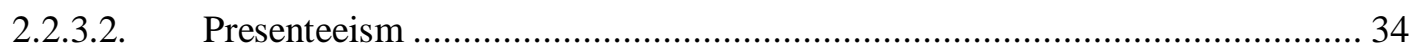

2.2.3.3. A termelékenységköltség (productivity loss) mérése: Work Productivity and

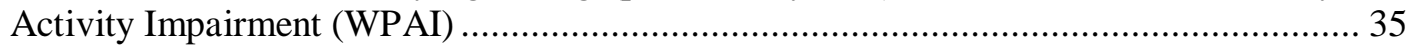

2.2.4. Az egészségügyi technológiaértékelés szerepe, egészségpolitika és

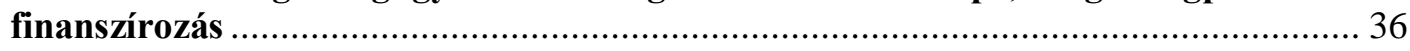

2.2.5. Magyarországi egészségügyi online költség katalógus ............................... 38

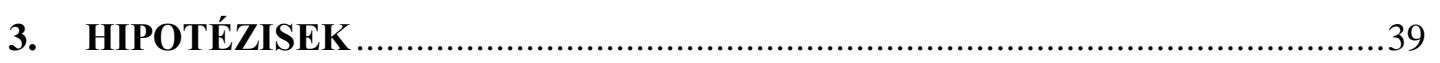

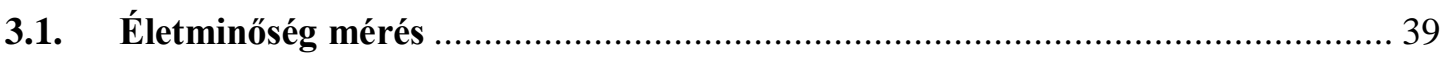

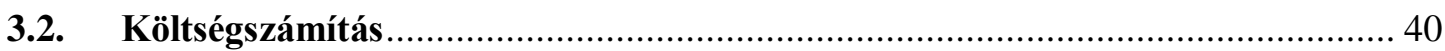

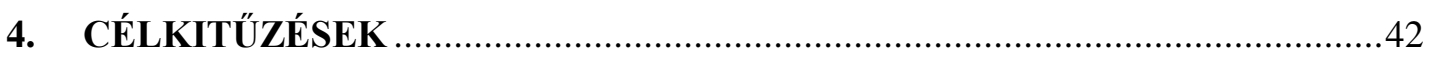

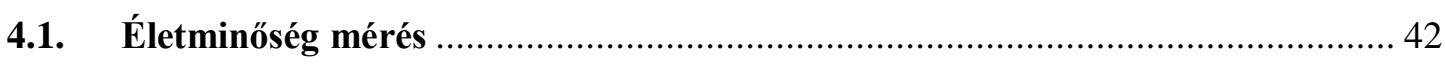

4.1.1. Az európai, lengyel, szlovén és UK EQ-5D-3L értékkészlet összehasonlítása 18 krónikus betegségben; hazai adatok alapján .................................................. 42

4.1.2. A DLQI kérdőív „,nem releváns” válaszainak részletes elemzése ................ 42

4.1.3. A magyarországi lakosság egészségi állapota és munkaképessége............... 43

4.1.4. Informális ellátás és meghatározó tényezői krónikus betegségekben: magyarországi kutatások összehasonlító elemzése .................................................. 43

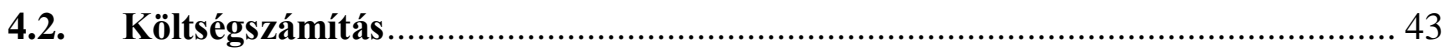


4.2.1. Az informális ellátás költsége krónikus betegségekben: magyarországi kutatások összehasonlító elemzés

4.1.1. Betegségköltség vizsgálatok áttekintése kilenc Közép-Kelet-Európai

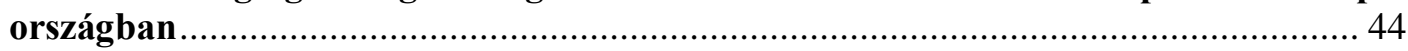

4.1.2. Magyarországi egészségügyi online költség katalógus ….......................... 44

5. MÓDSZEREK.

5.1. Életminőség mérés

5.1.1. Az európai, lengyel, szlovén és UK EQ-5D-3L értékkészlet összehasonlítása 18

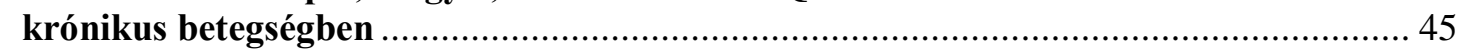

5.1.1.1. A vizsgált EQ-5D-3L értékkészletek....................................................... 45

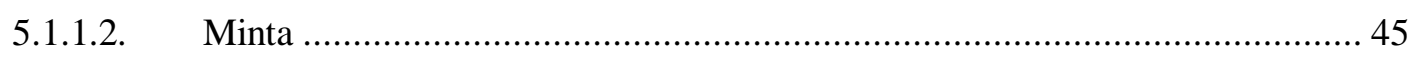

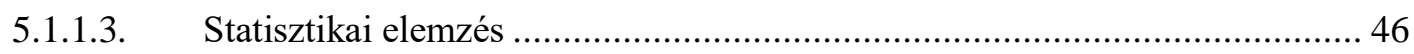

5.1.2. A DLQI kérdőív „,nem releváns” válaszainak részletes elemzése .................... 46

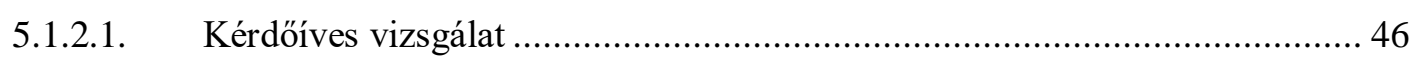

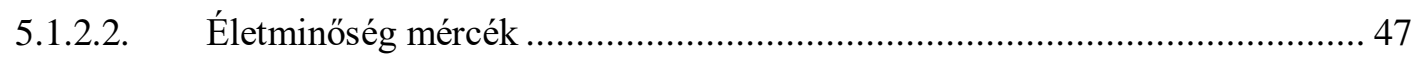

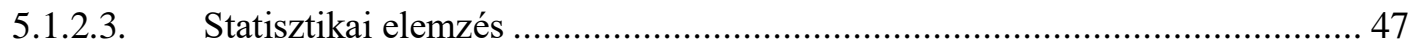

5.1.3. A magyarországi lakosság egészségi állapota és munkaképessége …………... 48

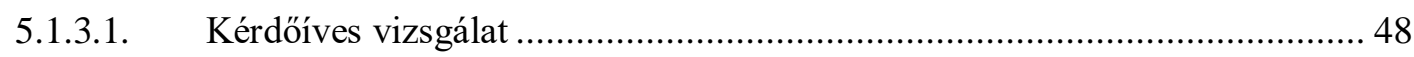

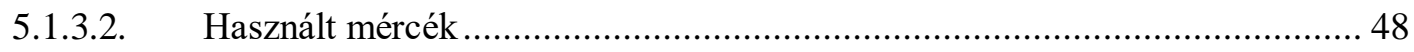

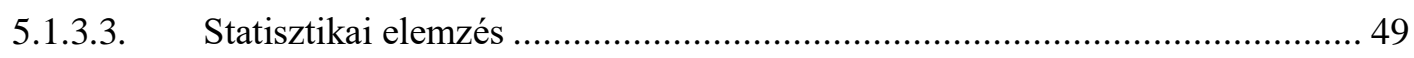

5.1.4. Informális ellátás és meghatározó tényezői krónikus betegségekben: magyarországi kutatások összehasonlító elemzése ......................................................... 49

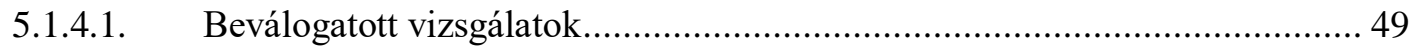

5.1.4.2. Informális ellátást célzó kérdések a vizsgálatokban.................................. 49

5.1.4.3. Egészségi állapot felmérése EQ-5D kérdőívvel a vizsgálatokban ................. 50

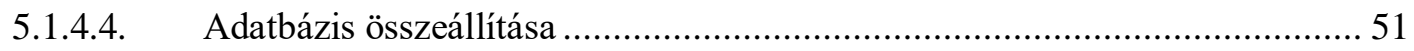

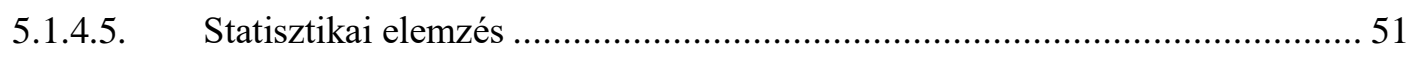

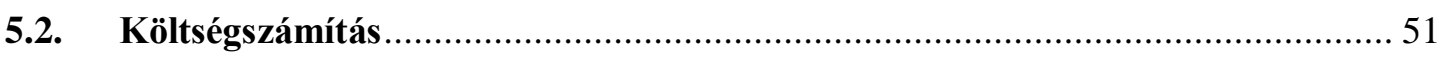

5.2.1. Az informális ellátás költsége krónikus betegségekben: magyarországi kutatások összehasonlító elemzése .......................................................................... 51

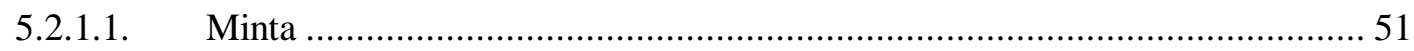

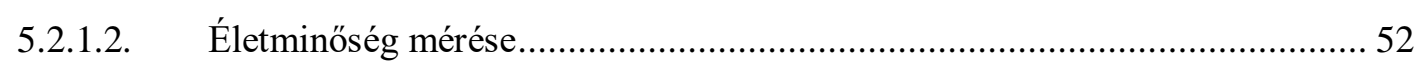

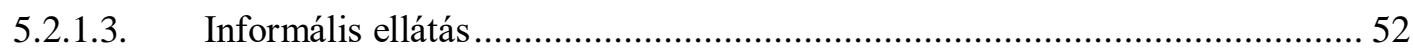

5.2.2. Betegségköltség vizsgálatok áttekintése kilenc Közép-Kelet-Európai országban

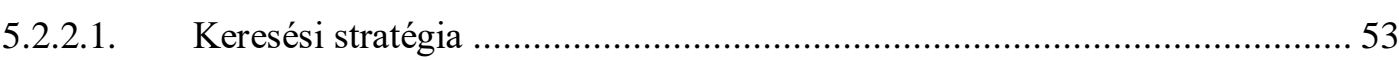

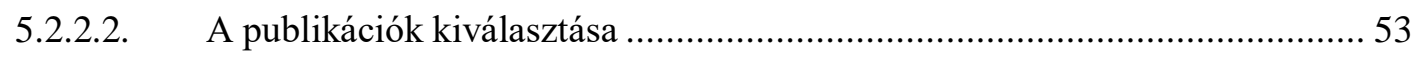

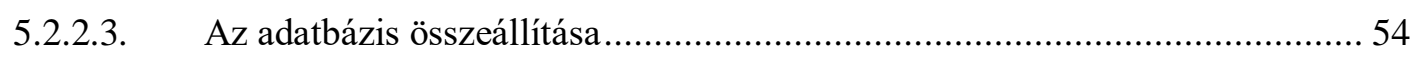

5.2.3. A Magyarországi egészségügyi online költség katalógus ................................ 54

5.2.3.1. Betegségköltség (cost of illness) publikációk keresése ................................. 55

5.2.3.2. Cost-effectiveness, budget-impact analysis publikációk keresése .................. 55 
5.2.3.3. Magyarországi, magyar nyelvü irodalomban történő kézi keresés ................ 56

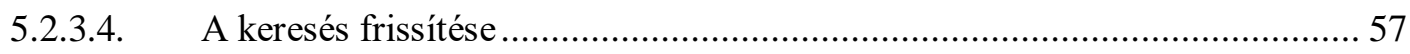

5.2.3.5. A Magyarországi egészségügyi online költség katalógus összeállítása .......... 58

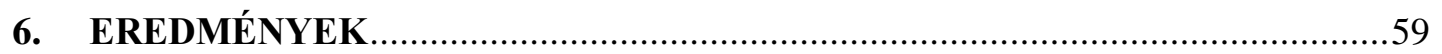

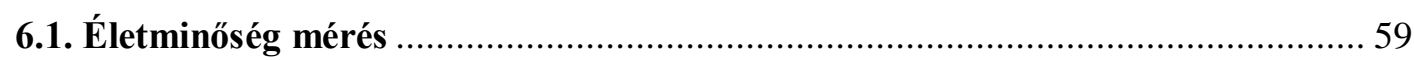

6.1.1. Az európai, lengyel, szlovén és UK EQ-5D-3L értékkészlet összehasonlítása 18

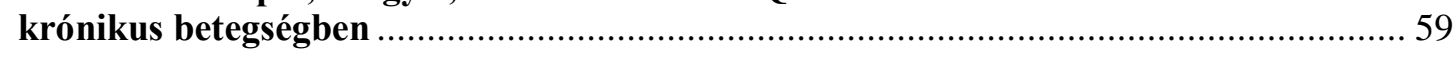

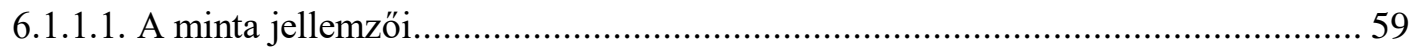

6.1.1.2. Az EQ-5D-3L dimenziókban jelentett problémák ............................................ 62

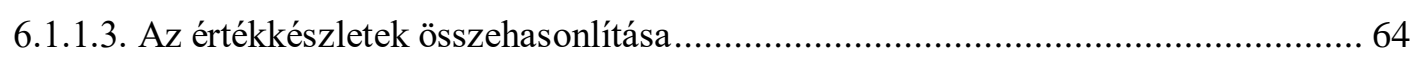

6.1.2. A DLQI kérdő́v „nem releváns” válaszainak részletes elemzése ......................... 73

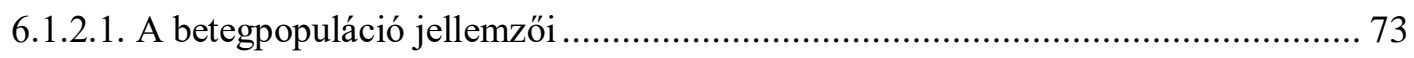

6.1.2.2. A „nem releváns” válaszok részletes elemzése ............................................... 73

6.1.2.3. A „nem releváns” válaszok magyarázó tényezői ............................................... 75

6.1.3. A magyarországi lakosság egészségi állapota és munkaképessége …………........ 76

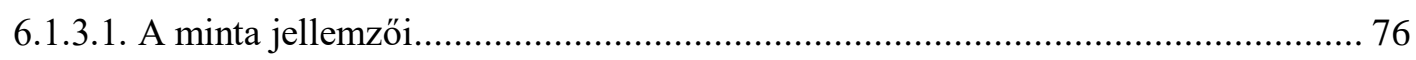

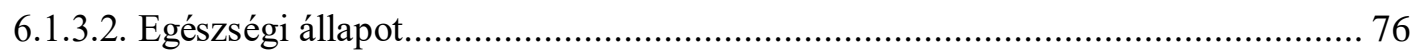

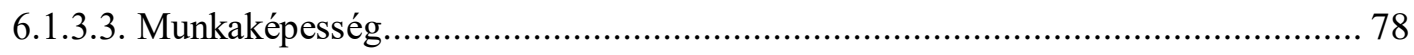

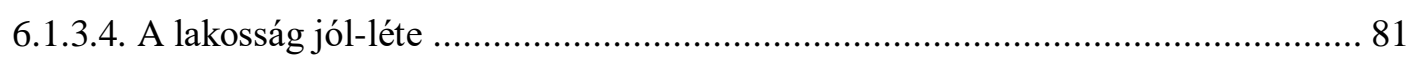

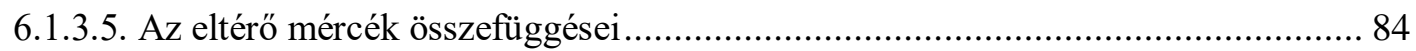

6.1.4. Informális ellátás és meghatározó tényezői krónikus betegségekben: magyarországi

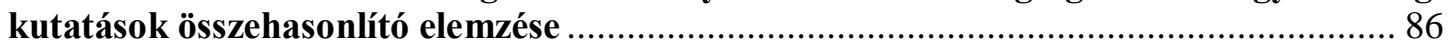

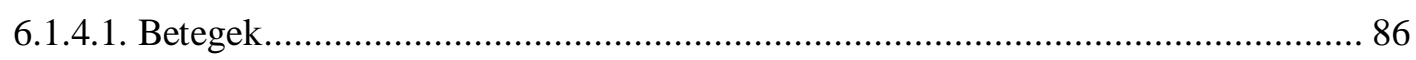

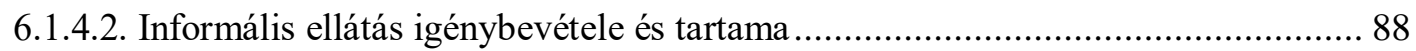

6.1.4.3. A betegek egészségi állapota az EQ-5D-3L alapján .......................................... 90

6.1.4.4. Informális ellátást igénybe vevők és nem vevők összehasonlítása ...................... 91

6.1.4.5. Az informális ellátást meghatározó tényezők: regressziós modell ...................... 94

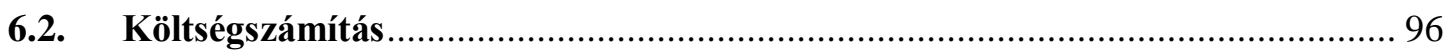

6.2.1. Az informális ellátás költsége krónikus betegségekben: magyarországi kutatások

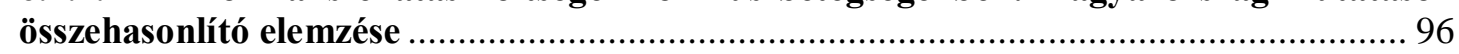

6.2.1.1. Az EQ-5D-3L egyes dimenzióiban problémát jelző betegek informális ellátás

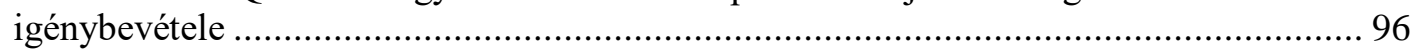

6.2.1.2. A legrosszabb egészségi állapotban levő betegek informális ellátása .................. 97

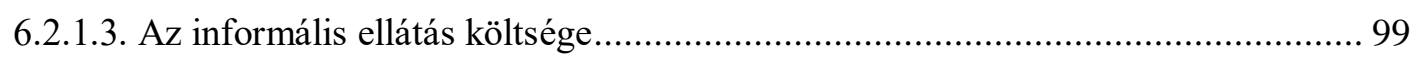

6.2.1.4.Informális ellátás költségét meghatározó tényezők .......................................... 101

6.2.1.5. Az informális ellátás éves költségei ............................................................... 101

6.2.2. Betegségköltség vizsgálatok áttekintése kilenc Közép-Kelet-Európai országban 103

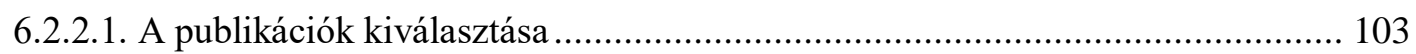

6.2.2.2. A Beválogatott publikációk jellemzői........................................................... 103

6.2.2.3. Módszerek a beválogatott publikációkban ..................................................... 105 
6.2.2.4. Egyes betegségek költségeinek összehasonlítása 109

6.2.3. Magyarországi egészségügyi online költség katalógus .................................... 110

6.2.3.1. A beválogatott publikációk jellemzői..................................................... 110

6.2.3.2. A publikációkban megjelenő klinikai területek ............................................ 112

6.2.3.3. A publikációk megoszlása: hazai és Magyarország részvételével zajló nemzetközi kutatások

6.2.3.4. A publikációk Scimago besorolás szerinti megoszlása ........................................... 114

6.2.3.5. Költségadatok a beválogatott publikációkban ................................................ 115

6.2.3.6. Az adatgyüjtés - erőforrás felhasználás - módszertana és egészségügyi közgazdaságtani elemzések módszerei a beválogatott publikációkban ..................................................... 117

6.2.3.7. A publikációkban megjelelő költségek adatforrásai ........................................... 121

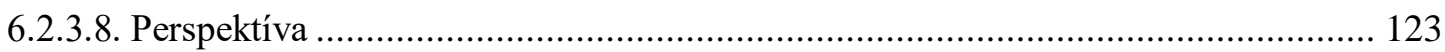

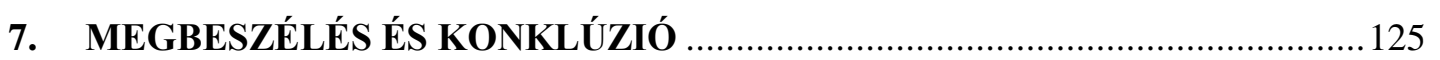

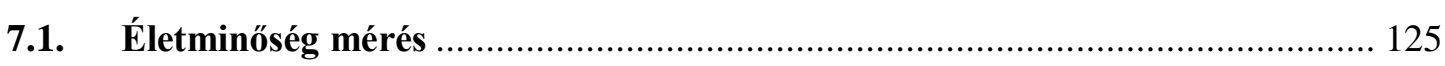

7.1.1. Az európai, lengyel, szlovén és UK EQ-5D-3L értékkészlet összehasonlítása

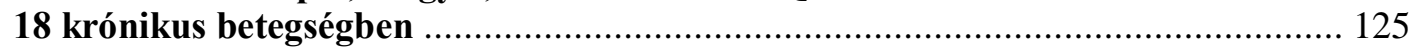

7.1.2. A DLQI kérdőív „,nem releváns” válaszainak részletes elemzése .............. 127

7.1.3. A magyarországi lakosság egészségi állapota és munkaképessége............. 129

7.1.4. Informális ellátás és meghatározó tényezői krónikus betegségekben: magyarországi kutatások összehasonlító elemzése ............................................... 131

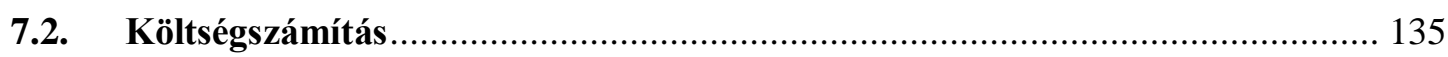

7.2.1. Az informális ellátás költsége krónikus betegségekben: magyarországi kutatások összehasonlító elemzés 135

7.2.2. Betegségköltség vizsgálatok áttekintése kilenc Közép-Kelet-Európai országban. 137

7.2.3. A Magyarországi egészségügyi online költség katalógus ......................... 139

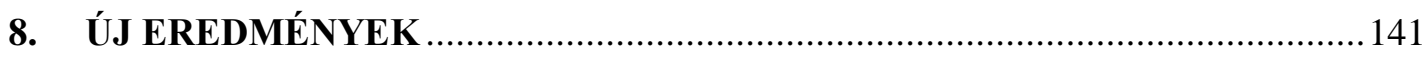

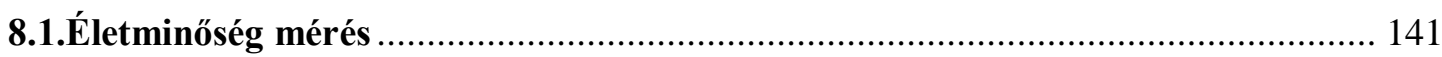

8.1.1. Az európai, lengyel, szlovén és UK EQ-5D-3L értékkészlet összehasonlítása

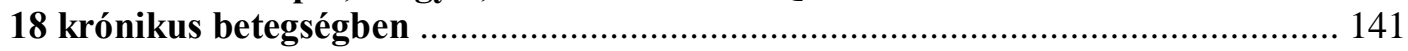

8.1.2. A DLQI kérdőív „nem releváns” válaszainak részletes elemzése ............... 141

8.1.3. A magyarországi lakosság egészségi állapota és munkaképessége............. 141

8.1.4. Informális ellátás és meghatározó tényezői krónikus betegségekben: magyarországi kutatások összehasonlító elemzése ............................................... 142

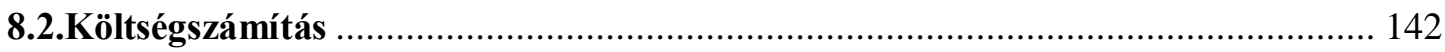

8.2.1. Az informális ellátás költsége krónikus betegségekben: magyarországi kutatások összehasonlító elemzése 142

8.2.2. Betegségköltség vizsgálatok áttekintése kilenc Közép-Kelet-Európai

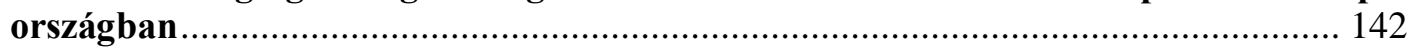

8.2.3. Magyarországi egészségügyi online költség katalógus …......................... 142

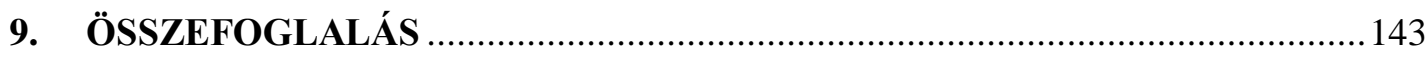

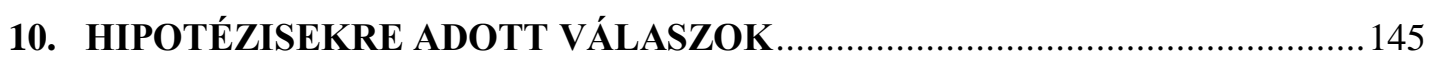




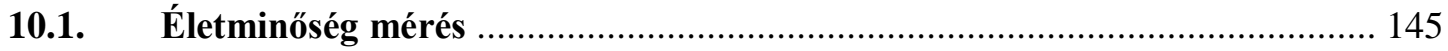

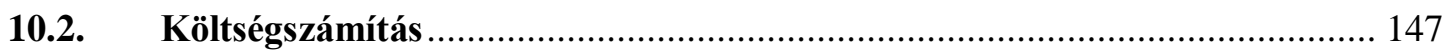

11. A DOLGOZAT MEGÍRÁSÁHOZ FELHASZNÁLT SAJÁT PUBLIKÁCIÓK

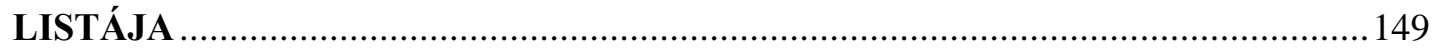

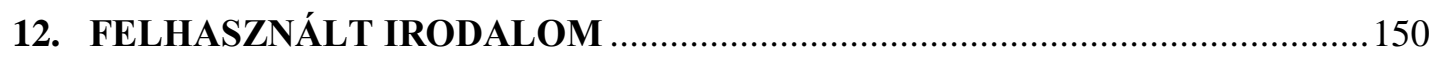




\section{ÁBRÁK JEGYZÉKE}

1. Ábra A dolgozatban ismertetett kutatások összefüggései.

2. Ábra Az EQ-5D-3L dimenziókban jelentett problémák megoszlása (\%)

3. Ábra Egészségi állapotok hasznossága a négy EQ-5D-3L értékkészlettel.....

4. Ábra Az értékkészletek a beteg szubjektív egészség értékelése szerinti összehasonlítása ..... 68

5. Ábra A UK értékkészlettől való eltérések (DB) (EQ-5D-3L index érték eltérésekben

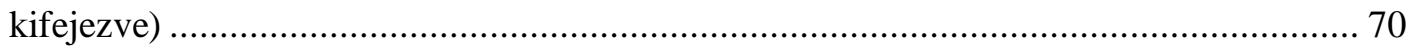

6. Ábra A “nem releváns” válaszok megoszlása az egyes DLQI kérdésekben (\%) .................... 74

7. Ábra A "nem releváns" válaszok megoszlása DLQI pontszám szerint (\%) .......................... 75

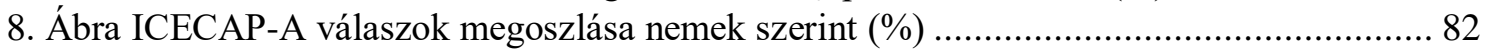

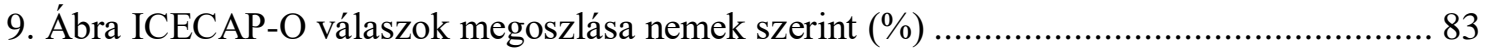

10. Ábra Az informális ellátást igénybe vevők aránya betegségtípusonként (\%) és a betegcsoportok életkora.

11. Ábra Igénybe vett informális ellátás átlagos ideje diagnózisonként (óra/hét), betegeként napi

24 illetve 8 óra limit alkalmazásával

12. Ábra Problémát jelzők aránya (\%) az egyes EQ-5D-3L dimenziókban az informális ellátásban részesülő és nem részesülő alcsoportokban.

13. Ábra Az informális ellátást igénybe vevő alcsoportban az informális ellátás átlagos ideje (óra/hét), betegenként napi 8 illetve 24 óra limit alkalmazásával.

14. Ábra A publikációkban megjelenő klinikai területek százalékos megoszlása . 105

15. Ábra Azonosított publikációk száma az egyes években (publikáció éve és nyelv szerint), n (db)

16. Ábra A beválogatott publikációk klinikai terület szerinti megoszlása (\%) - Betegségek Nemzetközi Osztályozása (BNO)

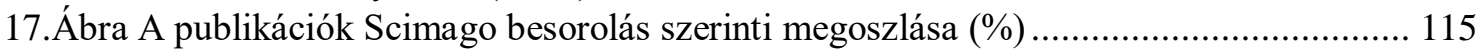

18. Ábra A fekvő-és járóbeteg költségek megoszlása a publikációkban n (db) ........................ 116

19. Ábra A publikációk megoszlása a bennük szereplő költségek szerint (\%)......................... 117 


\section{TÁBLÁZATOK JEGYZÉKE}

1.Táblázat A mintában szereplö betegek demográfiai jellemzői

2.Táblázat A négy értékkészlettel számolt EQ-5D-3L index értékek diagnózisok szerint (átlag (SD)) .66

3.Táblázat A betegségteher összehasonlítása a négy értékkészlettel, diagnózisok szerint

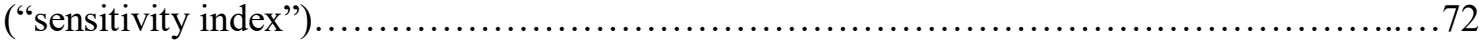

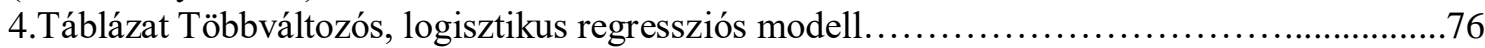

5.Táblázat A válaszadók jelen egészségi állapota (MEHM), $\mathrm{N}=2023 \ldots \ldots \ldots \ldots \ldots \ldots \ldots \ldots \ldots . \ldots \ldots 77$

6.Táblázat A válaszadók szocio-demográfiai jellemzői, egészségi állapota és munkaképessége...................................................................79

7.Táblázat Az egyes mércék és válaszadók jellemzőinek összefüggései (korrelációs együtthatók)

8.Táblázat A betegek jellemzői az egyes diagnózisokban................................. 87

9.Táblázat Informális ellátás igénybevétel alapján képzett csoportok demográfiai és egészségi állapotának jellemzői.

10.Táblázat Lineáris regressziós modell az igénybe vett informális ellátás idejére (óra/hét) vonatkozóan.

11.Táblázat Az EQ-5D egyes dimenzióiban problémát jelentők informális ellátás igénybe vétele

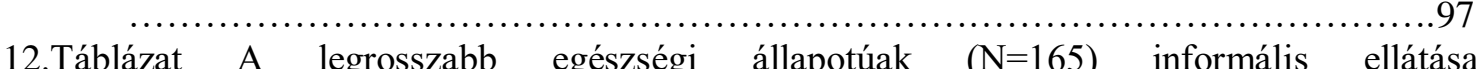
12.Tablazat A legrosszabb egészségi állapotúak $(\mathrm{N}=165)$ informális ellátása

13.Táblázat Az igénybe vett informális ellátás költsége $(\mathrm{Ft} / \mathrm{b}$ eteg/hét) betegségtípusonként

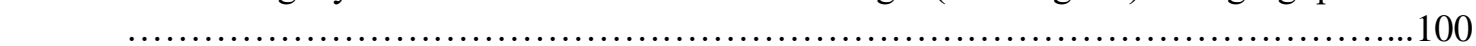

14.Táblázat Az informális ellátás becsült költsége/beteg/év (HUF) Magyarországon...........102

15.Táblázat A betegségköltség kutatások jellemzői........................................ 107 


\section{RÖVIDÍTÉSEK JEGYZÉKE}

\begin{tabular}{|c|c|}
\hline AMD & időskori makula degeneráció (age-related macular degeneration) \\
\hline AP & artritisz pszoriatika (arthritis psoriatica) \\
\hline $\mathrm{BC}$ & húgyhólyagrák (bladder cancer) \\
\hline $\mathrm{BPH}$ & $\begin{array}{l}\text { jóindulatú prosztata megnagyobbodás (benign prostatic } \\
\text { hyperplasia) }\end{array}$ \\
\hline BIA & költségvetési hatás elemzés (Budget Impact Analysis) \\
\hline $\mathrm{BNO}$ & betegségek nemzetközi osztályozása \\
\hline CEA & költség-hatékonyság elemzés (Cost Effectiveness Analysis) \\
\hline $\mathrm{COI}$ & betegségköltség felmérés (Cost of Illness) \\
\hline CUA & költség-hasznosság elemzés (Cost-Utility Analysis) \\
\hline DB & betegségteher (disease burden) \\
\hline DCE & diszkrét választások módszerével (discrete choice experiment,) \\
\hline DLQI & $\begin{array}{l}\text { Bőrgyógyászati Életminőség Kérdőív ((Dermatology Life Quality } \\
\text { Index) }\end{array}$ \\
\hline EHIS & European Health Interview Survey \\
\hline EMMI & Emberi Erőforrások Minisztériuma \\
\hline EQ-5D & $\begin{array}{l}\text { egészségi állapot kérdőív (The 5-level EuroQoL Group's 5- } \\
\text { dimensions questionnaire) }\end{array}$ \\
\hline EUnetHTA & $\begin{array}{l}\text { Európai Egészségügyi Technológiaértékelési Hálózat (European } \\
\text { Network for Health Technology Assesment) }\end{array}$ \\
\hline GALI & Global Activity Limitation Indicator \\
\hline HBCS & Homogén betegségcsoportok \\
\hline HTA & $\begin{array}{l}\text { egészségügyi technológiák értékelése (health technology } \\
\text { assessment) }\end{array}$ \\
\hline ICECAP-A & ICEpop CAPability measure for Adults \\
\hline ICECAP-O & ICEpop CAPability measure for Older people \\
\hline
\end{tabular}


ICD-10

ICER

MEHM

NEAK

OEP

OAB

PASI

PRISMA

RA

RUD

QALY

QoL

SF-36

SG

SM

$\mathrm{SSc}$

TTO

VAS

WHO-5
Betegségek nemzetközi osztályozása (International Statistical Classification of Diseases and Related Health Problems 10th Revision)

inkrementális költséghatékonysági ráta (incremental costeffectiveness ratio)

Minimum European Health Module

Nemzeti Egészségbiztosítási Alapkezelő

Országos Egészségbiztosítási Pénztár

hiperaktív hólyagszindróma (overactive bladder)

psoriasis kiterjedési és súlyossági index" (Psoriasis Area Severity Index)

Preferred Reporting Items for Systematic Reviews and MetaAnalyses

reumatoid artritisz (rheumatoid arthritis)

Resource Utilization in Dementia (erőforrás-felhasználást mérő kérdőív demenciában)

életminőséggel korrigált életév (Quality-Adjusted Life Year)

életminőség (Quality of Life)

egészségügyi állapotot felmérő kérdőív (Short Form (36) Health Survey)

standard játszma (standard gamble)

szklerózis multiplex (sclerosis multiplex)

szisztémás szklerózis (systemic sclerosis)

időalku (Time Trade-Off)

vizuális analóg skála (Visual Analogue Scale)

WHO jól-lét kérdőív (World Health Organisation- Five WellBeing Index) 


\section{KÖSZÖNETNYILVÁNÍTÁS}

A dolgozatban szereplö kutatásokban a kutatás megtervezése, elökészitése, lebonyolitása és az eredmények feldolgozása során végig segitségemre voltak témavezetöim, Prof. Gulácsi László és Prof. Péntek Márta. A kutatások során szintén mindvégig segítségemre voltak hazai és külföldi kollégáink, társzerzőink, akikkel közösen folyattunk a munkát. Ezért a kutatások eredményeit a közös munkák és eredményeink tiszteletére többes szám elsö személyben ismertetem dolgozatomban. Dolgozatom megírásához és munkámhoz nyújtott segitségükért szeretnék köszönetet mondani, a Corvinus Egyetem Egészségügyi Közgazdaság Tanszék vezetöjének, Gulácsi Lászlónak és munkatársainak Péntek Mártának, Brodszky Valentinnek, Baji Petrának Rencz Fanninak és Zrubka Zsombornak. Mindannyiuknak köszönettel tartozom a közös munkáért és élményekért.

A dolgozat elkészitését az Innovációs és Technológiai Minisztérium által meghirdetett Felsőoktatási Intézményi Kiválósági Program támogatta, a Budapesti Corvinus Egyetem 'Pénzügyi és Lakossági Szolgáltatások' tématerületi programja (NKFIH-1163-10/2019) keretében. 


\section{BEVEZETÉS}

Az egészségügyi kiadások egyre növekvő mértékủek szerte a világon, így Európa országaiban és hazánkban is. Magyarországon az egy főre jutó egészségügyi kiadás az Európai Uniós átlag alatti. Magyarországon az egy főre jutó egészségügyi kiadás 1996\$ volt 2017-ben, még ugyanebben az évben Németországban 5848\$, Svédországban 5264\$, Dániában pedig 5025\$ volt (OECD, 2020). Magyarország egészségügyi kiadásokra a GDP 7,4\%-át fordította, amely szintén a 9,9\%-os európai uniós átlag alatti volt (EurópaiBizottság, 2017, Eurostat, 2019).

Az egészségügyi szükségletek hazánkban hasonlók a fejlett országokéhoz, de ezeket a szükségleteket a magas egy före jutó jövedelmü országokban rendelkezésre álló összegeknél sokkal alacsonyabb összegekből kell valahogy finanszírozni. Ha emellett még a jelentősen rövidebb hazai születéskor várható élettartamot, illetve az egészségesen töltött életévek számát is közelíteni szeretnénk a fejlett országok szintjéhez, akkor a hazai egészségügy erőforrás igénye valószínüleg meghaladja a fejlett országokét. Magyarországon a várható élettartam 76,2 év volt 2018-ban, az egészségesen várható élettartam pedig 61,1 év (Eurostat, 2018b, Eurostat, 2018a). Németországban 81,0 év, Ausztriában 81,8 év volt a várható élettartam, az egészségesen várható élettartam pedig rendre 65,8 év és 56.9 év volt 2018-ban (Eurostat, 2018b, Eurostat, 2018a).

Az állami finanszírozás mellett a betegek saját részesedése a költségek viselésében szintén emelkedő, és egyre jelentősebb. Az „out of pocket payment” Magyarország esetében rendkívül magas: 29\%-át teszi ki a kiadásoknak, az Európai Uniós 15\%-os átlagot jelentős mértékben meghaladva (EurópaiBizottság, 2017).

A krónikus megbetegedések közgazdaságtana egészségpolitikai, népegészségügyi forrásallokációs, és finanszírozási szempontból kiemelten fontos kérdés, hiszen ezek betegségterhe, költségei nem csak egyéni, családi, hanem társadalmi szinten is jelentős és folyamatosan egyre növekvő mértékűek. A fenntartható finanszírozás az egészségügyben és az ehhez szükséges optimális forrásallokáció megteremtésének szempontjából a költségek és az outcome-ok (eredmények, kimenetek) ismerete, betegségteher vizsgálata a terápiák költség-hatékonyságának elemzése nélkülözhetetlen információkat jelent a finanszírozó és egészségpolitikai döntéshozó számára. 
Az egyes krónikus betegségek esetében a különböző költségek azonosítása és mérése, valamint a terápia nélküli és a terápiás kimenet, eredmény elemzése, ide tartozik a betegek (és a családtagok, gondozók) életminőségének vizsgálata is, jelentősen hozzájárul a betegségteher felméréséhez, amely megalapozza az egészségpolitikai és finanszírozói döntéseket. Hazánkban a finanszírozó, korábban az Országos Egészségbiztosítási Pénztár (OEP), jelenleg a Nemzeti Egészségbiztosítási Alapkezelő (NEAK) adatbázisaiból ilyen adatok nem állnak rendelkezésre.

Az egészségügyi közgazdaságtani elemzések jelentősége, más fejlett országokhoz hasonlóan, hazánkban is nagy és folyamatosan növekvő. Ennek oka az, hogy az egészségügy költségvetésének egyre nagyobb részét, törvényi előírásoknak megfelelően, az egészségügyi közgazdaságtani elemzések eredményeinek a figyelembevételével is allokálják (Gulácsi et al., 2014b).

A legfontosabb módszerek a költségszámítás, a betegség-teher, a költség-hatékonysági és a költségvetési hatás elemzések.

Ezekhez a számításokhoz valid, standardizált, időről időre aktualizált és elérhető költségadatok (egységköltségek) és outcome információk szükségesek. Nagyon lényeges az, hogy az elemzések, egészségügyi közgazdaságtani számítások során, ezek az adatok minden esetben azonos módon kerüljenek felhasználásra, függetlenül attól, hogy ezek a verseny- vagy az állami szférában készülnek (gyógyszerforgalmazók, illetve AEK), hiszen az eredmények csak ebben az esetben hasonlíthatók össze.

Az egészségügyi forrás-allokációs döntések esetén, költségvetési hatások, költséghatékonysági eredmények kerülnek összehasonlításra, haszon-áldozat költségeket vizsgálunk, ennek megfelelően az adatok felhasználhatósága az összehasonlíthatósági követelmények teljesülése nélkül erősen limitált.

Ilyen egységköltség például a háziorvoshoz fordulás költsége, a mentőszolgálat 1 km-re eső költsége, az informális ellátás 1 órájára eső költsége, egy átlagos kórházi felvétel költsége, a munkából való kiesés, illetve a munkában töltött idő alatti, betegség miatti munkakapacitás csökkenés költsége. A költség-hatékonysági számításokhoz gyakran szükséges olyan költségek ismerete, amely valamely betegséggel kapcsolatos, amelyet az adott gyógyszer alkalmazásának eredményeképpen részben vagy egészében elkerülhető. Ehhez szükséges ismernünk például az egy kórházi felvételre (vagy egy évre) vonatkozó stroke, szívinfarktus, reumatoid artritisz és más betegség költségeit hazánkban. 
Az adott országra vonatkozó költségeket és egységköltségeket összefoglalóan tartalmazó adatbázis (amelyet Magyarországi egészségügyi online költség katalógusnak nevezünk) hiánya, ahogyan ezt hazánkban is láthatjuk, többek között nagyban megnehezíti a költségszámítás módszereinek egységesítését és hozzájárul, ahhoz, hogy a különböző elemzések során eltérő egységköltségekkel számolnak, valamint egyes elemzések eredményeinek vizsgálata során nem is állapítható meg egyértelmúen, hogy milyen egységköltségek felhasználásával történt a költségszámítás, illetve az egészségügyi közgazdaságtani elemzés. Emiatt az eredmények validitása ismeretlen, az összehasonlíthatóság pedig nagyon bizonytalan. Az összehasonlíthatóság is nagyon lényeges, hiszen az egészségügyi finanszírozási prioritási listákhoz, egészségpolitikai döntésekhez szükséges a pontos költségadatok ismerete.

Egyik fontos terület az alkalmazott új terápiák társadalombiztosítási rendszerbe történő befogadása (finanszírozásához), amely során feltétlenül fontos felmérni, hogy az adott egészségügyi technológia (megelőzés, szürés, diagnosztika, terápia) milyen költségekkel jár, illetve, hogy használata potenciálisan milyen hasznot eredményezhet.

Valamennyi Európai (és más fejlett országban) jogszabály által előírt az egészségpolitikai és finanszírozási döntések meghozatalát megelőző költséghatékonysági és költségvetésihatás vizsgálatok folytatása. Az egészségpolitikai döntések során a költség-hatékonysági szempontok kötelező figyelembevételét Magyarországon is rendelet (7/2016. (III. 30.) EMMI rendelet) szabályozza: „a biztonságos és gazdaságos gyógyszer- és gyógyászatisegédeszköz-ellátás, valamint a gyógyszerforgalmazás általános szabályairól” (EMMI, 2017). Az elemzésekhez helyi költéség adatokat szükséges figyelembe venni, más országokból származó költség-adatok hazánkba nem transzferálhatók, az egység költségek, az egészségügyi finanszírozás, illetve az egészségügyi gyakorlat igen jelentős különbségei miatt (Brodszky et al., 2019).

A betegségköltség (cost-of-illness - COI) kutatások egy adott betegség gazdasági terhéről nyújtanak információt, egyéni, finanszírozói vagy társadalmi nézőpontból. Céljuk nem csak a betegség kapcsán felmerülő egészségügyi költségek felderítése, hanem a teljes társadalmi teher meghatározása, beleértve az egészségügyi és nem egészségügyi költségeket, ezáltal segítve az adott egészségügyi probléma jelentőségének megértését és a legfontosabb költségtételek beazonosítását, valamint a költségstruktúra megismerését (Drummond et al., 2005). Ennek köszönhetően a betegségköltség felmérések rendkívül 
jelentősek és hozzájárulnak a finanszírozási és döntéshozó folyamatok támogatásához (Boncz et al., 2006). Az elmúlt évtized során a régió országaiban a HTA szerepének növekedése még inkább szükségessé teszi a megbízható, helyi (ország-specifikus) költségadatok használatát (Gulácsi et al., 2014b, Feig et al., 2017, Boncz et al., 2006).

A betegség költségek számításának nincsen egységesen elfogadott standardja (Larg et al., 2011, Jacobs et al., 2005). Amellett, hogy az eltérő módszertanok összehangolása egyre fontosabb célkitüzéssé válik, az összehasonlíthatóság megteremtése érdekében; jelenleg az eltérő kutatások sok esetben eltérő felépítést, módszertant, perspektívát és költségszámítási megközelítést alkalmaznak (Angelis et al., 2015, Onukwugha et al., 2016).

A krónikus betegségek esetében nem csak a közvetlen egészségügyi költségek jelenléte, hanem a direkt nem egészségügyi és az indirekt költségek is jelentős társadalmi terhet jelenthetnek. Korábbi kutatások eredményei is azt mutatják, hogy számos krónikus betegségben az informális ellátás a beteg ápolásának legnagyobb részét kitevő tényező. A jelenlegi demográfiai trendek mellett számítani kell arra, az informális ellátás igénybevétele egyre gyakrabban előforduló esemény lesz (Zrubka, 2017). Az informális ellátás a betegek, gondozásra szorulók egészségügyi és szociális ellátás formális, államilag finanszírozott keretein kívüli, a társadalombiztosítás által nem térített gondozását jelenti. Ennek során a betegek a családtagoktól, a velük egy háztartásban élőktől, barátoktól, szomszédoktól, segítő szervezetektől segítséget kapnak a napi teendőik ellátásához (öltözködés, tisztálkodás, étkezés, házimunka), a segítők bevásárolnak, kiváltják a recepteket, illetve más ügyeket intéznek, elkísérik a beteget az egészségügyi intézményekbe. Akut állapotokban is előfordulhat, hogy a családtagok által nyújtott segítség szükségessé válik (szülés, mütétek utáni időszakok), azonban krónikus megbetegedésekben még ennél is fontosabb lehet a tartós informális segítségnyújtás. Az informális ellátás sok segítő (informális ellátó), jelentős idejét veszi igénybe, sokan ráadásul emiatt sokan kiesnek vagy mulasztanak a munkából, mindezek miatt az informális ellátás napjainkban egyre fontosabbá váló terület (Gulácsi et al., 2012, Beretzky et al., 2017, Zemplenyi et al., 2016). Az informális ellátás emellett negatív hatással lehet az informális gondozók egészségi állapotára és életminőségére, valamint jelentős költségeket vonhat maga után (Krol et al., 2015). Az informális ellátásra fordított időt, és az azzal kapcsolatosan felmerülő terheket a betegséggel összefüggő költségnek 
tekinthető, amennyiben feltételezzük, hogy ennek hiányában ezt a gondozási tevékenységet formális egészségügyi, szociális ellátással lenne szükséges helyettesíteni.

Az informális ellátás azonban sok esetben lehet alul értékelt, ha annak költségeit figyelmen kívül hagyják az egészségügyi beavatkozások gazdasági értékelése során (Krol et al., 2015), ezért az informális ellátás bevonása a krónikus betegségek egészséggazdaságtani elemzéseibe befolyásolhatja azok eredményeit és hozzájárulhat a szakpolitikai döntéshozatal során optimálisabb döntések meghozatalához (van den Berg et al., 2004). Az informális ellátás igénybevétele számos tényezőtől függ, úgymint a társadalom szocio-demográfiai összetétele, ezért ország-specifikus adatok ismerete mellett átfogóbb képet kapunk a betegséggel összefüggő terhekről.

Krónikus, hosszan akár több évtizeden át is tartó megbetegedésekben még fontosabb informális ellátás. Fontos ennek a szerepe az idősödő társadalmak esetén, hiszen mivel a várható élettartam jelentősen növekedett és növekszik, az emberek egyre hosszabban élnek, hosszabb időt töltenek kisebb vagy nagyobb mértékben csökkent önellátási képességgel, ezért mások segítségére szorulnak átmenetileg vagy tartósan (Verbakel et al., 2017), 2015-ben az EU28-tagállamok lakossága körében a 65 év felettiek aránya 18,9\% volt, míg hazánkban 17,9\% (Eurostat). A „baby-boomer” korosztályok öregedése is jelentősen növeli a gondozási szükségleteket.

Az informális ellátás igénye azonban nem csak az idős korosztályra korlátozódik. Egyre nagyobb számú gyerek és fiatal felnőtt él súlyos krónikus megbetegedéssel, és igényel informális ellátást. Ilyenek például az úgynevezett ritka betegségek, amelyek esetén a betegek száma egy-egy megbetegedésben nem magas, de a több mint ezer ritka betegségeben több százezer beteg érintett (Cavazza et al., 2016b, Kuhlmann et al., 2016, Iskrov et al., 2016, Lopez-Bastida et al., 2016a, Péntek et al., 2016c, Cavazza et al., 2016a). Az egyre hatékonyabb orvosi technológiák alkalmazásának eredményeképpen a fejlett országokban, így hazánkban is, jelentősen emelkedik a krónikus megbetegedésekkel élők várható élettartama és száma. Jól megfigyelhető ez a tendencia az Európai országokban is, ahol jelentősen emelkedett az aktivitást korlátozó krónikus betegségek előfordulási gyakorisága. Ezek közül is kiemelhetők a demencia, a csontritkulás, a szív- és érrendszeri megbetegedések, valamint a daganatos betegségek. 
Napjainkban, a krónikus betegségben szenvedők esetén az informális ellátás költsége jelentős, az esetek jelentős részében meghaladja a direkt egészségügyi költségeket (Hoefman et al., 2013, Eurostat). Ezek a költségek az Amerikai Egyesült Államokban már évtizedek óta meghaladják a biztosítás és állam által finanszírozott egészségügyi szektor költségeit (Arno et al., 1999). Az informális ellátás bizonyos mértékben helyettesítheti a biztosítás, illetve állam által finanszírozott egészségügyi/szociális ellátást, ezáltal csökkentheti ezeket az egészségügyi kiadásokat (Bremer et al., 2015, Boncz et al., 2006). Lényeges szempont azonban az is, hogy az informális gondozók egészsége esetenként romlik és a munkaképessége csökken (Colombo et al., 2011). A jelenleg megfigyelhető demográfiai trendek további fennállása mellett elöre jelezhető, hogy az informális ellátás iránti szükséglet és az emiatt felmerülő költségek a továbbiakban is jelentősen nőni fognak (Vlachantoni et al., 2013, KSH, 2013).

A krónikus betegségekben felmerülő betegségteher egyre növekvő mértékü, hiszen ezek az állapotok az egészség és az egészséggel összefüggő életminőség csökkenésének legfőbb okozói, amellett az egészségügyi kiadások jelentő része is ezeknek tulajdonítható (Bauer et al., 2014). Az egészséggel összefüggő életminőség mérése a krónikus betegségekben segít az adott terápia hatékonyságának megítélésében és információt biztosít a lehetséges egészségnyereségekről. Ezek az információk hozzájárulhatnak a forrásallokáció optimalizálásához és elősegíthetik a döntéshozatalt.

$\mathrm{Az}$ életminőség multidimenzionális fogalom melynek egy területe az egészséggel összefüggő életminőség. Számos olyan betegség létezik, mely nem az élettartamot befolyásolja jelentősen, hanem a beteg életminőségére gyakorol negatív hatást. A betegségek kezelésére hivatott terápiák is sok esetben az életminőségre gyakorolnak hatást, és ennek mérése nélkül valódi hasznuk nem megállapítható. Az egészséggel összefüggő életminőség mérése hozzájárul a szükségletek meghatározására, az egészségi állapotok leírására és segíti például a különböző terápiák közötti választásokat, ezáltal hozzájárul a források hatékony allokációjának kialakításához. Napjainkban egyre hangsúlyosabb szerepet kaphat az életminőség mérése, hiszen a lakosság egyre nagyobb része él együtt krónikus betegségekkel, egyre hosszabb ideig, ezért a népegészségügyi programok is egyre nagyobb figyelmet fordítanak az élet minőségére.

A kutatási területet kiemelt közpolitikai közfinanszírozási jelentőséggel rendelkezik. Egy országon belül a lakosság eltérő demográfiai és társadalmi-gazdasági jellemzőkkel 
leírható csoportjai eltérő egészségügyi szükségletekkel rendelkeznek és eltérő egészségügyi ellátásban részesülhetnek, ezek felmérése jelentős kérdés. Szintén vizsgálandó, hogy ez egészségügyi ellátásoknak milyenek haszna van és költség-tényezői vannak, valamint, hogy ezeket a költségeket milyen arányban állja az egyén.

Stiglitz kiemeli az állami beavatkozás jelentőségét az egészségügy területén. Az egészségügyi politikák célja olyan egészségügyi rendszer kialakítása, amely egészségi állapot-orientált, az egészségre ható társadalmi-gazdasági tényezők, és kockázati tényezők befolyásolására, esélyegyenlőségre törekszik, hatékony, finanszírozható, és törekszik arra, hogy a rendelkezésre álló szűkös erőforrásokkal a lehető legnagyobb egészségi állapot javulást lehessen elérni, valamint választási lehetőséget biztosít az egyének számára (Stiglitz, 2000). Az egészségügy területén számos piaci kudarc megjelenik, amelyek jelenléte szintén igazolja az állami beavatkozás szükségességét: a közjavak problémája, externáliák, információs aszimmetria, korlátozott verseny és a javak meritórikus jellege (Stiglitz, 2000).

$\mathrm{Az}$ információs aszimmetria jelentős az egészségügy területén, az egészségügyi szolgáltatást igénybe vevőknek az orvos és más egészségügyi szakember tudására és döntéseire kell hagyatkoznia. Azonban az orvos sem rendelkezik minden területen teljes körü információval, tudatában van például a beteg laboratóriumi vizsgálatának eredményeinek, azonban nem feltétlenül ismeri a beteg általános egészségét életminőségét, jólléti képességét vagy ezek társadalmi képességire, való hatását.

$\mathrm{Az}$ információs aszimmetria csökkentését nehezíti, hogy nehéz a szolgáltatások összehasonlítása (költség, minőség, hatékonyság) is. Az egészségügyi szektorban ez az összehasonlítás nem megvalósítható, hiszen túl sok eltérő beavatkozás, kórház és orvos van jelen, egy kórház például bizonyos beavatkozások elvégzésében kiváló, más beavatkozáséban gyenge lehet (Stiglitz, 2000).

Ráadásul a kórházak közötti verseny is korlátozott, ettől sem várható, hogy a jó és hatékony szolgáltatók verseny előnybe kerülve kiszorítsák a gyengébbeket. A legtöbb akár nagy - településen is csak egy kórház müködik (Stiglitz, 2000). „A beteg az orvos ítéletére hagyatkozik, hogy milyen gyógyszert célszerü szednie, hogy tanácsos-e oprációnak alávetnie magát és így tovább” (Stiglitz, 2000, p315.).

Ahogy Stiglitz megfogalmazza: „A nem-tökéletes információk miatt a verseny effektív szintje csökken”. „Az orvosi szolgáltatások heterogenitása ugyanakkor igen nehézkessé 
teszi az árbeli és minőségi összehasonlításokat, ezért sem kedvez az információ effektív terjedésének.” (Stiglitz, 2000, p316.) és „Az orvosi szakma gyakorlata alighanem összhangban van azzal, hogy a nem-tökéletes információk miatt a verseny óhatatlanul korlátozott.” (Stiglitz, 2000, p316.). Stiglitz szintén felhívja a figyelmet arra, hogy: „A kórházak többsége nem profitorientált intézmény” (Stiglitz, 2000, p316.).

Napjainkban a kormányzatok és biztosítók éppen emiatt nem csak ezt (minőség, költség) igyekeznek mérni, hanem azt is, hogy a beteg milyen állapotban volt a kórházba felvétel és a kórház elhagyásának idejében (generikus és betegség-specifikus mércék által).

A finanszírozók egyre inkább nem egészségügyi szolgáltatások, hanem "eredményt" szeretnének “venni”, ami az egészségnyereségként kifejezhető.

A döntéshozatal részben az orvosok feladata, de az egészség nyereségről számot is kell adniuk. Részben az adott ország finanszírozója hozza a döntést, azáltal, hogy meghatározza, hogy mit más hogyan finanszíroz.

Figyelemre méltó, hogy a túlzott egészségügyi kiadás nem megfelelő lehet, kárt is okozhat. Egy kutatás eredményei azt mutatták, hogy annak a valószínüsége, hogy egy gyermek mandulája eltávolításra került 7 és 70\% között mozgott Vermontban, az Egyesült Államokban. Ez a túlkezelésnek nevezett jelenség hazánkra is jellemző, egyik következménye az információs aszimmetriának, erre az OECD is több ízben felhívta a figyelmet országjelentésében (OECD, 2019).

Az egészségügyi finanszírozás két legjelentősebb eleme a forrásteremtés és a forrásallokáció, vagyis, hogy milyen mechanizmusokon, módszereken keresztül történik a források felhasználása (Stiglitz, 2000). A közfinanszírozott ellátó rendszer fennállása mellett jelentős kérdés, hogy az egészségügyi szolgáltatásokat hogyan finanszírozza a (finanszírozó) állam, azaz a 'köz', és annak tagjai, akik az egészségügyi rendszert befizetéseikkel fenntartják.

Magyarországon jelenleg az egészségüggyel kapcsolatban rövid és hosszútávú közpolitikai közfinanszírozási döntésekhez nem kerül rutinszerüen gyüjtésre és nem áll rendelkezésre megfelelő minőségü és mennyiségü adat.

A dolgozat különböző egészség egészséggazdaságtani kutatások eredményeiről számol be, ennek megfelelően jellemzője a jelentős módszertani heterogenitás, hiszen a különböző kutatások sokszor nagyon eltérő módszertan alkalmazását igénylik. 
A dolgozat felépítése az alábbiak szerit alakul:

A dolgozat 4. fejezetétől kezdődően az egyes fejezetekben a számozás második pozíciójában (helyi értéken) álló tagja jelöli egy-egy nagyobb kutatáskör leírását. Ennek megfelelően az 4. fejezettől kezdődően az 4.1, 5.1, 6.1, és 7.1 alfejezetek azonos kutatásoknak mutatja be a célkitűzéseit, módszertanát, eredményeit és megbeszéléseit.

A fejezetszámozás második pozíciójában szereplő „,1.” jelöléssel rendelkező alfejezetek az életminőség méréssel kapcsolatos kutatásokat tárgyalják. A harmadik helyi értéken álló számmal jelölt alfejezetek pedig az életminőség-mérés témakörbe tartozó egyes kutatásokat jelöli. Különböző országok EQ-5D kérdőív értékkészletének összehasonlítását (1) ${ }^{1}$ (Zrubka et al., 2019), egy betegségspecifikus kérdőíves vizsgálat (DLQI) elemzését $(2)^{2}$ (Rencz et al., 2018), valamint egy keresztmetszeti vizsgálat eredményei alapján a magyarországi lakosság egészségi állapota és munkaképességének jellemzését (3) (Péntek et al., 2020)³ , és az informális ellátás és meghatározó tényezőinek felderítését krónikus betegségekben (4) (Beretzky et al., 2017) ${ }^{4}$.

A fejezetszámozás második pozíciójában „2.” jelöléssel ellátott alfejezetek témája a költségszámítás az egészségügyben; ebben az alfejezetben is további kutatások szerepelnek, amelyeket a fejezetszámozás harmadik helyi értékén található számokkal különítettünk el: az informális ellátás költségeinek mérése (1) (Beretzky) ${ }^{5}$, a régióban készült publikációkban szereplö betegségköltség (cost of illness) adatok elemzése (2)

\footnotetext{
${ }^{1}$ A megfelelő alfejezetek az alábbi publikáción alapulnak: Zrubka Zs, Beretzky Zs, Hermann Z, Brodszky V, Gulácsi, L, Rencz, F, Baji P, Golicki D, Prevolnik-Rupel V, Péntek M (2019): A comparison of European, Polish, Slovenian and British EQ-5D-3L value sets using a Hungarian sample of 18 chronic diseases. European Journal of Health Economics 20, Suppl. 1, pp. 119-132.

${ }^{2}$ A megfelelő alfejezetek az alábbi publikáción alapulnak: Rencz F, Poór AK, Péntek M, Holló P, Kárpáti S, Gulácsi L, Szegedi A, Reményik É, Hidvégi B, Herszényi K, Jókai H, Beretzky Zs, Brodszky V (2018): A detailed analysis of 'not relevant' responses on the DLQI in psoriasis: potential biases in treatment decisions. Journal of The European Academy of Dermatology and Venereology, 32, 5, pp. 783-790.

${ }^{3}$ Péntek M, Beretzky Zs, Brodszky V, Szabó, A. Kovács, L. Kincses, Á. Baji P, Zrubka Zs, Rencz F, Gulácsi L: A magyarországi lakosság egészséggel összefüggő munkaképessége: keresztmetszeti reprezentatív felmérés a Munkaképességre és Tevékenységcsökkenésre vonatkozó kérdőívvel. Orvosi Hetilap, publikációra elfogadott

${ }^{4}$ A megfelelő alfejezetek az alábbi publikáción alapulnak: Beretzky Zs, Péntek M (2017): Informális ellátás és meghatározó tényezői krónikus betegségekben: magyarországi kutatások összehasonlító elemzése [Characteristics and determinants of informal care in chronic diseases in Hungary: a comparative analysis] Orvosi Hetilap, 158, 52, pp. 2068-2078.

${ }^{5}$ A megfelelő alfejezetek az alábbi publikáción alapulnak: Beretzky Zs: Az informális ellátás költsége krónikus betegségekben: magyarországi kutatások összehasonlító elemzése. Köz-Gazdaság, publikálációra elfogadott
} 
(Brodszky et al., 2019) ${ }^{6}$, valamint a Magyarországi egészségügyi online költség katalógus kialakításának kérdése (3).

A dolgozatban szereplő terület összefüggéseit és felépítését az 1. Ábrán foglaljuk össze. (1. Ábra)

${ }^{6}$ A megfelelő alfejezetek az alábbi publikáción alapulnak: Brodszky V, Beretzky Zs, Baji P, Rencz F, Péntek M, Rotar A, Tachkov K, Mayer S, Simon J, Niewada M, Hren R, Gulácsi L (2019): Cost-of-illness studies in nine Central and Eastern European countries. In: European Journal of Health Economics, 20, Suppl1, pp. 155-172. 
1. Ábra A dolgozatban ismertetett kutatások összefüggései

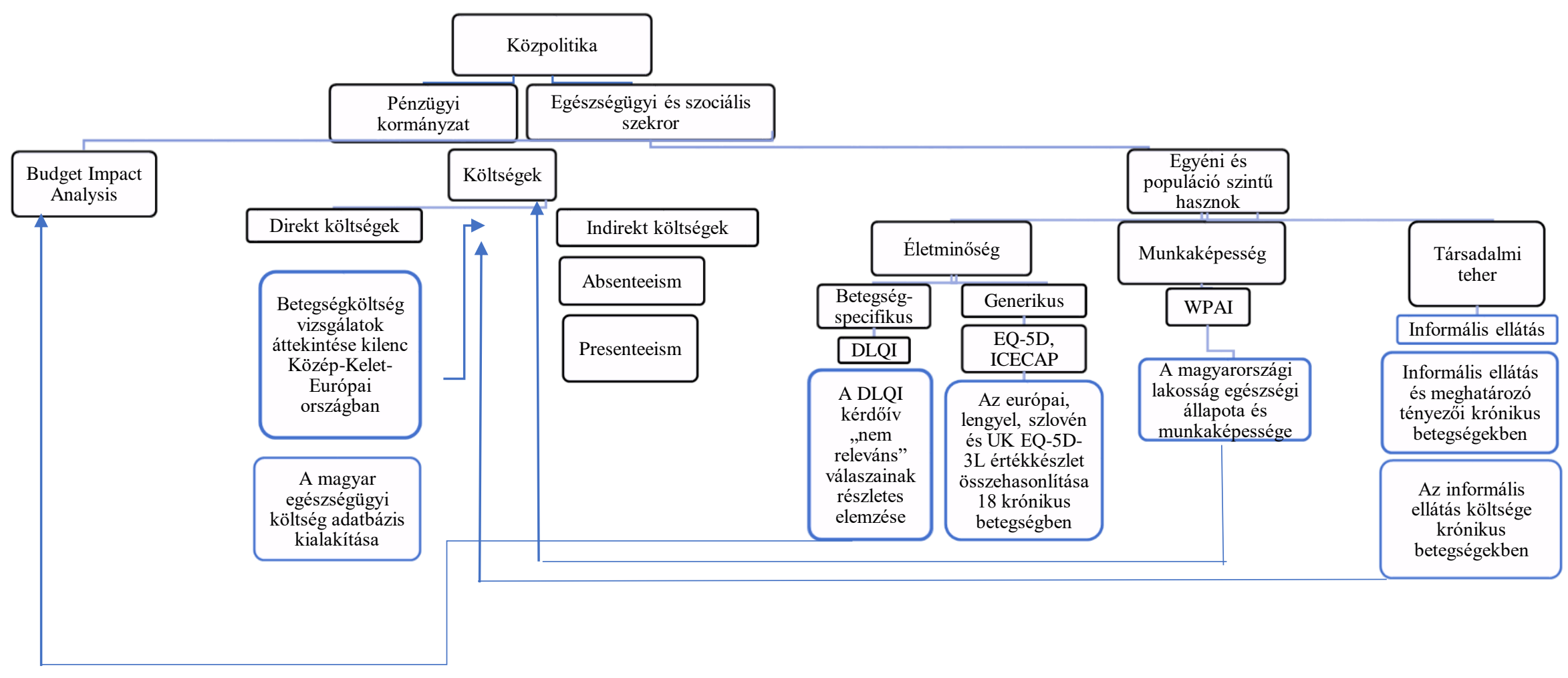




\section{ELMÉLETI ALAPOK}

Ebben a fejezetben a dolgozatban alkalmazott és tervezett kutatások legfontosabb elméleti koncepcióit, módszertani hátterét foglalom össze.

Kutatásaink során egyrészt a megbetegedések által okozott életminőség csökkenést és költségeket vizsgáltuk, másrészt a terápiák eredményeként elérhető egészségnyereséget (betegség specifikus és generikus mércék), költséghatékonyságot és költségvetési hatást elemeztük. Az életminőség csökkenés (és ennek következményei, társadalmi hatása) a betegség által okozott betegségteher, amely, legalábbis részben elkerülhető megfelelő terápiák alkalmazásával. Mindezek együttesen szükségesek az egészségügyi közgazdaságtani elemzésekhez. Mivel szükségszerüen különböző elméleti koncepciók és módszertanok kerültek alkalmazásra, ez módszertani heterogenitásnak is tünhet, holott ezek teljes köre szükséges a vizsgálatokhoz.

Az alábbi fejezetben ezen vizsgálatok és eszközeik elméletei alapjai kerülnek bemutatásra.

\section{1. Életminőség mérés}

A betegségek következményeinek és a terápiák hasznának értékelése során az élettartam mellett az életminőségre gyakorolt hatás a legfontosabb értékelési szempont. Az életminőséget számos tényező befolyásolja, jelen esetben az egészségi állapottal összefüggő életminőség tárgyalására és kutatására fókuszálunk.

Az egészséggel kapcsolatos életminőség mérésére általános és betegségspecifikus mércék használatosak.

A következőkben bemutatásra kerül a világon a legelterjedtebben használt, legtöbb nyelven elérhető generikus életminőség mérce az EQ-5D kérdőív, 
valamint egy a bőrgyógyászat területén használatos betegségspecifikus életminőség kérdőív: a bőrgyógyászati életminőség index (DLQI).

A generikus mércék lehetővé teszik az életminőség változásainak összehasonlítását a legkülönbözőbb betegségek között, illetve a jelen fejezetben ismertetett módon költség-hasznosság kalkulálására alkalmasak, ezért az eredmények hasznosak az egészségpolitikai döntéshozók és a finanszírozók számára is.

A betegség specifikus mércék a betegség súlyosság mérésére és a terápia hatásának a monitorozására alkalmas, ennek megfelelően a klinikumban kerül alkalmazásra. Ezen mércék eredményeit használják (sokszor nagy értékü) terápiák indikációjának megállapítására (mikor kaphatja a beteg a terápiát). Ezért ezek az orvosi döntések egyben forrás allokációs döntések is (hiszen az orvos indikációs döntéseivel közpénzt utalványoz a társadalombiztosítási alapból) így ezeknek is nagy az egészségügyi közgazdaságtani jelentősége.

\subsubsection{Az EQ-5D kérdőív}

A leggyakrabban alkalmazott generikus életminőség mérce az EQ-5D. (Brazier et al., 2019) Az EQ-5D-3L az egészség öt dimenziójában (mozgékonyság, önellátás, szokásos tevékenységek, fájdalom/rossz közérzet, szorongás/lehangoltság) a pillanatnyi egészségi problémák 3 szintjét méri (1: nincs, 2: enyhe, 3: súlyos), ezáltal 243 (minden dimenzióban 3 lehetőség, azaz $3^{5}$ ) diszkrét egészségi állapotot ír le. Az egyes egészségi állapotokat az egyes dimenziókban jelzett problémák szintje alapján ötjegyü számmal jelezzük: ezeket EQ-5D profilnak nevezünk. A '21112' EQ-5D profil például az enyhe mozgászavarral és enyhe szorongással járó egészségi állapotot jelöli (EuroQolGroup, 1990). Létezik öt problémaszintet mérö, ezáltal $3125\left(3^{7}\right)$ egészségi állapotot leíró verzió is, az EQ-5D-5L (Herdman et al., 2011). Az EQ5D kérdőívnek szintén része az EQ VAS, melyen a vizsgált egyén a kitöltés idejében megtapasztalt állapotát az elképzelhető legrosszabb (0) és legjobb (100) egészség között jelöli be. Az egyes EQ-5D állapotokhoz a hasznossági értékek 
különböző módszerekkel határozhatóak meg (standard játszma (standard gamble, SG), időalku (Time Trade-Off, TTO), vizuális analóg skála (VAS) vagy a diszkrét választások módszerével (discrete choice experiment, DCE)). Az EQ-5D-3L hasznossági értékek értékkészletek segítségével határozhatók meg. Számos ország rendelkezik saját értékkészlettel, hiszen ezek országspecifikusak és a helyi sajátosságok figyelembevételével kerültek kialakításra. Korábbi kutatások eredményei arra utalnak, hogy az eltérő értékkészletekkel meghatározott eredmények eltérései szociális és kulturális különbségekre vezethetők vissza. Az EQ-5D kérdőívben megjelenített problémák relatív jelentősége eltér a különböző értékkészletekben, és eltérő állapotokban az EQ-5D eltérő dimenziói érintettek nagyobb mértékben. Kutatásainkban az értékeléshez az Egyesült Királyság hasznosság értékkészlete került felhasználásra (Devlin et al., 2017), mivel magyar tarifa a jelen dolgozatban ismertetett kutatások idején még nem állt rendelkezésre és lakossági felmérésekben is ezt alkalmazták (Baji et al., 2015). Az Egészségügyi Közgazdaságtan Tanszék számos korábbi kutatásában megjelent az EQ-5D kérdőív használata, így a Tanszéken jelentős kutatási tapasztalat halmozódott fel ezzel kapcsolatosan (Péntek et al., 2014, Pentek et al., 2013, Péntek et al., 2012c, Péntek et al., 2012a, Péntek et al., 2016c, Péntek et al., 2007, Rencz et al., 2014, Rencz et al., 2015c, Balogh et al., 2013, Bernert et al., 2009, Brodszky et al., 2009, Brodszky et al., 2010d, Batog et al., 2018).

\subsubsection{Hasznosságmérés}

Az egészség-gazdaságtani elemzésekben valamely specifikus egészségi állapot vagy kimenet preferáltságának mérésére a hasznosság (utility) használt. A teljes egészség hasznossága 1-nek tekintendő, a 0 hasznosság érték pedig a halál állapotához társítható. Negatív hasznosság értékkel a „halálnál rosszabb” állapotok rendelkeznek. A hasznosság mérése direkt és indirekt módszerek segítségével történhet. Direkt módszerek a standard játszma (SG), a vizuális analóg skála (VAS) és a time tarde-off (TTO). Az indirekt hasznosságmérés eszközei pedig pl. EQ-5D vagy a Short-Form 6D (SF-6D) kérdőív. 


\subsubsection{Betegségspecifikus kérdőívek: a bőrgyógyászati életminőség index}

$\mathrm{Az}$ életminőség mérése nem csak általános, hanem betegségspecifikus kérdőívekkel is történhet. A börgyógyászati életminőség index (Dermatology Life Quality Index - DLQI) kérdőív 10 elemü és minden kérdésén 0 és 3 közötti ponttal jellemezhető aszerint alapján, hogy a börprobléma mennyire befolyásolták a beteg életminőségét a kitöltést megelőző héten (Basra et al., 2008). A 10 elemből álló kérdőív az egészséggel összefüggő életminőség hat területét fedi le: tünetek, mindennapi tevékenység, szabadidő, munka és oktatás, személyes kapcsolatok és kezelés. Minden kérdés egy négy fokozatú skálán

pontozott ( $0=$ =egyáltalán nem", 1="kissé", 2="meglehetősen", 3="nagyon"). Ezen felül nyolc kérdés esetében a kitöltőnek van lehetősége „nem vonatkozik Önre" ('not relevant resonse' - NRR) válaszlehetőséget megjelölni, amely az „egyáltalán nem” válaszokhoz hasonlóan 0 értékkel rendelkezik. Az egyes elemek összegzett pontszáma 0 és 30 közötti értéket vehet fel, ahol a nagyobb érték nagyobb mértékủ életminőség romlással társítható (Basra et al., 2008).

A NRR válaszlehetőség a kérdések 80\%-ban való megjelenése szokatlan egy rövid kérdőív esetében, azonban ezek vizsgálata az irodalomban ritka és inkonzisztens. A DLQI kutatások többsége nem jelenti a NRR válaszok előfordulásának gyakoriságát, azonban több országból származó kutatások jelentettek nagyszámú vagy szinte egyáltalán nem előforduló NRR válaszokat (Ferraz et al., 2006, Hahn et al., 2001, Herédi et al., 2014).

\subsubsection{Az életminőséggel súlyozott életév koncepció bemutatása}

Ez egészségkimenetek mérésének leggyakrabban alkalmazott mérőszáma az életminőséggel súlyozott életév (Quality Adjusted Life Year, QALY) (Rios-Diaz et al., 2016). A QALY az élet hosszát és az életminőséget egy hasznosság egyaránt kifejezi. A teljes egészség állapotát 1, a halál állapotát 0 jelöli.

A halálnál rosszabbnak ítélt egészségi állapotok negatív számokkal kerülnek leírásra. A QALY nem alkalmaz különbségeket el az egyes állapotok súlyossága 
vagy a vizsgált egyének eltéréseire vonatkozóan és nem különbözteti meg az élet hosszát és minőségét.

Egy teljes egészségben eltöltött évet egyenértékünek tekint tíz év 0,1 minőségben töltött állapottal. Ha az egészségi állapot javulását szeretnénk kifejezni, akkor megfigyelhetjük, hogy például 0,3-ről 0,5-re 30 éves korban, illetve 0,8-ról 1,0ra történő javulással 60 éves korban (Gulácsi et al., 2012).

Az egyes egészségi állapotokhoz a hasznosságértékeket a lakossági preferenciák mérésével rendelik. Ezek a hasznosságértékek meghatározása a lakosság vagy valamilyen betegcsoportok által, elképzelt vagy megélt egészségállapotok alapján történik (Brazier et al., 2018).

Az egészséggel összefüggő hasznosság direkt és indirekt módszerekkel is meghatározható. A direkt módszerek konkrét betegségleírások értékelésével, az indirekt módszerek pedig általános életminőség-kérdőívekkel leírható állapotok értékelésével határozzák meg a hasznosságot. A két módszerben közös, hogy egy konkrét állapot hasznosságát értékeli egy adott hasznosságértékkel (Brazier et al., 2019).

\subsubsection{Az egészségi állapot és jól-lét mérése}

Az életminőség mércék mellett számos más módon is jellemezhető egy adott beteg egészségi állapota és jól-léte. Az alábbiakban azok a kérdőívek és módszerek kerülnek röviden bemutatásra, amelyek szerepeltek kutatásunkban.

\subsubsection{Minimum European Health Module (MEHM)}

A Minimum European Health Module (MEHM) három általános kérdésből áll. A válaszadó értékeli a jelen egészségi állapotát egy öt fokozatú skálán (Nagyon jó / Jó / Kielégítő / Rossz / Nagyon rossz). Nyilatkozik arról, hogy van-e legalább 6 hónapja fennálló krónikus megbetegedése (Igen / Nem), valamint korlátozza-e legalább 6 hónapja fennálló egészségi probléma (súlyosan korlátozza / korlátozza, 
de nem súlyosan / nem korlátozza), ez utóbbi mérce az ún. Global Activity Limitation Indicator (GALI) (Eurostat, 2013, Eurostat, 2019).

\subsubsection{ICECAP-A és ICECAP-O kérdőív}

Az ICECAP-A (ICEpop CAPability measure for Adults) és az ICECAP-O (ICEpop CAPability measure for Older People) a képességek és a tapasztalt jóllét mérésére szolgáló eszközök. A mércék Amartya Sen megközelítésére támaszkodva lettek fejlesztve, amely az egyének jól-létét az egyéb életében fontos tevékenységek elvégzésének képességére alapozza. Mindkét kérdőív egészséggazdaságtani elemzésekben alkalmazható mérce. azonban az ICECAP a jól-lét egy tágabb értelmezését alkalmazza és nem csak az egészség dimenziójára fókuszál. Az ICECAP-A kérdőív öt fő területre fókuszál: Stabilitás és biztonságérzet, Szeretet, barátság és támogatás), Függetlenség, Eredmények és fejlődés, valamint Kellemes élmények és öröm. A kérdőív kitöltője területenként négy válaszlehetőség közül választhatja ki a helyzetét legjobban leíró állítást. Az ICECAP-O a Szeretet, barátság és támogatás, A jövőről való gondolkodás, Tevékenységek, amelyektől értékesnek érzi magát, Kellemes élmények és öröm és Függetlenség dimenziókban ad lehetőséget a négy válasz közötti választásra. Az ICECAP score 0 és 1 között mozoghat, amely skálán a 0 jelöli a képességek teljes hiányát (Al-Janabi et al., 2012) (Flynn et al., 2015, Al-Janabi et al., 2013).

\subsection{Költségszámítás}

A betegségteher felmérése, a betegségek és az egészségügyi ellátások költségeinek meghatározásának érekében a releváns erőforrások azonosítása, felhasználásuk mérése és ezek értékének meghatározása jelenti a költségszámítás alapját. A költségszámítás során jelentős választás a perspektíva kiválasztása. Az egyes betegségek betegségterhe, betegség-költsége, valamint a terápiák költségeire vonatkozó adatok azonosítása és rendszerezése kiemelten fontos napjainkban, hiszen egészségügyi közgazdaságtani elemzésekhez biztosít bemeneti adatokat. Az optimális egészségpolitikai döntésekhez és forrásallokáció kialakításához és a fenntartható finanszírozásra való törekvéshez szükséges az 
egyes betegségek, illetve terápiák költségeire vonatkozó részletes, országspecifikus költségadatok ismerete. A költségeket tankönyvi elkülönítés szerint direkt egészségügyi, direkt nem egészségügyi és indirekt költség kategóriákba sorolhatjuk.

\subsubsection{Direkt egészségügyi költségek}

Olyan erőforrások tartoznak ebbe a kategóriába, amelyek az egészségügyi beavatkozásokhoz közvetlenül szükségesek.

\subsubsection{Direkt nem-egészségügyi költségek}

A direkt egészségügyi költségekkel szemben ebbe a költségkategóriába olyan nem egészségügyi erőforrások tartoznak, amelyek az egészségügyi beavatkozásokhoz szükségesek. Fontos kiemelni, hogy a direkt nem egészségügyi költségek körébe tartoznak az informális ellátás költségei, az egészségügyi ellátás elérése érdekében történő utazás költségei vagy a beteg lakásának átalakítási költségei.

\subsubsection{Informális ellátás}

Az indirekt költségek magukban foglalják a beteg munkatermelékenységében bekövetkezett változásokat. Az informális ellátás a szervezett, társadalombiztosítás által finanszírozott rendszeren kívül, nem professzionális segítő által nyújtott segítségnyújtás jelenti. Az informális ellátás költségei egyes krónikus betegségek esetében a teljes költségek jelentős százalékát tehetik ki. Az informális ellátás igénye egyes betegségekben kifejezetten jelentős: korábbi kutatásunk eredménye az mutatta, hogy például a demenciában vagy Parkinson kórban szenvedő betegek heti szinten több, mint 12 óra informális ellátást vettek 
igénybe (Zrubka, 2017, Beretzky et al., 2017). Az informális ellátás szerepe egyre nagyobb (Zrubka, 2017, Beretzky et al., 2017), hiszen a formális (hivatalos, finanszírozott) egészségügyi ellátásnak nem célja a betegek teljese körü, hosszú távú gondozása, részben ennek költség vonzata miatt, részben pedig azért, mert a betegek az intézményi ellátás helyett a saját otthonukban, saját környezetükben történő tartózkodást és ellátást preferálják.

Az informális ellátás költségeinek becslése több módszer segítségével végezhető. Ezek közül leggyakrabban a piaci költségek módszere és a haszon-áldozat költségek módszere kerül alkalmazásra. Előbbi az informális szolgáltatás költségét a szolgáltatás piaci árával becsli. A haszon-áldozat költségek módszere pedig esetében az informális ellátást nyújtó személy bérével számolunk, amit abban az esetben realizálhatna, ha nem nyújtana informális szolgáltatást, hanem fizetett munkát vállalna (Zrubka, 2017, Beretzky et al., 2017, Gulácsi et al., 2012).

\subsubsection{Indirekt költségek}

Az indirekt költségekben jelennek meg a beteg ideje, és a termelékenység költség (productivity loss). A fizetett munkából való kimaradás vagy a munka során tapasztalt termelékenységcsökkenés költségeinek mérésére legfőképpen két módszer használata jellemző: az emberi tőke modell és a súrlódási költség modell.

\subsubsection{Absenteeism}

A munkából való, egészségi okok miatt távolmaradás (betegség miatt táppénz, betegség miatt felmerülő tartós távolmaradás, rokkantság) miatt felmerülő munkatermelékenység veszteséget fejezi ki az absenteeism.

\subsubsection{Presenteeism}

A betegek munka-teljesítmény csökkenése nem csak a munkából való távolmaradása, hanem a munka során, betegség által okozott termelékenységcsökkenés miatt is megjelenhet, amit a presenteeism fejez ki. 
2.2.3.3. A termelékenységköltség (productivity loss) mérése: Work Productivity and Activity Impairment (WPAI)

A termelékenység költség mérhető nemzetközileg validált standardizált kérdőív segítségével. A Work Productivity and Activity Impairment - General Health (WPAI-GH, továbbiakban: WPAI) egy kérdőív, amely a fizetett és nem fizetett munkában való egészségi problémák miatti (fizikai és mentális problémák vagy tünetek miatti) akadályozottság felmérésére szolgál. A kérdőív az absenteeism és presenteeism mérésére egyaránt alkalmas, továbbá a nem fizetett munka és egyéb tevekénységekben tapasztalt akadályozottságát is méri.

A kérdőív hat kérdésből áll. A válaszadóknak először azt kell megjelölnie, hogy végez-e jelenleg fizetett munkát (Q1). A következő szekció (Q2-Q5) csak azokra a résztvevők számára releváns, akik fizetett munkát végeznek. A munkából egészségi (Q2) valamint egyéb okok (Q3) miatt hiányzott órák száma megkérdezésre kerülnek. A válaszadóknak ezután azt kell megjelölnie, hogy valójában hány óra munkát végzett az elmúlt hét nap során (Q4). A munka közben tapasztalt munkatermelékenység veszteség mértékét egy 11 pontos skálán méri a kérdőív (0: nem befolyásolta, 10: teljes mértékben megakadályozta). Az utolsó kérdés (Q6) arra vonatkozik, hogy a válaszadó egészségi problémai milyen mértékben befolyásolták mindennapi tevékenységeit. Ez a kérdés is egy 11 pontos értékelési skálát alkalmaz (0: nem befolyásolta, 10: teljes mértékben megakadályozta).

A pontozás során az értékek 100-szorosának kiszámításával, százalékban kerülnek kifejezésre:

Abstenteeism: A munkából egészségi állapot miatti távollét: $\mathrm{Q} 2 /(\mathrm{Q} 2+\mathrm{Q} 4)$

Presenteeism: A munka során egészségi állapot miatt tapasztalt produktivitás csökkenés: Q5/10

\section{Összesített termelékenységveszteség munkavégzés közben (\%):}

Teljes munka produktivitás veszteség az egészségi állapot miatt:

$$
\mathrm{Q} 2 /(\mathrm{Q} 2+\mathrm{Q} 4)+[(1-(\mathrm{Q} 2 /(\mathrm{Q} 2+\mathrm{Q} 4))) \times(\mathrm{Q} 5 / 10)]
$$


Más tevékenységekben aktivitás csökkenés (\%): Mindennapi tevékenységek során tapasztalt egészségi állapot miatti produktivitás csökkenés: Q6/10

WPAI értékek százalékban kerülnek kifejezésre, ahol a magasabb értek nagyobb mértékü korlátozottságot és produktivitás veszteséget jelez (Reilly et al., 2004, Reilly-Associates, 2019).

\subsubsection{Az egészségügyi technológiaértékelés szerepe, egészségpolitika és finanszírozás}

Hazánkban számos jogszabály rendelkezik az egészségügyi ellátás során figyelembe veendő szempontokról: a hatásosság, a gazdaságosság és a költséghatékonyság szerepéről (1993. évi költségvetéséről szóló törvény, 1992. évi LXXXIV. törvény, 1997. évi LXXXIII. törvény) (Kobelt et al., 2017). Az egészségügyi technológiaértékelés (Health Technology Assessment - HTA) szabályozása hazánkban 2002-re nyúlik vissza, amikor Magyarországon az első egészségügyi technológiaértékelési szakmai irányelv kihirdetésre került, ez a irányelv 2013-ban került először frissítésre (Kobelt et al., 2017).

A hazai HTA guideline, az „Emberi Erőforrások Minisztériuma szakmai irányelve az egészségügyi technológia értékelés módszertanáról és ennek keretében költséghatékonysági elemzések készítéséről” (2017. EüK. 3. szám közlemény 10) kitér a legfontosabb fejezetekre: az adott technológia bemutatásának igénye, az összehasonlításra kerülő gyógyító-megelőző technológiák ismertetése, a perspektíva megválasztása, az egészség-gazdaságtani elemzés típusa, az alkalmazott eljárásokhoz kapcsolódó egészségnyereség mérése, a költségek számítása, az elemzés időhorizontja, diszkontálás, valamint az eredmények részletes bemutatása, költségvetésihatás-elemzés (Budget Impact Analysis) és egyéb szempontok (Kobelt et al., 2017). 
A legfontosabb cél a finanszírozási döntések előkészítése és az új terápiák társadalombiztosítási rendszerbe történő befogadása során az adott egészségügyi technológia (megelőzés, szürés, diagnosztika, terápia) költségeinek és hasznának felmérése. Magyarországon is jogszabály írja elő az egészségpolitikai és finanszírozási döntések meghozatalát megelőző költséghatékonysági és költségvetési-hatás vizsgálatok folytatásának szükségességet (7/2016. (III. 30.) EMMI rendelet) (EMMI, 2017).

Az Európai Egészségügyi Technológiaértékelési Hálózat (European Network for Health Technology Assessment - EUnetHTA) az egészségügyi technológiaértékelést ,az egészségügy technológiák használatával kapcsolatban rendelkezésre álló orvosi, szociális, gazdasági és etikai információkat összegezi transzparens, pártatlan és robosztus módon" (EUnetHTA, 2007, EUnetHTA, 2019) müködő folyamatként határozza meg. Amelynek ,a lehető legértékesebb, betegközpontú, biztonságos és hatékony egészségügyi intézkedések” támogatása a legfontosabb célja (EUnetHTA, 2007). A EUHTA által ajánlott HTA modulok a az alábbiak szerint határolhatóak el: relatív hatékonyságelemzés (a technológia jelenlegi alkalmazási módja, technikai jellemzők, biztonság, klinikai hatékonyság) és a lokális értékelés (költségek és gazdasági értékelés, etikai értékelés, szervezeti hatások, betegszintü és társadalmi hatások, jogi hatások) (EUnetHTA, 2007, EUnetHTA, 2019).

Az egészséggazdaságtani értékelés leggyakrabban az alábbi elemzéseket foglalja magában: költség-hasznosság elemzés és a költségvetési hatás elemzése. Ezekben az elemzések az adott új technológiát egy már általánosan elfogadott és alkalmazott technológiával hasonlítják össze. A költség-hasznosság elemzés (Cost-Utility Analysis, CUA) életminőséggel korrigált életévekben (Quality Adjusted Life Years, QALY) mért egészségkimeneteket állítja szembe a költségekkel. A költségvetési hatás elemzés (Budget Impact Analysis, BIA) pedig az adott új technológia bevezetésének a pénzügyi vonzataira fókuszál (Gulácsi et al., 2012). 


\subsubsection{Magyarországi egészségügyi online költség katalógus}

Európában négy országban van 'cost-library', ezek az Egyesült Királyság, Hollandia, Németország és Ausztria. Részlegesen, regionális, autonóm tartományi szinten állnak rendelkezésre ilyen adatok Spanyolországban, Olaszországban, és Svédországban is.

A régiónk országai közül Ausztria rendelkezik saját 'cost-library'-vel. A Department of Health Economics, Center for Public Health, Medical University of Vienna által készített és kezelt 'cost-library' célja a rendelkezésre álló egységköltségek, valamint a különféle egységköltség-forrásainak közlése.

A Magyarországi egészségügyi online költség katalógus létrehozása 2016-ban kezdődött, ekkor a Budapesti Corvinus Egyetem Egészségügyi Közgazdaságtan Tanszéke MNB pályázat során támogatást kapott egy ezzel foglalkozó nemzetközi konferencia megszervezéséhez, ezzel ténylegesen megkezdődött a Magyarországi egészségügyi online költség katalógus tervezésének folyamata.

A hazai Magyarországi egészségügyi online költség katalógus létrehozása során a bécsi példát tekintettük mérvadónak. Döntésünket az motiválta, hogy a bécsi 'cost-library' olyan pragmatikus módszertant követett, amely során egy saját tanszékünkhöz nagyon hasonló méretű egyetemi tanszék, saját emberi erőforrással, és kis összegű pályázati pénz felhasználásával, néhány év alatt is igen lényeges eredményt tudott elérni ezen a téren - azaz létre tudta hozni az osztrák egészségügyi 'cost-library'-t. Lényeges szempont volt az is, hogy a bécsi tanszékkel való közös munka során lehetőségünk nyílt folyamatos konzultációra, amely munkánkat igen nagymértékben segítette. 


\section{HIPOTÉZISEK}

\section{1. Életminőség mérés}

Dolgozatomban a következő hipotéziseket vizsgálom:

Az európai, lengyel, szlovén és UK EQ-5D-3L értékkészlet összehasonlitása 18 krónikus betegségben; hazai adatok alapján

\section{Hipotézis}

Feltételezzük, hogy az európai, lengyel, szlovén és UK EQ-5D-3L értékkészlet nem tér el egymástól lényegesen.

Alhipotézis:

1.1. Feltételezzük, hogy a különbözö értékkészleteket alkalmazzuk a vizsgált 18 krónikus betegségben akkor az eredmények alapján kialakított egészségpolitikai és finanszírozási döntések nem térnek el egymástól lényegesen a különböző országokban.

A DLQI kérdöiv „, nem releváns” válaszainak részletes elemzése

\section{Hipotézis}

Feltételezzük, hogy a DLQI kérdöív esetében a nem releváns válaszainak az elemzése különbségeket fog mutatni a különböző demográfiai és társadalmigazdasági jellemzőkel rendelkező csoportok között.

Alhipotézis:

2.1. Feltételezzük, hogy a különbségek orvosi döntéshozatalra, forrásallokációra gyakorolt hatása észlelhető. 
A magyarországi lakosság egészségi állapota és munkaképessége

\section{Hipotézis}

Feltételezzük, hogy a magyarországi lakosság egészségi állapota és munkaképessége az általunk alkalmazott mércékkel megfelelően jellemezhető.

Informális ellátás és meghatározó tényezői krónikus betegségekben: magyarországi kutatások összehasonlító elemzése

\section{Hipotézis}

Feltételezzük, hogy az informális ellátás jellemzői és meghatározó tényezői, hazánkban hasonlóak más országokéhoz.

\subsection{Költségszámítás}

Az informális ellátás költsége krónikus betegségekben: magyarországi kutatások összehasonlitó elemzés

\section{Hipotézis}

Feltételezzük, hogy az informális ellátás társadalmi terhe, költsége, hazánkban is a nemzetközi tapasztalatoknak megfelelően igen jelentős.

Betegségköltség vizsgálatok áttekintése kilenc Közép-Kelet-Európai országban

6.Hipotézis

Feltételezzük, hogy a betegség költségek hazánkban hasonlatosak más KözépKelet-Európai országokéhoz.

Alhipotézis:

6.1. Feltételezzük, hogy hazánkban a Közép-Kelet-Európai országban publikált költség adatok jobban felhasználhatóak és transzferálhatóak, mint a magas nemzeti jövedelemmel rendelkező országok költség adatai. 
Magyarországi egészségügyi online költség katalógus

\section{Hipotézis}

Feltételezzük, hogy a Magyarországi egészségügyi online költség katalógus létrehozásához rendelkezünk elegendő hazai adattal és a Magyarországi egészségügyi online költség katalógus létrehozható.

Alhipotézisek:

7.1. Feltételezzük, hogy a Magyarországi egészségügyi online költség katalógusa hozzájárulhat a megfelelö és fenntartható egészségügyi finanszírozási döntések kialakításához.

7.2. Feltételezzük, hogy a hazai egységköltségek és költségek jelentősen eltérnek a magas jövedelemmel rendelkező országokétól. 


\section{CÉLKITÜZÉSEK}

\section{1. Életminőség mérés}

\subsubsection{Az európai, lengyel, szlovén és UK EQ-5D-3L értékkészlet összehasonlítása 18 krónikus betegségben; hazai adatok alapján}

Kutatásunkban a szlovén, lengyel, európai és UK értékkészleteket kívántuk összehasonlítani, hiszen ezek kerülnek leggyakrabban használatra a Közép-KeletEurópai régióban. Kutatásunk 18 különböző betegségben folytatott keresztmetszeti, Magyarországon folytatott kutatás összehasonlító elemzését foglalta magában. A négy vizsgált értékkészlet összehasonlítását diagnózis, életkor-csoport és betegségsúlyosság szerint is elvégeztük, továbbá elemeztük az értékkészlet választás potenciális hatását az egészségügyi prioritások kialakítása során, azzal, hogy megvizsgáltuk a különböző betegségekben felmerülö betegségteher alakulását az eltérő értékkészletek alkalmazásával.

\subsubsection{A DLQI kérdőív „nem releváns” válaszainak részletes elemzése}

Kutatásunk célja a „nem releváns” (NRR) válaszok elfordulásának felderítése és elemzése egy nagy, pszoriázisban szenvedő betegekből álló minta segítségével. Arra kívánunk választ kapni, hogy a NRR előfordulása eltérő-e a különböző demográfiai és társadalmi-gazdasági jellemzőkkel bíró csoportok estén és ezeknek az eltéréseknek van-e hatása az orvosi döntéshozásra, és ezen keresztül a társadalombiztosítási források allokációjára.

Az NRR válaszok gyakori előfordulása A DLQI kérdőív validitásával kapcsolatos problémákat is felvethetnek, kutatásunk során erre a kérdésre is kitértünk. 


\subsubsection{A magyarországi lakosság egészségi állapota és munkaképessége}

Jelen kutatásunkban a lakosság egészségi állapot, jól-létét és munkaképességét kívántuk különböző mércékkel vizsgálni (például: ICECAP, WPAI és EQ-5D-5L kérdőívek) amelyek alkalmasak a kimenetelek értékelésére és számos szektor (egészségügyi-szociális szektor, munkaerőpiac) stratégia alkotásának értékeléséhez járulnak hozzá.

\subsubsection{Informális ellátás és meghatározó tényezői krónikus betegségekben: magyarországi kutatások összehasonlító elemzése}

Kutatásunk célja az informális ellátás jellemzőinek áttekintése és meghatározó tényezőinek elemzése magyarországi krónikus betegséggel élők körében, különös tekintettel az informális ellátás és a betegek EQ-5D kérdőívvel mért általános egészségi állapota közötti összefüggésekre. Elemzésünk során olyan korábbi vizsgálatokra támaszkodunk, ahol betegszintű adatok állnak rendelkezésünkre, így lehetőség volt a minták együttes elemzésére.

\subsection{Költségszámítás}

\subsubsection{Az informális ellátás költsége krónikus betegségekben: magyarországi kutatások összehasonlító elemzés}

Kutatásunk célja, az informális ellátás költségeinek áttekintése, elemzése és összehasonlítása különböző krónikus betegségekben Magyarországon. Elemzésünk korábbi vizsgálatokra épít, amelyekben betegszintű adatok állnak rendelkezésünkre. 


\subsubsection{Betegségköltség vizsgálatok áttekintése kilenc Közép-Kelet-Európai országban}

A jelen kutatásunkban szereplő irodalom áttekintés a betegségköltség kutatások vizsgálatára irányul kilenc Közép-Kelet-Európai országban (Ausztria, Bulgária, Csehország, Horvátország, Lengyelország, Magyarország, Románia, Szlovénia és Szlovákia) az elmúlt tíz évre vonatkozóan. Kutatásunk legfőbb célja a publikációk jellemzőinek elemzése, a használt módszertanok megismerése és az ezekben publikált betegségköltségek validitásának és összehasonlíthatóságának vizsgálata volt. Kutatásunkban a publikációkban megjelenő módszertanról adunk összefoglalást, továbbá a betegségköltségek vizsgálatára és a Közép-KeletEurópai régión belüli összehasonlítására törekszünk.

\subsubsection{Magyarországi egészségügyi online költség katalógus}

Célunk egy országspecifikus adatokat tartalmazó, Magyarországi egészségügyi online költség katalógus kialakítása. Vizsgáljuk ezen adatbázis egészségpolitikaifinanszírozási felhasználási lehetőségeit hazánkban. Szeretnénk választ kapni arra a kérdésre is, hogy hazánkban a döntésekhez szükséges költség és más egészségügyi gazdaságtani eredményeket mely országokból célszerü a leginkább átvenni. 


\section{MÓDSZEREK}

\section{1. Életminőség mérés}

\subsubsection{Az európai, lengyel, szlovén és UK EQ-5D-3L értékkészlet összehasonlítása 18 krónikus betegségben}

5.1.1.1. A vizsgált EQ-5D-3L értékkészletek

EQ-5D-3L értékkészlet számos országban kidolgozásra került. A Közép-KeletEurópai régióban azonban csak Lengyelország és Szlovénia rendelkezik saját országspecifikus értékkészlettel. A régió országaiban az értékeléshez gyakran az Egyesült Királyság (továbbiakban UK) hasznosság értékkészlete került felhasználásra (Devlin et al., 2017), például Magyarországon lakossági felmérésekben is ezt alkalmazták (Baji et al., 2015, EuroQolGroup, Dolan, 1997, Rencz et al., 2016). Az európai értékkészlet kialakítás 6 ország bevonásával, több országban való használatra készült, azonban a régió országaiban jelenleg nem széles körben elterjedt az alkalmazása (Greiner et al., 2003, Rencz et al., 2016). Jelen kutatásunkban négy értékkészletet hasonlítottunk össze: Lengyelország, Szlovénia, EU és az Egyesült Királyság (UK) értékkészletét.

\subsubsection{Minta}

A Budapesti Corvinus Egyetem Egészségügyi Közgazdaságtan Tanszékének korábbi kutatási adatait dolgoztuk fel másodlagosan. Azokat a kutatási eredményeket, adatbázisokat kívántuk elemzésünkbe bevonni, amelyek krónikus betegségekben az EQ-5D-3L validált kérdőívet használták a betegek egészségi állapotának felmérésére. Csak azok a betegek kerültek bevonásra, akik mind az öt dimenzióban rendelkeztek válasszal, és így az EQ-5D-3L index értékük kiszámítható volt. Kutatásunkban 18 korábbi kutatás elemzésére került sor. 


\subsubsection{Statisztikai elemzés}

Betegségeként eltérő elemszámú mintával rendelkeztünk, ezért egy egyenletes minta kialakításához súlyokat alkalmaztunk Kiszámítottuk a súlyozott átlag és százalékos megoszlás értékeket a teljes mintánkra. A négy értékkészletet a (1) az EQ-5D-3L dimenziók, (2) a diagnózis, (3) a beteg szubjektív egészségi állapot értékelése (EQ VAS) és az (4) életkor szerinti csoportok összehasonlítását végeztük el. Az egyes dimenziókban jelentett problémák összehasonlítását vizuális ábrázolással mutattuk be: a mérsékel és súlyos problémát jelentők arányának megjelenítésével.

Az index értékek eloszlása ugyan nem volt normális eloszlásúnak tekinthető, azonban a mintanagyság lehetővé tette a páros t próbák elvégzését az eltérő diagnózisok közötti eltérések elemzésére. A különböző életkor szerinti csoportok összehasonlítására OLS regressziós modellt építettünk. Végezetül minden értékkészlet esetében kiszámoltunk egy úgynevezett betegségteher (disease burden - DB) értéket és ennek értékkészlet választásra való szenzitivitását.

\subsubsection{A DLQI kérdőív „nem releváns” válaszainak részletes elemzése}

\subsubsection{Kérdőíves vizsgálat}

Két keresztmetszeti kérdöíves vizsgálatot végeztünk Magyarországon, két klinikán, pszoriázisban szenvedő betegek körében. Az első vizsgálat 2012 és 2013 között folyt, 200 beteg bevonásával, a második kérdőíves felmérés pedig 2015 és 2016 között 238 eltérő betegségsúlyosságú pszoriázis beteg bevonásával történt. Mindkét kérdőíves felmérésben szereplö betegek válaszait csak egy alkalommal vettük figyelembe, valamint kizárásra kerültek, azon betegek, akik DLQI pontszáma hiányzó adatok miatt nem volt kalkulálható, így összesen 428 beteg került bele a mintánkba. 


\subsubsection{2. Életminőség mércék}

A betegek általános egészségi állapotának értékelésére az EQ-5D-3L kérdőívet használtuk. A betegségspecifikus életminőség mérésére a DLQI kérdőívet használtuk. A betegségsúlyosság felmérésére a kezelőorvosok által kitöltött un. „psoriasis kiterjedési és súlyossági index” (Psoriasis Area Severity Index - PASI) score került használatra, amely értéke 0 és 72 között mozoghat, ahol a magasabb értékek a nagyobb betegségsúlyosságra utalnak.

\subsubsection{Statisztikai elemzés}

A teljes mintánkra vonatkozóan deskriptív statisztikákat végeztünk. A DLQI pontszámok alapján alcsoportokat képeztünk. A „,nem releváns” DLQI válaszok értékelésére két módszert használtunk: a „nem releváns” DLQI válaszok gyakoriságát meghatároztuk, valamint az egy beteg esetében felmerülő „nem releváns” DLQI válaszok számát megállapítottuk (amely 0 és 8 közötti értéket vehetett fel).

Az adataink nem normális eloszlása miatt nem parametrikus teszteket használtunk. A nem releváns válaszok meghatározó tényezőinek felderítésére többváltozós logisztikus regressziós modellt építettünk. A nem és a nem releváns válaszok között kapcsolatot khí négyzet próbáltval vizsgáltuk. Az elemzéseket IBM SPSS Statistics for Windows, Version 22.0. Armonk, NY: IBM Corp. (2013) programban végeztük. 


\subsubsection{A magyarországi lakosság egészségi állapota és munkaképessége}

\subsubsection{Kérdőíves vizsgálat}

Keresztmetszeti kérdőíves vizsgálatot végeztünk 2019 május - júniusban egy a magyar lakosság legfontosabb demográfiai jellemzői szerint reprezentatív mintán. A kérdőíves vizsgálathoz az etikai engedélyt a Tudományos és Kutatásetikai Bizottság adta (engedélyszám: 10058-3/2019/EKU). A résztvevők a vizsgálatban való részvételhez beleegyezésüket adták.

A kérdőíves vizsgálat egy nagyobb, populációt felmérő vizsgálat részét képezte (Baji et al., 2019). A magyarországi lakosság egészségi állapota és munkaképességének felmérése érdekében a következő szekciókra helyeztünk hangsúlyt:

- Szocio-demográfiai jellemzők: életkor, nem, iskolai végzettség, családi állapot

- Foglalkoztatási helyzet

- A válaszadó háztartásának jellemzői (háztartás-méret, nettó havi bevétel, lakóhely típusa és helye)

- A válaszadó egészségi állapota

- A válaszadó munkaképessége

\subsubsection{Használt mércék}

A munkatermelékenység veszteség mérésére a dolgozatban korábban bemutatott WPAI-GH kérdőívet, a résztvevők egészségi állapotának felmérésére az EQ-5D kérdőívet, a MEHM (Minimum European Health Module)-t és az ICECAP-A (65 év alatti válaszadók) valamint az ICECAP-O (65 évnél idősebb válaszadók) kérdőíveket használtuk. Az ICECAP kérdőív értékeléséhez az Egyesült Királyság tarifát használtuk 


\subsubsection{Statisztikai elemzés}

A kérdőívekből származó adatokból adatbázist építettünk IBM SPSS Statistics 25 (IBM SPSS, Version 25.0. Armonk, NY:IBM Corp., 2012)) programban. A résztvevők munkatermelékenységének, egészségi állapotának és jól-létének jellemzésére leíró statisztikákat végeztünk. A WPAI kérdőívvel mért munkatermelékenység veszteség mérésére alcsoport elemzést végeztünk. Az

eltérések szignifikanciájának tesztelésére nem parametrikus teszteket alkalmaztunk (Kruskal-Wallis és Mann-Whitney U tesztek). Az eltérő mércék közötti összefüggések felderítésére páronkénti Spearman-féle rangkorrelációkat számoltunk, a változóink nem normális eloszlása miatt.

\subsubsection{Informális ellátás és meghatározó tényezői krónikus betegségekben: magyarországi kutatások összehasonlító elemzése}

\subsubsection{Beválogatott vizsgálatok}

A Budapesti Corvinus Egyetem Egészségügyi Közgazdasági Tanszéke által az elmúlt években végzett kérdöíves kutatásait tekintettük át. Azok a vizsgálatok kerültek beválogatásra, ahol keresztmetszeti felmérés keretében mérték fel az informális ellátást krónikus betegségekben hazai betegek körében, az EQ-5D kérdőív un. 3L változata (lásd lentebb) is kitöltésre került és (anonimizált) betegszintü adatok álltak rendelkezésre.

\subsubsection{Informális ellátást célzó kérdések a vizsgálatokban}

Az igénybe vett informális ellátás felmérésére a Tanszék által összeállított kérdéssort alkalmaztak a vizsgálatokban, kivéve demencia esetében, ezért azt külön tárgyaljuk. Az informális ellátást egységesen az elmúlt hétre vonatkozóan mérték fel és mindegyik esetben maguk a betegek válaszolták meg a kérdéseket. 
A vizsgálatok többségében a betegeknek az elmúlt héten igénybe vett óraszámot kellett megadniuk, kivéve az epilepszia, a jóindulatú prosztata megnagyobbodás (benign prostatic hyperplasia, BPH) és az oszteroporózis vizsgálatokat, ahol a heti alkalmak számát és az alkalmankénti óraszámot kérdezték meg, ezért ezek szorzatát használtuk. A húgyhólyagrák (bladder cancer, BC) esetében az informális ellátás heti alkalmának és az alkalmankénti óraszámára vonatkozó kérdésekre adott válaszok rendkívül hiányosak voltak, ezért ezt a változót nem vettük be az informális ellátás óraszámmal kapcsolatos elemzésekbe.

A demencia felmérés egy nemzetközi vizsgálat keretében zajlott és a formális, illetve az informális erőforrások felhasználásának mérésére egy speciális, kifejezetten a demencia felmérésére kifejlesztett standard kérdőívet alkalmaztak, mely magába foglalta az informális ellátásra vonatkozó kérdéseket is (Érsek et al., 2010). A Resource Utilization in Dementia (RUD) egy standard kérdöív, amely alkalmas a demencia okán felmerülő erőforrás-felhasználás és költségek összehasonlítására az eltérő országokban. A kérdőív széles körben használt, a kutatásban a RUD magyar változatát alkalmazták (EuroQolGroup, 1990). Elemzésünkben a RUD kérdőívből származó, egy hónapra vonatkozó informális ellátás időtartamokat arányosítottuk egy heti óraszámra.

A más személytől kapott segítség idejét alapesetben betegenként 24 óra/nap (azaz heti 168 óra) idöre maximáltuk. Ezzel ugyan kizártuk azokat az eseteket, ahol a beteg bevallása szerint 24 óránál többet foglalkoznak vele, ami a valóságban lehetséges, ha több gondozó segíti és felügyeli a beteget, de el akartuk kerülni az informális ellátás túlbecslését. Másodlagos elemzést végeztünk egy konzervatívabb megközelítést alkalmazva, amikor napi 8 (azaz heti 56 órában) maximáltuk az informális ellátás óraszámát betegenként.

\subsubsection{Egészségi állapot felmérése EQ-5D kérdőívvel a vizsgálatokban}

A beválogatásra került vizsgálatokban az EQ-5D-3L validált magyar nyelvü verzióját alkalmazták, az értékeléshez az Egyesült Királyság hasznosság értékkészlete került felhasználásra (Devlin et al., 2017). 


\subsubsection{Adatbázis összeállítása}

A betegszintü adatok az eredeti adatbázisokból kerültek kigyüjtésre standard módon és IBM SPSS Statistics (IBM SPSS, Version 21.0. Armonk, NY: IBM Corp., 2012) programban kerültek rögzítésre. Rögzítettük a betegség típusát, a betegek életkorát, a betegek nemét, iskolai végezettségét, lakhatási helyzetét, a diagnózis felállítása óta eltelt időt, az EQ-5D-3L öt dimenziója és az EQ VAS által mért egészségi állapotát, valamint a betegek által igénybe vett informális ellátás heti óraszámát.

\subsubsection{Statisztikai elemzés}

A betegek demográfiai, egészséggel összefüggő életminőség, valamint informális ellátás igénybevételére vonatozó adataira deskriptív statisztikákat számoltunk. Az elemzéseket a teljes mintára, valamint a diagnózisok és az informális ellátás igénybevétel szerinti alcsoportokon végeztük el. Az adatok nem normális eloszlása miatt nem-parametrikus statisztikai próbákat használtunk. Az EQ-5D, EQ VAS és az igénybe vett informális ellátás idejének értéke között Spearmanféle korrelációt számoltunk. Az igénybe vett informális ellátás idejét magyarázó tényezőket lineáris regressziós modellel kívántuk felderíteni.

\subsection{Költségszámítás}

\subsubsection{Az informális ellátás költsége krónikus betegségekben:} magyarországi kutatások összehasonlító elemzése

\subsubsection{Minta}

A részletes módszertant más publikációnkban közöltük (Beretzky et al., 2017). A Budapesti Corvinus Egyetem Egészségügyi Közgazdasági Tanszékén az elmúlt 
években végzett kérdőíves kutatások közül azokat tekintettük át, amelyek az informális ellátás felmérésére is kiterjedtek és használták az egészségi állapot mérésére alkalmas, korábban bemutatott EQ-5D-3L kérdőívet. A kutatások során a tanszék által összeállított és a betegek által kitöltött kérdéssorok kerültek alkalmazásra, amelyek segítségével az informális ellátást a kitöltést megelőző hétre vonatkozóan mérték fel. Összesen 13 kutatás eredményének a másodlagos elemzését végeztük el, a következő betegség területeken: artritisz pszoriatika (AP, pikkelysömörös ízületi gyulladás) (Brodszky et al., 2009), időskori makuladegeneráció (age-related macular degeneration - AMD) (Brodszky et al., 2014a), demencia (Érsek et al., 2010), endometriózis (Simoens et al., 2012), epilepszia (Pentek et al., 2013), jóindulatú prosztata megnagyobbodás (benign prostatic hyperplasia - BPH) (Rencz et al., 2015c), oszteoporózis (csontritkulás) (Péntek et al., 2016b), Parkinson kór (Tamás et al., 2014), pszoriázis (pikkelysömör) (Balogh et al., 2014, Rencz et al., 2014), reumatoid artritisz (RA, sokízületi gyulladás) (Péntek et al., 2007), szisztémás szklerózis (SSc) (Minier et al., 2010), szklerózis multiplex (SM) (Péntek et al., 2012b), skizofrénia (Péntek et al., 2012c).

\subsubsection{2. Életminőség mérése}

Az egészséggel összefüggő életminőség felmérésére az EQ-5D-3L validált magyar változatát használtuk. Elemzésünkben külön figyelmet szerettünk volna fordítani a legrosszabb egészségi állapotban élők helyzetének a vizsgálatára. Ehhez az EQ-5D-3L segítségével számolt hasznosságokat (EQ-5D-3L index) vettük figyelembe, mégpedig úgy, hogy a legfeljebb 0 -val egyenlö hasznossággal rendelkezőket tekintettük a legrosszabb egészségi állapotban élőknek.

\subsubsection{Informális ellátás}

Az informális ellátás túlbecslésének elkerülése érdekében a más személytől kapott segítség idejét alapesetben betegenként 24 óra/nap (azaz heti 168 óra) időre maximáltuk. Másodlagos elemzésünkben egy konzervatívabb megközelítést alkalmaztunk és napi 8 (azaz heti 56 órában) maximáltuk az informális ellátás 
óraszámát betegenként. Az informális ellátás költségének meghatározásához a heti szinten igénybe vett informális ellátás óraszámát használtuk alapul. Az óraszámokat az átlagos nettó órabérrel szoroztuk fel, amely 973 forint volt 2017ben (KSH, 2017).

\subsubsection{Betegségköltség vizsgálatok áttekintése kilenc Közép-Kelet-Európai országban}

\subsubsection{Keresési stratégia}

A PRISMA kritériumok figyelembevételével szisztematikus irodalomkeresést folytattunk. Irodalomkeresésünk a Medline, EMBASE, The Cochrane Library, CINAHL és Web of Science adatbázisunkra terjedt ki, annak érdekében, hogy azonosítsuk a betegségköltségre vonatkozó adatokat tartalmazó publikációkat. A keresési stratégia a „cost of illness” kifejezés és az adott ország nevének kombinációjából ált. A keresésünk a 2006. január 1. és 2017. június 30. között megjelent publikációkat tekintette át, a publikációk nyelvére vonatkozóan nem alkalmaztunk feltételeket. A nem-indexált irodalmak azonosítása érdekében kiegészítő, kézi keresést folytattunk Ausztria, Magyarország és Románia esetében.

\subsubsection{A publikációk kiválasztása}

A keresést követően a találatokat cím és absztrakt alapján vizsgáltuk meg, majd második körben a teljes szövegüket megvizsgálva döntöttünk beválogatásukról. A kizárólag absztraktként megjelent és a review közlemények kizárásra kerültekA duplikátumok kizárása után a publikációk címük és absztraktjuk alapján kerültek vizsgálatra. A kizárólag absztraktként megjelent és a review publikációk kizárásra kerültek.

Beválogatásra azok a publikációk kerültek, amelyek: 1. valamilyen specifikus betegségre vonatkozóan tartalmaztak cost of illness adatokat, 2. a publikáció eredeti közlemény volt, 3 . teljes terjedelemben elérhető, 4. a publikációban 
szereplő betegpopuláció Ausztria, Bulgária, Csehország, Horvátország, Magyarország, Szlovénia, Szlovákia, Románia vagy Lengyelországból került beválogatásra.

\subsubsection{Az adatbázis összeállítása}

Miscrosoft Excel egy összesítő táblázatban foglaltuk össze a beválogatásra került közlemények legfontosabb adatait (publikáció éve, helye, nyelve és anyagi támogatására vonatkozó státusza). A publikációban alkalmazott perspektíva, a publikációban szereplő diagnózis/intervenció megnevezése) és az ezekben szereplő költség adatok azonosításra kerültek.

\subsubsection{A Magyarországi egészségügyi online költség katalógus}

Az irodalomkeresést négy lepésben folytattuk, a betegségköltség (cost of illness) publikációk, cost-effectiveness, budget-impact analysis publikációk keresésével, a hazai, magyar nyelvü irodalom esetében kézi keresést végeztünk. A keresés frissítésekor szabadszavas keresést végeztünk „cost” keresőkifejezésre.

A keresések az alábbiak szerint alakultak:

1. betegségköltség (cost of illness) publikációk keresése, időtáv: 2006. január 1. - 2017. június 30 .

2. cost-effectiveness, budget-impact analysis publikációk keresése, időtáv: 2006. január 1. - 2017. június 30.

3. magyarországi, magyar nyelvű irodalomban történő kézi keresése, időtáv: 2006. január 1.- 2020. március 21.

4. a keresés frissítése a legújabb publikációk azonosítása érdekében. időtáv: 2017. július 1. - 2020. március 21. 
5.2.3.1.Betegségköltség (cost of illness) publikációk keresése

Irodalomkeresést folytattunk a Medline, EMBASE, The Cochrane Library, CINAHL, és Web of Science adatbázisokban, a valamely betegség költségét tartalmazó publikációk azonosítása céljából. A keresési stratégia a “cost of illness" keresőkifejezés és a "Hungary” kifejezés kombinációjából ${ }^{7}$ állt.

A keresésünk a 2006. január 1. és 2017. június 30. között megjelent, angol és magyar nyelvü publikációkat tekintette át.

A keresést követően a találatokat cím és absztrakt alapján vizsgáltuk meg, majd második körben a teljes szövegüket megvizsgálva döntöttünk beválogatásukról. A kizárólag absztraktként megjelent és a review közlemények kizárásra kerültek.

Beválogatásra azok a publikációk kerültek, amelyek:

1. valamilyen specifikus betegségre vonatkozóan tartalmaztak cost of illness adatokat,

2. eredeti közlemények voltak, teljes terjedelemben elérhetőek voltak,

3. a publikációban szereplő betegpopuláció Magyarországon került beválogatásra.

5.2.3.2. Cost-effectiveness, budget-impact analysis publikációk keresése

A cost-effectiveness, budget-impact analysis elemzések azonosítása érdekében az OVID MEDLINE adatbázisban végeztünk keresést ${ }^{8}$. A keresésünk a 2006. január

\footnotetext{
${ }^{7}$ cost of illness"[MeSH Terms] AND "hungary" AND ("2006/01/01"[PDAT]:"2017/06/01"[PDAT])

8 "Economics"[Mesh:NoExp] or "Costs and Cost Analysis"[Mesh] or "Costs and Cost Analysis"[Mesh] or "Economics, Hospital"[Mesh] or "Economics, Dental"[Mesh:NoExp] or "Economics, Medical"[Mesh:NoExp] or "Economics, Nursing"[Mesh] or "Economics, Pharmaceutical"[Mesh] or (economic*[Title/Abstract] or cost[Title/ Abstract] or costs[Title/Abstract] or costly [Title/Abstract] or costing[Title/ Abstract] or price[Title/Abstract] or prices[Title/Abstract] or pricing[Title/ Abstract] or pharmacoeconomic*[Title/Abstract] or expenditure*[Title/Abstract] not energy[Title/Abstract] or value for money [Title/Abstract] or budget*[Title/Abstract]) not (energy cost[Title/Abstract] oxygen cost[Title/Abstract] or metabolic cost[Title/Abstract] or energy expenditure[Title/Abstract] OR oxygen expenditure[Title/Abstract]) not (letter[Publication Type] or editorial[Publication Type] or historical article [Publication Type]) not animals[mesh:noexp] not (animals[mesh:noexp] and humans[mesh])) AND hungary AND ("2006/01/01"[PDAT] : "2016/09/16"[PDAT]
} 
1. és 2017. június 30. között megjelent, angol és magyar nyelvü publikációkat tekintette át.

A keresést követően a találatokat cím és absztrakt alapján vizsgáltuk meg, majd második körben a teljes szövegüket megvizsgálva döntöttünk beválogatásukról.

A kizárólag absztraktként megjelent és a review közlemények kizárásra kerültek. A találatok közül beválogatásra azok a publikációk kerültek, amelyek:

1. cost-effectivness, budget impat analysis vagy cost of illness elemzést tartalmaztak, illetve bármilyen unit cost adatot közöltek

2. eredeti közlemények voltak, teljes terjedelemben elérhetőek voltak,

3. a publikációban szereplő betegpopuláció Magyarországon került beválogatásra.

\subsubsection{Magyarországi, magyar nyelvű irodalomban történő kézi keresés}

A nem-indexált, helyi irodalmak azonosítása érdekében kézi keresést folytattunk a magyar nyelvű folyóiratok tartalomjegyzékeinek kereshető adatbázisán (MATARKA, https://matarka.hu/), amely adatbázis a Magyarországon megjelenő tudományos és szakmai folyóiratok tartalomjegyzékeit kereshető formában listázza. A releváns találatok áttekintése után, a valamilyen betegségköltségre, költséghatékonyságra vonatkozó adatokat tartalmazó eredeti közlemények kerültek beválogatásra.

Irodalomáttekintésünk magában foglalta a releváns technológiaelemzési jelentések áttekintését is. Olyan a Budapesti Corvinus Egyetem Egészségügyi Közgazdaságtan Tanszék (és jogelődjei) által készített technológiaelemzési jelentések kerültek beválogatásra, amelyek ISBN számmal rendelkeznek, publikusan elérhetőek és egy adott betegség/terápiára vonatkozóan hazai költség adatokat közöltek. Az Országos Egészségbiztosítási Pénztár és jogutódainak (Nemzeti Egészségbiztosítási Alapkezelö) weboldalán egyetlen valamilyen specifikus diagnózist vagy intervenciót tárgyaló technológiaelemzési jelentés sem érhető el (http://www.neak.gov.hu/felso_menu/szakmai_oldalak). A korábban müködő Egészségügyi Stratégiai Kutatóintézet (ESKI) archívuma jelenleg már 
nem elérhető az Nemzeti Erőforrás Minisztérium weboldalán (https://www.kormany.hu/hu/emberi-eroforrasokminiszteriuma/egeszsegugyertfelelos-allamtitkarsag). A jelenleg müködő Állami Egészségügyi Ellátó Központ (ÁEEK; 2015. március 1. előtti elnevezése: Gyógyszerészeti és Egészségügyi Minőség- és Szervezetfejlesztési Intézet) jelenleg szabadon elérhető kiadványai (ERA- Egészségügyi Rendszerek Adattára) között nem szerepelt egy specifikus diagnózisra vagy intervenció költséghatékonyságára vonatkozó technológiaelemzési jelentés (AEEK, 2019b, AEEK, 2019a).

\subsubsection{A keresés frissítése}

A 2017. július 1. és 2020. március 21. között megjelent publikációk azonosítása érdekében szabadszavas keresést folytattunk, „cost” keresőkifejezéssel a Pubmed Medline adatbázison. A keresésben megjelölésre került a „Hungary” kifejezés is és a keresni kívánt keresési időtartam megjelölése ${ }^{9}$ A találatokat átvizsgáltuk és az alábbiak szerint végeztük el a beválogatást: Ez esetben is kizárásra kerültek a csak absztrakt formájában megjelent, valamint a review cikkek. Ezt követően a találatokat cím és absztrakt alapján vizsgáltuk meg, majd második körben a teljes szövegüket megvizsgálva döntöttünk beválogatásukról, az alábbi kritériumok szerint:

1. tartalmaztak valamilyen betegségre vagy intervencióra vonatkozó költségadatot, vagy nem betegségspecifikus egészségügyi költséget

2. eredeti közlemények és teljes terjedelemben elérhetőek voltak,

3. a publikációban szereplő betegpopuláció Magyarországon került beválogatásra.

A keresés frissítésekor, annak érdekében, hogy ne veszítsük találatokat a „cost” szabadszavas keresési stratégiát folytattuk, amely eredményeképpen számos nem releváns, vagy nem az egészséggazdaságtan területéhet szorosan kapcsolódó publikáció jelent meg találataink között, ezek kizárásra kerültek.

\footnotetext{
9 cost[All Fields] AND ("hungary"[MeSH Terms] OR "hungary"[All Fields]) AND ("2017/07/01"[PDAT] : "2020/03/21"[PDAT])
} 
5.2.3.5. A Magyarországi egészségügyi online költség katalógus összeállítása

A beválogatásra került közlemények legfontosabb adatait (publikáció éve, költségszámítás éve, a publikációban alkalmazott perspektíva, a publikációban szereplő diagnózis/intervenció megnevezése) és az ezekben szereplő költség adatokat Miscrosoft Excel egy összesítő táblázatban foglaltuk össze.

A költségeket tankönyvi felosztás szerint különítettük el (Gulácsi et al., 2012): direkt-egészségügyi költségek, direkt nem-egészségügyi költségek és indirekt költségek. A fö költség kategóriákon belül a költségeket aszerint osztályoztuk, hogy a járóbeteg vagy fekvőbeteg ellátás során felmerülő költségeket különíthettünk el.

A Magyarországi egészségügyi online költség katalógus a társadalombiztosítás által nem finanszírozott termékek és szolgáltatások költségeit is tartalmazza, ezeket külön jelöléssel kezeltük. A publikációkban szereplő költségek esetében minden esetben azonosítani kívántuk, hogy az adott költség kiszámításához a szerzők milyen forrásokat alkalmaztak. Amennyiben az adott publikációban közlésre került, a költségek kiszámításához alkalmazott egység-költségeket is figyelembe vettük és megjelenítettük. A publikációkban azonosított költség adatokat aszerint is osztályoztuk, hogy milyen formában és milyen időtávra vonatkozóan kerültek közlésre a költségek. 


\title{
6. EREDMÉNYEK
}

\section{1. Életminőség mérés}

\subsubsection{Az európai, lengyel, szlovén és UK EQ-5D-3L értékkészlet összehasonlítása 18 krónikus betegségben}

\author{
6.1.1.1. A minta jellemzői
}

A 18 krónikus betegség 9 különböző ICD-10 csoportba tartozott. A teljes mintánk 2421 beteget foglalt magában: artritisz pszoriatika (PsA) (Brodszky et al., 2009), időskori makuladegeneráció (age-related macular degeneration - AMD) (Brodszky et al., 2010d), figyelemhiányos hiperaktivitás-zavar (attention deficit hyperactivity disorder - ADHD) (Pulay et al., 2016), demencia (Érsek et al., 2010), diabétesz (DM) (Brodszky et al., 2010d), endometriózis (ENDO) (Simoens et al., 2012), epilepszia (Pentek et al., 2013), húgyhólyagrák (BC) (Hever et al., 2015), jóindulatú prosztata megnagyobbodás (benign prostatic hyperplasia - BPH) (Rencz et al., 2015a), osteoporózis (OP) (Rencz et al., 2016), perifériás artériás érbetegségben (peripheral arterial occlusive disease - PAOD) (Balogh et al., 2013), Parkinson kór (PD) (Tamás et al., 2014), pszoriázis (PSO) (Rencz et al., 2014, Balogh et al., 2014), reumatoid artritisz (RA) (Péntek et al., 2007), hiperaktív hólyagszindróma (overactive bladder - OAB) (Péntek et al., 2012a), szisztémás szklerózis (systemic sclerosis - SSc) (Minier et al., 2010), szklerózis multiplex (multiple sclerosis - MS) (Péntek et al., 2012b) és skizofrénia (SCZ) (Péntek et al., 2012c) diagnózisokkal. (1. Táblázat)

A betegek átlagéletkora 55,87 ( $\mathrm{SD}=17,75)$ év volt. A betegek több mint fele 70 évnél idősebb volt demencia, időskori makuladegeneráció, jóindulatú prosztata megnagyobbodás és perifériás artériás érbetegség betegségekben. A betegek több mint fele nő volt $(\mathrm{n}=1356,58,6 \%)$ és fontos megemlíteni, hogy egyes betegségekben csak nőbetegek szerepeltek a mintánkban (endometriózis, oszteoporózis, hiperaktív hólyagszindróma) még jóindulatú prosztata megnagyobbodásban csak férfiak. Az átlagos betegségfennállási idő a 
mintánkban $8,75 \quad(\mathrm{SD}=8,95)$ év volt, kifejezetten magas átlagos betegségfennállási idővel a pszoriázis és az epilepszia esetében. (1. Táblázat) 


\section{Táblázat A mintában szereplő betegek demográfiai jellemzői}

\begin{tabular}{|c|c|c|c|c|}
\hline Betegségek & Betegszám (n) & Betegség fennállási idő (év) & Életkor átlag (SD) & Nö n (\%) \\
\hline Arthritisz pszoriatika & 177 & $9,30(9,24)$ & $49,89(12,76)$ & $101(57,1 \%)$ \\
\hline Pszoriázis & 192 & $21,66(11,77)$ & $50,49(12,79)$ & $61(31,8 \%)$ \\
\hline Perifériás artériás érbetegség & 103 & $\mathrm{NA}$ & $70,00(10,21)$ & $45(43,7 \%)$ \\
\hline Időskori makuladegeneráció & 122 & $2,94(2,54)$ & $75,16(7,88)$ & $76(62,3 \%)$ \\
\hline Reumatoid artritisz & 249 & $9,15(9,33)$ & $55,38(12,32)$ & $214(86,3 \%)$ \\
\hline Szisztémás szklerózis & 80 & $7,16(6,63)$ & $57,39(9,60)$ & $72(90,0 \%)$ \\
\hline Demencia & 86 & NA & $77,61(8,60)$ & $51(60,0 \%)$ \\
\hline Diabetétesz & 264 & NA & $61,31(10,98)$ & $151(57,2 \%)$ \\
\hline Endometriózis & 79 & $7,68(6,33)$ & $32,67(4,80)$ & $79(100 \%)$ \\
\hline Oszteoporózis & 207 & $7,49(5,60)$ & $69,57(8,93)$ & $207(100 \%)$ \\
\hline Figyelemhiányos hiperaktivitás-zavar & 75 & NA & $30,44(10,49)$ & $17(22,7 \%)$ \\
\hline Húgyhólyagrák & 148 & $3,56(3,78)$ & $66,24(9,61)$ & $50(33,8 \%)$ \\
\hline Jóindulatú prosztata megnagyobbodás & 237 & $5,53(4,79)$ & $70,38(8,18)$ & $0(0,0 \%)$ \\
\hline Epilepszia & 96 & $15,38(11,55)$ & $36,16(12,12)$ & $56(58,3 \%)$ \\
\hline Hiperaktív hólyagszindróma & 61 & NA & $57,72(11,56)$ & $61(100,0 \%)$ \\
\hline Parkinson kór & 99 & $8,08(5,59)$ & $62,67(11,32)$ & $31(33,0 \%)$ \\
\hline Skizofrénia & 78 & NA & $44,24(13,05)$ & $36(46,2 \%)$ \\
\hline Szklerózis multiplex & 68 & $7,02(5,90)$ & $37,96(9,08)$ & $48(70,6 \%)$ \\
\hline Összesen & 2421 & $8,99(9,28)$ & $58,33(16,41)$ & $1295,0 \%)$ \\
\hline
\end{tabular}

NA: nincs adat 


\subsubsection{Az EQ-5D-3L dimenziókban jelentett problémák}

A mintánkban 519 beteg (20,7\%) nem jelentett problémát egyik EQ-5D-3L dimenzióban sem, még 420 beteg $(16,1 \%)$ jelentett (bármilyen szintü) problémát mind az öt dimenzióban. Legalább egy dimenzióban súlyos problémát 419 beteg (17,6\%) jelentett, még 2002 beteg $(82,4 \%)$ egyik dimenzióban sem jelentett súlyos problémát.

A betegek a jelentett probléma szerinti megoszlását az 2. ábrán mutatjuk be. Problémát leggyakrabban a demenciában (96,5\%) reumatoid artritiszben (95.2\%), perifériás artériás érbetegségben $(95,2 \%)$ és arthritisz pszoriatikában $(94,4 \%)$ szenvedö betegek jelentettek, még legritkábban az endometriosiózisban (44,3\%), epilepsziában $(52,1 \%)$ és jóindulatú prosztata megnagyobbodásban szenvedők $(53,2 \%)$.

A teljes mintánkat figyelembe véve, a legkisebb mértékben érintett dimenzió az Önellátás volt, amelyben mérsékelt és súlyos problémát a betegek 20,5\% és 2,6\%-

a jelentett. A legtöbb problémát Fájdalom/rossz közérzet és Szorongás/lehangoltság dimenzióban jelentették a betegek: mérsékelt problémát $51,7 \%$ és $46,5 \%$, súlyos problémát: $10,3 \%$ és $9,0 \%$.

A bármilyen szintü problémát jelentők aránya Mozgékonyság, Önellátás, Szokásos tevékenységek, Fájdalom/rossz közérzet és Szorongás/lehangoltság dimenziókban a legmagasabb perifériás artériás érbetegségben (89,3\%), reumatoid artritisz $(56,2 \%)$, reumatoid artritisz (20,9\%), reumatoid artritisz ( $8.4 \%)$ és skizofrénia $(76,9 \%)$ diagnózisokban volt. (2. Ábra)

A demenciában szenvedő betegek jelentettek a legtöbb esetben súlyos problémát Mozgékonyság (11,3\%), Önellátás $(19,7 \%)$, Szokásos tevékenységek $(36,1 \%)$ és Szorongás/lehangoltság (30,2\%) dimenziókban, még a -perifériás artériás érbetegségben szenvedő betegek jelentettek leggyakrabban súlyos problémát a Fájdalom/rossz közérzet dimenzióban $(31,1 \%)$. (2. Ábra) 


\section{2. Ábra Az EQ-5D-3L dimenziókban jelentett problémák megoszlása (\%)}
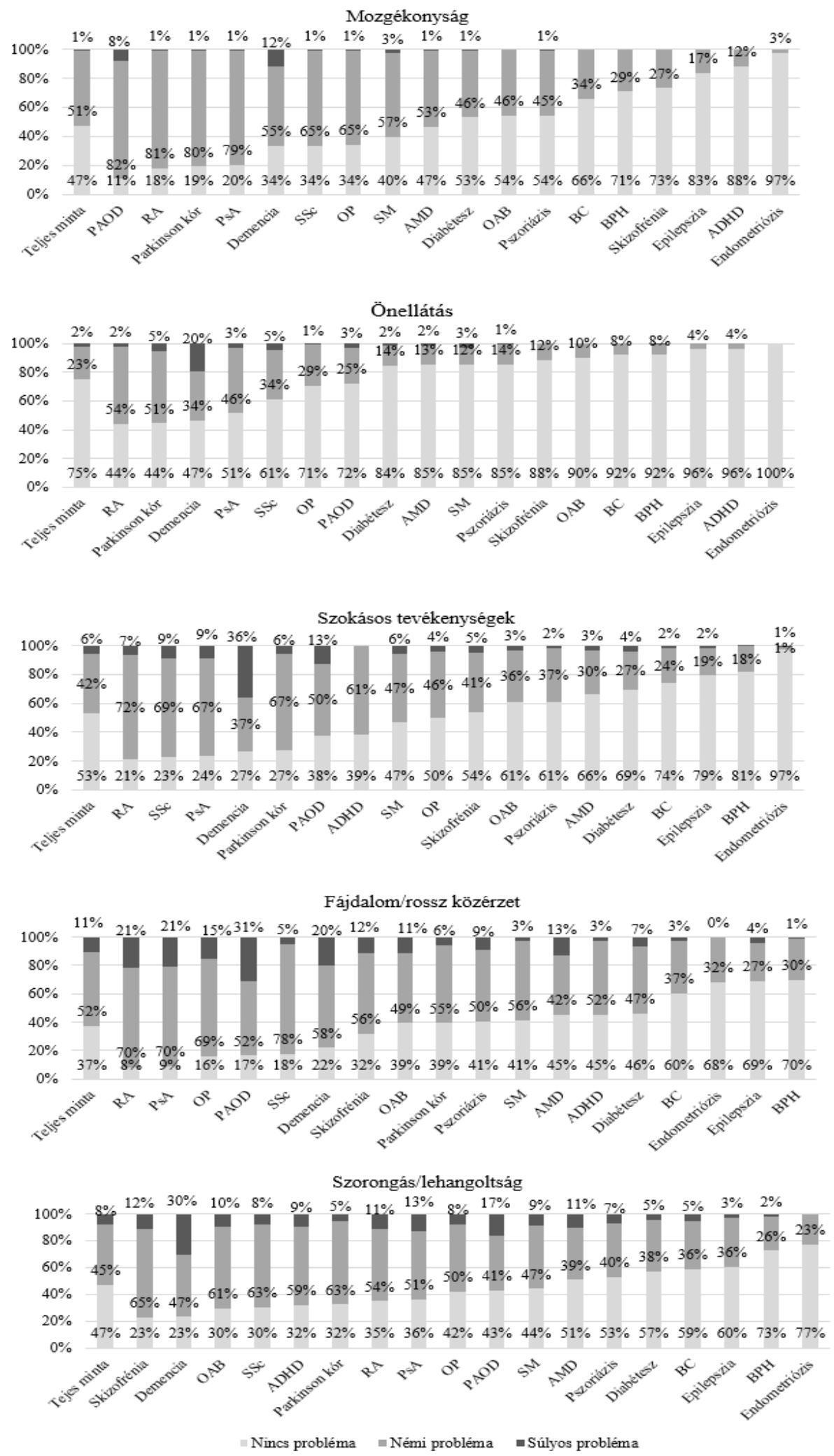

RA: reumatoid artritisz, SSc: szisztémás szklerózis, AP: arthritisz pszoriatika, SM: szklerózis multiplex, AMD: időskori makuladegeneráció, $\mathrm{BPH}$ : jóindulatú prosztata megnagyobbodás, OP: oszteoporózis, $\mathrm{OAB}$ : hiperaktív hólyagszindróma, PAOD: perifériás artériás érbetegség, ADHD: figyelemhiányos hiperaktivitás-zavar, BC: húgyhólyagrák 


\subsubsection{Az értékkészletek összehasonlítása}

Az index értékek EQ-5D-3L dimenziók szerinti összehasonlitása

A 3. Ábra az EQ-5D-3L dimenziók relatív jelentőségét mutatja be a négy értékkészletben. A Szokásos tevékenységek és a Fájdalom/rossz közérzet dimenziókban jelentett súlyos probléma kivételével a lengyel értékkészlet adta a legmagasabb értéket minden dimenzióban jelentett mérsékelt vagy súlyos problémák esetében. A mérsékelt problémák esetében a szlovén, még a súlyos problémák estében a UK értékkészlet jelentette a legalacsonyabb értékeket.

A mérsékelt problémák fennállása miatti teljes egészséghez viszonyított hasznosság veszteség relatív alacsonyabb volt a lengyel és a UK értékkészletek esetében, a súlyos problémák fennállása mellet azonban nagyobb csökkenés volt megfigyelhető. A szlovén értékkészlet esetében a mérsékelt problémák miatt felmerülő hasznosságcsökkenés a jelentősebb, a súlyos problémák miatti kisebb mértékü csökkenés mellett. A teljes egészség és a mérsékelt problémák, valamint a méréskelt és súlyos problémák közötti eltérések hasonlóak voltak az európai értékkészlet esetében.

A legsúlyosabb problémák fennállása esetén ('33333') a UK és a lengyel értékkészletek biztosították a legalacsonyabb értékeket. Az összes lehetséges (243) EQ-5D-3L profilok közül a negatív hasznosság értékkel rendelkező ("halálnál rosszabb”) állapotok előfordulása a UK értékkészlet esetében volt a leggyakoribb (35\%), amelyet a lengyel (3\%), szlovén (9\%) és az európai (2\%) értékkészletek követtek.

A súlyos problémák esetében a lengyel és a UK értékkészletek mutatták a legnagyobb csökkenést a hasznosságban a Fájdalom/rossz közérzet dimenzióban. Ezzel szemben a Mozgékonyság dimenzióban jelentett súlyos probléma rendelkezett a legnagyobb negatív hatással az EQ-5D-3L index értékre a szlovén és az európai értékkészlet használata esetében. Eredményeink alapján arra számítottuk, hogy mind a súlyosság, mind a jelentett probléma helye befolyásolja a négy eltérő értékkészlettel számolt hasznosság értékek különbségeit. (3. Ábra) 


\section{3. Ábra Egészségi állapotok hasznossága a négy EQ-5D-3L értékkészlettel}
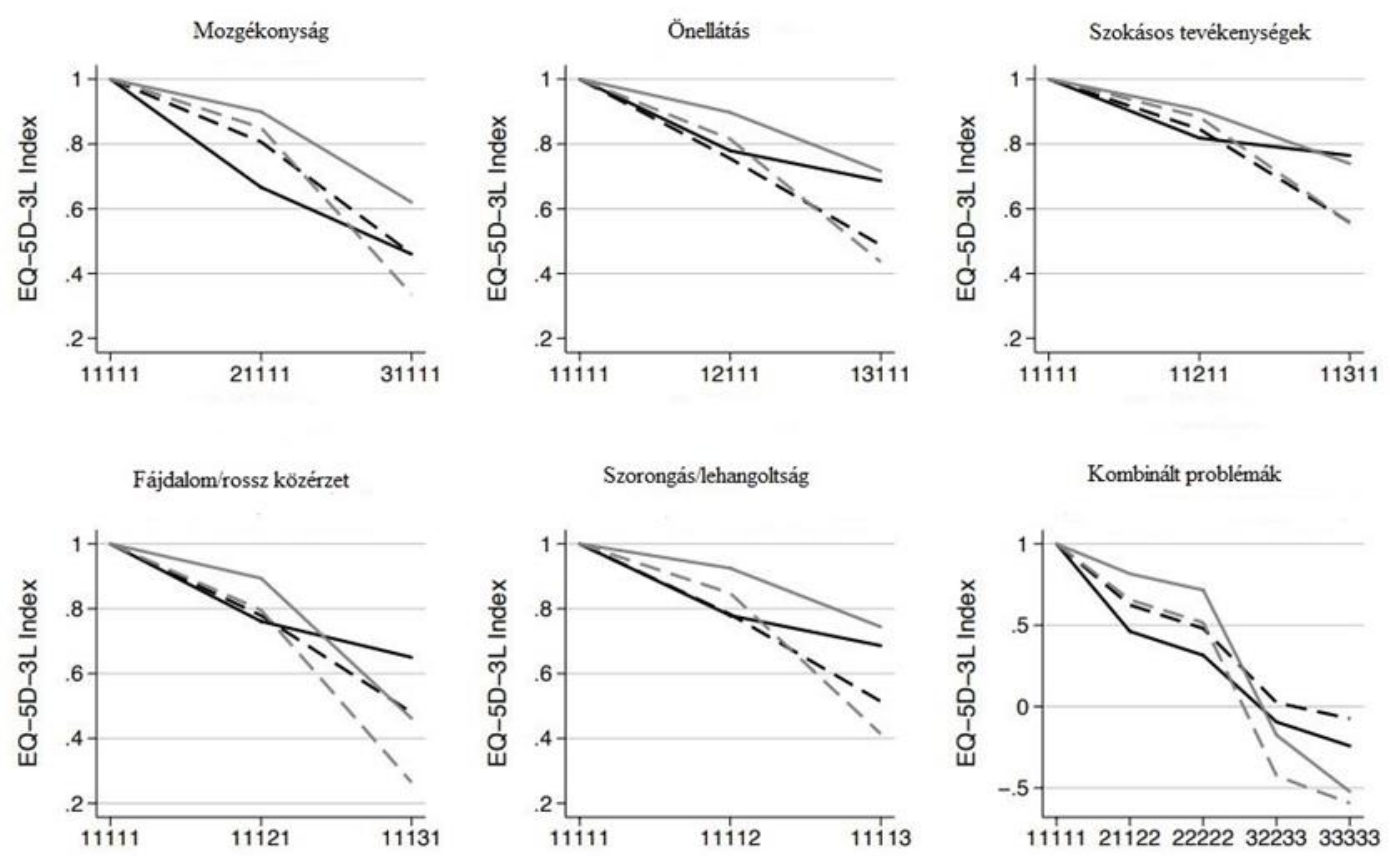

szlovén

európai
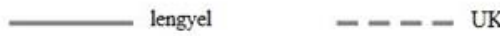

Az értékkészletek diagnózis szerinti összehasonlitása

A diagnózis szerinti elemzősünkhöz kiszámítottuk az EQ-5D-3L index értékeket (átlag, szórás) mind a négy értékkészlettel, minden diagnózisban. Az EQ-5D-3L index érték súlyozott átlaga a teljes mintánkban rendre 0,598 ( $\mathrm{SD}=0,279), 0,661$ $(\mathrm{SD}=0,257), 0,770(\mathrm{SD}=0,261)$ és $0,644(\mathrm{SD}=0,334)$ volt a szlovén, európai, lengyel és UK értékkészletekkel. Minden páronkénti értékkészlet összehasonlítás szignifikáns eredményt mutatott $(\mathrm{p}<0,001)$. (2. Táblázat) 


\section{Táblázat A négy értékkészlettel számolt EQ-5D-3L index értékek diagnózisok szerint (átlag (SD))}

\begin{tabular}{|c|c|c|c|c|c|c|c|c|c|c|}
\hline \multirow[t]{2}{*}{ Diagnózis } & \multicolumn{4}{|c|}{ EQ-5D-3L index érték, átlag (SD) } & \multicolumn{6}{|c|}{ Páros t-próba p-értékek } \\
\hline & SI & $\mathbf{E U}$ & UK & PL & $\begin{array}{l}\text { SI- } \\
\text { EU }\end{array}$ & $\begin{array}{l}\text { SI- } \\
\text { PL }\end{array}$ & $\begin{array}{l}\text { SI- } \\
\text { UK }\end{array}$ & $\begin{array}{l}\text { PL- } \\
\text { UK }\end{array}$ & $\begin{array}{l}\text { PL- } \\
\text { EU }\end{array}$ & $\begin{array}{l}\text { UK- } \\
\text { EU }\end{array}$ \\
\hline Reumatoid artritisz & $0,411(0,217)$ & $0,506(0,235)$ & $0,464(0,334)$ & $0,646(0,270)$ & $<0,001$ & $<0,001$ & $<0,001$ & $<0,001$ & $<0,001$ & $<0,001$ \\
\hline Arthritisz pszoriatika & $0,423(0,230)$ & $0,513(0,244)$ & $0,467(0,347)$ & $0,645(0,288)$ & $<0,001$ & $<0,001$ & 0,002 & $<0,001$ & $<0,001$ & $<0,001$ \\
\hline Szisztémás szklerózis & $0,486(0,240)$ & $0,583(0,218)$ & $0,580(0,285)$ & $0,736(0,234)$ & $<0,001$ & $<0,001$ & $<0,001$ & $<0,001$ & $<0,001$ & 0,770 \\
\hline Oszteoporózis & $0,519(0,242)$ & $0,603(0,233)$ & $0,580(0,319)$ & $0,729(0,258)$ & $<0,001$ & $<0,001$ & $<0,001$ & $<0,001$ & $<0,001$ & 0,002 \\
\hline Epilepszia & $0,804(0,229)$ & $0,826(0,210)$ & $0,831(0,244)$ & $0,900(0,166)$ & 0,001 & $<0,001$ & 0,006 & $<0,001$ & $<0,001$ & 0,384 \\
\hline Szklerózis multiplex & $0,586(0,252)$ & $0,670(0,222)$ & $0,669(0,278)$ & $0,795(0,195)$ & $<0,001$ & $<0,001$ & $<0,001$ & $<0,001$ & $<0,001$ & 0,870 \\
\hline Parkinson kór & $0,476(0,240)$ & $0,583(0,226)$ & $0,588(0,281)$ & $0,741(0,202)$ & $<0,001$ & $<0,001$ & $<0,001$ & $<0,001$ & $<0,001$ & 0,523 \\
\hline Demencia & $0,381(0,288)$ & $0,424(0,286)$ & $0,333(0,430)$ & $0,523(0,405)$ & $<0,001$ & $<0,001$ & 0,023 & $<0,001$ & $<0,001$ & $<0,001$ \\
\hline Figyelemhiányos hiperaktivitás-zavar & $0,697(0,188)$ & $0,727(0,175)$ & $0,735(0,222)$ & $0,846(0,142)$ & $<0,001$ & $<0,001$ & 0,005 & $<0,001$ & $<0,001$ & 0,320 \\
\hline Skizofrénia & $0,626(0,214)$ & $0,658(0,212)$ & $0,644(0,295)$ & $0,778(0,227)$ & 0,002 & $<0,001$ & 0,320 & $<0,001$ & $<0,001$ & 0,261 \\
\hline Endometriózis & $0,880(0,146)$ & $0,888(0,136)$ & $0,902(0,124)$ & $0,950(0,066)$ & 0,001 & $<0,001$ & $<0,001$ & $<0,001$ & $<0,001$ & $<0,001$ \\
\hline Jóindulatú prosztata megnagyobbodás & $0,792(0,228)$ & $0,838(0,181)$ & $0,852(0,187)$ & $0,913(0,114)$ & $<0,001$ & $<0,001$ & $<0,001$ & $<0,001$ & $<0,001$ & $<0,001$ \\
\hline Hiperaktív hólyagszindróma & $0,611(0,256)$ & $0,678(0,227)$ & $0,668(0,314)$ & $0,787(0,253)$ & $<0,001$ & $<0,001$ & 0,005 & $<0,001$ & $<0,001$ & 0,489 \\
\hline Pszoriázis & $0,647(0,271)$ & $0,706(0,246)$ & $0,694(0,310)$ & $0,808(0,226)$ & $<0,001$ & $<0,001$ & $<0,001$ & $<0,001$ & $<0,001$ & 0,056 \\
\hline Húgyhólyagrák & $0,729(0,236)$ & $0,775(0,205)$ & $0,784(0,242)$ & $0,874(0,152)$ & $<0,001$ & $<0,001$ & $<0,001$ & $<0,001$ & $<0,001$ & 0,051 \\
\hline Diabétesz & $0,665(0,276)$ & $0,728(0,243)$ & $0,723(0,295)$ & $0,826(0,220)$ & $<0,001$ & $<0,001$ & $<0,001$ & $<0,001$ & $<0,001$ & 0,350 \\
\hline Perifériás artériás érbetegség & $0,413(0,252)$ & $0,508(0,274)$ & $0,426(0,411)$ & $0,589(0,359)$ & $<0,001$ & $<0,001$ & 0,527 & $<0,001$ & $<0,001$ & $<0,001$ \\
\hline Időskori makuladegeneráció & $0,622(0,262)$ & $0,679(0,250)$ & $0,657(0,334)$ & $0,780(0,246)$ & $<0,001$ & $<0,001$ & 0,013 & $<0,001$ & $<0,001$ & 0,020 \\
\hline Teljes minta* & $0,598(0,279)$ & $0,661(0,257)$ & $0,644(0,334)$ & $0,770(0,261)$ & $<0,001$ & $<0,001$ & $<0,001$ & $<0,001$ & $<0,001$ & $<0,001$ \\
\hline
\end{tabular}

EU: európai; PL: lengyel; SI:szlovén; UK:Egyesült Királyság értékkészlete

*Súlyozott átlag értékek 
Az endometriózisban szenvedő betegek rendelkeztek a legmagasabb, még a demenciában szenvedők a legalacsonyabb átlagos EQ-5D-3L index értékkel mind a négy értékkészlettel. A két érték közötti legnagyobb különbséget Parkinson kór diagnózisban találtuk a szlovén és a lengyel értékkészlettel számolt indexértékek között találtuk $(0,265)$. A négy értékkészlet páronkénti t-teszttel történő összehasonlítása szignifikáns eltéréseket mutattak a legtöbb diagnózisban. Skizofréniában a UK értékkészlet nem tért el szignifikánsan a szlovén és az európai értékkészlettől. A többi diagnózisban 5 vagy 6 páronkénti összehasonlítás mutatott szignifikáns eltéréseket. A UK és az európai értékkészlet nem tért el szignifikánsan 10, a UK és a szlovén pedig 2 diagnózisban a 18 diagnózis közül. Minden más összehasonlítás szignifikáns eltérést mutatott az összes diagnózisban.

Az értékkészletek összehasonlitása a betegek szubjektív egészségi állapotának értékelése szerint

Megvizsgáltuk, hogy a betegségsúlyosság hogyan befolyásolta az értékkészletek közötti eltéréseket. A betegségsúlyosság kifejezésére az EQ VAS által mért szubjektív értékelést használtuk. Három jól elkülöníthető EQ VAS „területet” tudtunk azonosítani az értékkészletek eltéréseinek mintái szerint. (4. Ábra) A lengyel értékkészlettel meghatározott index értékek voltak a legmagasabbak a teljes EQ VAS tartományban. A legnagyobb (négy értékkészlet közötti) különbséget a 40 és 80 közötti EQ VAS tartományban találtuk $(n=437,61,7 \%)$. Ebben a tartományban a szlovén index értékek voltak a legalacsonyabbak, még az európai és UK szinte egyező értéket adott. A legkisebb eltéréseket a 80 és 100 közötti EQ VAS tartományban találtuk ( $\mathrm{n}=437,20,4 \%)$, valamint az értékkészletek által mutatott minta a 40 alatti EQ VAS tartományban ( $\mathrm{n}=437,17,9 \%)$ mutatott eltérést, ahol a szlovén és a lengyel értékkészletek konvergáltak, a UK értékkészlet pedig a legalacsonyabb értékeket mutatta. (4. Ábra) 


\section{4. Ábra Az értékkészletek a beteg szubjektív egészség értékelése szerinti összehasonlítása}

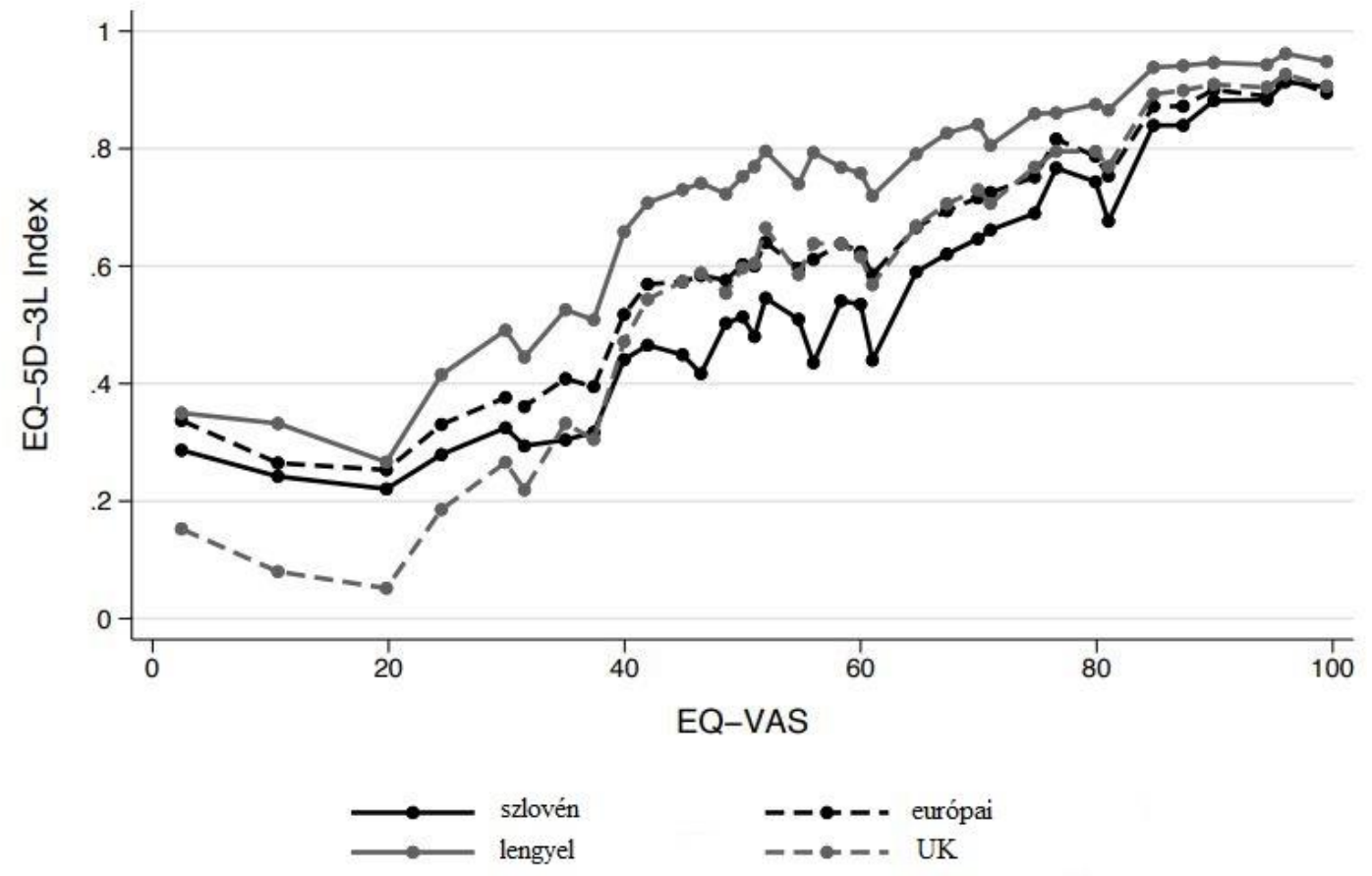

Az értékkészletek összehasonlitása az eltérö életkor szerinti csoportokban

Szintén elemezni kívántuk, hogy a négy eltérö értékkészlettel számolt EQ-5D-3L index értékek eltéréseit mennyiben befolyásolta a beteg életkora. Három korcsoportot különítettük el: 18-34, 35-54 és 55 év felettiek. A 2421 betegböl 16,3\% tartozott a legfiatalabb ( $\mathrm{n}=275), 26,7 \%$ a középső $(\mathrm{n}=609)$ és $56,6 \%(\mathrm{n}=1525)$ a legidősebb korcsoporthoz.

A betegek több mint fele tartozott a legfiatalabb korcsoportba figyelemhiányos hiperaktivitás-zavar (69,3\%), endometriózis $(64,6 \%)$ és epilepszia $(54,2 \%)$ esetében. Egyes betegségekben, amelyek tipikusan az idősebb lakosságot érintik, a betegek többsége 55 év feletti volt: 100\% időskori makuladegenerációban, 96,5\% demenciában, 95,8\% jóindulatú prosztata megnagyobbodásban, 95,2\% perifériás artériás érbetegségben és 93,7\% oszteoporózisban. A szlovén, európai, lengyel és UK index értékek rendre 0,765 $(\mathrm{SD}=0,214), 0,793(\mathrm{SD}=0,190), 0,886(\mathrm{SD}=0,140)$ és $0,804(\mathrm{SD}=0,213)$ voltak a $18-34$ éves csoportban, 0,601 ( $\mathrm{SD}=0,277), 0,662(\mathrm{SD}=0,255), 0,773(\mathrm{SD}=0,251)$ és 0,644 
$(\mathrm{SD}=0,329)$ a $35-54$ éves korcsoportban, valamint $0,548(\mathrm{SD}=0,277), 0,622(\mathrm{SD}=0,262)$, $0,735(\mathrm{SD}=0,281)$ és $0,598(\mathrm{SD}=0,350)$ az 55 év feletti csoportban. Minden értékkészlet összehasonlítás szignifikáns eltérést mutatott $(\mathrm{p} \leq 0,001)$.

Minden életkor szerinti csoportban a szlovén értékkészlettel számított érték volt a legalacsonyabb, a lengyel értékkészlet pedig a legmagasabb. A legfiatalabb és legidősebb korcsoport közötti eltérés a szlovén értékkészlettel volt a legmagasabb $(0,217)$, ezt követte a UK $(0,206)$, az európai $(0,171)$ és a lengyel $(0,150)$ értékkészlet. Minden életkor-csoport szerinti összehasonlítás szignifikáns eredményt mutatott $(\mathrm{p}<0,001)$.

A betegségteher elemzés értékkészletválasztásra való érzékenysége

Annak ellenére, hogy a brit TTO módszeren alapuló értékkészlet kerül leggyakrabban használatra mind Magyarországon, mind a Közép-Kelet-Európai régióban (Rencz et al., 2016, Rencz et al., 2015d), fel kívántuk mérni, hogy a betegségteher mérést mennyiben befolyásolja az értékkészlet megválasztása a 18 vizsgált diagnózisban. (5. Ábra)

Pozitív és negatív irányú eltéréseket is megfigyeltünk egyes diagnózisokban mind a négy értékkészlet esetében, különösképpen a szlovén és a UK értékkészletek eltérései voltak kimagaslóak. Demencia esetében 0,15-tel alacsonyabb, még szklerózis multiplex és Parkinson kór esetében 0,05 ponttal magasabb értékeket kapunk, ha a UK helyett a szlovén értékkészletet használjuk. A lengyel értékek eltértek a brit értékektől arthritisz pszoriatika diagnózisban, az európaiaktól pedig demenciában. A lengyel és a azlovén értékkészletek eltérései szintén jelentősek voltak szklerózis multiplex és Parkinson kór diagnózisokban. Az értékkészletek nagyon hasonló értékeket eredményeztek diabétesz, epilepszia, hiperaktív hólyagszindróma és oszteoporózis diagnózisokban. 


\section{5. Ábra A UK értékkészlettől való eltérések (DB) (EQ-5D-3L index érték eltérésekben kifejezve)}

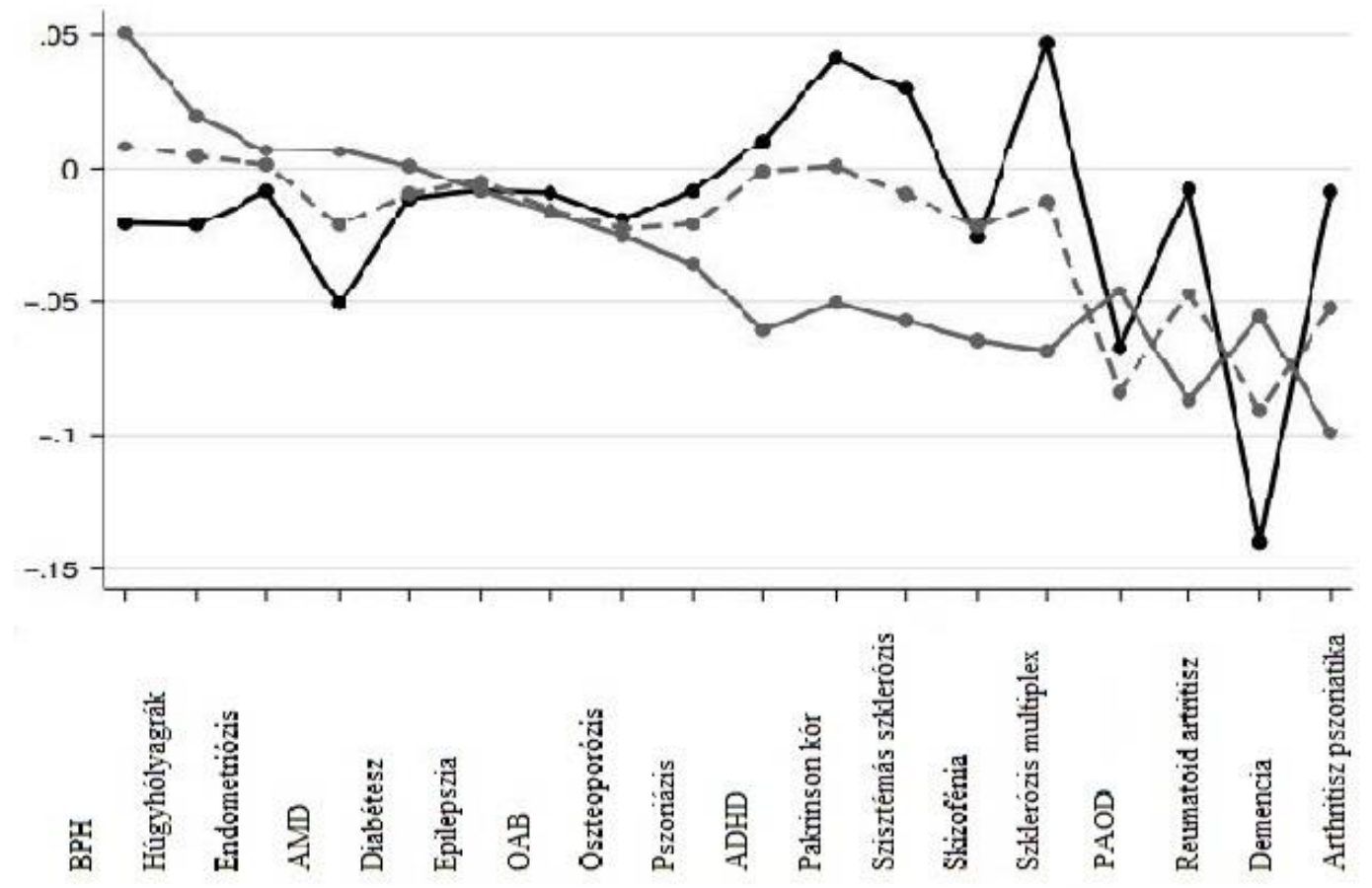

Diagnózis

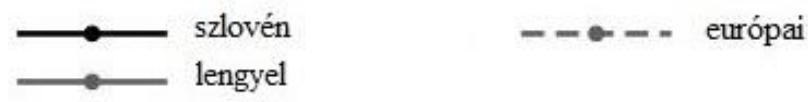

BPH: jóindulatú prosztata megnagyobbodás, AMD: időskori makuladegeneráció, OAB: hiperaktív hólyagszindróma, ADHD: figyelemhiányos hiperaktivitás-zavar, PAOD: perifériás artériás érbetegség

$\mathrm{Az}$ értékkészlet választás szenzitivitásának értékélésére a "sensitivity index"-et használtuk. (3. Táblázat) Összesen 153 páronkénti összehasonlítást végeztünk el a 18 diagnózisban ( $\mathrm{n}=18 * 17 / 2), 22.9 \%$ mutatott változatos eredményeket. A nem szignifikáns eltérések és szignifikáns eltérések (valamely irányba) kombinációi jelentették a legnagyobb eltéréseket. Legfőképpen a diagnózis szerinti mintáink alacsony elemszáma miatt nem találtunk olyan páronkénti összehasonlítást, amelyben alternatív értékkészletek statisztikailag szignifikáns, eltérő rangsorhoz vezettek volna (+ $\triangle D B$ adott értékkészlettel, de - valamely másikkal). A "sensitivity index" eredmények arra utalnak, hogy az eltérö betegségek nem egyforma mértékben érzékenyek az értékkészlet választásra. A demencia, szklerózis multiplex és perifériás artériás érbetegség diagnózisok esetében a 
kimenetelek nagyban függtek az értékkészlet választástól, azonban más diagnózisokban (mint például a jóindulatú prosztata megnagyobbodás vagy a húgyhólyagrák) az eredményeket nem befolyásolta jelentősen az értékkészlet választás. 


\section{Táblázat A betegségteher összehasonlítása a négy értékkészlettel, diagnózisok szerint ("sensitivity index")}

\begin{tabular}{|c|c|c|c|c|c|c|c|c|}
\hline \multirow{2}{*}{ Betegség } & \multirow{2}{*}{$\begin{array}{c}\text { Összehasonlítások } \\
\text { száma }\end{array}$} & \multicolumn{7}{|c|}{ Paronkénti DB*eltérések ... } \\
\hline & & Négy értékkészlet ${ }^{\mathrm{a}}$ & EU vs. PL $^{\mathrm{c}}$ & EU vs. SI ${ }^{\mathbf{c}}$ & EU vs. $\mathbf{U K}^{\mathrm{c}}$ & SI vs. PL ${ }^{c}$ & SI vs. UK ${ }^{\mathrm{c}}$ & PL vs. UK $^{\mathrm{c}}$ \\
\hline Reumatoid artritisz & 17 & 0,118 & 0,059 & 0,000 & 0,059 & 0,118 & 0,118 & 0,000 \\
\hline Arthritisz pszoriatika & 17 & 0,176 & 0,118 & 0,000 & 0,118 & 0,118 & 0,118 & 0,000 \\
\hline Szisztémás szklerózis & 17 & 0,294 & 0,294 & 0,000 & 0,176 & 0,294 & 0,176 & 0,118 \\
\hline Oszteoporózis & 17 & 0,235 & 0,235 & 0,000 & 0,118 & 0,235 & 0,118 & 0,118 \\
\hline Epilepszia & 17 & 0,118 & 0,059 & 0,000 & 0,000 & 0,059 & 0,118 & 0,059 \\
\hline Szklerózis multiplex & 17 & 0,412 & 0,235 & 0,059 & 0,059 & 0,412 & 0,235 & 0,176 \\
\hline Parkinson kór & 17 & 0,294 & 0,294 & 0,000 & 0,294 & 0,294 & 0,294 & 0,000 \\
\hline Demencia & 17 & 0,412 & 0,235 & 0,118 & 0,235 & 0,412 & 0,412 & 0,000 \\
\hline Figyelemhiányos hiperaktivitás-zavar & 17 & 0,294 & 0,294 & 0,000 & 0,294 & 0,294 & 0,294 & 0,000 \\
\hline Skizofrénia & 17 & 0,294 & 0,294 & 0,000 & 0,118 & 0,235 & 0,059 & 0,176 \\
\hline Endometriózis & 17 & 0,176 & 0,118 & 0,059 & 0,000 & 0,118 & 0,118 & 0,118 \\
\hline Jóindulatú prosztata megnagyobbodás & 17 & 0,000 & 0,000 & 0,000 & 0,000 & 0,000 & 0,000 & 0,000 \\
\hline Hiperaktív hólyagszindróma & 17 & 0,294 & 0,294 & 0,000 & 0,235 & 0,294 & 0,235 & 0,059 \\
\hline Pszoriázis & 17 & 0,294 & 0,235 & 0,118 & 0,235 & 0,235 & 0,235 & 0,000 \\
\hline Húgyhólyagrák & 17 & 0,059 & 0,000 & 0,059 & 0,000 & 0,059 & 0,059 & 0,000 \\
\hline Diabétesz & 17 & 0,118 & 0,059 & 0,000 & 0,000 & 0,118 & 0,059 & 0,059 \\
\hline Perifériás artériás érbetegség & 17 & 0,353 & 0,353 & 0,000 & 0,235 & 0,353 & 0,235 & 0,118 \\
\hline Időskori makuladegeneráció & 17 & 0,176 & 0,059 & 0,118 & 0,059 & 0,176 & 0,176 & 0,000 \\
\hline Teljes minta & 153 & $0,229^{b}$ & $0,180^{\mathrm{d}}$ & $0,029^{\mathrm{d}}$ & $0,124^{\mathrm{d}}$ & $0,212^{\mathrm{d}}$ & $0,170^{\mathrm{d}}$ & $0,056^{\mathrm{d}}$ \\
\hline
\end{tabular}

*DB: betegségteher (disease burden), ${ }^{\mathrm{a}} 17 \mathrm{x} 4$ DB összehasonlítás alapján ${ }^{\mathrm{b}} 153 \times 4$ DB összehasonlítás alapján ${ }^{\mathrm{c}} 17 \mathrm{x} 2$ DB összehasonlítás alapján ${ }^{\mathrm{d}} 153 \times 2$ DB összehasonlítás alapján EU: európai; PL: lengyel; SI:szlovén; UK:Egyesült Királyság értékkészlete, 


\subsubsection{A DLQI kérdőív „nem releváns” válaszainak részletes elemzése}

\subsubsection{A betegpopuláció jellemzői}

A pszoriázisban szenvedő betegek $(\mathrm{n}=428)$ átlagéletkora 49,2 $(\mathrm{SD}=14,3)$ év volt és a betegek $65 \%$ volt férfi. A betegek közel egyharmada rendelkezett felsőfokú végzettséggel és kevesebb, mint egyharmada végzett teljes munkaidős munkát. A férfi betegek nagyobb arányban végeztek fizetett munkát $(62,6 \%$ vs. $44,7 \%, p<0,001)$, azonban az iskolázottság tekintetében nem volt szignifikáns eltérés a nemek között. Az átlagos betegségfennállási idő rendre 19,9 és 12,3 év volt. A betegek több mint 80\%-a mérsékelt-súlyos pszoriázisban szenvedett, és a betegek többsége (43,7\%) biológiai terápiát kapott, még $25 \%$ szisztémás, nem biológiai és $24,1 \%$ pedig csak helyi kezelést kapott. Összesen 31 beteg $(7,2 \%)$ nem kapott semmilyen kezelést a kutatás idejében, többségük PASI értéke 10 feletti volt és a szisztémás terápia megkezdése előtt álltak.

\subsubsection{A „nem releváns” válaszok részletes elemzése}

A sport (6), szexuális nehézségek (9) és munka vagy tanulás (7) tételek esetében 28,4\%, $16,4 \%$ és $14 \%$ választotta a NRR választ rendre. Kevesebb, mint 3\% jelölte meg a NRR választ a ruházat (4), kezelés nehézségei (10) és a társasági események (5) esetében. (6. Ábra) 


\section{6. Ábra A “nem releváns” válaszok megoszlása az egyes DLQI kérdésekben (\%)}

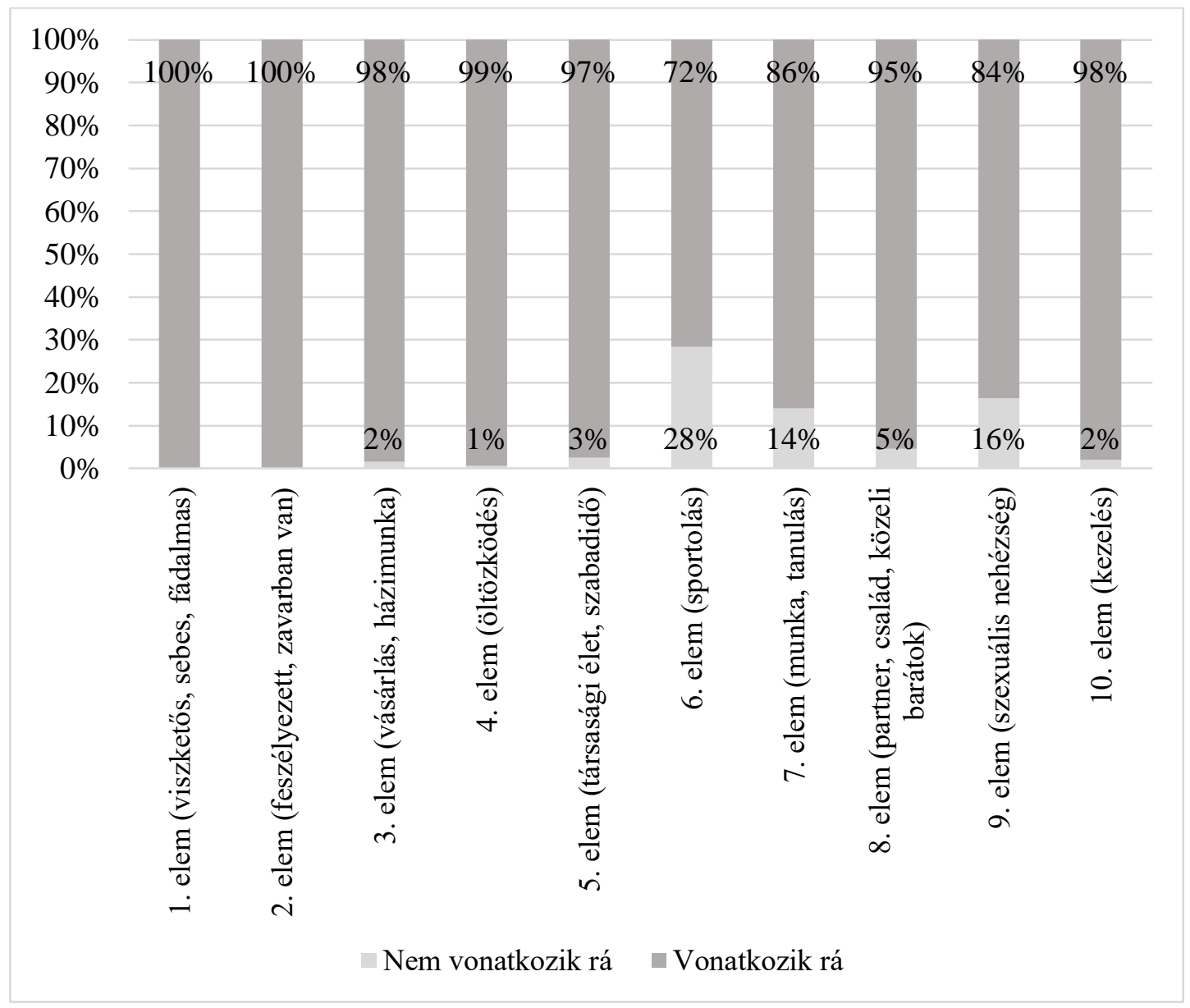

A 238 beteg közül 38,8\% (n=166) jelölt meg legalább egy NRR választ. Ebből 84 fö $(19,6 \%)$ egy NRR választ, 49 (11,5\%) két NRR választ, 22 (5,1\%) 3 NRR választ, 7 beteg $(1,6 \%) 4$ NRR választ, 1 fó $(0,2 \%) 5$ NRR választ, 2 beteg $(0,5 \%) 6$ NRR választ és egy beteg $(0,2 \%)$ nyolc NRR választ jelölt meg. A 6. elemet (sport) jelölte meg az $1 \mathrm{db}$ NRR választ jelölők többsége 61,9\%).

A 0 vagy 1 DLQI pontszámmal rendelkező betegek közül 28\% rendelkezett legalább egy NRR válasszal. A 2-5, 6-10 és 11-20 DLQI pontszámmal rendelkező betegek közül rendre 38\%, 52\% és 53\% rendelkezett NRR válasszal. A 21 feletti pontszámmal rendelkező betegek esetében 13\% volt az NRR válasszal rendelkezők száma. (7. Ábra) 


\section{7. Ábra A “nem releváns” válaszok megoszlása DLQI pontszám szerint (\%)}

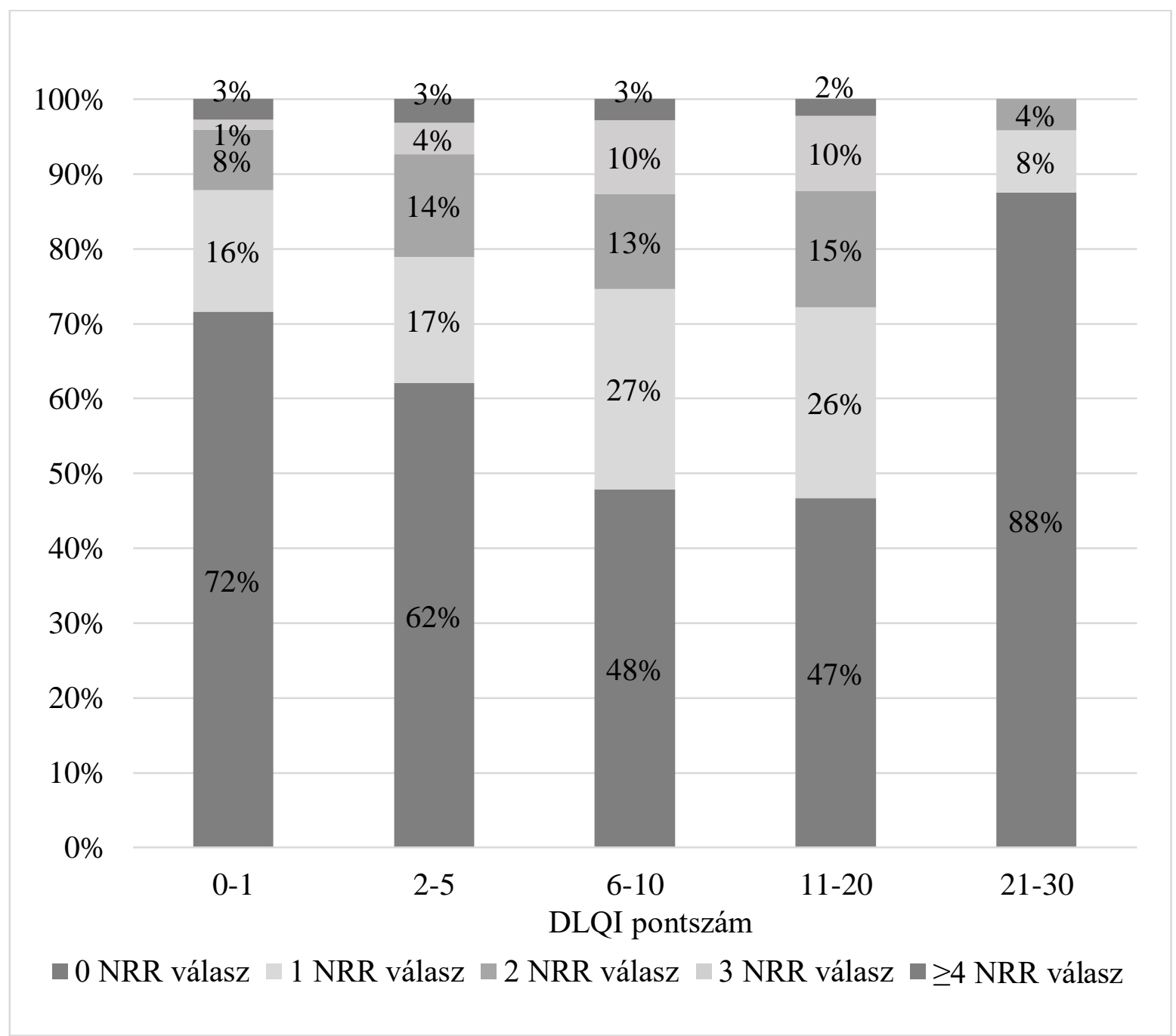

6.1.2.3. A „nem releváns” válaszok magyarázó tényezői

Az 1, 2 és 3 NRR válasszal rendelkező betegek DLQI pontszámának átlaga rendre 6,5, 7,2 és 7,3 volt $(\mathrm{p}=0,049)$. Többváltozós, logisztikus regressziós modellünkben számos szocio-demográfiai és klinikai tényező mutatott szignifikáns hatást a NRR válaszokra. A nők nagyobb valószínüséggel választottak NRR választ. A közép vagy felsőfokú iskolázottság fennállása viszont csökkentette a NRR válaszok adásának valószínüségét. A teljes munkaidőben foglalkoztatott válaszadók kisebb valószínüséggel választották az NRR válaszlehetőségét. Továbbá a magasabb életkor és PASI érték volt a NRR válaszok előfordulásához magasabb valószínűségéhez köthető. (4. Táblázat) 


\section{Táblázat Többváltozós, logisztikus regressziós modell}

\begin{tabular}{|l|r|r|r|r|}
\hline Változók & $\begin{array}{r}\text { Regressziós } \\
\text { együttható }\end{array}$ & \multicolumn{1}{|c|}{ SE } & \multicolumn{1}{c|}{$\begin{array}{c}\text { Odds Ratio } \\
\text { (95\% konfidencia } \\
\text { intervallum) }\end{array}$} & $\begin{array}{c}\text { p } \\
\text { érték }\end{array}$ \\
\hline Konstans & $-1,668$ & 0,599 & 0,189 & 0,005 \\
\hline Nem (nö) & 0,498 & 0,235 & $1,646(1,039-2,608)$ & 0,034 \\
\hline Életkor (év) & 0,048 & 0,009 & $1,049(1,031-1,068)$ & 0,000 \\
\hline PASI pont & 0,030 & 0,012 & $1,030(1,006-1,055)$ & 0,014 \\
\hline Iskolázottság & $-0,905$ & 0,337 & $0,405(0,209-0,784)$ & 0,007 \\
\hline Középfokú & $-0,071$ & 0,377 & $0,343(0,164-0,717)$ & 0,004 \\
\hline Felsőfokú & $-0,746$ & 0,250 & $0,474(0,290-0,774)$ & 0,003 \\
\hline Teljes munkaidőben dolgozik & \multicolumn{5}{|l}{} \\
\hline n=428, eredményváltozó: 0 NRR válasz="0", legalább 1 NRR válasz="1"
\end{tabular}

\subsubsection{A magyarországi lakosság egészségi állapota és munkaképessége}

\subsubsection{A minta jellemzői}

Összesen 2023 válaszadó vett részt a vizsgálatban, a válaszadók 50,1\%-a $(\mathrm{n}=1013)$ volt nő. Az átlagéletkor 48,7 év ( $\mathrm{SD}=17,9)$ volt. A válaszadók 41,7\%-a rendelkezett alapfokú, 38,1\%-a középfokú és 20,2\%-a felsőfokú végzettséggel. A válaszadók 19,7\%-a élt Budapesten, 52,5\% más városban és 27,8\% községekben. A kitöltő személyek háztartása átlagosan 2,5 $(\mathrm{SD}=1,3)$ taglétszámmal rendelkezett és a háztartás egy före jutó havi bevétele átlagosan 128000 HUF volt (SD=60 000 HUF).

6.1.3.2. Egészségi állapot

$E Q-5 D-5 L$

Az EQ-5D-5L index érték átlaga $0,92(\mathrm{SD}=0,15)$ volt. A legtöbb problémát a Fájdalom/rossz közérzet dimenzióban jelentették a válaszadók: 31,6\% jelölte meg 
valamilyen szintű probléma fennállását ebben a dimenzióban. Az EQ-VAS átlaga 81,6 $(\mathrm{SD}=17,4)$ volt a résztvevők körében. (6. Táblázat)

A férfiak kevesebb problémáról számoltak be, mint a nők, az Önellátás dimenzió kivételével, amelyben rendre $9,9 \%$ és $8,9 \%$ jelölt valamilyen szintü problémát. A válaszadók átlagos EQ-5D-5L indexe és EQ VAS pontszáma 0,92 $(\mathrm{SD}=0,15)$ és 81,6 $(\mathrm{SD}=17,4)$ volt.

MEHM

A válaszadók 20,6\%-a jelenlegi egészségi állapotát „Nagyon jó”-nak értékelte, és mindösszesen 18 válaszadó $(0,9 \%)$ nyilatkozta, hogy az egészségi állapota „Nagyon rossz”. Legalább 6 hónapig fennálló krónikus betegsége vagy egészségi problémája a válaszadók 31,4\%-ának volt ( $\mathrm{n}=635$ fö). A válaszadók többségét ( $80,4 \%, \mathrm{n}=1627$ fö) nem korlátozta legalább 6 hónapja fennálló egészségi problémája, és 3,2\%-uk ( $n=65$ fö) jelölte, hogy egészségi problémája súlyosan korlátozza mindennapi tevékenységei során. (5. Táblázat)

5. Táblázat A válaszadók jelen egészségi állapota (MEHM), N=2023

\begin{tabular}{|l|r|}
\hline Minimum European Health Module & \multicolumn{1}{|c|}{$\mathrm{n}(\%)$} \\
\hline Jelen egészségi állapota & $417(20,6 \%)$ \\
\hline Nagyon jó & $916(45,3 \%)$ \\
\hline Jó & $545(26,9 \%)$ \\
\hline Kielégítő & $127(6,3 \%)$ \\
\hline Rossz & $18(0,9 \%)$ \\
\hline Nagyon rossz & $635(31,4 \%)$ \\
\hline Legalább 6 hónapig fennálló krónikus betegsége vagy egészségi problémája \\
\hline Van & $1381(68,8 \%)$ \\
\hline Nincs & $7(0,3 \%)$ \\
\hline Nem tudom/nem kívánok válaszolni & $65(3,2 \%)$ \\
\hline Legalább 6 hónapja fennálló egészségi probléma & $329(16,3 \%)$ \\
\hline Súlyosan korlátozza & $1627(80,4 \%)$ \\
\hline Korlátozza, de nem súlyosan & $2(0,1 \%)$ \\
\hline Nem korlátozza & \\
\hline Nem tudom/nem kívánok válaszolni & \\
\hline
\end{tabular}




\subsubsection{Munkaképesség}

A résztvevők medián 40 órát (minimum-maximum: 0-100) órát dolgoztak a kérdőív kitöltését megelőző héten és egészségügyi okok miatti hiányzásuk óraszáma 0 óra mediánnal rendelkezett. A hiányzott órák maximuma 60 óra volt (minimum: 0 óra). Az egészségügyi gondok medián 0 (minimum-maximum: 0-10) mértékben befolyásolták munkavégzés közben a válaszadót. Az absenteeism és a presenteeism és az összesített termelékenységveszteség munkavégzés közben egyaránt medián 0 volt.

A foglalkoztatottságra vonatkozó kérdésre 1259 fó válaszolta, hogy teljes- vagy részmunkaidőben dolgozik. A WPAI kérdőív első kérdésére adott válaszok alapján 1232 válaszadó volt fizetett munkaviszonyban a kérdőíves felméréskor, a 27 fő eltérés az eltérő kérdésfeltevésből adódhat (pl. ha az egyéni vállalkozó azt jelölte meg, hogy nem fizetett munkaviszonyban van). A munkavégzéssel kapcsolatos elemzésekhez a WPAI kérdőív alapján az 1232 fő válaszait vettük alapul.

Továbbá kizárásra került további 4 válaszadó, mert a lehetséges fizetett munkavégzés óraszámát heti 100 órában maximáltuk. További 32 fố nem dolgozott az elmúlt héten, de nem egészségügyi okokból. Két fô hiányos válaszadás miatt került kizárásra (nem töltötték ki a munkavégzés közbeni akadályozottságra vonatkozó kérdést, de dolgoztak az elmúlt héten). A fizetett munkavégzésre vonatkozó elemzéseinket 1194 válaszadó bevonásával elemeztük. Közülük 25 fö nem dolgozott, ezért a munkavégzés közben tapaszt termelékenység csökkenést 1169 fö esetében elemeztük.

A WPAI más tevékenységekben aktivitás csökkenés átlagos értéke 9,5\% ( $\mathrm{SD}=21,0 \%)$, még az összesített termelékenységveszteség munkavégzés közben átlagos értéke 7,7\% $(\mathrm{SD}=20,9 \%)$ volt. $\mathrm{Az}$ absenteeism és a presenteeism esetében az átlagos értékek 3,6\% $(16,4 \%)$ és $4,4 \%(14,2 \%)$ voltak rendre. Nemek szerint nem találtunk szignifikáns eltéréseket, hasonló értékeket találtunk a nők és férfiak esetében mind a négy változóban. Korcsoportok szerint szignifikáns eltérést találtunk a más tevékenységekben aktivitás csökkenés átlagos értéke, az összesített termelékenységveszteség munkavégzés közben és a preseteeism között ( $\mathrm{p}=0,000$, minden esetben). (6. Táblázat) 
6. Táblázat A válaszadók szocio-demográfiai jellemzői, egészségi állapota és munkaképessége

\begin{tabular}{|c|c|c|c|c|c|c|c|c|c|}
\hline \multirow[t]{2}{*}{ Változók } & \multirow[t]{2}{*}{$\mathbf{N}(\%)$} & \multirow{2}{*}{$\begin{array}{c}\text { EQ VAS, } \\
\text { N=2023 } \\
\text { Átlag (SD) }\end{array}$} & \multirow{2}{*}{ 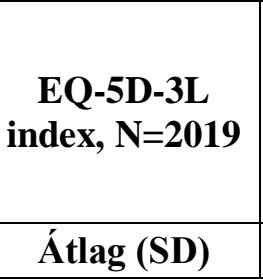 } & \multirow{2}{*}{\begin{tabular}{|c|} 
WPAI, más \\
tevékenységekben \\
aktivitás \\
csökkenés, \% \\
N=2023 \\
Átlag (SD) \\
\end{tabular}} & \multicolumn{2}{|c|}{$\begin{array}{c}\text { WPAI, absenteeism, \% } \\
\text { N=1194 }\end{array}$} & \multirow{2}{*}{$\begin{array}{c}\begin{array}{c}\text { WPAI összesített } \\
\text { termelékenység- } \\
\text { veszteség \% N=1194 }\end{array} \\
\text { Átlag (SD) }\end{array}$} & \multicolumn{2}{|c|}{$\begin{array}{c}\text { WPAI presenteeism, \%, } \\
\text { N=1169 }\end{array}$} \\
\hline & & & & & $\mathbf{N}(\%)$ & Átlag (SD) & & $\mathbf{N}(\%)$ & Átlag (SD) \\
\hline Teljes minta & $2023(100 \%)$ & $0,877(0,204)$ & $81,6(17,4)$ & $9,5(21,0)$ & $1194(100 \%)$ & $3,6(16,4)$ & $7,7(20,9)$ & $1169(100 \%)$ & $4,4(14,2)$ \\
\hline Neme & & $\mathrm{p}=0,857$ & $\mathrm{p}=0,012$ & $\mathrm{p}=0,222$ & & $\mathrm{p}=0,448$ & $\mathrm{p}=0,651$ & & $\mathrm{p}=0,879$ \\
\hline férfi & $1010(49,9 \%)$ & $81,6(17,4)$ & $0,886(0,201)$ & $8,9(20,2)$ & $614(51,4 \%)$ & $4,1(17,3)$ & $8,0(21,2)$ & $600(51,3 \%)$ & $4,3(1,3,7)$ \\
\hline nö & $1013(50,1 \%)$ & $81,6(17,4)$ & $0,868(0,207)$ & $10,2(21,8)$ & $580(48,5 \%)$ & $3,1(15,4)$ & $7,3(20,6)$ & $569(48,7 \%)$ & $4,7(15,5)$ \\
\hline Korcsoport & & $\mathrm{p}=0,000$ & $\mathrm{p}=0,000$ & $\mathrm{p}=0,000$ & & $\mathrm{p}=0,983$ & $\mathrm{p}=0,000$ & & $\mathrm{p}=0,000$ \\
\hline 18-24 éves & $208(10,3 \%)$ & $92,6(10,3)$ & $0,923(0,100)$ & $1,8(9,6)$ & $111(9,3 \%)$ & $4,1(16,7)$ & $6,0(20,4)$ & $109(9,3 \%)$ & $2,4(12,9)$ \\
\hline 25-34 éves & $308(15,2 \%)$ & $90,7(11,5)$ & $0,957(0,117)$ & $3,3(14,0)$ & $249(21,7 \%)$ & $3,7(17,2)$ & $7,5(22,4)$ & $243(20,8 \%)$ & $4,3(16,1)$ \\
\hline 35-44 éves & $387(19,1 \%)$ & $86,5(13,6)$ & $0,928(0,174)$ & $4,2(13,9)$ & $329(27,6 \%)$ & $3,2(15,0)$ & $6,9(19,4)$ & $324(27,7 \%)$ & $4,0(13,2)$ \\
\hline 45-54 éves & $333(16,5 \%)$ & $85,1(14,1)$ & $0,925(0,159)$ & $5,3(16,0)$ & $296(24,8 \%)$ & $3,7(16,7)$ & $7,4(20,6)$ & $289(24,7 \%)$ & $3,9(13,0)$ \\
\hline 55-64 éves & $334(16,5 \%)$ & $76,6(17,6)$ & $0,856(0,201)$ & $11,7(22,5)$ & $190(15,9 \%)$ & $4,1(17,6)$ & $9,7(22,2)$ & $185(15,8 \%)$ & $6,0(14,8)$ \\
\hline 65-74 éves & $267(13,2 \%)$ & $70,3(17,1)$ & $0,772(0,216)$ & $16,8(24,7)$ & $19(1,6 \%)$ & $2,6(11,5)$ & $14,5(2,1,8)$ & $19(1,6 \%)$ & $13,7(19,2)$ \\
\hline 75-84 éves & $145(7,2 \%)$ & $60,3(16,9)$ & $0,661(0,235)$ & $30,3(28,9)$ & - & - & - & - & - \\
\hline 85 év felett & $41(2,0 \%)$ & $57,0(20,4)$ & $0,549(0,332)$ & $42,9(32,0)$ & - & - & - & - & - \\
\hline Iskolai végzettség & & $\mathrm{p}=0,000$ & $\mathrm{p}=0,000$ & $\mathrm{p}=0,000$ & & $\mathrm{p}=0,118$ & $\mathrm{p}=0,102$ & & $\mathrm{p}=0,436$ \\
\hline Alapfokú & $844(41,7 \%)$ & $75,8(19,8)$ & $0,828(0,235)$ & $14,8(25,8)$ & $400(33,5 \%)$ & $4,8(19,3)$ & $9,7(24,2)$ & $387(33,1 \%)$ & $5,2(16,1)$ \\
\hline Érettségi & $770(38,1 \%)$ & $85,6(14,4)$ & $0,908(0,176)$ & $5,9(16,4)$ & $511(42,8 \%)$ & $3,5(15,8)$ & $7,5(20,5)$ & $502(42,9 \%)$ & $4,5(14,4)$ \\
\hline Föiskola/egyetem & $409(20,2 \%)$ & $86,1(13,4)$ & $0,921(0,160)$ & $5,4(14,5)$ & $283(23,7 \%)$ & $2,2(12,5)$ & $5,0(15,9)$ & $280(24,0 \%)$ & $2,9(10,4)$ \\
\hline
\end{tabular}




\begin{tabular}{|c|c|c|c|c|c|c|c|c|c|}
\hline \multirow[t]{2}{*}{ Változók } & \multirow[t]{2}{*}{$\mathbf{N}(\%)$} & \multirow{2}{*}{$\begin{array}{c}\text { EQ VAS, } \\
\text { N=2023 } \\
\text { Átlag (SD) }\end{array}$} & \multirow{2}{*}{\begin{tabular}{|c|}
$\begin{array}{c}\text { EQ-5D-3L } \\
\text { index, } \mathrm{N}=2019\end{array}$ \\
Átlag (SD) \\
\end{tabular}} & \multirow{2}{*}{\begin{tabular}{|c|} 
WPAI, más \\
tevékenységekben \\
aktivitás \\
csökkenés, \% \\
N=2023 \\
Átlag (SD)
\end{tabular}} & \multicolumn{2}{|c|}{$\begin{array}{c}\text { WPAI, absenteeism, \% } \\
\text { N=1194 }\end{array}$} & \multirow{2}{*}{$\begin{array}{c}\begin{array}{c}\text { WPAI összesített } \\
\text { termelékenység- } \\
\text { veszteség \% N=1194 }\end{array} \\
\text { Átlag (SD) }\end{array}$} & \multicolumn{2}{|c|}{$\begin{array}{c}\text { WPAI presenteeism, \%, } \\
\text { N=1169 }\end{array}$} \\
\hline & & & & & $\mathrm{N}(\%)$ & Átlag (SD) & & $\mathbf{N}(\%)$ & Átlag (SD) \\
\hline $\begin{array}{ll}\text { Édesanyja } & \text { iskolai } \\
\text { végzettsége } & \\
\end{array}$ & & $\mathrm{p}=0,000$ & $\mathrm{p}=0,000$ & $\mathrm{p}=0,000$ & & $\mathrm{p}=0,015$ & $\mathrm{p}=0,009$ & & $\mathrm{p}=0,187$ \\
\hline Alapfokú & $1283(63,4 \%)$ & $78,0(18,9)$ & $0,840(0,227)$ & $12,8(24,0)$ & $659(55,2 \%)$ & $4,8(18,9)$ & $9,6(23,6)$ & $640(54,7 \%)$ & $5,2(15,6)$ \\
\hline Középfokú & $509(25,2 \%)$ & $87,3(12,5)$ & $0,938(0,142)$ & $3,9(12,5)$ & $365(30,6 \%)$ & $2,1(12,8)$ & $4,9(15,9)$ & $360(30,8 \%)$ & $2,9(9,9)$ \\
\hline Főiskola/egyetem & $231(11,4 \%)$ & $89,3(11,3)$ & $0,949(0,121)$ & $4,0(13,4)$ & $170(14,2 \%)$ & $2,1(11,8)$ & $5,9(18,6)$ & $169(14,5 \%)$ & $4,5(15,9)$ \\
\hline Lakóhely & & $\mathrm{p}=0,004$ & $\mathrm{p}=0,004$ & 0,271 & & $\mathrm{p}=0,268$ & $\mathrm{p}=0,158$ & & $\mathrm{p}=0,334$ \\
\hline Budapest & $399(19,7 \%)$ & $85,5(14,2)$ & $0,901(0,187)$ & $6,1(14,3)$ & $263(22,0 \%)$ & $2,3(13,4)$ & $4,8(15,0)$ & $259(22,2 \%)$ & $2,6(7,4)$ \\
\hline Más város & $1062(52,5 \%)$ & $80,8(17,8)$ & $0,871(0,199)$ & $10,1(21,9)$ & $613(51,3 \%)$ & $3,8(16,4)$ & $7,8(21,0)$ & $601(51,4 \%)$ & $4,2(14,0)$ \\
\hline Egyéb & $562(27,8 \%)$ & $80,4(18,4)$ & $0,871(0,224)$ & $10,9(23,2)$ & $318(26,7 \%)$ & $4,3(18,5)$ & $9,7(24,4)$ & $309(26,4 \%)$ & $6,0(18,1)$ \\
\hline Családi állapot & & $\mathrm{p}=0,000$ & $\mathrm{p}=0,000$ & $\mathrm{p}=0,000$ & & $\mathrm{p}=0,921$ & $\mathrm{p}=0,004$ & & $\mathrm{p}=0,000$ \\
\hline Házas & $939(46,4 \%)$ & $81,4(16,5)$ & $0,891(0,179)$ & $8,0(18,5)$ & $576(48,2 \%)$ & $3,2(14,5)$ & $6,4(18,0)$ & $568(48,6 \%)$ & $3,4(11,3)$ \\
\hline Élettársi kapcsolatban & $301(14,9 \%)$ & $88,6(13,1)$ & $0,940(0,141)$ & $3,9(14,2)$ & $241(20,2 \%)$ & $5,4(21,0)$ & $9,3(25,1)$ & $232(19,8 \%)$ & $4,4(16,3)$ \\
\hline Nőtlen / hajadon & $387(19,1 \%)$ & $88,3(14,4)$ & $0,933(0,174)$ & $4,6(15,9)$ & $259(21,7 \%)$ & $2,9(14,5)$ & $6,6(19,4)$ & $255(21,8 \%)$ & $3,9(13,6)$ \\
\hline Özvegy & $207(10,2 \%)$ & $65,4(18,7)$ & $0,658(0,277)$ & $2,9(30,5)$ & $17(1,4 \%)$ & $5,9(24,3)$ & $18,8(30,4)$ & $16(1,4 \%)$ & $13,8(22,8)$ \\
\hline Elvált & $185(9,1 \%$ & $75,5(18,1)$ & $0,835(0,208)$ & $15,1(25,7)$ & $100(8,4 \%)$ & $3,5(17,8)$ & $12,0(26,0)$ & $97(8,3 \%)$ & $9,2(21,0)$ \\
\hline Egyéb & $4(0,2 \%)$ & $73,8(23,6)$ & $0,802(0,233)$ & $12,5(25,0)$ & $1(0,1 \%)$ & 0,0 & 0,0 & $1(0,1 \%)$ & 0,0 \\
\hline $\begin{array}{l}\text { Házas/élettársi } \\
\text { kapcsolatban él }\end{array}$ & & $\mathrm{p}=0,000$ & $\mathrm{p}=0,000$ & $\mathrm{p}=0,000$ & & $\mathrm{p}=0,289$ & $\mathrm{p}=0,263$ & & $\mathrm{p}=0,044$ \\
\hline nem & $783(38,7 \%)$ & $79,1(19,2)$ & $0,837(0,242)$ & $13,5(25,1)$ & $377(31,6 \%)$ & $3,2(15,9)$ & $8,5(22,1)$ & $369(31,6 \%)$ & $5,7(16,5)$ \\
\hline igen & $1240(61,3 \%)$ & $83,2(16,0)$ & $0,903(0,172)$ & $7,0(17,6)$ & $817(68,4 \%)$ & $3,8(16,7)$ & $7,2(20,4)$ & $800(68,4 \%)$ & $3,7(13,0)$ \\
\hline
\end{tabular}

*Négy válaszadó nem válaszolta meg az EQ-5D-3L leíró részének mind az öt kérdését, ezért az ő esetükben nem lehetett EQ-5D-3L index értéket számolni.**Összesen 1232 válaszadó végzett fizetett munkát, 32 közülük azonban azt válaszolta, hogy 0 munkaórát hiányzott egészségügyi problémák miatt és 0 munkaórát dolgozott az elmúlt héten. További 27 esetben hiányzó válasz volt a 'Presenteeism’ kérdésre. Ezért a WPAI munkatermelékenység csökkenés eredményeihez 1173 válaszadó adatai kerültek feldolgozásra. 
6.1.3.4. A lakosság jól-léte

ICECAP-A éS ICECAP-O

A 65 év alattiak ( $\mathrm{n}=1568)$ esetében használt ICECAP-A kérdőívben a legmagasabb szintü képességeket a Kötődés, Kellemes élmények és az Autonómia dimenzióiban találtuk $(59,4 \%, 56,6 \%$, illetve 52,6\%). Az Eredmények és előrehaladás dimenzió nem volt problematikus a válaszadók 43,4\% -ánál, és a válaszadóknak csak körülbelül fele (51,8\%) érezte magát biztosnak az élet minden területén.

Az ICECAP-O kérdőív a 65 éves és afeletti korosztályra (mintánkban 453 kitöltőre) vonatkozott. A Kötődés dimenzióban válaszadók közel kétharmada $(64,9 \%)$ jelentett valamilyen szintü problémát. A Kellemes élmények dimenzióban ez az arány még magasabb volt: 78,4\% jelezte bármilyen probléma fennállását. A Függetlenség a többség számára problémát jelentett (71,1\%), és a Szerep-problémák (az a képesség, hogy értékes dolgokat csináljunk) általában jelen voltak $(72,8 \%)$, valamint a jövőbeli (biztonsági) problémák is $(75,7 \%)$. (8. és 9 . Ábra)

A nemek közötti különbségek mindkét ICECAP kérdőív estében kismértéküek voltak. Az ICECAP-A index átlaga 0,89 (SD=0,13) volt, még az ICECAP-O (65 év felettiek esetében) index átlaga $0,83(\mathrm{SD}=0,15)$. 


\section{8. Ábra ICECAP-A válaszok megoszlása nemek szerint (\%)}

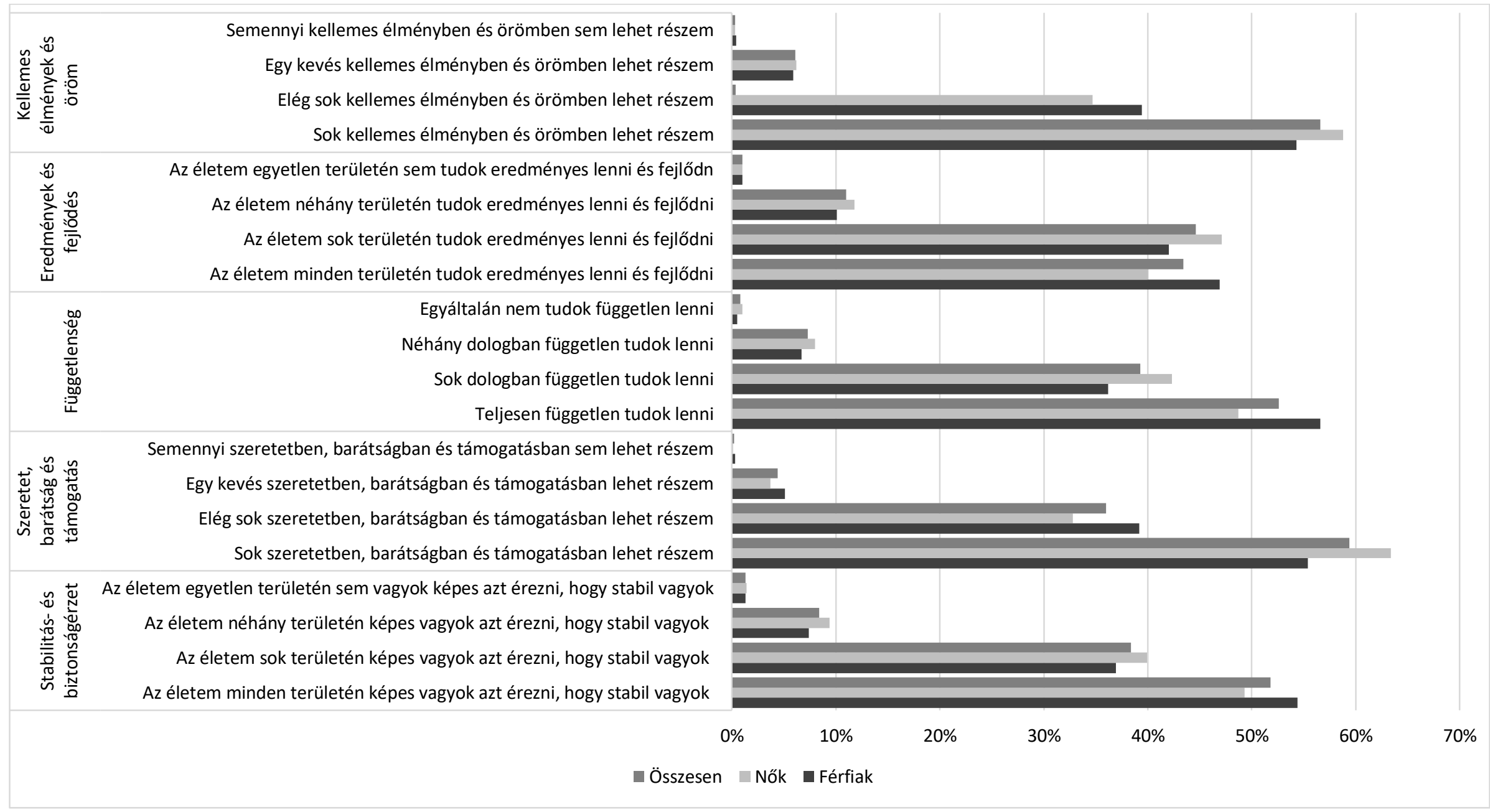




\section{9. Ábra ICECAP-O válaszok megoszlása nemek szerint (\%)}

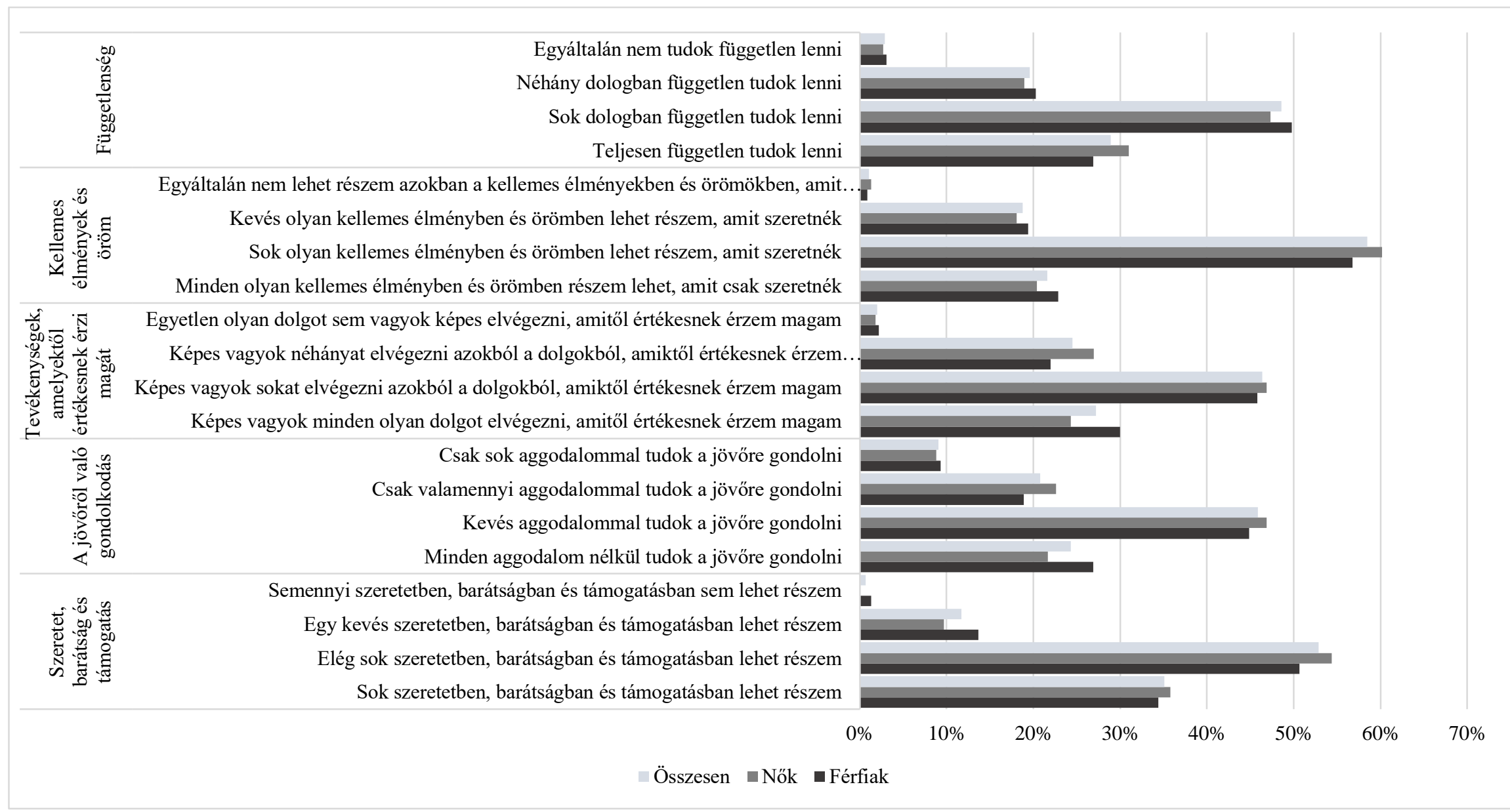




\subsubsection{Az eltérő mércék összefüggései}

A válaszadó egészségi állapotára, jól-létére és munkaképességére vonatkozó mércék közötti kapcsolat felderítése érdekében Spearman-féle rangkorrelációt számoltunk. Szignifikáns, negatív kapcsolatot találtunk az EQ-5D-5L index érték és a WPAI absenteeism $(\mathrm{r}=-0,116)$, presenteeism $(\mathrm{r}=-0,399)$, összesített termelékenységveszteség munkavégzés közben $(\mathrm{r}=-0,371)$, valamint a más tevékenységekben tapasztalt aktivitás csökkenéssel ( $\mathrm{r}=-0,593)$ ( $\mathrm{p}<0,001$ minden esetben). Az EQ-5D-3L értékek nagyon hasonló eredményeket mutattak: rendre $r=-0,116, r=-0,387, r=0,359$ és $r=-0,592(p<0,001$ minden esetben). A háztartás nettó havi jövedelme a WPAI értékek közül csak a más tevékenységekben tapasztalt aktivitás csökkenéssel mutatott szignifikáns kapcsolatot ( $\mathrm{r}=-$ 0,277, p=0,000). Az ICECAP-A és ICECAP-O értékek szignifikáns negatív kapcsolatot mutattak a WPAI értékkel. A válaszadók életkora pozitív szignifikáns kapcsolatot mutatott a presenteeism ( $\mathrm{r}=0,141)$, az összesített termelékenységveszteség munkavégzés közben $(r=0,113)$ és a más tevékenységekben tapasztalt aktivitás csökkenéssel $(r=0,412)$ ( $p<0,001$ minden esetben). (7. Táblázat) 
7. Táblázat Az egyes mércék és válaszadók jellemzőinek összefüggései (korrelációs együtthatók)

\begin{tabular}{|c|c|c|c|c|c|c|c|c|c|c|c|}
\hline & & $\begin{array}{l}\text { Abstenteeis } \\
\text { m }(\%)\end{array}$ & $\begin{array}{l}\text { Presenteeis } \\
\text { m }(\%)\end{array}$ & $\begin{array}{c}\text { Összesített } \\
\text { termelékenység- } \\
\text { veszteség } \\
\text { munkavégzés } \\
\text { közben (\%) } \\
\end{array}$ & $\begin{array}{c}\text { Más } \\
\text { tevékenységekben } \\
\text { aktivitás } \\
\text { csökkenés }(\%)\end{array}$ & $\begin{array}{l}\text { EQ-5D-5L } \\
\text { index érték }\end{array}$ & $\begin{array}{l}\text { EQ-5D-3L } \\
\text { index érték }\end{array}$ & Életkor & \begin{tabular}{c|}
\multicolumn{1}{c|}{ A } \\
háztartás \\
nettó havi \\
jövedelme
\end{tabular} & ICECAP-A & ICECAP-O \\
\hline \multirow{2}{*}{ Abstenteeism (\%) } & $\mathrm{r}$ & 1 & & & & & & & & & \\
\hline & $\mathrm{p}$ & 0,000 & & & & & & & & & \\
\hline \multirow{2}{*}{ Presenteeism (\%) } & $\mathrm{r}$ & $0,147 * *$ & 1 & & & & & & & & \\
\hline & $\mathrm{p}$ & 0,000 & 0,000 & & & & & & & & \\
\hline \multirow{2}{*}{$\begin{array}{l}\text { Összesített } \\
\text { termelékenységveszteség } \\
\text { munkavégzés közben }(\%)\end{array}$} & $\mathrm{r}$ & $0,585^{* *}$ & $0,900 * *$ & 1 & & & & & & & \\
\hline & $\mathrm{p}$ & 0,000 & 0,000 & 0,000 & & & & & & & \\
\hline \multirow{2}{*}{$\begin{array}{l}\text { Más tevékenységekben } \\
\text { aktivitás csökkenés (\%) }\end{array}$} & $\mathrm{r}$ & $0,134 * *$ & $0,768 * *$ & $0,660 * *$ & 1 & & & & & & \\
\hline & $\mathrm{p}$ & 0,000 & 0,000 & 0,000 & 0,000 & & & & & & \\
\hline \multirow{2}{*}{ EQ-5D-5L index érték } & $\mathrm{r}$ & $-0,116^{* *}$ & $-0,399 * *$ & $-0,371 * *$ & $-0,593 * *$ & 1 & & & & & \\
\hline & $\mathrm{p}$ & 0,000 & 0,000 & 0,000 & 0,000 & 0,000 & & & & & \\
\hline \multirow{2}{*}{ EQ-5D-3L index érték } & $\mathrm{r}$ & $-0,116^{* *}$ & $-0,387 * *$ & $-0,359 * *$ & $-0,592 * *$ & $0,918 * *$ & 1 & & & & \\
\hline & $\mathrm{p}$ & 0,000 & 0,000 & 0,000 & 0,000 & 0,000 & 0,000 & & & & \\
\hline \multirow{2}{*}{ Életkor } & $\mathrm{r}$ & 0,008 & $0,141^{* *}$ & $0,113^{* *}$ & $0,412 * *$ & $-0,500 * *$ & $-0,490 * *$ & 1 & & & \\
\hline & $\mathrm{p}$ & 0,782 & 0,000 & 0,000 & 0,000 & 0,000 & 0,000 & 0,000 & & & \\
\hline \multirow{2}{*}{$\begin{array}{l}\text { A háztartás nettó havi } \\
\text { jövedelme }\end{array}$} & $\mathrm{r}$ & $-0,024$ & $-0,029$ & $-0,035$ & $-0,277 * *$ & $0,381 * *$ & $0,383 * *$ & $-0,371 * *$ & 1 & & \\
\hline & $\mathrm{p}$ & 0,496 & 0,415 & 0,33 & 0,000 & 0,000 & 0,000 & 0,000 & 0,000 & & \\
\hline \multirow{2}{*}{ ICECAP-A } & $\mathrm{r}$ & $-0,070^{*}$ & $-0,212 * *$ & $-0,196 * *$ & $-0,281 * *$ & $0,469 * *$ & $0,462 * *$ & $-0,210 * *$ & $0,221 * *$ & 1 & \\
\hline & $\mathrm{p}$ & 0,016 & 0,000 & 0,000 & 0,000 & 0,000 & 0,000 & 0,000 & 0,000 & 0,000 & \\
\hline \multirow{2}{*}{ ICECAP-O } & $\mathrm{r}$ & $-0,515^{*}$ & $-0,578^{* *}$ & $-0,585^{* *}$ & $-0,490 * *$ & $0,613^{* *}$ & $0,589 * *$ & $-0,179 * *$ & $0,236^{* *}$ & - & 1 \\
\hline & $\mathrm{p}$ & 0,017 & 0,006 & 0,005 & 0,000 & 0,000 & 0,000 & 0,000 & 0,000 & - & 0,000 \\
\hline
\end{tabular}

*0,05 szinten szignifikáns

$* * 0,01$ szinten szignifikáns 


\subsubsection{Informális ellátás és meghatározó tényezői krónikus betegségekben: magyarországi kutatások összehasonlító elemzése}

\subsubsection{Betegek}

Összesen 14 különböző vizsgálat felelt meg a beválogatási kritériumainknak, melyek mind különböző diagnózisokban történtek. A vizsgálatok a betegségek széles spektrumát fedték le: artritisz pszoriatika (AP) (Brodszky et al., 2009), időskori makuladegeneráció (age-related macular degeneration - AMD) (Péntek et al., 2012a), demencia (Érsek et al., 2010), endometriózis (Simoens et al., 2012), epilepszia (Pentek et al., 2013), húgyhólyagrák (Hever et al., 2015), jóindulatú prosztata megnagyobbodás (BPH) (Rencz et al., 2015c), oszteoporózis (Péntek et al., 2016b), Parkinson kór (Tamás et al., 2014), pszoriázis (Rencz et al., 2014, Balogh et al., 2014), reumatoid artritisz (RA) (Péntek et al., 2007), szisztémás szklerózis (SSc) (Minier et al., 2010), szklerózis multiplex (SM) (Péntek et al., 2012b), skizofrénia (Gulácsi et al., 2012).

A mintában összesen 2047 beteg szerepelt, a betegek átlagos életkora 58,9 (SD=16,3) év volt. A betegek 58,0\%-a volt nő, átlagos életkoruk 57,8 (SD 16,7) év volt, a férfiaké 60,3 $(\mathrm{SD}=15,6)$ év. A három legnagyobb betegszámmal rendelkező diagnózis az oszteoporózis $(\mathrm{n}=282)$, az RA $(\mathrm{n}=255)$ és a jóindulatú prosztata megnagyobbodás $(\mathrm{n}=246)$ volt. (8. Táblázat) 


\section{Táblázat A betegek jellemzői az egyes diagnózisokban}

\begin{tabular}{|c|c|c|c|c|c|c|c|c|}
\hline Betegségtípus (hivatkozás) & $\begin{array}{l}\text { Betegszám } \\
\text { (n) }\end{array}$ & $\begin{array}{c}\text { Nők aránya } \\
\text { (\%) }\end{array}$ & $\begin{array}{l}\text { Életkor, év } \\
\text { átlag (SD) }\end{array}$ & $\begin{array}{c}\text { Felsőfokú } \\
\text { végzettségúek } \\
\text { aránya }(\%)\end{array}$ & $\begin{array}{c}\text { Egyedül élők } \\
\text { aránya (\%) }\end{array}$ & $\begin{array}{c}\text { Betegség fennállási } \\
\text { idó, év } \\
\text { átlag (SD) }\end{array}$ & $\begin{array}{l}\text { EQ-5D-3L index, } \\
\text { átlag (SD) }\end{array}$ & $\begin{array}{c}\text { EQ VAS, } \\
\text { átlag (SD) }\end{array}$ \\
\hline Összesen & 2047 & $58,04 \%$ & $58,88(16,34)$ & $23,98 \%$ & $31,34 \%$ & $8,94(9,17)$ & $0,64(0,33)$ & $60,48(20,25)$ \\
\hline Oszteoporózis (Péntek et al., 2016b) & 282 & $100,00 \%$ & $69,58(8,58)$ & $23,32 \%$ & $67,38 \%$ & $7,28(5,34)$ & $0,58(0,32)$ & $58,96(17,06)$ \\
\hline Reumatoid artritisz (Péntek et al., 2007) & 255 & $85,83 \%$ & $55,45(12,31)$ & $16,80 \%$ & $22,00 \%$ & $9,10(9,27)$ & $0,46(0,33)$ & $51,65(19,81)$ \\
\hline Jóindulatú prosztata megnagyobbodás (Rencz et al., 2015c) & 246 & $0 \%$ & $70,59(8,13)$ & $25,62 \%$ & $12,30 \%$ & $5,56(4,86)$ & $0,85(0,19)$ & $68,37(15,54)$ \\
\hline Pszoriázis (Balogh et al., 2014) & 200 & $32,00 \%$ & $50,66(12,93)$ & $20,00 \%$ & $34,50 \%$ & $21,44(11,69)$ & $0,69(0,31)$ & $64,43(21,34)$ \\
\hline Arthritisz pszoriatika (Brodszky et al., 2009) & 183 & $57,38 \%$ & $50,15(12,92)$ & $23,63 \%$ & $20,22 \%$ & $9,24(9,24)$ & $0,47(0,35)$ & $54,68(20,01)$ \\
\hline Húgyhólyagrák (Hever et al., 2015) & 151 & $35,10 \%$ & $66,25(9,58)$ & $18,79 \%$ & NA & $3,57(3,74)$ & $0,79(0,24)$ & $67,80(19,34)$ \\
\hline Időskori makuladegeneráció (Péntek et al., 2012a) & 122 & $62,30 \%$ & $75,16(7,88)$ & $25,62 \%$ & $35,54 \%$ & $2,94(2,54)$ & $0,66(0,33)$ & $58,59(16,43)$ \\
\hline Parkinson kór (Tamás et al., 2014) & 110 & $34,29 \%$ & $63,28(11,26)$ & $36,36 \%$ & $21,70 \%$ & $8,22(5,78)$ & $0,59(0,28)$ & $59,32(17,92)$ \\
\hline Epilepszia (Pentek et al., 2013) & 100 & $58,00 \%$ & $36,65(12,49)$ & $18,00 \%$ & $47,00 \%$ & $15,45(12,12)$ & $0,80(0,29)$ & $73,84(15,85)$ \\
\hline Demencia (Érsek et al., 2010) & 88 & $59,77 \%$ & $77,55(8,52)$ & $13,64 \%$ & $18,60 \%$ & NA & $0,39(0,33)$ & $48,59(23,87)$ \\
\hline Endometriózis (Simoens et al., 2012) & 84 & $100 \%$ & $32,80(4,73)$ & $55,95 \%$ & $14,29 \%$ & $8,00(6,46)$ & $0,90(0,12)$ & NA \\
\hline Szisztémás szklerózis (Minier et al., 2010) & 80 & $90,00 \%$ & $57,39(9,60)$ & $20,00 \%$ & $27,50 \%$ & $7,16(6,63)$ & $0,58(0,29)$ & $56,25(18,73)$ \\
\hline Skizofrénia (Gulácsi et al., 2012) & 78 & $46,15 \%$ & $44,24(13,05)$ & $11,54 \%$ & NA & NA & $0,64(0,29)$ & $60,01(24,71)$ \\
\hline Szklerózis multiplex (Péntek et al., 2012b) & 68 & $70,59 \%$ & $37,96(9,08)$ & $41,79 \%$ & NA & $7,02(5,90)$ & $0,67(0,28)$ & $64,47(22,18)$ \\
\hline
\end{tabular}

NA: nincs adat 
Az oszteoporózisos betegek 59,9\%-nak volt már törése, combnyaktörés 4,3\%-nál fordult elő a kórelőzményben (Péntek et al., 2016b). Jóindulatú prosztata megnagyobbodásban a klinikai tünetek súlyosságát mutató International Prostate Symptom Score átlagos értéke 12,8 $(\mathrm{SD}=6,3)$ volt (Rencz et al., 2015c). A biológiai terápiában részesülők aránya a felméréskor időskori makuladegenerációban 83,6\%, pszoriázisban 51,5\%, AP-ban 6,0\%, RA-ban 0\% volt (Péntek et al., 2012a, Brodszky et al., 2009, Péntek et al., 2007, Balogh et al., 2014). Húgyhólyagrák csoportban a betegek 13,2\%-nál történt cisztektómia és 2,0\% csak palliatív kezelésben részesült (Hever et al., 2015). A Parkinson kóros betegcsoport 45,5\%-a tartozott a betegség súlyosságát mérö Hoehn\&Yahr skála I-II kategóriákba (Tamás et al., 2014). Az epilepszia betegcsoport 60,8\%-ának volt rohama a felmérést megelőző 12 hónap során (Pentek et al., 2013).A demenciával élő betegek átlagos Mini Mentál Teszt értéke 16,70 (SD=7,24) volt (Érsek et al., 2010). Szisztémás szklerózisban a diffúz kután alcsoport aránya 25,0\% volt (Minier et al., 2010). Endometriózisban a betegek 26,2\%-át kezelték mütéti úton (Simoens et al., 2012). Skizofréniában a betegek 39,7\%-a tartozott a közepesnél súlyosabb kategóriába a Globális Klinikai Skálán mérve (Gulácsi et al., 2012). Szklerózis multiplexben a betegség súlyosságát mérő Expanded Disability Status Scale átlagos értéke 1,9 (SD 1,7) volt (Péntek et al., 2012b).

6.1.4.2. Informális ellátás igénybevétele és tartama

A betegek 27,4\%-a jelezte, hogy igénybe vett informális ellátást, az aránya 6,5\% (jóindulatú prosztata megnagyobbodás) és $87,2 \%$ (demencia) közötti volt a különböző betegségekben. A betegek több mint egyharmada kapott informális ellátást demencia $(87,2 \%)$, reumatoid artritisz $(49,8 \%)$, szisztémás szklerózis $(38,8 \%)$, arthritisz pszoriatika $(37,7 \%)$ és szklerózis multiplex $(36,8 \%)$ betegcsoportok esetében. (10. Ábra) 


\section{0. Ábra Az informális ellátást igénybe vevők aránya betegségtípusonként (\%) és a betegcsoportok életkora}

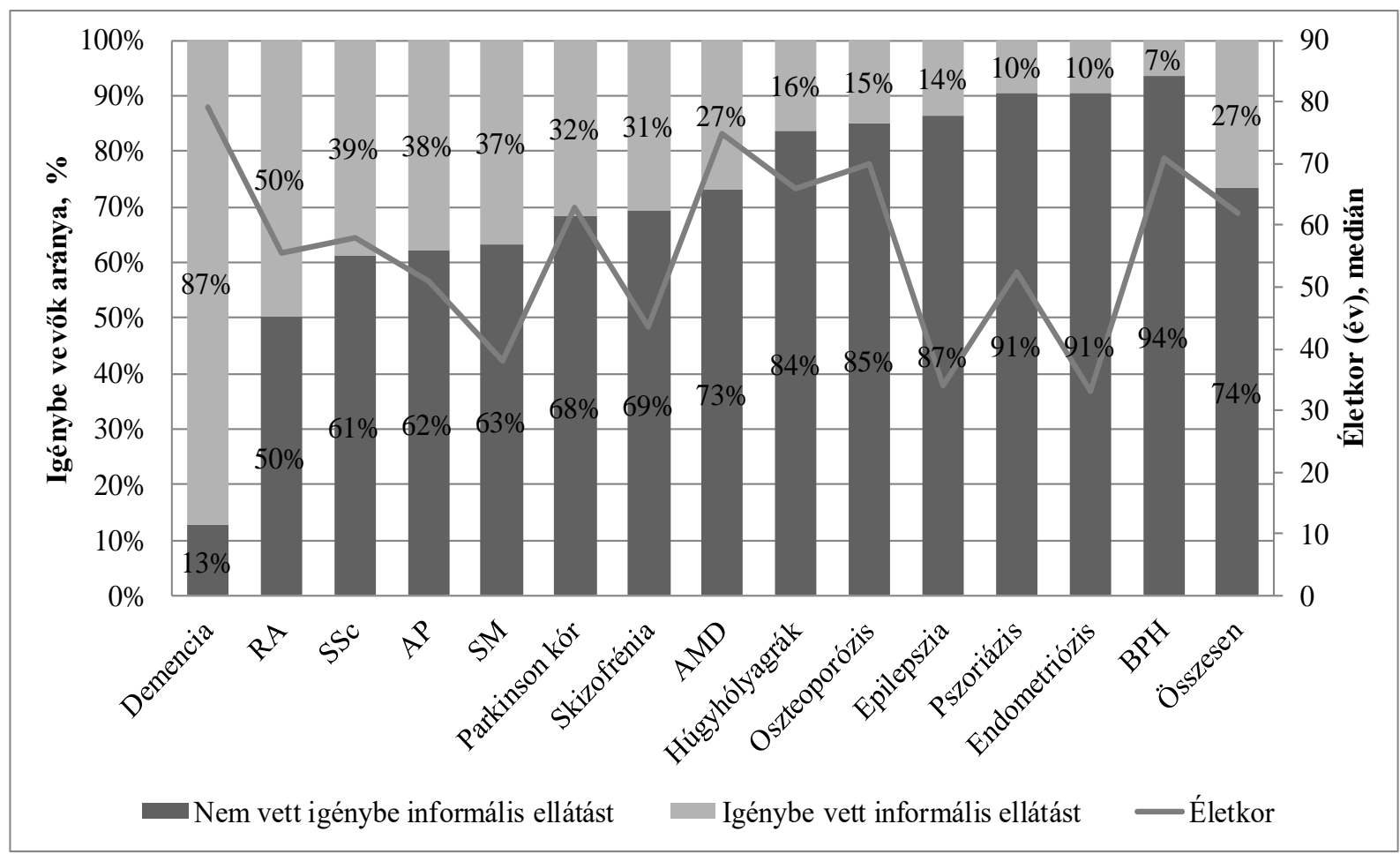

RA: reumatoid artritisz, SSc: szisztémás szklerózis, AP: arthritisz pszoriatika, SM: szklerózis multiplex, AMD: időskori makuladegeneráció, BPH: jóindulatú prosztata megnagyobbodás

Az informális ellátás heti átlagos óraszámát betegségenként a 11. Ábrán mutatjuk be. Alapesetben (24 óra/nap limitet alkalmazva) a teljes minta átlagos heti óraszáma 7,54 $(\mathrm{SD}=26,36)$ óra volt. Mindössze három betegségben haladta meg az informális ellátás időtartamának átlaga a heti 10 órát, jellemzően nagy szórással (óra/hét): demencia (72,19, $\mathrm{SD}=69,56), \mathrm{SM}(18,79, \mathrm{SD}=35,47)$ valamint Parkinson kór $(12,57, \mathrm{SD}=31,45)$. A legalacsonyabb heti informális ellátás idő endometriózisban, pszoriázisban, illetve jóindulatú prosztata megnagyobbodásban volt megfigyelhető, mindhárom esetben heti 2 óra alatti átlaggal (rendre: $1,20, \mathrm{SD}=5,05 ; 1,36, \mathrm{SD}=12,11$; illetve 1,51, $\mathrm{SD}=7,18$ óra/hét). A Kruskal-Wallis teszt eredményei alapján a csoportok közötti eltérések szignifikánsak $(\mathrm{p}=0,000)$.

Másodlagos elemzésünkben (napi 8 órás limit alkalmazásával) az informális ellátás átlagosan heti 4,83 óra ( $\mathrm{SD}=12,2$ óra) volt, az elsődleges elemzéshez képest az átlagos óraszám demencia és epilepszia betegségben csökkent legnagyobb mértékben. (11. Ábra) Mindkét megközelítés esetén 5 óra/hét feletti átlag volt demencia, SM, Parkinson kór, 
RA, SSc és AP betegségekben. Kruskal-Wallis teszt eredményei alapján a csoportok közötti eltérések szintén szignifikánsak $(\mathrm{p}=0,000)$.

11. Ábra Igénybe vett informális ellátás átlagos ideje diagnózisonként (óra/hét), betegeként napi 24 illetve 8 óra limit alkalmazásával

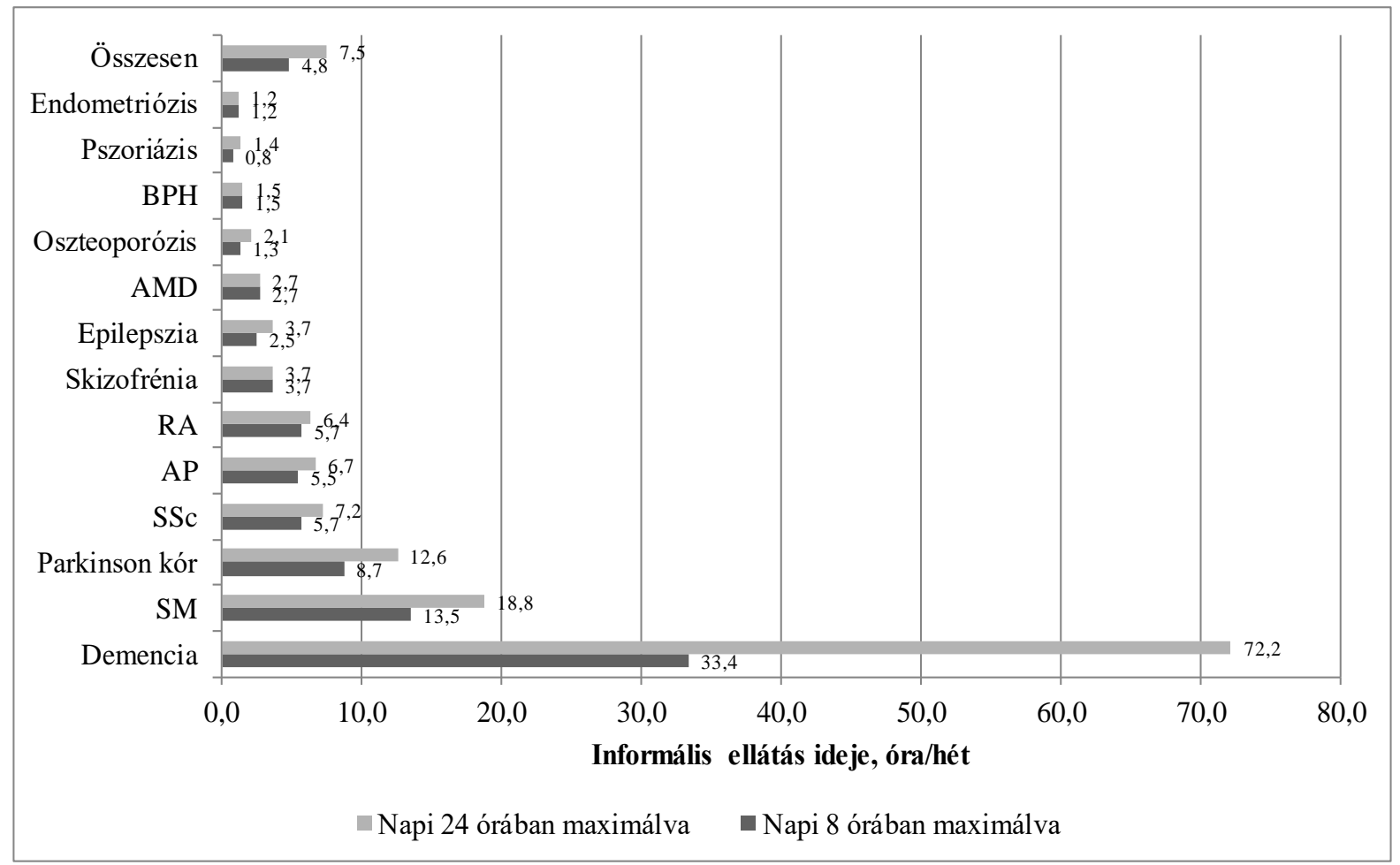

RA: reumatoid artritisz, SSc: szisztémás szklerózis, AP: arthritisz pszoriatika, SM: szklerózis multiplex, AMD: időskori makuladegeneráció, BPH: jóindulatú prosztata megnagyobbodás

\subsubsection{A betegek egészségi állapota az EQ-5D-3L alapján}

A teljes mintát tekintve a legtöbb beteg a Fájdalom/rossz közérzet, Mozgékonyság és a Szorongás/lehangoltság dimenziókban jelezte, hogy némi vagy súlyos problémát jelent számára (rendre 62,8\%, 52,9\%,51,7\%), ebből a súlyos problémát jelzők aránya rendre 10,7\%, 0,7\% illetve 7,3\% volt. Az Önellátás és a Szokásos tevékenységek dimenziókban a betegek 74,8\% illetve 53,3\%-a jelölte azt, hogy nincs problémája. A Mozgékonyság dimenzióban az RA, Parkinson kór és AP betegcsoportokban volt a legmagasabb a problémát jelzők aránya (rendre $82,2 \%, 81,9 \%, 79,9 \%$ ) és ugyancsak az Önellátás 
dimenzióban (rendre 52,3\%, 55,3\%, 48,9\%). A Szokásos tevékenységek dimenzióban legtöbben az SSc, AP és RA betegségekben jeleztek problémát (rendre 77,9\%, 77,5\%, $75,8 \%$ ). Fájdalom/rossz közérzet az RA, AP és osteoporosis betegcsoportokban fordult elő legmagasabb arányban (rendre 91,9\%, 90,6\%, 87,7\%), míg Szorongás/lehangoltság skizofrénia, SSc és Parkinson kór diagnózisokban (rendre 76,9\%, 70,0\%, 68,3\%).

6.1.4.4. Informális ellátást igénybe vevők és nem vevők összehasonlítása

Az informális ellátást igénybe vevők átlagosan 3,7 évvel voltak idősebbek, mint az informális ellátásban nem részesülök. A férfi betegek megközelítőleg egyötöde (19,9\%) vett igénybe informális ellátást, még a nők csaknem egyharmada (32,5\%). A nem egyedül élők valamivel kisebb része vett igénybe informális ellátást a betegek önbevallása alapján, mint az egyedül élök (70,9\% versus 75,6\%). Iskolázottsági szint szerint az alapfokú vagy alacsonyabb végzettséggel rendelkezők körében volt a legmagasabb, míg a felsőfokú végzettségüek esetében a legalacsonyabb az informális ellátást igénybe vevők aránya (rendre $41,9 \%$ és $22,8 \%$ ). (9. Táblázat) 
9. Táblázat Informális ellátás igénybevétel alapján képzett csoportok demográfiai és egészségi állapotának jellemzői

\begin{tabular}{|c|c|c|}
\hline Változók & $\begin{array}{l}\text { Nem vett igénybe } \\
\text { informális ellátást } \\
\text { átlag (SD) / n (\%) }\end{array}$ & $\begin{array}{c}\text { Igénybe vett } \\
\text { informális ellátást } \\
\text { átlag }(\mathrm{SD}) / \mathbf{n}(\%)\end{array}$ \\
\hline Betegszám & 1480 & 558 \\
\hline Életkor & $57,88(16,46)$ & $61,58(15,60)$ \\
\hline \multicolumn{3}{|l|}{ Nem } \\
\hline Nő & $797(53,9 \%)$ & $384(69,4 \%)$ \\
\hline Férfi & $682(46,1 \%)$ & $169(30,6 \%)$ \\
\hline \multicolumn{3}{|l|}{ Lakhatás } \\
\hline Egyedül él & $411(32,8 \%)$ & $133(27,8 \%)$ \\
\hline Hozzátartozóval él & $841(67,2 \%)$ & $346(72,2 \%)$ \\
\hline Betegség fennállási idő, év & $8,76(9,15)$ & $9,52(9,23)$ \\
\hline \multicolumn{3}{|l|}{ Iskolázottság } \\
\hline Általános iskolánál & $5(0,4 \%)$ & $4(0,7 \%)$ \\
\hline Általános iskola & $275(23,2 \%)$ & $198(36,7 \%)$ \\
\hline Szakiskola & $35(3,0 \%)$ & $12(2,2 \%)$ \\
\hline Középfokú & $557(47,0 \%)$ & $233(43,2 \%)$ \\
\hline Felsőfokú & $312(26,4 \%)$ & $92(17,1 \%)$ \\
\hline EQ-5D-3L index $(-0,594-1)$ & $0,73(0,27)$ & $0,42(0,35)$ \\
\hline EQ VAS $(0-100)$ & $65,03(18,71)$ & $49,29(19,56)$ \\
\hline
\end{tabular}

Az átlagos betegségtartam az informális ellátást igénybe vevők esetében 0,76 évvel volt hosszabb, mint az informális ellátásban nem részesülőké, az eltérés nem szignifikáns $(\mathrm{p}=0,066)$. Az EQ-5D-3L mind az öt dimenziójában magasabb volt a némi vagy súlyos problémát jelzők aránya az informális ellátásban részesülők között, mint akik nem kaptak ilyen gondozást. (12. Ábra) A legnagyobb különbség a Szokásos tevékenységek és az Önellátás dimenzióban volt (48,2\% illetve 44,8\%). A két csoport EQ-5D-3L index és EQ VAS által mért egészségi állapotának összehasonlítására Mann-Whitney U próbát használtunk, az informális ellátást igénybe vevők egészségi állapota mindkét mércével szignifikánsan rosszabb volt, mint az informális ellátásban nem részesülőké ( $p=0,000$ és $\mathrm{p}=0,000)$. Az informális ellátásban részesülő alcsoport átlagos informális gondozási idejét a 13. Ábrán mutatjuk be. (13. Ábra) 
12. Ábra Problémát jelzők aránya (\%) az egyes EQ-5D-3L dimenziókban az informális ellátásban részesülő és nem részesülő alcsoportokban

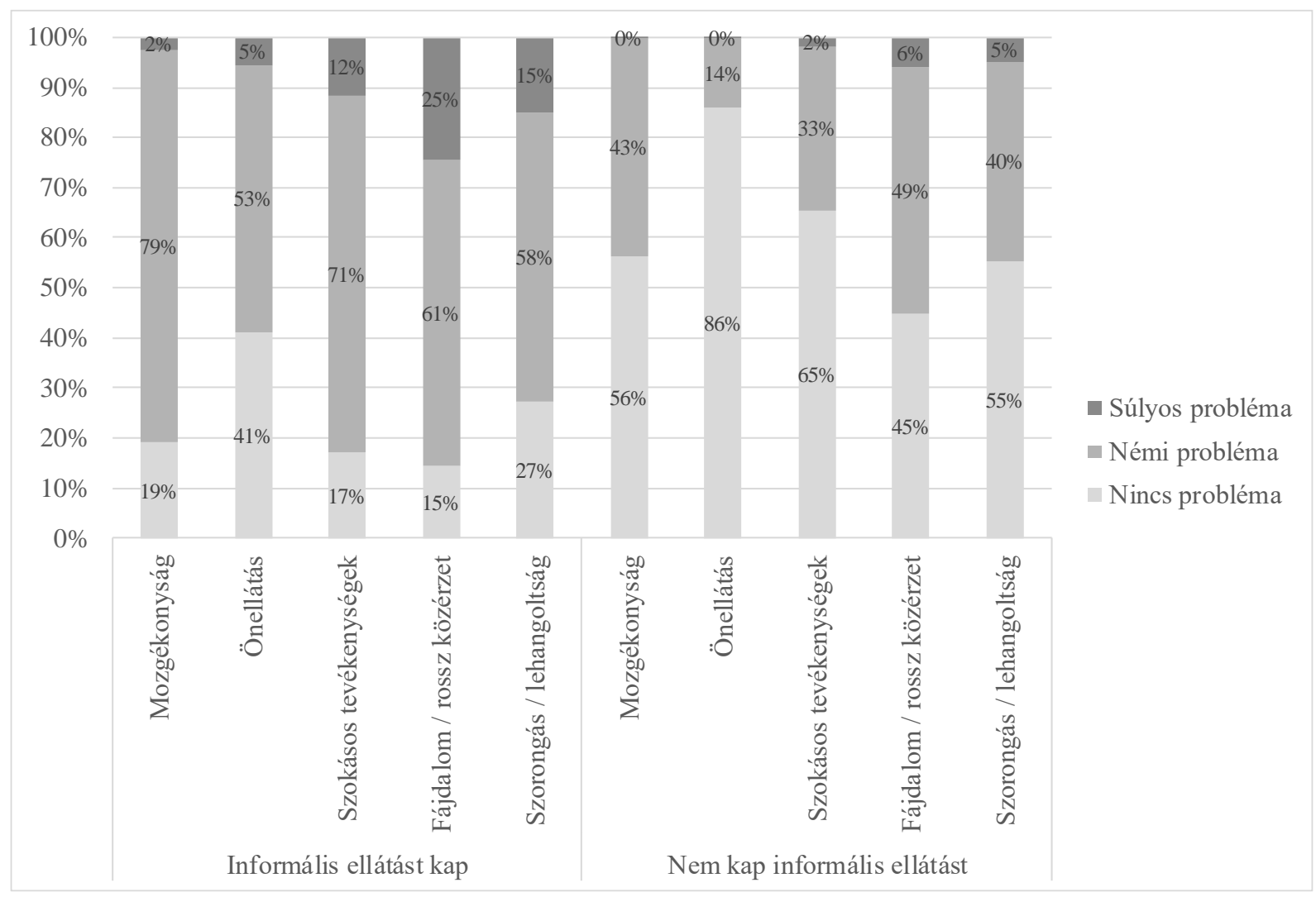




\section{3. Ábra Az informális ellátást igénybe vevő alcsoportban az informális ellátás}

átlagos ideje (óra/hét), betegenként napi 8 illetve 24 óra limit alkalmazásával

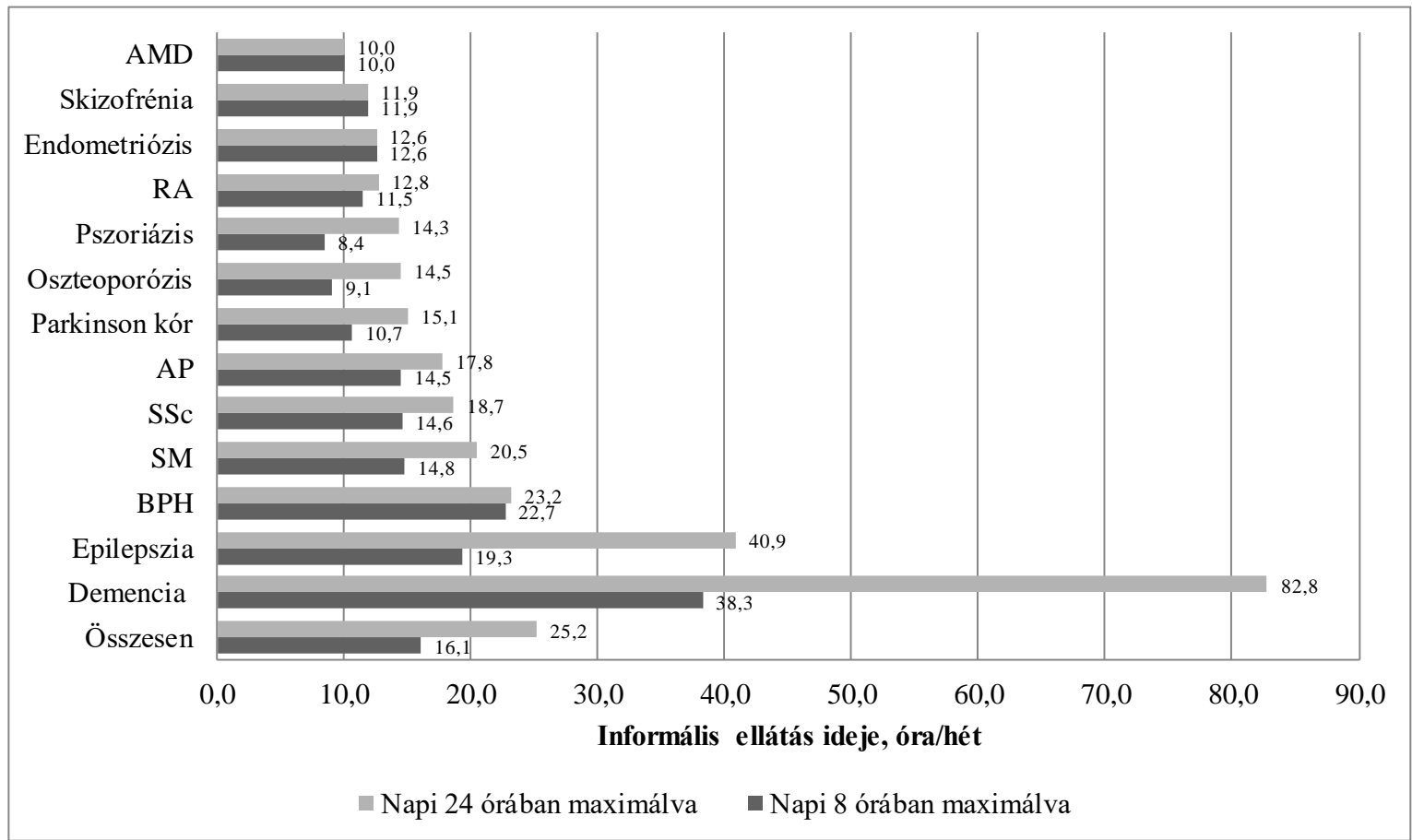

RA: reumatoid artritisz, SSc: szisztémás szklerózis, AP: arthritisz pszoriatika, SM: szklerózis multiplex, AMD: időskori makuladegeneráció, BPH: jóindulatú prosztata megnagyobbodás

Az informális ellátás igénybevételének ideje és a betegek életminősége közötti kapcsolat vizsgálatára Spearman-féle korrelációt számoltunk. Az EQ-5D-3L index és az EQ VAS esetében is negatív irányú, szignifikáns, azonban közepesnél gyengébb kapcsolat volt megfigyelhető az informális ellátás heti óraszámával. ( $\mathrm{r}=-0,415, \mathrm{p}=0,000$, valamint $\mathrm{r}=-$ $0,328, \mathrm{p}=0,000)$

\subsubsection{Az informális ellátást meghatározó tényezők: regressziós modell}

Az egy hét során igénybe vett informális ellátás idejét magyarázó tényezők felderítésére lineáris regressziós modellt építettünk. A modellben a betegek egészségi állapotát, demográfiai jellemzőit és a diagnózist kifejező dummy változókat szerepeltettük magyarázó változóként (modellünkben a viszonyítási alapot az RA-t kifejező változó adta). Az EQ-5D-3L index ( $p=0,002)$, az EQ VAS ( $p=0,000)$, a beteg neme $(p=0,044)$, valamint az oszteoporózis $(\mathrm{p}=0,011)$ és a Parkison kór $(\mathrm{p}=0,011)$ fennállását jelző 
változók voltak szignifikánsak. (10. Táblázat) A modellben az $\mathrm{R}$ négyzet értéke 0,062 volt.

Amennyiben a napi 8 órában maximált informális ellátás idejét (óra/hét) tekintettük eredményváltozónak, a magyarázó változók közül az életkor $(\mathrm{p}=0,017)$, a beteg neme $(\mathrm{p}=0,016)$, az EQ VAS $(\mathrm{p}=0,000)$, az EQ-5D-3L index $(\mathrm{p}=0,000)$ és egyes betegségek fennállását kifejező dummy változók voltak szignifikánsak (Parkinson betegség $\mathrm{p}=0,009$; oszteoporózis $\mathrm{p}=0,000$; időskori makuladegeneráció $\mathrm{p}=0,021$; pszoriázis $\mathrm{p}=0,029$ ). Modellünkben az $\mathrm{R}$ négyzet értéke ez esetben 0,111 volt, vagyis csak korlátozottan tudunk következtetni az általunk használt magyarázó változók alapján a heti szinten igénybe vett informális ellátás értékére.

10. Táblázat Lineáris regressziós modell az igénybe vett informális ellátás idejére (óra/hét) vonatkozóan

\begin{tabular}{|l|r|r|r|r|r|}
\hline \multirow{2}{*}{ Változók } & \multicolumn{2}{|c|}{$\begin{array}{c}\text { Nem } \\
\text { standardizált } \\
\text { koefficiensek }\end{array}$} & $\begin{array}{c}\text { Standardizált } \\
\text { koefficiensek }\end{array}$ & \multirow{2}{*}{ t } & Szignifikancia \\
\cline { 2 - 5 } & B & $\begin{array}{c}\text { Std. } \\
\text { hiba }\end{array}$ & \multicolumn{2}{c|}{ Beta } & \\
\hline Konstans & 7,909 & 3,088 & - & 2,562 & 0,011 \\
\hline Életkor & 0,060 & 0,041 & 0,057 & 1,477 & 0,140 \\
\hline Betegség fennállás & 0,027 & 0,054 & 0,016 & 0,505 & 0,613 \\
\hline Nem & 2,371 & 1,174 & 0,072 & 2,020 & 0,044 \\
\hline EQ VAS & $-0,091$ & 0,025 & $-0,110$ & $-3,615$ & 0,000 \\
\hline EQ-5D & $-4,840$ & 1,543 & $-0,098$ & $-3,138$ & 0,002 \\
\hline Arthritisz pszoriatika & 1,434 & 1,655 & 0,029 & 0,866 & 0,386 \\
\hline Pszoriázis & $-1,641$ & 1,892 & $-0,034$ & $-0,867$ & 0,386 \\
\hline Idöskori & $-2,723$ & 2,067 & $-0,047$ & $-1,318$ & 0,188 \\
\hline Szisztémás szklerózis & 1,468 & 2,065 & 0,021 & 0,711 & 0,477 \\
\hline Oszteoporózis & $-4,293$ & 1,691 & $-0,091$ & $-2,538$ & 0,011 \\
\hline $\begin{array}{l}\text { Jóindulatún prosztata } \\
\text { megnagyobbodás }\end{array}$ & $-0,281$ & 2,031 & $-0,006$ & $-0,138$ & 0,890 \\
\hline Epilepszia & 4,160 & 2,197 & 0,065 & 1,893 & 0,059 \\
\hline Parkinson kór & 5,514 & 2,155 & 0,081 & 2,558 & 0,011 \\
\hline
\end{tabular}

Kódolás: férfi $=0$, nő $=1$; diagnózisok: $0=$ nem, $1=$ igen 


\subsection{Költségszámítás}

\subsubsection{Az informális ellátás költsége krónikus betegségekben: magyarországi kutatások összehasonlító elemzése}

Az elemzésünkbe bevont 13 kutatásba összesen 1896 beteg került beválogatása, átlagos életkoruk 58,29 ( $\mathrm{SD}=16,62)$ év volt, közülük 59,9\% volt nö, az ő átlagos életkoruk 57,45 (SD 16,98) év volt, a férfiaké pedig 59,51 (SD=16,01) év. A vizsgálatok a jelentős, nagy prevalenciájú betegségekre és a ritkábban előforduló megbetegedésekre egyaránt kiterjedtek, a három legnagyobb betegszámmal rendelkező betegség az oszteoporózis $(\mathrm{n}=282)$, az RA $(\mathrm{N}=255)$ és a jóindulatú prosztata megnagyobbodás $(\mathrm{N}=246)$ volt. A betegek általános egészségi állapota az EQ-5D-3L index átlaga szerint 0,629 $(\mathrm{SD}=0,331)$ és medián=0,725 volt, az EQ VAS értékek átlaga pedig 59,87 ( $\mathrm{SD}=20,21)$, a medián pedig 60 volt.

A betegek 27,4\%-a részesült informális ellátásban, arányuk 6,5\% (jóindulatú prosztata megnagyobbodás) és 87,2\% (demencia) között mozgott a különböző betegségekben. A betegek több mint egyharmada vett igénybe informális ellátást demencia $(87,2 \%)$, reumatoid artritisz $(49,8 \%)$, szisztémás szklerózis $(38,8 \%)$, arthritisz pszoriatika $(37,7 \%)$ és szklerózis multiplex $(36,8 \%)$ betegcsoportok esetében.

6.2.1.1. Az EQ-5D-3L egyes dimenzióiban problémát jelző betegek informális ellátás igénybevétele

Az Önellátás dimenzióban némi problémát jelentők informális ellátásának heti átlagos óraszáma napi 24 órás limitet alkalmazva $8,13(\mathrm{SD}=16,95)$ óra/hét, 8 órás limittel pedig 7,33 (SD=11,42) óra/hét volt. Az informális ellátásban nem részesülők 15,9\%-a ebben a dimenzióban némi probléma fennállását jelentették. Leginkább a Mozgékonyság, az Önellátás és a Szokásos tevékenységek dimenziókban figyelhető meg, hogy a súlyos probléma/képtelen válaszokat megjelölők esetében rendkívül magas az informális ellátás heti átlagos óraszáma. (11. Táblázat) 
11. Táblázat Az EQ-5D egyes dimenzióiban problémát jelentők informális ellátás igénybe vétele

\begin{tabular}{|c|c|c|c|}
\hline \multirow[t]{2}{*}{ EQ-5D dimenzió } & \multicolumn{2}{|c|}{$\begin{array}{c}\text { Informális ellátásban részesülö } \\
\text { betegek } \\
\text { Informális ellátás heti óraszáma, } \\
\text { átlag (SD) }\end{array}$} & \multirow{2}{*}{$\begin{array}{c}\text { Betegek aránya, akik } \\
\text { nem részesültek } \\
\text { informális ellátásban } \\
(\%)\end{array}$} \\
\hline & $\begin{array}{l}\text { Heti } 56 \text { órában } \\
\text { maximálva }\end{array}$ & $\begin{array}{l}\text { Heti } 168 \text { órában } \\
\text { maximálva }\end{array}$ & \\
\hline \multicolumn{4}{|l|}{ Mozgékonyság } \\
\hline Nincs probléma & $1,36(6,32)$ & $1,74(10,42)$ & $54,30 \%$ \\
\hline Némi probléma & $5,10(10,78)$ & $6,55(20,35)$ & $45,40 \%$ \\
\hline Ágyhoz kötött & $14,62(16,81)$ & $23,23(44,94)$ & $0,30 \%$ \\
\hline \multicolumn{4}{|c|}{ Önellátás (tisztálkodás, öltözködés) } \\
\hline Nincs probléma & $1,73(6,91)$ & $2,38(13,36)$ & $83,40 \%$ \\
\hline Némi probléma & $7,33(11,42)$ & $8,13(16,95)$ & $15,90 \%$ \\
\hline Képtelen & $19,28(20,89)$ & $34,86(56,24)$ & $0,60 \%$ \\
\hline \multicolumn{4}{|c|}{ Szokásos tevékenységek } \\
\hline Nincs probléma & $1,13(5,90)$ & $1,60(11,27)$ & $62,60 \%$ \\
\hline Némi probléma & $5,37(10,65)$ & $6,50(18,53)$ & $35,20 \%$ \\
\hline Képtelen & $11,58(16,18)$ & $17,69(38,23)$ & $2,20 \%$ \\
\hline \multicolumn{4}{|c|}{ Fájdalom/rossz közérzet } \\
\hline Nincs & $1,85(7,69)$ & $2,2911,86)$ & $41,60 \%$ \\
\hline Mérsékelt & $3,73(9,43)$ & $4,74(17,21)$ & $51,20 \%$ \\
\hline Nagyon erős & $7,42(11,95)$ & $10,24(26,80)$ & $7,30 \%$ \\
\hline \multicolumn{4}{|c|}{ Szorongás/lehangoltság } \\
\hline Nincs & $1,79(6,73)$ & $2,18(10,98)$ & $54,40 \%$ \\
\hline Mérsékelten & $4,71(10,98)$ & $6,41(21,64)$ & $40,60 \%$ \\
\hline Nagyon & $6,97(10,81)$ & $7,89(17,62)$ & $5,00 \%$ \\
\hline
\end{tabular}

6.2.1.2. A legrosszabb egészségi állapotban levő betegek informális ellátása

A legrosszabb egészségi állapotban lévő betegek azonosításához megvizsgáltuk, hogy mely betegek rendelkeztek 0 vagy annál alacsonyabb EQ-5D-3L index értékkel, 162 (9,1\%) ilyen beteget azonosítottunk. Közülük 26,1\% reumatoid artritiszben, 17,6\% arthritisz pszoriatikában, 13,9\% demenciában és 13,3\% oszteoporózisban szenvedett. Egyedül az endometriózisban nem volt egyetlen olyan beteg sem, akinek EQ-5D-3L értéke 0 vagy alacsonyabb volt. A legrosszabb egészségi állapotot tapasztalók átlagos 
életkora 62,1 év volt ( $\mathrm{SD}=14,6$ év) és $66 \%$-a volt nő. A 0 vagy annál rosszabb EQ-5D$3 \mathrm{~L}$ index értékkel rendelkezők 31\%-a egyedül élt.

Az informális ellátás tekintetében a legrosszabb egészségi állapottal rendelkezők közül 51 fö (31,5\%) nem kapott informális ellátást, és közülük 15-en egyedül éltek. Az informális ellátás átlagos heti óraszáma a 24 órás limitet használva 18,71 ( $\mathrm{SD}=39,43)$, a 8 órás limitet alkalmazva pedig $11,65(\mathrm{SD}=16,79)$ óra volt. A legmagasabb átlagos heti informális segítség igénybevétel ez esetben demenciában és Parkinson kórban volt megfigyelhető. A 0-nál magasabb EQ-5D-3L index értékkel rendelkezőkkel összehasonlítva látható, hogy a legrosszabb egészségi állapotban élők átlagos informális ellátás óraszáma minden diagnózisban magasabb. (12. Táblázat) 
12. Táblázat A legrosszabb egészségi állapotúak $(\mathrm{N}=165)$ informális ellátása betegségtípusonként*

\begin{tabular}{|l|c|c|c|c|}
\hline \multirow{2}{*}{ Betegség } & \multicolumn{4}{|c|}{ Informális ellátás heti óraszáma/ fó átlag (SD) } \\
\cline { 2 - 5 } & $\begin{array}{c}\text { Legrosszabb egészségi állapotú } \\
\text { betegek** }\end{array}$ & $\begin{array}{c}\text { 0-nál magasabb EQ-5D-3L index } \\
\text { értékkel rendelkezó betegek }\end{array}$ \\
\cline { 2 - 5 } & $\begin{array}{c}\text { Heti 56 órában } \\
\text { maximálva }\end{array}$ & $\begin{array}{c}\text { Heti 168 órában } \\
\text { maximálva }\end{array}$ & $\begin{array}{c}\text { Heti 56 órában } \\
\text { maximálva }\end{array}$ & $\begin{array}{c}\text { Heti 168 órában } \\
\text { maximálva }\end{array}$ \\
\hline Artritisz pszoriatika & $10,72(9,98)$ & $10,72(9,98)$ & $4,52(10,53)$ & $6,03(20,88)$ \\
\hline Pszoriázis & $11,52(17,93)$ & $22,72(51,80)$ & $0,25(1,09)$ & $0,25(1,09)$ \\
\hline $\begin{array}{l}\text { Időskori } \\
\text { makuladegeneráció }\end{array}$ & $1,33(2,65)$ & $1,33(2,65)$ & $2,83(8,26)$ & $2,83(8,26)$ \\
\hline Reumatoid artritisz & $8,02(11,51)$ & $8,99(16,42)$ & $5,35(9,78)$ & $5,93(14,08)$ \\
\hline Szisztémás szklerózis & $2,33(4,04)$ & $2,33(4,04)$ & $5,79(12,34)$ & $7,42(21,99)$ \\
\hline Demencia & $39,63(19,71)$ & $79,21(64,09)$ & $31,21(24,82)$ & $69,77(71,67)$ \\
\hline Oszteoporózis & $4,77(7,31)$ & $4,77(7,31)$ & $1,07(4,85)$ & $1,68(12,61)$ \\
\hline $\begin{array}{l}\text { Jóindulatú prosztata } \\
\text { megnagyobbodás }\end{array}$ & $0^{* * *}$ & $0^{* * *}$ & $1,54(7,05)$ & $1,57(7,32)$ \\
\hline Epilepszia & $1,86(2,73)$ & $1,86(2,73)$ & $2,56(10,34)$ & $5,57(27,02)$ \\
\hline Parkinson kór & $6,33(18,63)$ & $18,78(55,96)$ & $8,87(15,58)$ & $12,07(29,58)$ \\
\hline Skizofrénia & $6,8(9,55)$ & $6,8(9,55)$ & $3,44(6,64)$ & $3,44(6,64)$ \\
\hline Szklerózis multiplex & $5 * * *$ & $5^{* * *}$ & $13,91(16,63)$ & $19,39(36,15)$ \\
\hline
\end{tabular}

*Endometriózisban nem volt egyetlen olyan beteg sem, akinek EQ-5D-3L értéke 0 vagy alacsonyabb volt

**EQ-5D-3L index értékük kisebb vagy egyenlő 0

$* * * \mathrm{~N}=1$ fö

6.2.1.3. Az informális ellátás költsége

Az informális ellátás heti költsége a teljes mintánkban a 24 órás limitet alkalmazva átlagosan $7399(\mathrm{SD}=25648)$ napi 8 órás limitet használva pedig $4696(\mathrm{SD}=11828)$ forint/beteg volt. A Kruslkal-Wallis teszt eredményei alapján a költségek szignifikánsan eltérőek az eltérő diagnózisokban mind elsődleges, mind másodlagos elemzésünk szerint ( $p<0,001$ mindkét esetben). (13. Táblázat) 
5. Táblázat $\mathrm{Az}$ igénybe vett informális ellátás költsége (Ft/beteg/hét) betegségtípusonként

\begin{tabular}{|c|c|c|c|c|}
\hline \multirow[t]{2}{*}{ Betegségek } & \multirow{2}{*}{$\begin{array}{l}\text { Betegszám } \\
\text { (n) }\end{array}$} & \multirow{2}{*}{$\begin{array}{l}\text { Informális } \\
\text { ellátás } \\
\text { igénybe } \\
\text { vevők } \\
\text { aránya }(\%)\end{array}$} & \multicolumn{2}{|c|}{$\begin{array}{c}\text { Az informális ellátást igénybe } \\
\text { vevők informális ellátás költsége, } \\
\text { átlag (SD) }\end{array}$} \\
\hline & & & $\begin{array}{c}\text { Heti } 56 \text { órában } \\
\text { maximálva }\end{array}$ & $\begin{array}{c}\text { Heti } 168 \text { órában } \\
\text { maximálva }\end{array}$ \\
\hline Artritisz pszoriatika & 183 & $37,7 \%$ & $14130(12527)$ & $17288(27474)$ \\
\hline Pszoriázis & 200 & $9,5 \%$ & $8204(12756)$ & $13939(36718)$ \\
\hline Időskori makula degeneráció & 122 & $27,9 \%$ & $9752(12520)$ & $9752(12520)$ \\
\hline Reumatoid artritisz & 255 & $49,8 \%$ & $11168(11350)$ & $12401(17787)$ \\
\hline Szisztémás szklerózis & 80 & $38,8 \%$ & $14203(15489)$ & 18157 (30904) \\
\hline Demencia & 86 & $87,2 \%$ & $37218(20899)$ & $80530(66503)$ \\
\hline Endometriózis & 84 & $9,5 \%$ & $12223(11470)$ & $12223(11470)$ \\
\hline Oszteoporózis & 281 & $14,9 \%$ & $8816(11882)$ & $14132(34695)$ \\
\hline $\begin{array}{l}\text { Jóindulatú prosztata } \\
\text { megnagyobbodás }\end{array}$ & 246 & $6,5 \%$ & $22075(15920)$ & $22561(16995)$ \\
\hline Epilepszia & 100 & $13,5 \%$ & $18876(21152)$ & $39743(61801)$ \\
\hline Parkinson kór & 109 & $31,8 \%$ & $10376(16208)$ & $14642(33074)$ \\
\hline Skizofrénia & 78 & $30,8 \%$ & $11554(7181)$ & $11554(7181)$ \\
\hline Szklerózis multiplex & 24 & $36,8 \%$ & $14374(16120)$ & $19947(35678)$ \\
\hline
\end{tabular}

Az informális ellátás átlagos költsége a női betegek esetében volt magasabb, mint a férfiaké, a 24 és a 8 órás limit alkalmazása esetében is: $4004(\mathrm{SD}=11617)$ és 5144 $(\mathrm{SD}=11971)$ valamint $6827(\mathrm{SD}=26522)$ és $7680(\mathrm{SD}=25116)$ forint. Mann-Whitney $\mathrm{U}$ tesztet eredményei alapján az eltérés mindkét esetben szignifikáns $(\mathrm{p}<0,001$ mindkét esetben).

Az informális ellátás költsége csak az informális ellátást igénybe vevőkre vonatkozóan átlagosan heti $24509(\mathrm{SD}=42281)$ forint/beteg volt a napi 24 órás limitet, és 15646 $(\mathrm{SD}=17100)$ forint a napi 8 órás limitet alkalmazva. A legmagasabb költség demenciában (napi 24 órás limitet alkalmazva $80530 \mathrm{Ft} / \mathrm{beteg} /$ hét és napi 8 órás limittel 37218 Ft/beteg/hét), még a legalacsonyabb költség időskori makula degenerációban (9752 $\mathrm{Ft} / \mathrm{beteg} / \mathrm{hét})$ és endometriózisban (12223 Ft/beteg/hét) volt megfigyelhető. A 8 órás limittel számolva a legalacsonyabb költség azonban a pikkelysömör esetében volt megfigyelhető (8204 ( $\mathrm{SD}=12756) \mathrm{Ft} / \mathrm{beteg} / \mathrm{hét})$. (13. Táblázat) A nemek közötti 
különbség ez esetben nem mutat szignifikáns eltérést a Mann-Whitney U tesztet eredményei alapján ( $p=0,346$ és $p=0,383$ ).

6.2.1.4.Informális ellátás költségét meghatározó tényezők

A változók közötti kapcsolat felderítésére Spearman-féle rangkorrelációt számoltunk. Közepesnél gyengébb, negatív irányú kapcsolat volt megfigyelhető a heti informális ellátás költsége és a betegek életminőségét kifejező EQ-5D-3L index $(r=-0,415, p<0,001)$ valamint EQ VAS érték $(r=-0,326, p<0,001)$ között, azaz a rosszabb állapotban levő betegek több informális ellátást kaptak. Rendkívül gyenge, de szignifikáns kapcsolatot találtunk az informális ellátás költsége és az életkor között $(r=0,094, p<0,001)$, tehát az idősebb betegek több informális ellátásban részesültek, mint a fiatalabbak.

6.2.1.5. Az informális ellátás éves költségei

A 14. Táblázatban az egyes megbetegedésekben az egy beteg egy évre eső informális költségét tüntettük fel a konzervatívabb becslést biztosító napi 8 órás informális ellátás idő limittel számolva. Az egy betegre számolt átlagos éves költségek $125635 \mathrm{Ft}$ (pszoriázis) és 5233482 Ft (demencia) között mozogtak. (14. Táblázat) 


\section{Táblázat Az informális ellátás becsült költsége/beteg/év (HUF) Magyarországon}

\begin{tabular}{|c|c|c|c|}
\hline Betegségek & $\begin{array}{c}\text { Prevalencia } \\
\text { Magyarországon }\end{array}$ & $\begin{array}{c}\text { Becsült átlagos betegszám } \\
\text { Magyarországon }\end{array}$ & $\begin{array}{c}\text { Az informális } \\
\text { ellátás becsült } \\
\text { költsége/beteg/év } \\
\text { (HUF) }\end{array}$ \\
\hline Artritisz pszoriatika & $\begin{array}{c}\text { 0,1-0,3\% (Brodszky et al., } \\
\text { 2009, Brodszky et al., } \\
\text { 2010d) }\end{array}$ & 20000 & 858805 \\
\hline Pszoriázis & $\begin{array}{c}\text { 0,73-2,9\% (OEP, 2009, } \\
\text { Balogh et al., 2014, } \\
\text { Herszényi et al., Rencz et } \\
\text { al., 2015b) }\end{array}$ & 181500 & 125635 \\
\hline \begin{tabular}{|l|} 
Időskori \\
makuladegeneráció
\end{tabular} & $\begin{array}{l}\text { 0,1\%-9,8\% (Péntek et al., } \\
\text { 2017a, Colijn et al., 2017) }\end{array}$ & 115390 & 426510 \\
\hline Reumatoid artritisz & $\begin{array}{l}\text { 0,5\% (Herszényi et al., Kiss } \\
\text { et al., 2005, Lepp-Gazdag et } \\
\text { al., 2002, Péntek et al., } \\
\text { 2007, Dorner et al., 2016) }\end{array}$ & 50000 & 896645 \\
\hline $\begin{array}{l}\text { Szisztémás } \\
\text { szklerózis }\end{array}$ & $\begin{array}{l}0,7-48,9 / 100000 \text { (Minier } \\
\text { et al., 2010) }\end{array}$ & 24800 & 887169 \\
\hline Demencia & $\begin{array}{c}1316 / 100000 \text { (Érsek et al., } \\
2010)\end{array}$ & 131995 & 5233482 \\
\hline Endometriózis & $\begin{array}{l}2-10 \% \text { (Simoens et al., } \\
\text { 2012) }\end{array}$ & 600000 & 187657 \\
\hline Oszteoporózis & $\begin{array}{c}\text { 2,5-21,2\%* (Hernlund et } \\
\text { al., 2013, Raspe et al., } \\
1998)\end{array}$ & $\begin{array}{c}600000 \text { nö és } 300000 \\
\text { férfi* (OEP, 2013) }\end{array}$ & 207363 \\
\hline $\begin{array}{l}\text { Jóindulatú prosztata } \\
\text { megnagyobbodás }\end{array}$ & $\begin{array}{c}\text { férfiak } 8-90 \% \text {-a*** (Rencz, } \\
2012)\end{array}$ & $\begin{array}{c}415000 \text { (Rencz et al., } \\
\text { 2015c) }\end{array}$ & 231446 \\
\hline Epilepszia & $\begin{array}{c}\text { 0,3-0,6\% (EMMI, 2017, } \\
\text { Pentek et al., 2013) }\end{array}$ & 45000 & 393687 \\
\hline Parkinson kór & $\begin{array}{l}\text { 100-200/100 } 000 \text { (OEP, } \\
\text { 2013, Olesen et al., 2012, } \\
\text { Tamás et al., 2014) }\end{array}$ & 20000 (Tamás et al., 2014) & 1366661 \\
\hline Skizofrénia & $1 \%$ (OEP, 2010b) & 100000 & 573097 \\
\hline Szklerózis multiplex & $\begin{array}{c}25-224 / 100000(\mathrm{OEP}, \\
2010 \mathrm{a})\end{array}$ & 7000 & 2123978 \\
\hline
\end{tabular}

*Nem és korcsoport alapján eltérő prevalencia értékek

**A mintánkban oszteoporózisban szenvedő betegek közül 60\%-nak volt valamilyen felnőtkori csonttörése.

***30 éves kor alatt nem jelentkezik, 31-40 év között 8\%, 41-50 év között 20\%, 51-60 év között már 50\%, 61-70 év között 70\%, 71-80 év között 80\%, 80 év fölötti korcsoportban pedig 90\% a jóindulatú prosztata megnagyobbodás előfordulása a férfi lakosság körében 


\subsubsection{Betegségköltség vizsgálatok áttekintése kilenc Közép-Kelet-Európai országban}

\subsubsection{A publikációk kiválasztása}

A duplikátumok ( $\mathrm{n}=246)$ kizárása után 607 potenciális releváns publikációt eredményezett keresésünk, ezek közül 55 nem teljes terjedelemben volt elérhető és további 98 darab review volt. További 282 közlemény nem tartalmazott betegségköltség adatokat, 54 nem egy betegség költségeire fókuszált és 67 darab közlemény valamilyen terápia költségeit jelentette. Összesen 50 közlemény felelt meg a beválogatási kritériumainknak az adatbázisokon folytatott keresések találatai közül.

Kiegészítő, helyi irodalomra vonatkozó keresés eredményeképpen további 8 cikk került beválogatásra (Ausztria: $\mathrm{n}=2$, Bulgária: $\mathrm{n}=5$, Magyarország: $\mathrm{n}=1$ ). Összesen 58 közleményt (melyek esetenként több országra vonatkozó eredményeket közöltek) válogattunk be: Magyarország $(n=24)$, Bulgária $(n=16)$, Lengyelország $(n=11)$, Csehország $(n=10)$, Ausztria $(n=9)$, Szlovénia $(n=4)$, Horvátország $(n=3)$, Szlovákia (n=3) and Románia (n=3).

\subsubsection{A Beválogatott publikációk jellemzői}

A beválogatott közlemények többsége egy országra vonatkozó eredményeket tartalmazott (74\%), azonban 15 kutatás több ország eredményeit jelentette, így összesen 83 országspecifikus eredményt tartalmazott az 58 beválogatott közlemény. A közlemények három negyede angol nyelvü volt ( $\mathrm{n}=44)$ és 5 közlemény kivételével (Georgieva, 2015, Glogovska et al., 2010, Ivanova et al., 2014, Kyuchukov et al., 2015, Todorova, 2007) minden nem angol nyelvü közlemény esetében elérhető volt egy angol nyelvű absztrakt. A publikációk többsége euróban jelentette a költségeket $(n=45,78 \%)$. Összesen 37 publikációban a helyi valutát váltották át euróra, közülük 17 (46\%) közölte az átváltási árfolyamot, 5 (14\%) pedig az árfolyam forrását, 15 (40\%) publikáció pedig egyáltalán nem közölte az átváltásra vonatkozó információkat. A költségadatok helyi valutában való közlése Romániában volt a leggyakoribb (67\%). Összesen 47 (81\%) publikáció jelentette a kutatás finanszírozására vonatkozó információkat. A finanszírozás megjelölésének hiánya Románia ( $\mathrm{n}=2,67 \%)$ és Bulgária $(\mathrm{n}=5 ; 31 \%)$ esetében volt leggyakoribb. 
Klinikai terület szerint az endokrin, táplálkozási és anyagcsere betegségek voltak a leggyakoribbak a publikációkban ( $\mathrm{n}=15$ országspecifikus eredmény), ezt követték a daganatok $(n=12)$, és a fertőző és parazitás betegségek $(n=10)$. (14. Ábra) Összesen 48 különböző betegség került elemzésre az 58 beválogatott közleménybe. 


\section{4. Ábra A publikációkban megjelenő klinikai területek százalékos megoszlása}

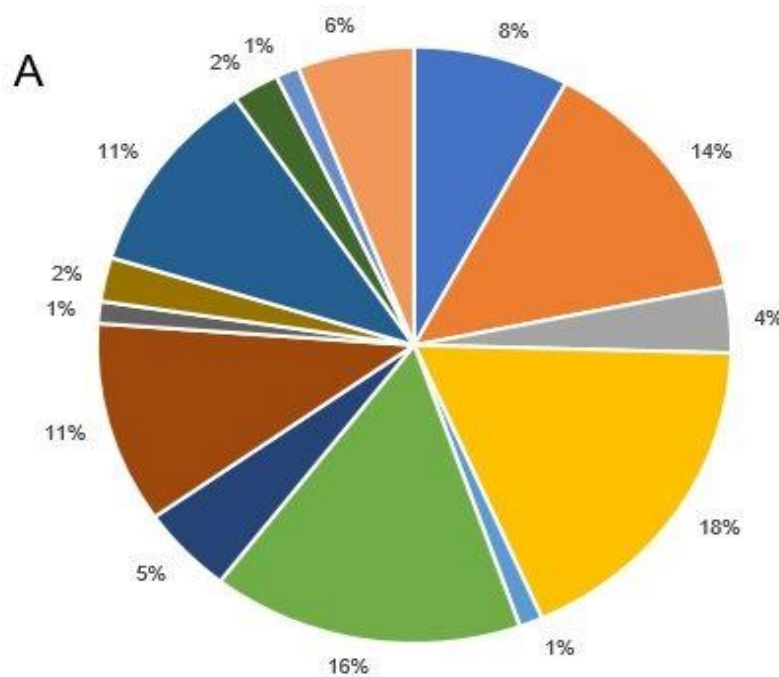

- I. Fertőző és parazitás betegségek

- II. Daganatok

- III. A vér és a vérképző szervek betegségei és az immunrendszert érintő bizonyos rendellenességek

- IV. Endokrin, táplálkozási és anyagcsere betegségek

- V. Mentális és viselkedészavarok

- VI. Az idegrendszer betegségei

- IX. A keringési rendszer betegségei

- X. A légzörendszer betegségei

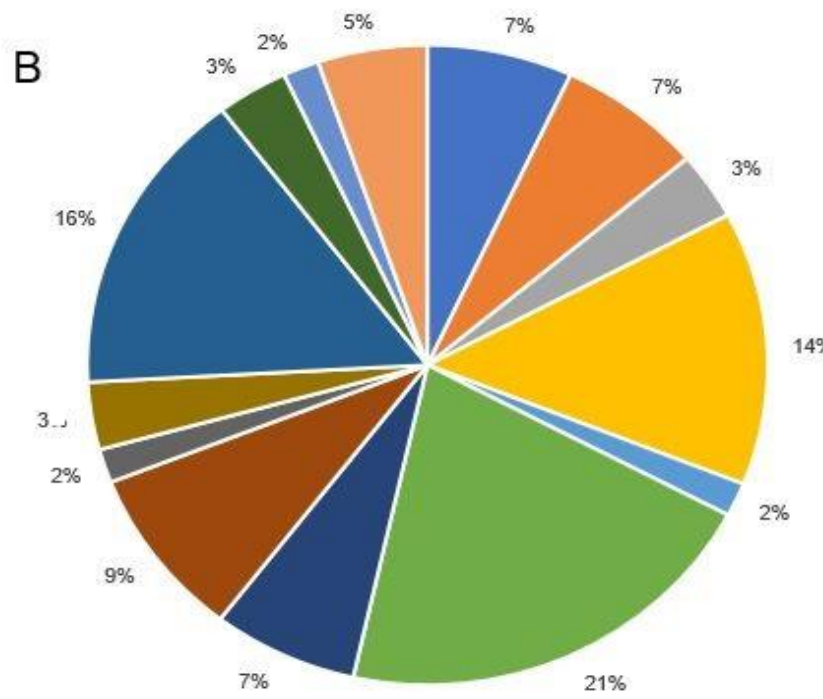

- XI. Az emésztőrendszer betegségei

- XII. A bör és böralatti szövet betegségei

- XIII. A csont-izomrendszer és kötőszövet betegségei

- XIV. Az urogenitális rendszer megbetegedései

=XV. Terhesség, szülés és a gyermekágy

"XVII. Veleszületett rendellenességek,

deformitások és kromoszómaabnormitások

A: Az országspecifikus adatok ICD (BNO) föcsoport szerinti megoszlása ( $n=83)$

$\mathrm{B}$ : A beválogatott közlemények ICD $(\mathrm{BNO})$ főcsoport szerinti megoszlása $(\mathrm{n}=58)$

\subsubsection{Módszerek a beválogatott publikációkban}

Az országok szerinti bemutatást a 15. Táblázatban foglaltuk össze. Az adatok legtöbb esetben retrospektív, önkitöltős kérdöíves kutatásból származtak (48\%), ezt követte a retrospektív „claims data” elemzése (14\%) és a prospektív felmérés (14\%). A 
mintanagyságok $n=2$ (kis cohortok) és $n=127,512$ (nagy lakossági felmérések) között mozogtak. A beválogatott 58 kutatás közül 26 (45\%) jelentett aggregált eredményeket minden fő költség kategóriában (direkt egészségügyi, direkt nem-egészségügyi és indirekt költségek).

A beválogatott kutatások többsége társadalmi perspektívát alkalmazott, (52\%), $17 \%$ pedig a finanszírozó perspektívájából végezte az elemzést. Azokban a publikációkban, ahol közlésre került, a bottom-up (38 \%) és a top-down (21\%) módszerek kerültek leggyakrabban használatra.

Produktivitás veszteségre vonatkozó adatokat 47 (81\%) közleményben közöltek. Ennek értékelésére leggyakrabban az emberi tőke (72 \%) és a súrlódási költség (23\%) módszereket használták. A publikációk 58\%-a egyáltalán nem jelenttette egységköltségeket. (15. Táblázat) 


\section{Táblázat A betegségköltség kutatások jellemzői}

Országspecifikus eredmények száma: $\mathbf{N}=\mathbf{8 3}$; közlemények száma: $\mathrm{N}=\mathbf{5 8}$

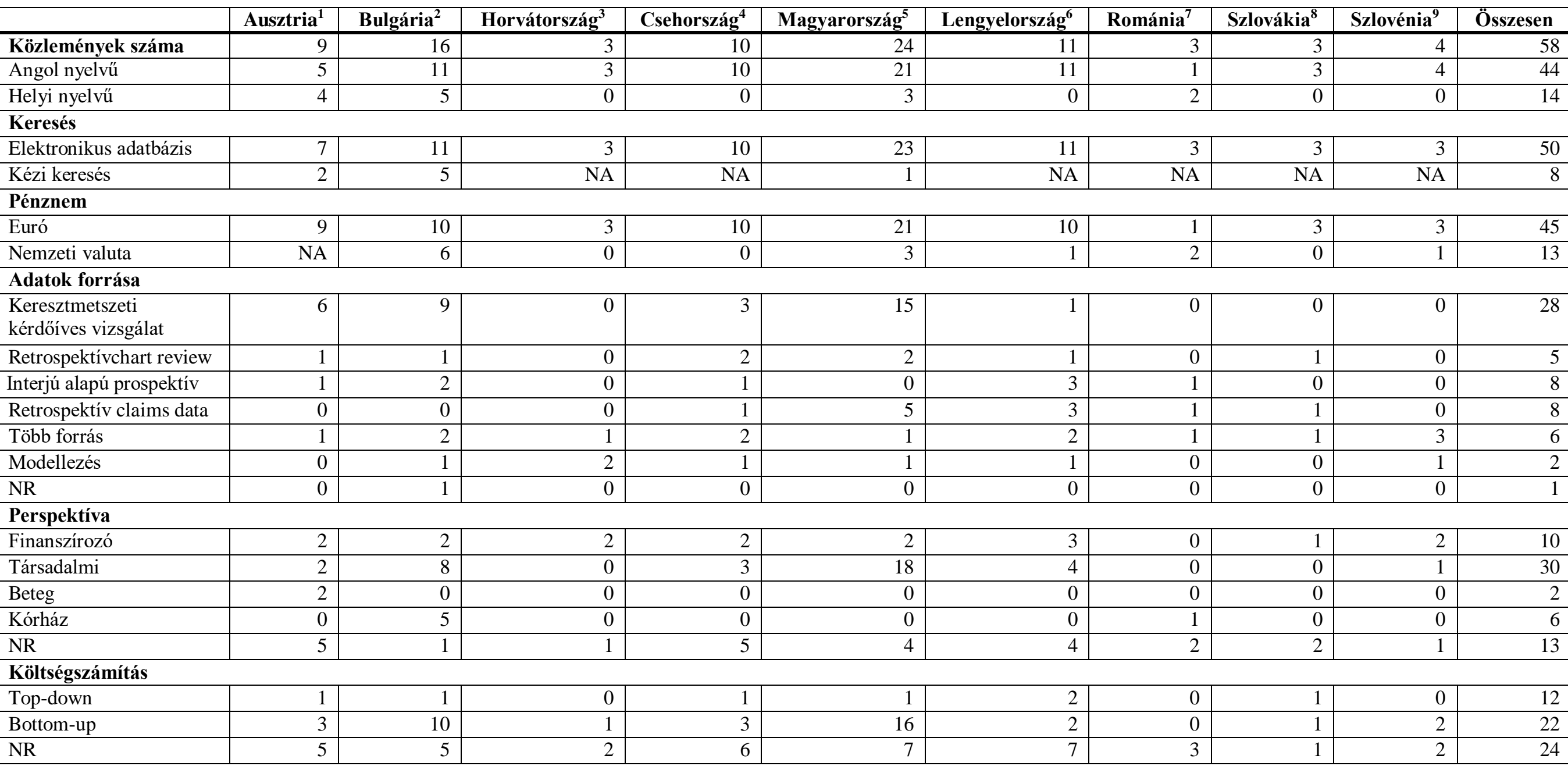




\begin{tabular}{|c|c|c|c|c|c|c|c|c|c|c|}
\hline & Ausztria $^{1}$ & Bulgária $^{2}$ & Horvátország $^{3}$ & Csehország $^{4}$ & Magyarország $^{5}$ & Lengyelország $^{6}$ & Románia $^{7}$ & Szlovákia $^{8}$ & Szlovénia9 $^{9}$ & Összesen \\
\hline \multicolumn{11}{|c|}{ Indirekt költségek számításának módszere } \\
\hline Emberi tőke & 5 & 8 & 0 & 3 & 18 & 7 & 0 & 1 & 1 & 34 \\
\hline Súrlódási & 1 & 1 & 1 & 2 & 1 & 1 & 1 & 1 & 1 & 11 \\
\hline NR & 0 & 0 & 0 & 0 & 2 & 0 & 0 & 0 & 0 & 2 \\
\hline N/A & 3 & 7 & 2 & 5 & 2 & 3 & 2 & 1 & 2 & 11 \\
\hline \multicolumn{11}{|c|}{ Informális ellátás értékelése } \\
\hline Piaci költségek módszere & 0 & 8 & 1 & 0 & 16 & 1 & 0 & 0 & 0 & 5 \\
\hline Haszon-áldozat költségek & 1 & 1 & 0 & 3 & 2 & 1 & 1 & 1 & 1 & 3 \\
\hline NR & 2 & 0 & 0 & 2 & 0 & 1 & 0 & 0 & 0 & 20 \\
\hline Egyéb & 1 & 0 & 0 & 0 & 0 & 0 & 0 & 0 & 0 & 1 \\
\hline N/A & 5 & 7 & 2 & 5 & 6 & 7 & 2 & 2 & 3 & 29 \\
\hline \multicolumn{11}{|l|}{ Finanszírozás } \\
\hline EU & 1 & 8 & 0 & 0 & 9 & 1 & 0 & 0 & 0 & 13 \\
\hline Gyógyszeripar & 5 & 2 & 1 & 3 & 8 & 4 & 1 & 3 & 1 & 11 \\
\hline Kormányzat & 1 & 0 & 0 & 5 & 3 & 1 & 0 & 0 & 0 & 13 \\
\hline Egyéb & 0 & 0 & 0 & 1 & 0 & 0 & 0 & 0 & 0 & 1 \\
\hline Nem finanszírozott & 2 & 1 & 2 & 1 & 4 & 3 & 0 & 0 & 2 & 11 \\
\hline NR & 1 & 5 & 0 & 0 & 0 & 3 & 2 & 0 & 1 & 11 \\
\hline \multicolumn{11}{|l|}{ Költség/beteg } \\
\hline Direkt egészségügyi & 5 & 13 & 1 & 4 & 20 & 5 & 3 & 1 & 1 & 38 \\
\hline Indirekt & 6 & 10 & 2 & 6 & 21 & 9 & 1 & 2 & 3 & 38 \\
\hline Informális ellátás & 4 & 9 & 1 & 5 & 18 & 3 & 1 & 1 & 1 & 29 \\
\hline Teljes & 8 & 13 & 3 & 7 & 23 & 9 & 3 & 3 & 3 & 47 \\
\hline \multicolumn{11}{|l|}{ Egységköltség } \\
\hline Jelentett & 3 & 8 & 1 & 7 & 16 & 5 & 2 & 1 & 2 & 24 \\
\hline Nem jelentett & 6 & 8 & 2 & 3 & 8 & 6 & 1 & 2 & 2 & 34 \\
\hline
\end{tabular}

NA: nincs adat, NR: nem jelentette (not-reported) ${ }^{1}$ (Grabmeier-Pfistershammer et al., 2013, Kobelt et al., 2006, Leal et al., 2016, Prast et al., 2013, von Campenhausen et al., 2009 , Willich

et al., 2006, Dimai et al., 2012, Wagner, 2011, Wagner, 2012); ${ }^{2}$ (Kuhlmann et al., 2016, Iskrov et al., 2015, Jakubczyk et al., 2016, Leal et al., 2016, Valov et al., 2014, Georgieva, 2015,

Glogovska et al., 2010, Ivanova et al., 2014, Kyuchukov et al., 2015, Todorova, 2007, Angelis et al., 2016c, Péntek et al., 2016a, Chevreul et al., 2016a, Lopez-Bastida et al., 2016a, LopezBastida et al., 2016b, Cavazza et al., 2016b); ${ }^{3}$ (Jakubczyk et al., 2016, Leal et al., 2016, Bauer et al., 2014); ${ }^{4}$ (Blahova Dusankova et al., 2012, Jakubczyk et al., 2016, Klimeš et al., 2014,

Leal et al., 2016, Maresova et al., 2016, Mlcoch et al., 2017, Tichopad et al., 2016, Tichopad et al., 2013, Winter et al., 2010, Holmerova et al., 2016); ${ }^{5}$ (Brodszky et al., 2009, Gulácsi et al., 2007, Jakubczyk et al., 2016, Leal et al., 2016, Lopez-Bastida et al., 2016a, Minier et al., 2010, Péntek et al., 2012b, Rencz et al., 2015c, Tamás et al., 2014, Tichopad et al., 2016, Tichopad et al., 2013, Érsek et al., 2010, Péntek et al., 2007, Inotai et al., 2015, Lopez-Bastida et al., 2016b, Kuhlmann et al., 2016, Angelis et al., 2016c, Balogh et al., 2014, Pentek et al., 2013, Péntek et al., 2012c, Cavazza et al., 2016b, Péntek et al., 2012a); ${ }^{6}$ (Czech et al., 2013b, Dubas-Jakobczyk et al., 2016, Jakubczyk et al., 2016, Jaworski et al., 2012, Kawalec et al., 2015, Leal et al., 2016, Lesniowska et al., 2014, Szmurlo et al., 2014, Tichopad et al., 2016, Tichopad et al., 2013, Czech et al., 2013a); ${ }^{7}$ (Leal et al., 2016, Stoicescu et al., 2007, Stambu et al., 2013); ${ }^{8}$ (Leal et al., 2016, Tichopad et al., 2016, Tichopad et al., 2013); ${ }^{9}$ (Dzajkovska et al., 2007, Jakubczyk et al., 2016, Leal et al., 2016, Nerat et al., 2013) 


\subsubsection{Egyes betegségek költségeinek összehasonlítása}

Összesen 83 országspecifikus költségadatot jelentettek a beválogatott publikációk, melyekben 48 eltérő betegség szerepelt. A ritka betegségeken kívül a szklerózis multiplex rendelkezett a legmagasabb betegségteherrel (átlagos egy betegre jutó teljes költséggel) három országban (Ausztria 50.599 euró, Csehország 14.777 euró és Lengyelország 12.343 euró) (Blahova Dusankova et al., 2012, Kobelt et al., 2006, Szmurlo et al., 2014).

Magyarország esetében a skizofrénia (15.187 euró), Bulgáriában pedig terhességi diabétesz (32.263 euró) voltak a legmagasabb költséggel rendelkező betegségek (Todorova, 2007, Péntek et al., 2012c).

Több országot lefedő kutatásokat 9 diagnózisban folytattak (rotavirus gastroenteritis, tüdőgyulladás, húgyhólyagrák, hipoglikémia, Duchenne-féle izomdystrophia, epidermolysis bullosa, Prader-Willi szindróma, cisztás fibriózis, hemofília). Egy olyan kutatás (húgyhólyagrák) szerepelt a beválogatottak közül, amely mind a kilenc ország esetében közölt eredményeket és további egy (hipoglikémia) hat ország esetében. Két közlemény jelentett négy eltérő országra adatokat (rotavirus gastroenteritis és tüdőgyulladás)

A kilenc ország eredményeit tartalmazó húgyhólyagrák kutatásban az egyes országokban alkalmazott módszertanok eltérőek voltak az átlagos költség 7421 euró volt (2320 euró (Bulgária) és 16479 euró (Szlovénia) között ingadozó országonkénti átlagokkal). A hipoglikémia kutatás, amely hat országot foglalt magában és a teljes (egy betegre jutó) társadalmi költség átlagos értéke 11 euró volt (terjedelem: 5 euró (Bulgária) - 18 euró (Szlovénia) (Jakubczyk et al., 2016).

Különálló, de azonos betegségre vonatkozó kutatásokat nyolc diagnózisban találtunk: szklerózis multiplex, demecia, Parkinson kór, reumatioid artritisz, oszeoporózis, krónikus obstruktív légúti betegség, szisztémás szklerózis és diabétesz esetében. A leggyakrabban tárgyalt betegségek a szklerózis multiplex és a diabétesz voltak, egyenként négy kutatásban jelentek meg.

Szklerózis multiplexben, a teljes költségek esetében 4,1-szeres különbséget lehetett Ausztria (50599 euró) és Lengyelország (12343 euró) között (Kobelt et al., 2006, Péntek et al., 2012b). A diabétesz esetében a legmagasabb direkt költséget Magyarországon 
találtuk (1309 euró), még a legalacsonyabbat Bulgáriában (472 euró) (Nerat et al., 2013, Valov et al., 2014).

\subsubsection{Magyarországi egészségügyi online költség katalógus}

\subsubsection{A beválogatott publikációk jellemzői}

A cost of illness publikációkra irányuló keresésünk összesen 105 találatot eredményezett, amelybö1 26 került beválogatásra (Angelis et al., 2016b, Balogh et al., 2014, Brodszky et al., 2009, Chevreul et al., 2016a, Chevreul et al., 2016b, Érsek et al., 2010, Gulácsi et al., Inotai et al., 2015, Jakubczyk et al., 2016, Lopez-Bastida et al., 2016a, Lopez-Bastida et al., 2016b, Minier et al., 2010, Pentek et al., 2013, Péntek et al., 2016a, Péntek et al., 2012b, Péntek et al., 2012c, Péntek et al., 2007, Péntek et al., 2008, Rencz et al., 2015c, Tichopad et al., 2016, Tichopad et al., 2013, Horvath et al., 2014, Leal et al., 2016, Tamás et al., 2014, Angelis et al., 2016a). A cost-effectiveness és budget-impact analysis keresés 79 találatból összesen 15 publikációt válogattunk be (Baji et al., 2012a, Baji et al., 2012b, Brodszky et al., 2014b, Dasbach et al., 2010, Iversen et al., 2015, Mandel et al., 2014, Marada et al., 2016, Nagy et al., 2014, Scuffham et al., 2006, Vokó et al., 2012, Zemplenyi et al., 2016, Boncz et al., 2010, Kovacs et al., 2014, Brodszky et al., 2010c, Daroczi et al., 2016). Összesen 13 technológiaelemzési jelentés került beválogatásra kézi keresésünk eredményeként (Brodszky et al., 2006a, Brodszky et al., 2006b, Brodszky et al., 2007, 2010b, 2010, 2010a, 2011a, 2011, Brodszky et al., 2011b, Brodszky et al., 2011c, Brodszky et al., 2012, Brodszky et al., 2013, Brodszky et al., 2015\{ ) a magyar nyelvü magyarországi irodalom helyi keresése alapján további hét közleményt válogattunk be (Bodnár et al., 2010, Borsos et al., 2006, Brodszky et al., 2010e, Harangozó et al., 2008, József, 2006, Kárpáti et al., 2007, Kósa József et al., 2008). A keresés frissítése 314 találatot eredményezett, amelyből 14 publikáció került beválogatásra (Brodszky et al., 2020, Fejes et al., 2019, Vallejo-Torres et al., 2018, Trapero-Bertran et al., 2018, Németh et al., 2018, Coyle et al., 2018, Bocskai et al., 2018, Baji et al., 2018, Rencz et al., 2017, Péntek et al., 2017b, Péntek et al., 2017c, Meszner et al., 2017, Kobelt et al., 2017, Brodszky et al., 2017). 
A Magyarországi egészségügyi online költség katalógusba összesen 75 darab közlemény került beválogatásra. A 75 publikációban összesen 1298 darab különbözö költség adatot azonosítottunk.

A beválogatott közlemények többsége $(56 \%, n=42)$ cost of illness cikk volt Összesen 13 $13(17,3 \%, 17,3 \%)$ technológiaelemzés jelentés és cost effectiveness analysis került beválogatásra, továbbá egy (1,3\%) budget impact analysis,(Brodszky et al., 2014b) egy (1,3\%) cost-utility analyis (Rencz et al., 2017) és egy (1,3\%) cost-minimization study (Kósa József et al., 2008) és 4 (5,3\%) egyéb típusú publikáció (Péntek et al., 2017c, Baji et al., 2012a, Baji et al., 2012b, Marada et al., 2016) került azonosításra.

A beválogatott közlemények publikáció éve szerinti megoszlását a 15. Ábra mutatja be. A legtöbb azonosított publikációt 2016-ban találtuk ( $\mathrm{n}=14)$, ezt követte $2010(\mathrm{n}=10)$ és 2014, (n=7). A legtöbb magyar nyelvű azonosított publikáció 2010-ben került publikálásra $(\mathrm{n}=5)$. (15. Ábra)

15. Ábra Azonosított publikációk száma az egyes években (publikáció éve és nyelv szerint), $\mathbf{n}(\mathbf{d b})$

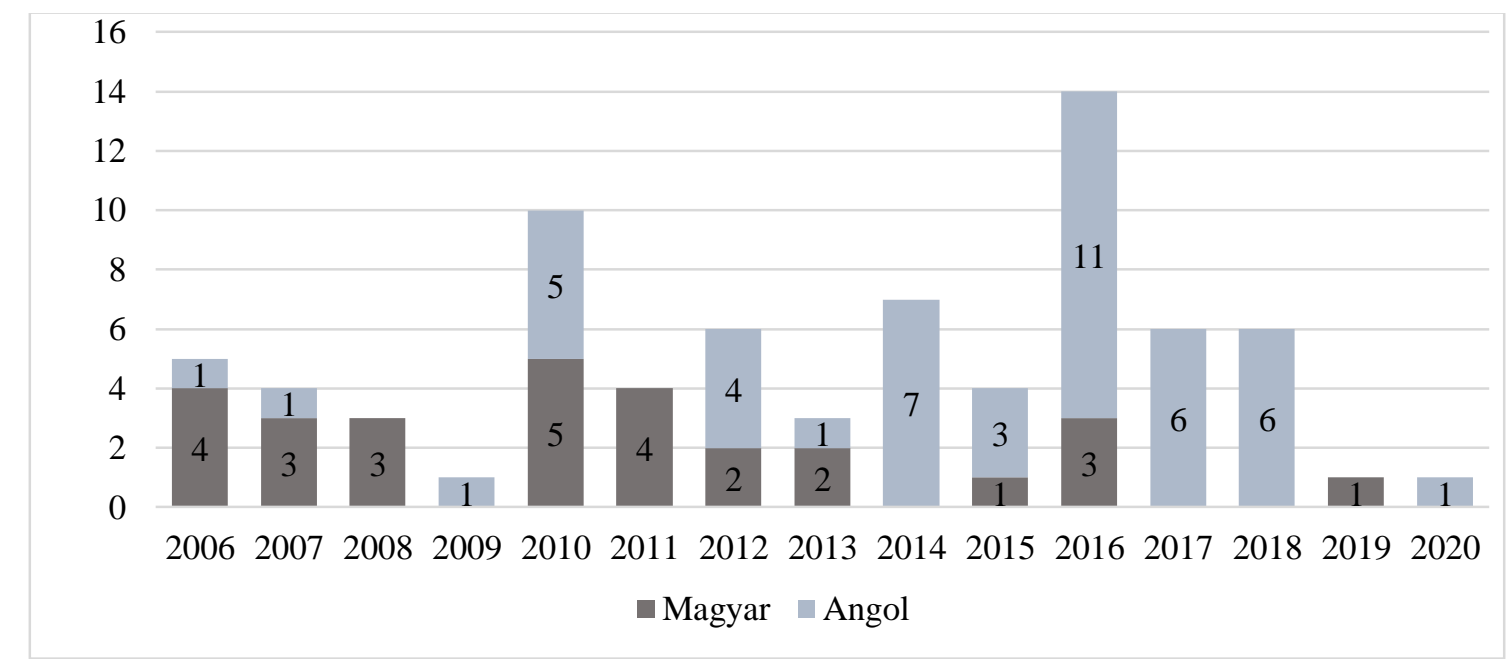




\subsubsection{A publikációkban megjelenő klinikai területek}

A beválogatott publikációk számos, különböző klinikai területet fedtek le. A közlemények osztályozásához ezért a bennük szereplő betegségek/intervenciók értékeléséhez a betegségek nemzetközi osztályozására szolgáló kódrendszert (ICD International Statistical Classifcation of Diseases and Related Health Problems 10th Revision (ICD-10 Version:16)) használtuk (ICD, 2016).

A beválogatott publikációk közül négy darab (6,3\%) publikáció nem specifikus ICD föcsoporthoz köthető volt Ezekben informális payment (n=2) (Baji et al., 2012a, Baji et al., 2012b), eltérő fogászati és szájsebészeti beavatkozások (n=1) (Marada et al., 2016), valamint anesztézia (n=1) (Bocskai et al., 2018) költségei jelentek meg.

A leggyakrabban „A csont-izomrendszer és kötőszövet betegségei” ( $\mathrm{n}=15,20,0 \%)$ (Brodszky et al., 2010b, Brodszky et al., 2011a, Gulácsi et al., 2011, Brodszky et al., 2014b, Brodszky et al., 2009, Brodszky et al., 2006a, Brodszky et al., 2007, Horvath et al., 2014, Lopez-Bastida et al., 2016b, Minier et al., 2010, Péntek et al., 2007), a „Daganatok” ( $\mathrm{n}=8,12,0 \%)$ (Boncz et al., 2010, Brodszky et al., 2017, Dasbach et al., 2010, Inotai et al., 2015, Leal et al., 2016, Vokó et al., 2012, Zemplenyi et al., 2016) és „Az idegrendszer betegségei” ( $\mathrm{n}=8,10,7 \%$ ) (Fejes et al., 2019, Kobelt et al., 2006, Péntek et al., 2012b, Péntek et al., 2017b, Tamás et al., 2014). fócsoportokba tartozó diagnózisok jelentek meg az általunk vizsgált publikációkban. (16. Ábra) 


\section{6. Ábra A beválogatott publikációk klinikai terület szerinti megoszlása (\%) - Betegségek Nemzetközi Osztályozása (BNO)}

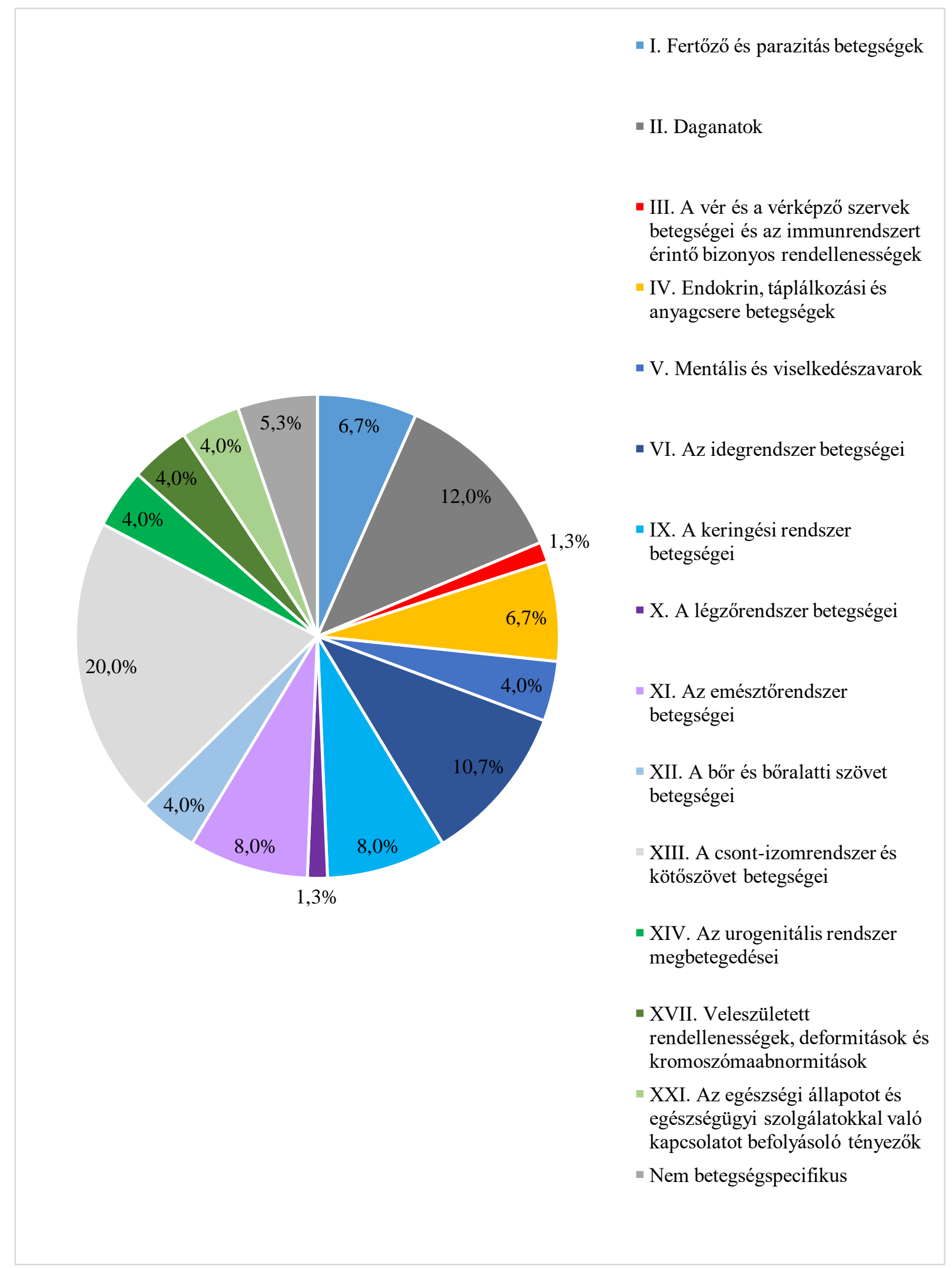


6.2.3.3. A publikációk megoszlása: hazai és Magyarország részvételével zajló nemzetközi kutatások

A publikációk közül 62,7\% (n=47) volt angol nyelvü és 37,3\% (n=28) magyar nyelvü. Összesen 56 publikációnak (74,7\%) első szerzője magyar volt, még 19 közleményé (25,3\%) nemzetközi. Az utolsó szerzők megoszlása: 69,3\% (n=52) magyar és 30,7\% $(\mathrm{n}=23)$ nemzetközi. A publikációk többsége $(\mathrm{n}=51,68 \%)$ hazai, 32\% $(\mathrm{n}=24)$ pedig Magyarország részvételével zajló nemzetközi kutatások voltak.

6.2.3.4. A publikációk Scimago besorolás szerinti megoszlása

A publikációk közül 33 (44\%) Scimago Q1 besorolású folyóiratban jelent meg, 13 (17,3\%) Q2-es folyóiratban (Bocskai et al., 2018, Nagy et al., 2014, Brodszky et al., 2020, Rencz et al., 2017, Baji et al., 2012b, Rencz et al., 2015c, Brodszky et al., 2017, Jakubczyk et al., 2016, Dasbach et al., 2010, Brodszky et al., 2010c, Brodszky et al., 2009, Inotai et al., 2015, Tichopad et al., 2016), 5 cikk (6,7\%) (Marada et al., 2016, Péntek et al., 2008, Zemplenyi et al., 2016, Daroczi et al., 2016, Gulácsi et al.) Q3 és további 7 cikk (9,3\%) Q4-es besorolású volt (Kárpáti et al., 2007, Pentek et al., 2013, Péntek et al., 2012a, Fejes et al., 2019, Harangozó et al., 2008, Bodnár et al., 2010). Összesen 4 cikk (5,3\%) nem listázott magyar nyelvü folyóiratban jelent meg (Brodszky et al., 2010e, Borsos et al., 2006, József, 2006, Kósa József et al., 2008). További 13 technológiaelemzési jelentés került beválogatásra kézi keresésünk eredményeként (Brodszky et al., 2006a, Brodszky et al., 2006b, Brodszky et al., 2007, 2010a, 2010b, 2010, 2011a, 2011, Brodszky et al., 2011b, Brodszky et al., 2011c, Brodszky et al., 2012, Brodszky et al., 2013, Brodszky et al., 2015) melyek nem tartoznak a fenti besorolás szerinti kategóriákba. (17. Ábra) 


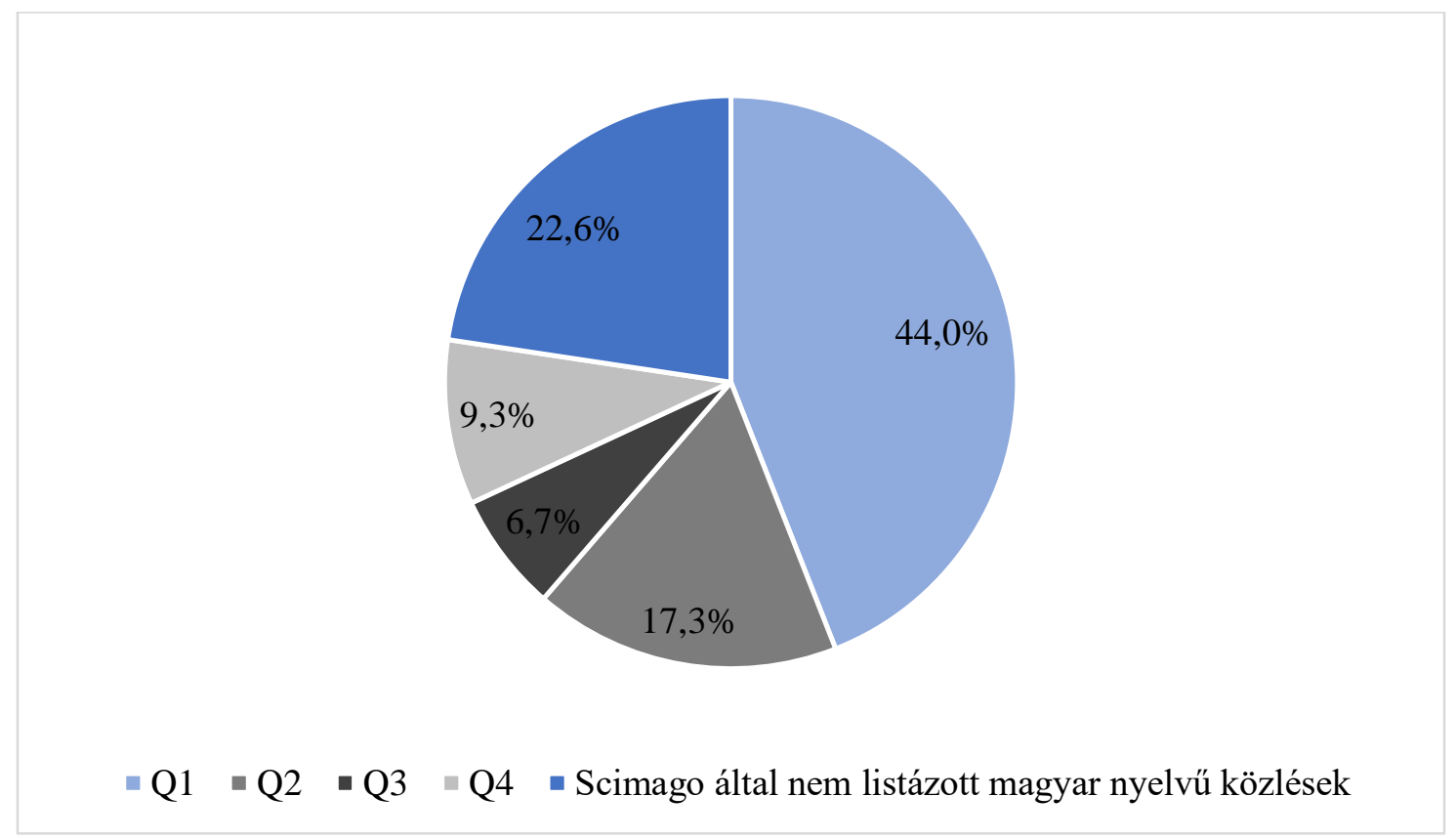

6.2.3.5. Költségadatok a beválogatott publikációkban

A publikációkban szerepelő költségek járó- és fekvőbeteg szektor szerinti megoszlását a 18. Ábra mutatja be. A publikációk többségében $(n=36)$ a fekvő- és járóbeteg szektor valamely költsége szerepelt. 


\section{8. Ábra A fekvő-és járóbeteg költségek megoszlása a publikációkban n (db)}

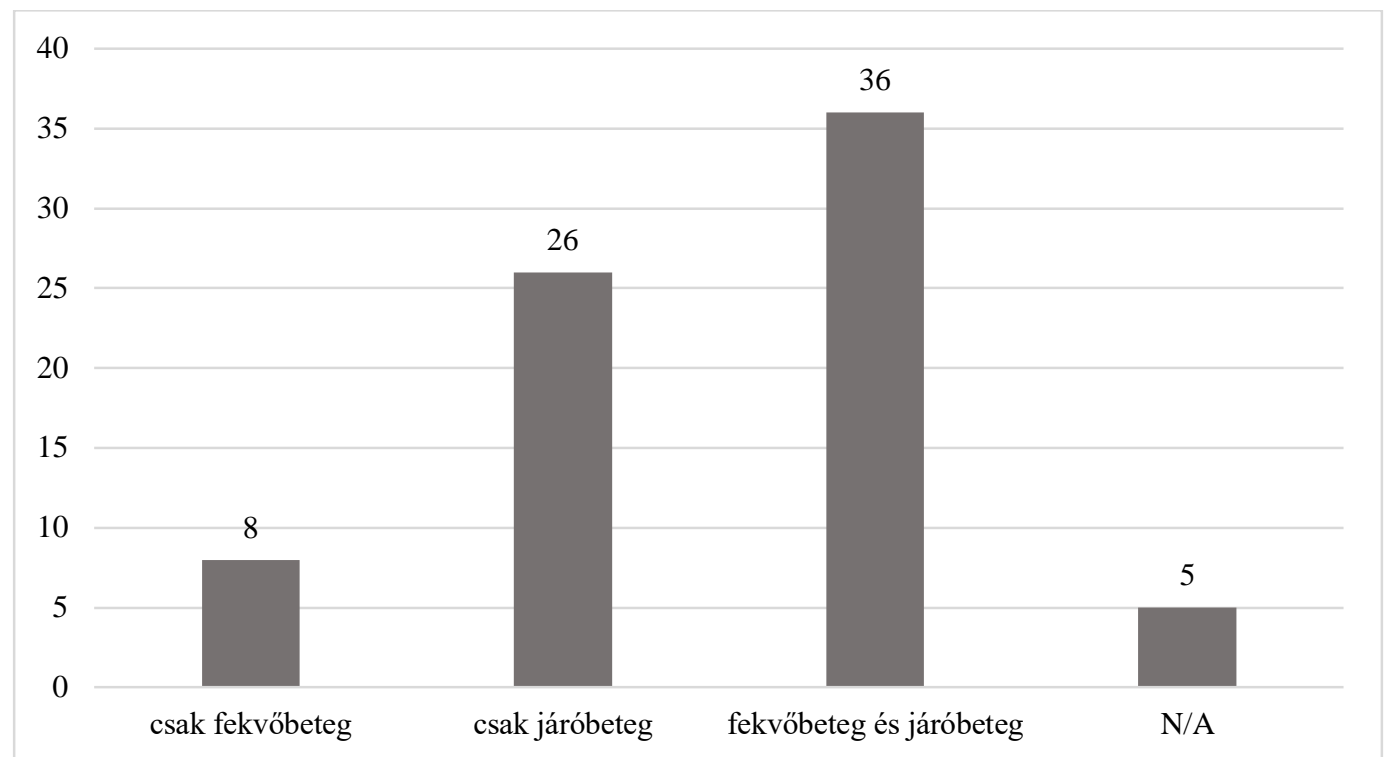

A publikációk több, mint fele (57,3\%, n=43) kizárólag direkt költségeket közölt, azonban az indirekt költséget jelentő publikációk közül három esetben az indirekt költséget a szerzők hospitalizáció és járóbeteg napok után számoltak, amely egy becslés, és nem tekinthető módszertanilag megfelelő indirekt költségszámításnak (Jakubczyk et al., 2016, Meszner et al., 2017, Tichopad et al., 2013). (19. Ábra)

Összesen 6 publikáció esetében a költségadatok több évre vonatkozóan kumulálva (Brodszky et al., 2017) vagy teljes betegpopulációra vonatkozóan (Gulácsi et al., Horvath et al., 2014) vagy jövedelem százalékában (informális payment) (Baji et al., 2012a) került megadásra, ezekben az esetekben az évek számával, beteg/esetszámmal valamint a cikkben szereplö átlagos bérrel számolva becsültük az átlagos költségeket. 


\section{9. Ábra A publikációk megoszlása a bennük szereplő költségek szerint (\%)}

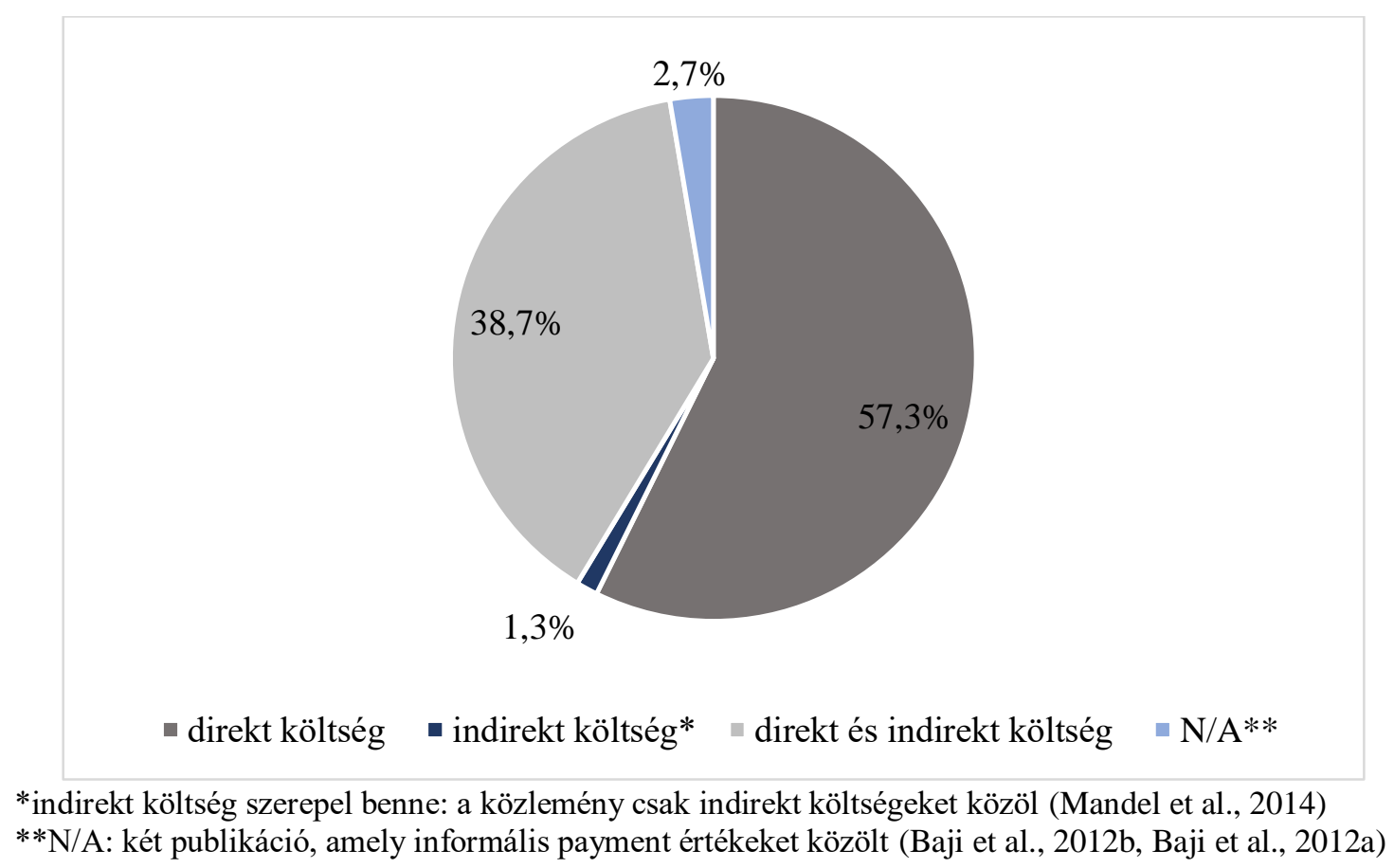

6.2.3.6. Az adatgyüjtés - erőforrás felhasználás - módszertana és egészségügyi közgazdaságtani elemzések módszerei a beválogatott publikációkban

A beválogatott publikációkban rendkívül heterogén adatgyüjtési, költségszámítási és egészségügyi közgazdaságtani módszerek figyelhetők meg, amelyek a következőek:

A beválogatott publikációkban leggyakrabban megjelenő erőforrás felhasználási adatgyüjtési módszertan a retrospektív finanszírozói adatbázis használata, valamint keresztmetszeti vizsgálat voltak, összesen 57 publikáció (76\%) alkalmazta ezeket.

1.retrospektív finanszírozói adatbázis

A NEAK és jogelödeitől származó finanszírozási adatokon alapuló adatgyüjtés. Retrospektív finanszírozói adatbázist 25 publikáció (33,3\%), ebbő1 23 esetben a szerzők kizárólag a NEAK adatok alapján végezték az adott esetben felhasznált egészségügyi erőforrások elemzését használt (Baji et al., 2018, Boncz et al., 2010, Borsos et al., 2006, Brodszky et al., 2011b, Brodszky et al., 2012, Brodszky et al., 2013, Brodszky et al., 2015, Brodszky et al., 2017, Daroczi et al., 2016, Gulácsi et al., Horvath et al., 2014, Inotai et al., 2015, Iversen et al., 2015, Jakubczyk et al., 2016, Kárpáti et al., 2007, Leal et al., 2016, Rencz et al., 2017, Tichopad et al., 2013, Vokó et al., 2012, Colombo et al., 
2011, Brodszky et al., 2014b, Brodszky et al., 2006a, Brodszky et al., Marada et al., 2016, Angelis et al., 2016a, Cavazza et al., 2016a, Cavazza et al., 2016b, Chevreul et al., 2016a, Chevreul et al., 2016b, Lopez-Bastida et al., 2016a, Lopez-Bastida et al., 2016b), valamint két publikáció a retrospektív finanszírozói adatbázis és keresztmetszeti vizsgálat kombinációját használta (Brodszky et al., 2010b, Brodszky et al., 2006a). A különböző szinteken (alapellátás, járó- és fekvőbeteg ellátás, gyógyszerek, orvostechnikai eszközök) történő egészségügyi erőforrás felhasználás a NEAK adatbázisból lekeresésre került a szerzők által. Például, hogy a prosztatarák kezelése során milyen erőforrások kerültek felhasználásara (hány fekvőbeteg ellátásba történő felvétel, milyen gyógyszerfelhasználás történt).

2. retrospektív finanszírozói adatbázis kiegészítve keresztmetszeti vizsgálat eredményével

Két olyan publikációban (2,7\%) azonosítottuk, amely esetén a retrospektív finanszírozói adatbázis használatát, keresztmetszeti vizsgálatból származó eredményekkel kiegészítették a szerzők

\section{3.keresztmetszeti vizsgálat}

Összesen 34 publikációban (45,4\%) szerepelt keresztmetszeti vizsgálat,, amelyből 32 csak keresztmetszeti vizsgálatot és két publikáció pedig a retrospektív finanszírozói adatbázis és keresztmetszeti vizsgálat kombinációját használta (2010, Brodszky et al., 2006a).

A keresztmetszeti vizsgálatok során a szerzők kérdőívben kérdeztek rá az alapellátás, járó-és fekvőbeteg ellátás, valamit gyógyszerek és orvostechnikai eszközök felhasználására és számára (például: a beteg a kérdőív által felmért időtáv során hányszor kereste fel háziorvosát), illetve a társadalombiztosítás által csak részben, illetve egyáltalán nem támogatott szolgáltatások és termékek felhasználására. Ezt követően amennyiben az adott szolgáltatás vagy termék társadalombiztosítás által támogatott volt, a NEAK finanszírozási adataival számoltak. Abban az esetben, ha a szolgáltatás és termék 
nem volt társadalombiztosítás által támogatott, a nagykereskedelmi árat vették alapul a szerzők.

4. retrospektív betegdokumentáció alapú vizsgálat

Intézményi betegdokumentáció alapú, amelyek esetében fekvőbeteg ellátó intézmények adott osztályainak dokumentációinak használata történt. A (fekvőbeteg ellátó) intézményi erőforrás felhasználási mennyiségeket (például: diagnosztikai tesztek, képalkotó vizsgálatok) bekategorizálták, hogy ezek milyen HBCS kategóriába eshetnek és NEAKtól származó költségekkel szorozták fel a szerzők. Ez részletesebb, pontosabb és torzítatlan adatokat eredményezhet, mint kizárólag a NEAK adatok használata, de a helyi osztályos HBCS besorolás nem feltétlen egyezik végleges HBCS besorolással. Összesen $4(\mathrm{n}=5,3 \%)$ publikáció használt betegdokumentáció alapú vizsgálatot (Fejes et al., 2019, Meszner et al., 2017, Tichopad et al., 2016, Vallejo-Torres et al., 2018).

\section{5.szakértői vélemény}

A beválogatott publikációk közül 6,7\% $(n=5)$ hivatkozott szakértői véleményre, mint az adatgyüjtés (erőforrás felhasználás) módszertana (Coyle et al., 2018, Kovacs et al., 2014, Nagy et al., 2014, Németh et al., 2018, Trapero-Bertran et al., 2018). Az erőforrás felhasználást a szakértők becslése alapján kalkulálták a szerzők.

6.mikroköltség-számítás

A mikroköltség-számítás során a felhasznált erőforrások pontos azonosítására, mérésére és forintosítására kerül sor a szerzők által, egy ilyen közleményt azonosítottunk (Zemplenyi et al., 2016).

\section{7.kvázi mikroköltség-számítás}

Beválogatásra került egy kvázi mikroköltség-számítást használó publikáció is, melyben a szerzők tbc miatt kezelt betegek direkt egészségügyi költségeinek számítása során a diagnosztikus beavatkozások finanszírozási értéket a NEAK adatok alapján, a gyógyszerkiadásokat a beteg orvosi dokumentációja alapján vett gyógyszerfelhasználási 
adatok és a beszerzési bruttó ár, a speciális tuberkulocid szereket és a hotelköltségeket az osztályos felhasználás alapján azonosították (Bodnár et al., 2010).

Mikroköltség-számítás és kvázi mikroköltség-számítás 1-1 publikációban (1,3\%) szerepelt (Bodnár et al., 2010, Zemplenyi et al., 2016).

8.publikált klinikai vizsgálaton alapuló költségszámítás

Összesen 7 publikáció (9,3\%) alapult publikált klinikai vizsgálaton (2011a, Brodszky et al., 2010c, József, 2006, Kósa József et al., 2008, Scuffham et al., 2006, Brodszky et al., 2007). Randomizált kontrollált klinikai vizsgálaton alapuló költségszámítás, amely során az RCT-ben leírt betegcsoport esetén, az RCT-ben zajlott folyamatokat és gyógykezelést forintosítják a szerzők. Ez egy első közelítés a gyógyszer vagy más termék piacra lépése elött, de sem az adott ország egészségügyi ellátásának jellemzői, sem a valós körülmények hatása nem kerül figyelembevételre, ezért ezeknek az elemzéseknek az eredményei csak igen nagy óvatossággal alkalmazhatók a gyakorlatban.

\section{9. $\mathrm{KSH}$}

A beválogatásra került publikációk közül egy $(1,3 \%) \mathrm{KSH}$ háztartási panelt használt adatgyüjtésre, ebben a publikációban a háztartások informális egészségügyi kiadásai kerültek felmérésre (Baji et al., 2012a).

Az indirekt költségek becslése is több, eltérő módon jelent meg a publikációkban:

1.indirekt költség számítás: a beteg termelékenységcsökkenése miatt felmerülő közvetett költségek becslése

2. korlátozott indirekt költség számítás: egyes közleményekben az indirekt költséget a szerzők hospitalizáció és járóbeteg napok után számolta, amely az indirekt költségek alulbecsléséhez vezethettek. 


\subsubsection{A publikációkban megjelelő költségek adatforrásai}

Az alkalmazott költségek is számos forrásból származnak, és azonosíthatóságuk is igen eltérő.

\section{NEAK és jogelődjei}

A költség adatok forrásának tekintetében összesen a publikációk 80\%-ában $(n=60)$ szerepelt a Nemzeti Egészségbiztosítási Alapkezelő (NEAK), és jogelődjei a költségadatok forrásaként (alapellátás-, járó és fekvőbeteg ellátás, gyógyszer és orvostechnikai eszköz adatbázisok). Ezek a hivatalos finanszírozó adatok, amelyek alapján kalkulálja az NEAK a valós finanszírozási összegeket.

A NEAK (OEP) adatok kiterjedt használatának a kérdése több fontos kérdést is felvet, ezek közül a legfontosabb az, hogy mi a viszonya az NEAK/OEP finanszírozásnak a valós költségekhez. Ezt a kérdést sajnos nem tudjuk megválaszolni, de valószínüsíthető, hogy az eltérés jelentős, ennek okai a következők:

A NEAK és jogelődeitől származó finanszírozási adatokon alapuló, amely estében felmerül a probléma, hogy a finanszírozási adatok nem tartalmaznak szános egészséggazdaságtani szempontból jelentős tényezőt.

A HBCS értékek számításához szükséges valós kórházi költség-adat gyüjtésre lassan két évtizede nem került sor, az 1993 óra müködő HBCS rendszer, amely 1999 óta nem került átfogó (a csoportok egymáshoz viszonyított arányait megváltoztató) újra kalkulálásra, átfogó kórházi költségfelmérésre pedig utoljára 2008-ban került sor (Balázs et al.).

A HBCS típusú prospektív finanszírozás nem csak finanszírozási mechanizmus, hanem egészségpolitikai eszköz is, nem célja a pontos költségek térítése sem kórházi (kórházak között az azonos beavatkozások költségei is jelentősen eltérhetek) sem országos szinten.

Ezen felül az adatokat több esetben is ismeretlen mértékben módosítják, az egyik esetben a szolgáltató optimalizálja az adatszolgáltatást a NEAK felé, ezt követően a NEAK ellenőrzi, szüri és módosítja is ezeket.

Hazánkban ez a finanszírozási adatbázis áll rendelkezésre, de ezt óvatosan kell kezelni, mert nem ismert a finanszírozási összegeknek a valós költségekhez való viszonya. 
2. Nagykereskedelmi ár

Nagykereskedelmi ár, mint a költségek adatforrása 19 publikációban jelent meg. A szerzők a betegek által vásárolt társadalombiztosítás által nem vagy részben (co-payment) finanszírozott termékek és szolgáltatások, valamint az utazási költség költségeinek becsléséhez használták a megfelelő szolgáltatás vagy termék árát.

\section{3. $\mathrm{KSH}$}

Összesen 29 publikációban jelent a Központi Statisztikai Hivatal meg, mint valamely költségadat forrása, például a produktivitás veszteség becslésének számítása során felhasznált adatként a bruttó jövedelem, valamint a háztartások egészségügyi kiadásainak mérése esetben a KSH háztartás panelvizsgálat (Baji et al., 2012a).

\section{4. Árak más országból}

Két publikációban a gyógyszer árát más országból (UK) származó árral számoltak (Baji et al., 2018, Rencz et al., 2017). Előfordulhat, hogy az elemzés idején az adott gyógyszerre vonatkozóan nem volt hivatalosan megállapított NEAK ár ezért ebben az esetben más országokból származó ár is használható lehet.

\section{Szakértői becslés}

A költségadatok forrásaként szakértői becslésre való hivatkozás két publikációban jelent meg (Kovacs et al., 2014, Meszner et al., 2017). Ebben az esetben nem állt a szerzők rendelkezésére az adott ellátás ára, ezért szakértőket kérdeztek meg.

\section{Nem pontosan azonosítható költségadatok}

A publikációk 9,3\%-ában ( $\mathrm{n}=7)$ a költségadatok forrása többféle adatforrás volt, és ezek mindegyike nem volt pontosan azonosítható.(Bocskai et al., 2018, Coyle et al., 2018, Németh et al., 2018, Trapero-Bertran et al., 2018, Harangozó et al., 2008, Jakubczyk et al., 2016, Vallejo-Torres et al., 2018) Ezek túlnyomórészt Magyarország részvételével zajló nemzetközi kutatások voltak. 


\section{OECD átlagbér}

Egy publikáció esetében az indirekt költségek becslésére OECD átlagbért használtak a szerzők (Meszner et al., 2017).

8. Betegektől származó válaszok alapján

A beválogatottak közül egy publikációban a vizsgálatban szereplő betegek válaszai alapján becsülték az általuk kifizetett informális payment mértékét (Baji et al., 2012b).

\subsubsection{Perspektíva}

A költségszámítás perspektívája a publikáció nagy része esetén feltüntetésre került. Azonban $16(20 \%)$ publikáció esetében nem volt feltüntetve a költségszámítás perspektívája (Brodszky et al., 2011a, Baji et al., 2012a, Baji et al., 2012b, Daroczi et al., 2016, Fejes et al., 2019, Harangozó et al., 2008, Inotai et al., 2015, Iversen et al., 2015, József, 2006, Leal et al., 2016, Meszner et al., 2017, Péntek et al., 2007, Péntek et al., 2017c, Péntek et al., 2008, Tichopad et al., 2013), ezek perspektíváját a publikációk elemzése során, a közölt adatok kategorizálásával azonosítottuk: kilenc esetben társadalmi (Harangozó et al., 2008, Inotai et al., 2015, Jakubczyk et al., 2016, Leal et al., 2016, Meszner et al., 2017, Péntek et al., 2007, Péntek et al., 2008, Tichopad et al., 2013, Baji et al., 2012a), hét esetben pedig finanszírozói perspektívát tudtunk feltételezni (2011b, Bocskai et al., 2018, Daroczi et al., 2016, Fejes et al., 2019, Iversen et al., 2015, Kósa József et al., 2008, Péntek et al., 2017c).

Társadalmi perspektívát összesen 38 közleményben (50,1\%) közöltek elemzést társadalmi szempontból, ebből 29 publikáció esetén feltüntetésre került a társadalmi perspektíva $(38,7 \%)$. Kilenc esetben pedig (12\%) esetben a társadalmi perspektívát az adatok elemzése során azonosítottuk (Harangozó et al., 2008, Inotai et al., 2015, Jakubczyk et al., 2016, Leal et al., 2016, Meszner et al., 2017, Péntek et al., 2007, Péntek et al., 2008, Tichopad et al., 2013, Baji et al., 2012a).

Finanszírozói perspektívából 37 közlemény (49,3\%) készült. Ebből 22 közleményben (29,3\%) tüntették fel a szerzők egyértelmüen a költségszámítás perspektíváját. Emellett 
két publikáció (2,7\%) az „egészségügyi rendszert” (Coyle et al., 2018, Marada et al., 2016), két publikáció (2,7\%) a „társadalombiztosítást” (Horvath et al., 2014, Kárpáti et al., 2007), három publikáció (4\%) a szolgáltatót (Bodnár et al., 2010, Vallejo-Torres et al., 2018, Zemplenyi et al., 2016) és egy közlemény (1,3\%) a kormányzatot (Scuffham et al., 2006) jelölte meg, mint perspektívát. Ezeket a közölt adatok elemzése során finanszírozói perspektívának tekintettük. Hét esetben pedig $(9,3 \%)$ nem volt feltüntetve a költségszámítás perspektívája, a finanszírozói perspektívát az adatok elemzése során azonosítottuk (2011, Bocskai et al., 2018, Daroczi et al., 2016, Fejes et al., 2019, Iversen et al., 2015, Kósa József et al., 2008, Péntek et al., 2017b). 


\section{MEGBESZÉLÉS ÉS KONKLÚZIÓ}

\section{1. Életminőség mérés}

\subsubsection{Az európai, lengyel, szlovén és UK EQ-5D-3L értékkészlet összehasonlítása 18 krónikus betegségben}

Összesen 18 eltérő diagnózisban elemeztük a négy különböző EQ-5D-3L értékkészlettel számított index értékek alakulását és ezen eltérésének potenciális hatásait- Elemzésünk számos eltérő betegséget foglalt magában. Magyarországi betegpopulációból származó keresztmetszeti minták használatával (Rencz et al., 2016, Brodszky et al., 2009, Brodszky et al., 2010d, Érsek et al., 2010, Simoens et al., 2012, Pentek et al., 2013, Hever et al., 2015, Rencz et al., 2015a, Balogh et al., 2013, Tamás et al., 2014, Rencz et al., 2014, Péntek et al., 2007, Péntek et al., 2012b, Minier et al., 2010, Péntek et al., 2012c, Péntek et al., 2012a, Balogh et al., 2014, Pulay et al., 2016). Olyan értékkészleteket elemeztünk, amelyeket gyakran használnak vagy potenciálisan használhatóak egészséggazdaságtani elemzésekben a Közép-Kelet-Európai régióban (Rencz et al., 2016). Betegszintű adatok segítségével hasonlítottuk össze a négy értékkészlettel számolt hasznosság értékeket.

Korábbi kutatások más TTO és VAS alapú értékkészleteket hasonlítottak össze több országban például lakossági minta, modellezés, vagy egy specifikus betegpopuláció elemzésének segítségével (Mozzi et al., 2016, Endarti et al., 2018, Bernert et al., 2009) (Clemens et al., 2014) (Olsen et al., 2018). Továbbá számos korábbi kutatás hasonlított össze értékkészleteket az egyes EQ-5D-3L profilokban (Kiadaliri, 2016, Golicki et al., 2010, Brooks et al., 2003). Jelenlegi kutatásunkban két eltérő módszeren (TTO és VAS) alapuló értékkészleteket hasonlítottunk össze Közép-Kelet-Európai régióból származó, több, eltérő betegségben szenvedő betegpopuláción.

Jelentős eltéréseket találtunk a diagnózis, korcsoport és betegségsúlyosság szerinti elemzésünkben. Az átlagos EQ-5D-3L index érték eltérés 0,265 volt PD diagnózisban és 0,187 az 55 évnél idősebbek csoportjában. A betegségteher (DB) páronkénti összehasonlítása során inkonzisztens eredményekre jutottunk az eltérő módszertanon 
alapuló (TTO és VAS alapú) értékkészletek összehasonlításában. Az azonos módszertanon alapuló értékkészletek összehasonlításakor azonban konzisztens eredményeket kaptunk.

Eredményeink igazolják a korábbi kutatásokban megjelenő feltevést, miszerint módszertanon alapuló eltérések figyelhetőek meg az EQ-5D-3L értékkészletekben (Olsen et al., 2018, Bernert et al., 2009). Az EQ-5D-3L értékkészletek közötti eltérés szignifikáns eltéréshez vezethet a hasznosságértékekben, ezzel befolyásolhatják az egészségnyereségek értékelését. Egy kiragadott példát tekintve, ha egy beteg egészségi állapot a '22222' (minden dimenzióban mérsékelt probléma) állapotból az '11111' (tökéletes egészség) állapotába mozdult el (például valamely új terápia hatásának köszönhetően), a QALY nyeresége 0,685 lenne a szlovén, még mindössze 0,284 a lengyel értékkészlettel számolva. A lehető legrosszabb ('33333’) állapotból a '22222’ állapotba való elmozdulás 1,239 QALY nyereséget jelentene a lengyel értékkészlettel, azonban csak 0,555-öt az európai értékkészlettel kalkulálva.

Az értékkészletek közötti jelentős eltérések miatt az értékkészlet megválasztása nagy mértekben befolyásolhatja az egyes állapotok hasznosságát, és ezzel befolyásolhatja az egészségpolitikában és finanszírozási döntések során felállított prioritásokat.

Kiemelten fontosak lehetnek ezek a tényezők a Közép-Kelet-Európai régióban, ahol sok esetben nem érhetőek el helyi adatok és az egészséggazdaságtani elemzések sokszor külső adatforrásokra kell támaszkodjanak (Gulácsi et al., 2016). Az országspecifikus értékkészletek kialakítására való törekvés egyre növekvő mértékü, hiszen a helyi értékkészletek jobban meg tudnák jeleníteni az adott populáció preferenciáit (EuroQol, 2019).

Kutatásunknak azonban bizonyos korlátai voltak. A kutatásunkban szereplő betegek nem minden esetben reprezentálják az adott betegségben szenvedő teljes betegpopulációt. További kutatások több betegség bevonásával az egyes értékkészletekkel megállapított EQ-5D-3L index értékek eltéréseinek jobb és mélyebb megértését segítené elő.

Összefoglalva megállapítható, hogy számos krónikus betegségekben szenvedők körében, eltérő értékkészleteket összehasonlítva felfedezhető az értékkészlet-választás fontossága 
az egészséggazdaságtani elemzések, és az egészségpolitikai döntések elökészítésnek folyamata során.

Közpolitikai jelentőség

Az értékkészlet-választás fontos tényező az egészséggazdaságtani elemzések, és az egészségpolitikai döntések előkészítésnek folyamata során. Az egészségi állapotok hasznosságának ismerete elengedhetetlen az egyéni és társadalmi hasznok megismeréséhez, a 'fair' forrásallokáció tervezéséhez, hiszen így biztosítható az, hogy mindenki transzparens módon az egészségügyi szükségleteinek megfelelő ellátásban részesüljön. A kutatás eredményei rámutatnak arra, hogy az életminőség területén nem hagyhatók figyelmen kívül az ország specifikus különbözőségek. Ahhoz, hogy hazánkban is, a fejlett országok gyakorlatához hasonlóan, a hazai lakosság preferenciájának megfelelő módon történjék az egészségügyi források allokációja, megfelelö értékkészlet használata szükséges.

Ennek segítségével biztosítható, hogy az egészségügy a valóban fennálló lakossági szükségleteket elégítse ki és megfelelőbbé és átláthatóbbá válnak a forrás allokációs döntések és az információs aszimmetria is kontrollálható.

\subsubsection{A DLQI kérdőív „,nem releváns” válaszainak részletes elemzése}

Jelen kutatásunkban a DLQI kérdőívben megjelenő NRR válaszok előfordulását elemeztük pszoriázisban szenvedő betegek körében. Eredményeink azt mutatták, hogy a DLQI összpontszám, a PASI pontszám, és számos szocio-demográfiai tényező befolyásolta, hogy egy beteg hány darab NRR választ jelölt meg.

A betegek 38,8\%-a legalább egy NRR választ jelölt meg, továbbá a 6 és 20 közötti DLQI pontszámmal rendelkezők közül többen voltak azok a betegek, akik NRR választ jelöltek, mint akik nem. Ez arra utal, hogy a DLQI-ban megjelenő bizonyos területek nem jelentősek a pszoriázis betegek jelentős részsének. Továbbá, mivel a NRR válaszok 0 pontszámot kapnak, a NRR válaszok gyakoribb előfordulása alacsonyabb DLQI összpontszámhoz vezetne. Kutatásunk eredményei azonban azt mutatják, hogy minél magasabb a DLQI összpontszám, a betegek annál több NRR választ jelölnek meg. A NRR 
válaszok nagy gyakorisága és a DLQI összpontszám és NRR válaszok száma közötti fordított összefüggés validitási probléma fennállására utal. Az NRR válasszal rendelkező kérdések elhagyásával és az így kapott pontszám 0-30-as skálára való átváltásával a 166 NRR válasszal rendelkező beteg átlagos DLQI összpontszáma 7,23-ról 8,94-re növekedve ( $\mathrm{p}<0,001)$. Ez a növekedés még jelentősebb a 65 évnél idősebbek csoportjában $(\mathrm{n}=46)$, ahol 7,41 pontról 10,15 pontra változna az átlag $(\mathrm{p}<0,001)$.

Megfigyeltük, hogy bizonyos szocio-demográfiai jellemzők szerinti csoportok gyakrabban választották a NRR választ. Mintánkban a nők, az idősek, a nem teljes munkaidőben foglalkoztatott és az alacsonyabb iskolázottsággal rendelkezők voltak ezek a csoportok.

Korábbi kutatások eredményeihez hasonlóan, a NRR válasz leggyakrabban a sport, szexuális nehézségek, valamint a munkára vonatkozó kérdésekben jelentek meg (Hahn et al., 2001, Mork et al., 2002, Twiss et al., 2012, Ferraz et al., 2006, Khoudri et al., 2013, Mazzotti et al., 2005, Mayrshofer et al., 2005). Ezek a kérdések kevésbé relevánsak az idősebb pszoriázis betegek számára, mint a fiataloknak. A pszoriázis azonban egy élethosszig tartó, krónikus betegség, és az ebben használt életminőség mércékre tekintve fontos, hogy minden korosztályra alkalmazhatóak legyenek.

Kutatásunk számos limitációval rendelkezett. A nagy mintaelemszám ellenére egyes kérdések esetében kevesebb, mint 10 NRR válasz volt és kevés beteg jelölt meg 2-nél több NRR választ. Továbbá nem rendelkezünk információval arra vonatkozóan, hogy a mintánkban szereplő betegek különbséget tudtak-e tenni az NRR és az „egyáltalán nem” válaszok között, amely megjelenő hibás értelmezés a kérdőív tekintetében korábban megvilágított probléma lehet (2017).

Két további kutatás is vizsgálta az NRR válaszok alakulását a DLQI kérdőívben (Bashyam et al., 2019, Langenbruch et al., 2019). Langenbruch és munkatársai 1240 pszoriázisban szenvedő betegből álló mintán elemezték a DLQI válaszokat. A betegek 48,7\%-a nem jelölt egy NRR választ sem. Bashyam és munkatársai szintén kiemelték a „nem releváns válaszok” választása során felmerülő problémát, miszerint a válaszadók nem minden esetben tudják elkülöníteni, hogy a betegségük akadályozza meg őket a tevékenységben vagy egyáltalán nem érdeklődtek a tevékenység végzése iránt (Bashyam et al., 2019, Langenbruch et al., 2019). 
Közpolitikai jelentőség

A betegségspecifikus kérdőívek sok esetben terápiás indikáció felállítására, és egy adott terápia hasznának értékelésére használatosak. Azaz ezeknek a kérdőíveknek az eredményei befolyásolhatják, hogy hányan és milyen egészségi állapotban levő (szükséglet) egyén fog egy adott terápiát kapni. Ebben a kutatásban azt láttuk, hogy a betegnek a terápiához való hozzáférését, az egészségi állapotán kívül más, az egyén társadalmi-gazdasági, nemi, életkori és földrajzi jellemzői is befolyásolhatják. Ezt a közfinanszírozott egészségügyi ellátás keretei között nem tartjuk elfogadhatónak, hiszen ellentmond annak a közpolitikai célnak, hogy a beteg a betegségétől függő szükségletei alapján kapjon egészségügyi ellátást.

A hozzáférés, ki fér hozzá és milyen egészségi állapotban, hatással van a költséghatékonyságra és ez az adat az adott terápia költségvetési hatásának vizsgálata során rendkívül jelentős. A költség-hatékonyság és a költségvetési hatás pedig olyan adatok amelyek alapján országos szinten dől el hogy az adott beteg az adott orvossághoz a közfinanszírozott egészségügy keretein belül hozzáfér-e vagy sem.

\subsubsection{A magyarországi lakosság egészségi állapota és munkaképessége}

Kutatásunk célja a magyarországi lakosság egészségi állapotának és munkaképességének felmérése volt standard mérőmódszerek alkalmazásával. Az idősödő társadalom és az egyre hatékonyabban müködő egészségügyi rendszer fennállása mellett a finanszírozás, az egészségügyi szolgáltatások tervezése és biztosítása, valamint a krónikus betegségben szenvedő betegek fenntartható foglalkoztatása fő prioritássá vált. A költséghatékonysági elemzések, amelyek helyi (országspecifikus) adatokon alapszanak szükségesek a döntéselőkészítés és az új technológiák értékelése során. A fenntartható foglalkoztatás megteremtése és az egészségpolitikai döntéshozatal folyamatának támogatása érdekében fontos információt jelenthetnek a helyi adatok, egy lakosság egészségi állapotáról, munkatermelékenységéröl és a két tényező közötti összefüggések ismerete. Keresztmetszeti kérdőíves felmérést végeztünk a magyar lakosság körében, reprezentatív minta bevonásával. Kutatásunkban standard mércéket használtunk. Összesen 2023 válaszadó vett rész kérdőíves felmérésünkben. 
Az EQ-5D-5L index érték átlaga 0,92 (SD=0,15), az EQ-VAS átlaga 81,6 (SD=17,4) volt a résztvevők körében. A WPAI, más tevékenységekben aktivitás csökkenés átlagos értéke 9,5\% ( $\mathrm{SD}=21,0 \%$ ), az összesített termelékenységveszteség munkavégzés közben átlagos értéke 7,7\% ( $\mathrm{SD}=20,9 \%)$ volt, az absenteeism és a presenteeism esetében az átlagos értékek 3,6\% (16,4\%) és 4,4\% (14,2\%) voltak rendre.

Wrona és munkatársai az egészségi állapot miatt felmerülő termelékenységcsökkenést (WPAI-GH kérdőívvel felmérve) elemezték a lengyel lakosság esetében és eredményeik más európai országokéhoz hasonlóak voltak. Az eltérő jövedelemmel rendelkező csoportok vizsgálata során az fedezték fel, hogy az összesített termelékenységveszteség munkavégzés közben magasabb értékkel rendelkezett a magasabb jövedelmű háztartások esetében (Wrona et al., 2010). Jelen kutatásunkban a háztartás nettó havi jövedelme és a más tevékenységekben tapasztalt aktivitás csökkenése között találtunk szignifikáns kapcsolatot $(r=-0,277, p=0,000)$.

Mandel és munkatársai szintén a produktivitás veszteséget elemezték Magyarországon, gyulladásos bélbetegségekben szenvedők körében és azt találták, hogy a presenteeisem és az absenteeism gyakran elforduló probléma volt a teljes- vagy részmunkaidőben foglalkoztatott betegek esetében (Mandel et al., 2014). Egy másik, szintén Magyarországon folyatott kutatásban Péntek és munkatársai szintén az EQ-5D és WPAI kérdőíveket használták az egészséggel összefüggő életminőség és produktivitás mérésére a hiperaktív hólyagszindrómában szenvedő nők körében. Péntek és munkatársai eredményei alapján a presenteeism rendkívül jelentős volt a vizsgált betegek körében (Péntek et al., 2012a).

Közpolitikai jelentőség

A terápiák nem csak a klinikai tünetetek megszüntetése miatt rendkívül fontosok, hanem az egyén életminőségének, társadalmi képességeinek és munkaképességeinek helyreállítása szempontjából is. Ezekre a tényezőkre vonatkozóan azonban nem állnak rendelkezésre rutinszerűen gyüjtött adatok, ezért a terápiák teljes hasznának ismeretéhez, ezeket egészséggazdaságtani elemzésekkel szükséges vizsgálni. Az optimális forrásallokáció és döntéshozatal érdekében rendkívül fontos a terápiák hasznának teljeskörü megismerése. 


\subsubsection{Informális ellátás és meghatározó tényezői krónikus betegségekben: magyarországi kutatások összehasonlító elemzése}

Kutatásunkban 14 krónikus betegségben végzett korábbi felméréseink betegszintű adatainak elemzésével vizsgáltuk az informális ellátást hazai betegek körében.

A betegek 27\%-a kapott segítséget nem fizetett segítőtől, az informális ellátás ideje átlagosan heti 7,5 óra volt a teljes betegmintát tekintve és szignifikánsan eltért a diagnózisok között. Legmagasabb arányban demenciában, négy gyulladásos immunológiai betegségben (RA, SSc, AP és SM) és Parkinson kórban részesültek ilyen típusú gondozásban. (10. Ábra) A legmagasabb óraszámokat is ezekben a betegségekben találtuk. (11. Ábra) A demenciában szenvedők másokra utaltsága hazánkban is jelentős, eredményeink összhangban vannak a nemzetközi adatokkal (Costa et al., 2013). Demenciában a többi diagnózishoz képest kiugró eredmény hátterében az is állhat, hogy az informális ellátás idejét egy demenciára specifikus kérdőívvel (un. RUD kérdőív) mérték fel, amely részletesen rákérdez a különböző tevékenységekre és a beteg felügyeletére fordított időre, míg a többi betegségben egyszerủen a napi, illetve heti óraszámot kérdezték meg. Másik eltérés, hogy demenciában a beteget gondozó hozzátartozók válaszolták meg a kérdéseket, nem maguk a betegek. Gondozók és gondozottak különböző módon ítélhetik meg egyrészt, hogy milyen tevékenységek tartoznak az informális ellátásba, másrészt hogy mennyi időt fordított a gondozó (vagy gondozók) rá. Az informális ellátás felmérésének módszertana nem egységes a szakirodalomban, az összehasonlíthatóság miatt egyre szélesebb körben alkalmaznak betegség-független standard kérdőíveket (például a iMTA Valuation of Informal Care Questionnaire - iVICQ), ezek használata megfontolandó hazai felmérésekben is (Hoefman et al., 2011). Parkinson kórban az informális ellátás más országokban is jelentősnek bizonyult, a Cseh Köztársaságban és Oroszországban átlagosan heti 10 óra volt, de jóval magasabb óraszámokat is közöltek (Bovolenta et al., 2017, RodríguezBlázquez et al., 2015). Gyulladásos immunológiai betegségekben (RA, AP, SM, SSc) jellemzően magas volt a betegség-aktivitás, ez részben magyarázza a magas informális ellátást (Brodszky et al., 2009, Minier et al., 2010, Péntek et al., 2012b, Péntek et al., 2007). Érdemes lenne következő kutatásokban megvizsgálni, hogy a költséges, de hatékony biológiai gyógyszerek elterjedése (különösen RA-ban és AP-ben) hogyan 
változtatta meg az informális ellátást és annak költségeit, erre a finanszírozó rutinszerüen nem gyüjt adatokat (Gulácsi et al., 2016).

Az informális ellátásban részesülők átlagos életkora és betegség fennállása csak kissé volt magasabb, mint az informális ellátásban nem részesülöké. Több mint kétszer annyi nő vett igénybe informális ellátást, mint férfi, miközben a teljes mintában a nők aránya csak kissé volt magasabb. (8. Táblázat) A lehetséges okok között (pl. betegségsúlyosságban különbség a nemek között a mintákban, nemek közötti prevalencia eltérések, csak férfiakat érintő jóindulatú prosztata megnagyobbodás bevonása) gondolni kell arra is, hogy a demencia kivételével a betegek önbevallásán alapultak a felmérések. Attól függően, hogy a betegség előtt milyen tevékenységeket végzett valaki (pl. fözött, mosott, takarított, ügyintézett vagy ellenkezöleg, nem vett érdemben részt ezekben a munkákban), másként ítéli meg, hogy betegen mit nem tud elvégezni és miben igényel segítséget mástól (Hoefman et al., 2013). Bár az elemzésbe bevont kutatások ezt nem vizsgálták, lehetséges, hogy a nők nagyobb arányban lettek képtelenek ellátni korábbi szokásos otthoni teendőiket a betegség miatt, és ezért többen élték meg úgy, hogy más segítségére szorulnak.

Fontosnak tartjuk hangsúlyozni, hogy kutatásunkban a tényleges informális ellátást vizsgáltuk és nem az informális ellátás iránti igényt. Meglehet, hogy több betegnek lett volna szüksége erre a gondozásra, mint ahányan részesültek benne. Az informális ellátásban nem részesülők között több volt az egyedül élő beteg, elképzelhető, hogy egy részük emiatt nem kapott ilyenfajta gondozást. (9. Táblázat)

Az informális ellátást kapó betegek általános egészségi állapota (EQ-5D-3L) jelentősen rosszabb volt, mint azoké, akik nem kaptak. (9. Táblázat) Az EQ-5D-3L kérdőív dimenziói közül a legnagyobb különbséget az Szokásos tevékenységek és az Önellátás dimenziókban találtuk a két alcsoport között, az informális ellátásban részesülők közül jóval többen jeleztek némi vagy súlyos problémát ezeken a területeken. (12. Ábra) Regresszió elemzésünk megerősítette a feltevésünket, az informális ellátás ideje és az EQ-5D eredmények között szignifikáns kapcsolatot találtunk. (10. Táblázat) Jelentős meghatározó tényezőnek bizonyult továbbá a beteg neme, és a vizsgált 14 kórkép közül oszteoporózisban és Parkinson betegségben volt szignifikáns a kapcsolat. Napi 8 órás gondozási idő limitet alkalmazva hasonló eredményre jutottunk. Ezeket javasolt 
figyelembe venni, ha az informális ellátásra az EQ-5D-3L eredményekből végeznek becslést. Az elemzésbe bevont változók azonban csak kis részben magyarázzák az informális ellátás óraszámot. (10. Táblázat) Nagyobb mintán végzett vizsgálatok javasoltak és további befolyásoló tényezők feltárása (pl. részletesebb szocio-demográfiai jellemzők, a gondozó egészségi állapota és gondozással kapcsolatos életminősége, a gondozó és gondozott közötti viszony) érdekes jövőbeli kutatási területek.

Bár a nemzetközi szakirodalomban számos betegségköltség vizsgálatban közöltek informális ellátás óraszámot és a beteg állapotára vonatkozó EQ-5D adatokat, a kettő kapcsolatát elemző publikáció kevés. Brouwer és munkatársai RA-ban vizsgálták a beteg életminősége, a gondozó munkaképessége és az informális ellátás viszonyát Hollandiában (Brouwer et al., 2004). Svédországban demenciában folytattak hasonló vizsgálatokat (Neubauer et al., 2008, Wimo et al., 2012). A legnagyobb esetszámú kutatást, ismereteink szerint, Németországban végezték Rowen és mtsai (Rowen et al., 2016). Egy 44500 fős kérdőíves vizsgálatból nyert adatok elemzése során azt találták, hogy a 0,1 pontos egészségi állapot javulás az EQ-5D index-szel mérve, modellezési módszertől függően, hat hetes időtávon kevesebb, mint 1 vagy akár több mint 2 nappal csökkentheti azon napok számát, amikor a beteg informális ellátást kap. A beteg állapotának javításával a gondozóknál elérhető időnyereség tehát jelentős, érdemes további hazai kutatásokat végezni ezen a területen és egyidejüleg vizsgálni a gondozók életminőségében bekövetkező változásokat.

Említést kell tenni kutatásunk korlátairól is. Csak azokat a hazai vizsgálatokat vontuk be az elemzésünkbe, ahol betegszintü adatok álltak rendelkezésre, bár ismereteink szerint más hazai kutatócsoportok nem közöltek informális ellátás és EQ-5D-3L adatokat egyaránt tartalmazó felméréseket. Informális ellátás szempontjából fontos klinikai területeket adathiány miatt nem vizsgáltunk - ilyen például az onkológia, életvégi állapotok, időskori diabetes, nagyothallás, COPD, érszükület, artrózis -, javasolt a jövőben ezekben a betegségekben is felméréseket végezni. Az EQ-5D kérdőív öt válaszlehetőséget adó, jobb szenzitivitású verziójával (EQ-5D-5L) végzett felmérések pontosabb képet adhatnak az informális ellátás és az egészségi állapot közötti kapcsolatról (Angelis et al., 2016b, Lopez-Bastida et al., 2016a, Lopez-Bastida et al., 
2016b, Kuhlmann et al., 2016, Cavazza et al., 2016b, Péntek et al., 2014, Péntek et al., 2016a, Rencz et al., 2014, Cavazza et al., 2016a). Egy-egy betegségben érdemes lenne nagyobb mintákon tovább vizsgálni a betegek várakozásait, a betegség stádiumok és az informális ellátás viszonyát, standard betegség-specifikus mércék bevonásával (Herédi et al., 2014, Rencz et al., 2015a). Kutatásunkban nem vizsgáltuk a formális gondozáshoz (egészségügyi és szociális ellátások, bentlakásos otthonok, nappali gondozási központok) való hozzáférést és igénybevételt, ami szintén befolyásolja a családra háruló gondozási terheket.

Úgy gondoljuk, hogy ezen korlátok ellenére kutatásunk értékes összefoglalást és elemzést ad a krónikus betegségek széles körében az informális ellátásról és annak meghatározó tényezőiről Magyarországon. Eredményeink alapján a családra háruló terhek, különösen a korlátozottsághoz vezető betegségek esetében, igen jelentősek. A gyógyítás során a beteg családtagjai életében bekövetkezett változásokat - beleértve a gondozók életminőségét és az informális ellátással összefüggő költségeket - érdemes és szükséges felmérni ahhoz, hogy valós képet kapjunk a betegség okozta terhekröl, illetve sikeres kezelés esetén az elért eredményekről.

Közpolitikai jelentőség

Kutatásunk alapadatokkal szolgál további egészség-gazdaságtani elemzésekhez, valamint rávilágít az informális ellátással kapcsolatos kutatások fontosságára, módszertani kihívásaira és még fel nem tárt, jelentős kutatási területekre. Közpolitikai szempontból, az egyes egészségügyi problémák betegség terhe társadalmi szempontból vizsgálandó. Valamennyi olyan tényezőt fel kell tárnunk és mérnünk kell, amely hozzájárul a társadalmi teherhez és ebből a szempontból lényeges lehet. Tipikusan ilyen, a formális, szükebb, finanszírozói nézőpontból figyelmen kívül hagyott informális ellátás, amely jelentős társadalmi teher.

Bízunk benne, hogy elemzésünk lendületet ad a hazai informális ellátással kapcsolatos vizsgálatoknak, ezáltal hatékonyabbá és sikeresebbé válhat a betegellátás. 


\subsection{Költségszámítás}

\subsubsection{Az informális ellátás költsége krónikus betegségekben: magyarországi kutatások összehasonlító elemzés}

Az informális ellátás költsége a nemzetközi adatokhoz hasonlóan hazánkban is igen magas, ezt vizsgálatunk eredményei egyértelmüen igazolják. A jelen tanulmányban felhasznált kutatások során olyan betegek kerültek bevonásra, akik betegségük miatt járóbetegellátást illetve kórházi kezelést vettek igénybe, és a betegminták ezeknek a betegeknek a csoportját reprezentálják.

Az informális ellátás pontos összegének kalkulálásához azonban tudnunk kellene azt, hogy az általunk vizsgált megbetegedések esetén vizsgálati eredményeink milyen mértékben általánosíthatók a megbetegedésben szenvedők teljes populációjára. Ezt nem ismerjük, ezeket az információkat a rutinszerüen gyüjtött adatok adatbázisai sem tartalmazzák (NEAK, korábban OEP és más népegészségügyi adatbázisok), erre pedig szükségünk lenne az összegek megbízható kalkulálásához (KSH, 2009, OECD, 2017). Lakossági adatok vannak különböző felmérésekből arra vonatkozóan, hányan nyújtanak, illetve kapnak informális ellátást az idősebb korosztályban Magyarországon. Ezek azonban nem tartalmaznak konkrét diagnózisokhoz, illetve egészségi állapotokhoz köthető adatokat, így nem alkalmasak a különböző betegségek okozta betegségteher becslésére az egészséggazdaságtani elemzések során.

Az informális ellátás költségének mérése nemzetközi tanulmányokban is megjelenik. Krol és munkatársai szisztematikus irodalom-áttekintésében szintén megjelent a reumatoid artritisz is. A szerzők a reumatoid artritisz betegek esetében felmerülő informális ellátás estében széles tartományt lefedő költségekre vonatkozó eredményeket találtak (569 - 181,620 euró) (Krol et al., 2015).

Ezeknek az összegeknek az ismerete szükséges ahhoz, hogy az egészségpolitika fel tudja mérni a megbetegedések valós társadalmi költségét és fontosságát. Az informális ellátás költségeinek ismerete nélkül nem lehetséges megalapozott egészségpolitikai és finanszírozási döntéseket hozni. A lakosság, a betegek informális ellátás iránti igényét a felmérések egyértelműen mutatják. A várható élettartam növekedése és az egyre nagyobb 
számú krónikus beteg ellátása jól előrejelezhetően növeli az informális ellátás iránti igényt. Az azonos háztartásban élők száma azonban már napjainkban sem magas és várhatóan csökkenni fog, emiatt várhatóan csökkenni fog az informális ellátók száma. Ugyanezt eredményezi az is, hogy ha hazánkban növekszik az aktív munkavállalók száma. Ezeknek a változásoknak az együttes hatására azt eredményezi, hogy az informális ellátás hiányában az állami vagy magán, azaz a formális egészségügynek kell biztosítania ezt az ellátást, amely jelentős kapacitás, munkaerő és költség többlet igényt vetít előre. Meg kell említeni, hogy az egészségügyben és a szociális szférában jelenleg is igen jelentős a szakember hiány, további, nagyobb számú szakember bevonása nem tünik lehetségesnek.

A továbbiakban célszerü lenne pontosan megismerni az informális ellátás iránti igényt hazánkban annak érdekében, hogy az ellátás és a finanszírozási igény ismert és tervezhető legyen, akár az állam, akár a biztosítók számára. Továbbá célszerü lenne pontosan megismerni nem csak az informális ellátás iránti igényeket, hanem a nem megvalósuló igényeket is, és ezzel azonosítani a megfelelő ellátáshoz nem jutó, legveszélyeztetettebb betegeket magában foglaló csoportokat.

Az elemzés korlátai között meg kell említenünk, hogy az országos becslés annak feltételezésével készült, hogy a kutatásba bevont betegek jól reprezentálják a hazánkban található összes beteget, akik a vizsgált betegségben szenvednek. A vizsgálatok során nem vettük figyelembe, hogy egy betegnek többféle krónikus megbetegedése is lehet, emiatt a költséget felülbecsülhettük. A torzítás mértéke további kutatások nélkül megbecsülhetetlenek. További lehetséges torzító tényező az is, hogy csak a konkrét igénybe vett informális ellátást mértük fel, azoknak a betegeknek az esetén, akik informális ellátást igényeltek volna, de erre valamilyen ok miatt nem volt mód, nem tudunk informális költséget kimutatni. Emiatt a tényleges költségeket alulbecsülhettük. További kutatások nélkül erre sem tudunk becslést tenni. További limitációként fontos megemlíteni, hogy a különböző években készült felmérésekben megjelenő óraszámokat 2017-es költségekkel számolva vettük figyelembe. Az eltelt időszakban azonban számos betegség kezelése jelentősen változhatott, az új eredményes terápiák bevezetése módosíthatta az informális ellátás óraszámát egyes beteg alcsoportokban (például: a reumatoid artritiszben szenvedő immár biológiai gyógyszerekkel kezelt betegek). 
Közpolitikai jelentőség

A konkrét költségek ismerete nélkül nem hozható megfelelő közpolitikai döntés.

Eredményeink alapján úgy véljük, hogy a becsült költségek nagyságrendileg megfelelők és hazánkban is jelentős az informális ellátás költsége, amelynek ismerete szükséges a valós társadalmi teher megismeréséhez, a megfelelő egészségpolitikai döntések meghozatalához és a fenntartható finanszírozás kialakításához.

\subsubsection{Betegségköltség vizsgálatok áttekintése kilenc Közép-Kelet-Európai országban}

Irodalomkeresésünk eredményeképpen 58 (83 országspecifikus eredmény tartalmazó) kutatást azonosítottunk, amelyek Ausztria, Bulgária, Csehország, Horvátország, Magyarország, Lengyelország, Románia, Szlovákia, Szlovénia esetében közöltek betegségköltség (COI) adatokat. leggyakrabban tárgyalt klinikai terület az endokrin, táplálkozási és anyagcsere betegségek volt. A költségek euróban való közlése volt a domináns, amely arra utalhat a régió kutatói fontosnak találják eredményeik nemzetközi összehasonlításhoz elérhetővé tenni.

A transzferabilitás kérdése sok esetben felmerül, azonban az 58 vizsgált kutatásban felfedezhető módszertani heterogeneitás ezt jelentősen megnehezítheti a Kelet-KözépEurópai régióban. A közlemények minőségét értékelendő megvizsgáltuk a használt módszertan leírását. Fontosnak tartjuk kiemelni, hogy az erőforrás-felhasználás adatforrásai és a költségszámítás éve szinte minden publikációban közlésre került (rendre 98\% és 95\%), sok más rendkívül fontos indikátor ennél sokkal kevesebb esetben került jelentésre.

A használt perspektíva megjelölése a publikációk 78\%-ában, az indirekt költségek mérésére használt megközelítés 77\%, a költségszámítás módszertana 64\%, legalább egy egységköltség 42\%, az informális ellátás értékelésének módszere 31\% esetében szerepelt. Egy, a közelmúltban Ausztriában folytatott elemzéseket áttekintő review azt találta, hogy a perspekítva és a költségszámítás éve nem került jelentésre a kutatások $60 \%$ és $25 \%$ ában (Mayer et al., 2017). Az eltéréseket a „szürke irodalmak” beválogatása 
magyarázhatja. Mayer és munkatársai 93 gazdasági elemzést tárgyalt, amelyből 14 volt betegségköltség felmérés. Továbbá a 93 kutatásból 23 nem-indexált és 12 nem peerreviewed közlemény volt (Mayer et al., 2017).

Az egy betegséget tárgyaló, eltérő kutatások nagy országonkénti eltéréseket mutattak, azonban az összehasonlíthatóság kutatásonként változó. A használt módszertanok sok esetben nagyon eltérőek voltak, és a kutatásokban szereplő minták eltérései (mintanagyság, mintában szereplők átlagéletkora, diagnózis, rendelkezésre álló terápiák) is sok esetben figyelembe veendőek. Az egységköltségekben megfigyelhető eltérések is nagymértékben hozzájárulhatnak az eredmények eltéréseihez.

A húgyhólyagrák kutatásában például egy kórházi nap költsége 7-szer olyan magas volt Ausztriában (495 euró), mint Romániában (67 euró) (Leal et al., 2016). Olyan módszertani eltérések, mint az incidencián vs. a prevalencián alapuló kutatási módszertan szintén akadályozza a költségek összehasonlítását. Ahogyan az incidencián alapuló, prosztatarákot vizsgáló Brodszky és munkatársai cikk sem hasonlítható össze a prevalancián alapuló Inotai és munkatársai (szintén prosztatarákot is tárgyaló) cikkel, annak ellenére, hogy mindkettő Magyarországról származik (Brodszky et al., 2017, Inotai et al., 2015). Az eltérő egészségügyi rendszerek sajátosságai miatt is nagyon eltérő költségekre vonatkozó eredményeket figyelhetünk meg az eltérő országokban.

Az elmúlt két évtized során számos publikáció jelent meg a transzferabilitásról (Nixon et al., 2009, de Pouvourville et al., 2005, Drummond et al., 2003, Barbieri et al., 2010, Mandrik et al., 2015, Gulácsi et al., 2014a). Jelenleg az egészséggazdaságtani és HTA irányelvek a Közép-Kelet-Európai régióban vagy nagyon limitáltan vagy egyáltalán nem tartalmaznak irányelvet a transzferabilitásra és adaptációkra vonatkozóan. Ezért egy betegségköltség vizsgálatok folytatására vonatkozó irányelv kialakítása rendkívül értékes lenne a régió országai számára (Gulácsi et al., 2014a).

Jelen kutatásunk számos limitációval rendelkezik. Szisztematikus irodalomkeresést folytattunk a releváns publikációk azonosítása érdekében, azonban felmerül a lehetőség, hogy releváns irodalmak nem kerültek azonosításra és beválogatásra. Egyes betegségköltség eredmények esetlegesen nem jelennek meg a reviewunkban, mert keresésünkből kizártuk a konferencia absztraktokat és jelentéseket. Kézi keresést a nemindexált folyóiratokban csak három országban végeztünk. További limitáció, hogy nem alkalmaztunk egy átfogó checklist-et, hiszen tudomásunk szerint ez nem volt elérhető a 
betegségköltségek felmérésekre vonatkozóan, angol vagy magyar nyelven. Ez torzíthatja a tanulmányok minőségével kapcsolatos következtetéseinket, de vélekedésünk szerint, hogy a bemutatott vizsgálati jellemzők jó átfogó leírást adhatnak a beválogatott közleményekről

\section{Közpolitikai jelentőség}

Az eltérő egészségügyi rendszerek sajátosságai miatt is nagyon eltérő költségekre vonatkozó eredményeket figyelhetünk meg a különböző országokban. A finanszírozási döntések meghozatalához szükséges az adott ország sajátosságainak megfelelően végezni az elemzéseket. A transzferálhatóság limitáltsága (a költség adatok nem vihetők át egyik országból a másik országba) és a jogszabályi előírások is a helyi adatok használatának szükségére utalnak.

\subsubsection{A Magyarországi egészségügyi online költség katalógus}

A magyarországi egészség-gazdaságtani publikációkra vonatkozó irodalmi áttekintést készítettünk és végeztük el az ezekben közölt egységköltségek azonosítását. A Magyarországi egészségügyi online költség katalógus kialakításának igénye már korábban is számos esetben felmerült, a 2004-es EU csatlakozás óta, hiszen a helyi adatok használata kiemelten fontos minden egészséggazdaságtani elemzésben.

A bécsi 'cost-library' létrehozásának a szakmai leírását Mayer és munkatársai publikálták. A bécsi kollégák a „,ost-library”-ba kerülő költség elemeket publikált források elemzése során azonosították. Mayer és munkatársai szisztematikus irodalomkeresésükben (2004-2015 időszakot lefedő) a német és angol nyelvü publikációkban összesen 93 publikációt válogattak be, melynek 87\%-a folyóiratcikk volt; klinikai terület szerint a „A keringési rendszer betegségei” ICD fócsoport betegségei jelentek meg leggyakrabban $(n=15)$. A beválogatott cikkek közül 14 darab volt cost of illness analysis. A munka nehézségeit (és egyben fontosságát is) mutatja, hogy Mayer és munkatársai kiemelik, hogy a cikkek 60\%-a nem írta le egyértelműen a kutatás perspektíváját, több, mint negyede nem jelölte meg az összes forrást, valamint a publikációk közel 40\% nem közölt minden releváns egységköltséget (Mayer et al., 2017). 
Irodalomkeresést folyattunk a Magyarországra vonatkozó egységköltségek azonosítása és összegyüjtése érdekében

Keresésünk jelenleg csak Magyarországon publikált közleményekre vonatkozott. A továbbiakban esetleg célszerü az adatainkat a Kelet-Közép-Európai országok hasonló adataival bővíteni. Ebben az esetben feltételezésünk az, hogy a hasonló társadalmi, gazdasági adottságú országok egészségügyi költség adatai közelebb vannak egymáshoz és jobban hasznosíthatók, mint ebből a szempontból egymástól távolabb levő országoké. Közpolitikai jelentőség

Az egészségügyi rendszerekre vonatkozó döntéshozatalok egyik legjelentősebb eleme a forrásallokáció optimalizálása. Ehhez azonban szükséges ismerni az egyes betegségek és az azok kezelésére alkalmazott költségeket. 


\section{8. ÚJ EREDMÉNYEK}

\section{1.Életminőség mérés}

8.1.1. Az európai, lengyel, szlovén és UK EQ-5D-3L értékkészlet összehasonlítása 18 krónikus betegségben

Módszertanon alapuló eltérések fedezhetőek fel az értékkészletek között. Az értékkészletválasztás egyes állapotok hasznosságára gyakorolt hatása jelentős, ezáltal az egészségpolitikában és finanszírozási döntések során felállított prioritásokra hatást gyakorolhat. Ezeket a hatásokat elsőként mutattuk ki és publikáltuk régiónkban, ilyen sok különböző betegség és minta elemszámon alapuló vizsgálat sem lelhető fel az irodalomban.

\subsubsection{A DLQI kérdő́v „,nem releváns” válaszainak részletes elemzése}

Elsőként mutattuk ki és közöltük a szakirodalomban, hogy a DLQI kérdőív „nem releváns" válaszainak részletes elemzése azt mutatja, hogy a nem releváns válaszok előfordulása gyakori. Az idősebb, alacsonyabb iskolázottságú és női betegek körében nagyobb valószínűséggel fordulnak elő, ezért a DLQI pontozás sajátosságai miatt ezek a betegek hátrányos helyzetbe kerülhetnek.

\subsubsection{A magyarországi lakosság egészségi állapota és munkaképessége}

Elsőként számoltunk lakossági értékeket az ICECAP-A és az ICECAP-O mércékkel Magyarországon és a Közép-Kelet-Európai régióban, az EQ-5D-5L és a WPAI kérdőívek használata mellett. Eredményeink, amelyeket régiónkban elsőként közöltünk, a nemzetközi szakirodalomban is a legújabb eredmények közé tartoznak. 


\subsubsection{Informális ellátás és meghatározó tényezői krónikus betegségekben:}

magyarországi kutatások összehasonlító elemzése

Hazánkban és a régióban először mértük fel és publikáltuk az informális ellátás igénybevételét és ennek kapcsolatát az életminőséggel 14 krónikus betegségben, ezekkel az alapadatokkal szolgálhatunk további egészség-gazdaságtani elemzésekhez.

\subsection{Költségszámítás}

\subsubsection{Az informális ellátás költsége krónikus betegségekben: magyarországi kutatások összehasonlító elemzése}

Hazánkban először elemeztük és publikáltuk nagy esetszám alapján, 13 krónikus betegségben az informális ellátás költségeit, és azt találtuk, hogy ez a nemzetközi adatokhoz hasonlóan hazánkban is jelentős mértékűek.

\subsubsection{Betegségköltség vizsgálatok áttekintése kilenc Közép-Kelet- Európai országban}

Először elemeztünk és publikáltunk a Közép és Kelet Európai régióban több országra (kilenc) kiterjedő, betegség-költség vizsgálatok összehasonlítását tartalmazó vizsgálati eredményeket. Elemzésünk eredményei azt mutatják, hogy nem valós az az általánosan elfogadott vélemény, hogy a régió országainak betegségteher eredményei jól transzferálhatók országok között. Ennek oka a nagyfokú módszertani heterogenitás és a közlési standardok hiánya.

\subsubsection{Magyarországi egészségügyi online költség katalógus}

Európában negyedikként, a helyi adatok használatának igénye okán, a releváns publikációk azonosítása segítségével elvégeztük a Magyarországra vonatkozó egységköltségeket összesítő adatbázis kialakítását. 


\section{9. ÖSSZEFOGLALÁS}

A dolgozatban a betegség költség és az életminőség szerepét kívántam megvizsgálni a forrásallokációs döntések során az egészségügyben, amely egy kiemelten fontos kérdés, hiszen a krónikus megbetegedések betegségterhe, költségei nem csak egyéni, hanem társadalmi szinten is jelentős és folyamatosan egyre növekvő mértéküek.

A krónikus betegségek közgazdaságtana egészségpolitikai, népegészségügyi forrásallokációs, és finanszírozási szempontból kiemelten fontos kérdés, hiszen a fenntartható finanszírozás és az ehhez szükséges optimális forrásallokáció megteremtéséhez szükséges a költségek és az outcome-ok (eredmények, kimenetek) ismerete. A betegségteher felmérése továbbá a terápiák költség-hatékonyságának elemzése szempontjából is nélkülözhetetlen információkat jelent a finanszírozó és egészségpolitikai döntéshozó számára.

A dolgozatban tárgyalt kutatási területek és a kutatásokban szereplő adatok ezért feltétlenül szükségesek a finanszírozási döntések előkészítése, a forrásallokáció optimális megszervezése érdekében.

A megbetegedések során felmerülő egyes költségekről sok esetben nincs elegendő információnk, ilyen például a hozzátartozók által nyújtott informális ellátás költsége vagy a munkatermelékenység csökkenés miatt felmerülő költségek. Fontos kiemelni, hogy ezekre vonatkozóan nem találunk adatot a rutinszerűen gyüjtött adatbázisokban, ezért a költségük és ezáltal a megbetegedések kapcsán felmerülő teljes társadalmi teher nem ismert.

További fontos tényező a megbetegedések kapcsán az életminőség. Az életminőségre és az életminőség társadalmi vetületére vonatkozó adatok sem kerülnek gyüjtésre rutinszerüen létrehozott adatbázisokban, ezáltal felmerül a probléma, hogy nem tudjuk teljeskörüen mérni a terápiák eredményeit, hiszen a terápiák sok esetben nem csupán a klinikai tünetek megszüntetését, hanem az életminőség javítását és a képességek helyreállítását célozzák meg. Mindezekre vonatkozó adatok csak ilyen jellegü kutatásokból tudhatók meg. 
Jelen dolgozatban az életminőség mérés és a költségszámítás területét lefedő kutatásokat tárgyaltunk: Az életminőség kérdésének vizsgálata során az általános EQ-5D és egy betegségspecifikus kérdőív sajátosságait vizsgáltuk, valamint kitértünk a magyar lakosság esetében az életminőség, a társadalmi képességek és hiányuk, valamint a munkatermelékenység veszteség kérdését vizsgáltuk. A dolgozatban külön figyelmet fordítottunk az informális ellátás igénybevételének és költségeinek vizsgálatára, és azt találtuk, hogy ezek Magyarországon is rendkívül jelentősek.

A betegségek költségeinek vizsgálata érdekében a dolgozatban bemutatásra került a betegségköltség vizsgálatok áttekintése a régióban, azaz kilenc Közép-Kelet-Európai országban. Ennek eredményei alapján arra tudunk következtetni, hogy a régió országban publikált költség adatok hazai felhasználhatósága és transzferálhatósága erősen limitált, a publikációkban nagy módszertani heterogenitással találkoztunk.

A Magyarországi egészségügyi online költség katalógus szintén jelentős szereppel bír a betegségek költségeinek megismerése és az egészségügy finanszírozásának szempontjából. Hazánkban a költségadatok jelenleg szinte kizárólagos forrása a Nemzeti Egészségbiztosítási Alapkezelő (NEAK korábban: OEP) adatbázisai, amelyek nagyon sok olyan adatot nem tartalmaznak, amely az egészségügyi közgazdaságtani vizsgálatok szempontjából nélkülözhetetlenek (például: direkt nem-egészségügyi költségek, indirekt költségek, betegségek súlyosságára vonatkozó outcome adatokat és a különböző beavatkozások eredményét). Emiatt a költségek szélesebb körét tartalmazó Magyarországi egészségügyi online költség katalógusra igen nagy szükség van. A dolgozatban megjelent a Magyarországi egészségügyi online költség katalógus kialakításának menete: irodalomkeresést folytattunk a releváns publikációk azonosítása érdekében. Keresésünk eredményeként 75 beválogatott publikációt használva alakítottuk ki a Magyarországi egészségügyi online költség katalógus szerkezetét és vizsgáltuk meg a közlemények jellemzőit.

A publikációkban található egészségügyi közgazdaságtani eredmények egészségpolitikai döntéselökészítési célú felhasználását a következők jelentősen megnehezíti, hogy a publikációkban használt módszertan rendkívül heterogén, nem minden esetben teljeskörüen leírt, az adatok forrása sok esetben nem egyértelmüén azonosítható és a valós költségek nem feltétlenül esnek egybe a finanszírozási összegekkel. 


\section{HIPOTÉZISEKRE ADOTT VÁLASZOK}

\section{1. Életminőség mérés}

Az európai, lengyel, szlovén és UK EQ-5D-3L értékkészlet összehasonlitása 18 krónikus betegségben

1.Hipotézis

Feltételezzük, hogy az európai, lengyel, szlovén és UK EQ-5D-3L értékkészlet nem tér el egymástól lényegesen.

A kutatás eredménye azt mutatja, hogy az értékkészletek jelentősen eltérnek, ennek megfelelöen az 1. Hipotézist elvetjük.

Alhipotézis:

1.1.: Feltételezzük, hogy a különbözö értékkészleteket alkalmazzuk a vizsgált 18 krónikus betegségben, akkor az eredmények alapján kialakított egészségpolitikai és finanszírozási döntések nem térnek el egymástól lényegesen a különböző országokban.

A kutatási eredményeink azt mutatják, hogy az eltérö értékkészletek következtében az egészségpolitikai és finanszírozási döntések eltérhetnek egymástól, ezért a 1.1. Alhipotézist elvetjük.

A DLQI kérdöív „, nem releváns” válaszainak részletes elemzése

\section{Hipotézis}

Feltételezzük, hogy a DLQI kérdőív esetében a nem releváns válaszainak az elemzése különbségeket fog mutatni a különböző demográfiai és társadalmi-gazdasági jellemzőkel rendelkező csoportok között.

Kutatási eredményeink azt mutatják, hogy különbözö demográfiai és társadalmigazdasági jellemzökel rendelkezö csoportok között jelentös különbségek lehetnek a nem releváns kérdések miatt, ennek megfelelöen a 2. Hipotézist elfogadjuk. 
Alhipotézis:

2.1. Feltételezzük, hogy a különbségek orvosi döntéshozatalra, forrásallokációra gyakorolt hatása észlelhető.

Kutatásunk eredményei azt mutatják, hogy az eltérések az orvosi döntéshozatalra, forrás allokációra gyakorolt hatása jelentős lehet, ezért a 2.1Hipotézist elfogadjuk.

A magyarországi lakosság egészségi állapota és munkaképessége

\section{Hipotézis}

Feltételezzük, hogy a magyarországi lakosság egészségi állapota és munkaképessége az általunk alkalmazott mércékkel megfelelően jellemezhető.

A magyarországi lakosság egészségi állapota és munkaképessége az általunk alkalmazott mércékkel megfelelöen jellemezhetö, ennek megfelelöen a 3. Hipotézist elfogadjuk.

Informális ellátás és meghatározó tényezői krónikus betegségekben: magyarországi kutatások összehasonlító elemzése

\section{Hipotézis}

Feltételezzük, hogy az informális ellátás jellemzői és meghatározó tényezői, hazánkban hasonlóak más országokéhoz.

Kutatási eredményeink azt mutatják, hogy az informális ellátás jellemzői és meghatározó tényezői, hazánkban hasonló más országokéhoz hasonlók, ennek megfelelöen a 4. Hipotézist elfogadjuk. 


\subsection{Költségszámítás}

Az informális ellátás költsége krónikus betegségekben: magyarországi kutatások összehasonlitó elemzés

5. Hipotézis

Feltételezzük, hogy az informális ellátás társadalmi terhe, költsége, hazánkban is a nemzetközi tapasztalatoknak megfelelően igen jelentős.

Kutatási eredményeink azt mutatják, hogy az informális ellátás társadalmi terhe, költsége, hazánkban is a nemzetközi tapasztalatoknak megfelelöen igen jelentös. Hazánkban ez a teher abszolút értékben alacsonyabb, mint a magasabb GDP/fö országokban, de arányaiban hasonló, ennek megfelelöen az 5. Hipotézist elfogadjuk.

Betegségköltség vizsgálatok áttekintése kilenc Közép-Kelet-Európai országban

6.Hipotézis

Feltételezzük, hogy a betegség költségek hazánkban hasonlatosak más Közép-KeletEurópai országokéhoz.

Kutatási eredményeink azt mutatják, hogy a betegség költségek hazánkban hasonlatosak más Közép-Kelet-Európai országokéhoz ezért a 6. Hipotézist elfogadjuk.

Alhipotézis:

6.1. Feltételezzük, hogy hazánkban a Közép-Kelet-Európai országban publikált költség adatok jobban felhasználhatóak és transzferálhatóak, mint a magas nemzeti jövedelemmel rendelkező országok költség adatai.

Kutatásunk eredményei azt mutatják, hogy a Közép-Kelet-Európai országban publikált költség adatok hazai felhasználhatósága és transzferálhatósága erösen limitált, feltételezzük, hogy más országok (pl. UK) eredményei jobban trnaszferálhatók, ennek megfelelöen a 6.1 hipotézist elvetjük. 
A Magyarországi egészségügyi online költség katalógus

\section{Hipotézis}

Feltételezzük, hogy a Magyarországi egészségügyi online költség katalógus létrehozásához rendelkezünk elegendö hazai adattal és a Magyarországi egészségügyi online költség katalógus létrehozható.

Kutatásunk eredménye azt mutatja, hogy a Magyarországi egészségügyi online költség katalógus létrehozásához rendelkezünk elegendö hazai adattal és a Magyarországi egészségügyi online költség katalógus létrehozható, ezért a 7. Hipotézist elfogadjuk.

Alhipotézisek:

7.1. Feltételezzük, hogy a Magyarországi egészségügyi online költség katalógus hozzájárulhat a megfelelö és fenntartható egészségügyi finanszírozási döntések kialakításához.

A jelenleg folyó egészségügyi reform nevesített adatszükségletei azt mutatják, hogy ilyen adatokra napjainkban nagyobb szükség van, mint eddig bármikor, a 7.1. Hipotézist elfogadjuk.

7.2. Feltételezzük, hogy a hazai egységköltségek és költségek jelentősen eltérnek a magas jövedelemmel rendelkező országokétól.

Kutatási eredményeink azt mutatják, hogy a hazai egységköltségek és költségek jelentösen eltérnek a magas jövedelemmel rendelkezö országokétól. a 7.2. Hipotézist elfogadjuk. 


\section{A DOLGOZAT MEGÍRÁSÁHOZ FELHASZNÁLT SAJÁT PUBLIKÁCIÓK LISTÁJA}

Zrubka Zs, Beretzky Zs, Hermann Z, Brodszky V, Gulácsi, L, Rencz, F, Baji P, Golicki D, Prevolnik-Rupel V, Péntek M (2019): A comparison of European, Polish, Slovenian and British EQ-5D-3L value sets using a Hungarian sample of 18 chronic diseases. European Journal of Health Economics 20, Suppl. 1, pp. 119-132. doi: 10.1007/s10198019-01069-8.

Brodszky V, Beretzky Zs, Baji P, Rencz F, Péntek M, Rotar A, Tachkov K, Mayer S, Simon J, Niewada M, Hren R, Gulácsi L (2019): Cost-of-illness studies in nine Central and Eastern European countries. In: European Journal of Health Economics, 20, Suppl1, pp. 155-172. doi: 10.1007/s10198-019-01066-x.

Rencz F, Poór AK, Péntek M, Holló P, Kárpáti S, Gulácsi L, Szegedi A, Reményik É, Hidvégi B, Herszényi K, Jókai H, Beretzky Zs, Brodszky V (2018): A detailed analysis of 'not relevant' responses on the DLQI in psoriasis: potential biases in treatment decisions. Journal of The European Academy of Dermatology and Venereology, 32, 5, pp. 783-790. doi: 10.1111/jdv.14676.

Beretzky Zs, Péntek M (2017): Informális ellátás és meghatározó tényezői krónikus betegségekben: magyarországi kutatások összehasonlító elemzése [Characteristics and determinants of informal care in chronic diseases in Hungary: a comparative analysis]. Orvosi Hetilap, 158, 52, pp. 2068-2078. doi: 10.1556/650.2017.30894.

Beretzky Zs: Az informális ellátás költsége krónikus betegségekben: magyarországi kutatások összehasonlító elemzése. Köz-Gazdaság, publikálációra elfogadott

Péntek M, Beretzky Zs, Brodszky V, Szabó, A. Kovács, L. Kincses, Á. Baji P, Zrubka Zs, Rencz F, Gulácsi L: A magyarországi lakosság egészséggel összefüggő munkaképessége: keresztmetszeti reprezentatív felmérés a Munkaképességre és Tevékenységcsökkenésre vonatkozó kérdőívvel. Orvosi Hetilap, publikációra elfogadott 


\section{FELHASZNÁLT IRODALOM}

AEEK. 2019a. Állami Egészségügyi Ellátó Központ - Egészségügyi Rendszerek Adattára. Elérhető: https://era.aeek.hu/, Utolsó letöltés ideje: 06/07/2019.

AEEK. 2019b. Állami Egészségügyi Ellátó Központ honalpja. Elérhető: https://www.aeek.hu/tematikus-kiadvanyok, Utolsó letöltés ideje: 06/07/2019.

Al-Janabi, H., Flynn, T. N. ,Coast, J. (2012): Development of a self-report measure of capability wellbeing for adults: the ICECAP-A. Quality of Life Research, 21, pp. 167-176. DOI:

Al-Janabi, H., Peters, T. J., Brazier, J., Bryan, S., et al. (2013): An investigation of the construct validity of the ICECAP-A capability measure. Quality of Life Research, 22, pp. 1831-1840. DOI:

Angelis, A., Kanavos, P., Lopez-Bastida, J., Linertova, R., et al. (2016a): Socialeconomic costs and health-related quality of life in patients with epidermolysis bullosa in Europe. Eur J Health Econ, 17 pp. 31-42. DOI: 10.1007/s10198-0160783-4

Angelis, A., Kanavos, P., Lopez-Bastida, J., Linertova, R., et al. (2016b): Socialeconomic costs and health-related quality of life in patients with epidermolysis bullosa in Europe. Eur J Health Econ, 17 Suppl 1, pp. 31-42. DOI: 10.1007/s10198-016-0783-4

Angelis, A., Kanavos, P., Lopez-Bastida, J., Linertova, R., et al. (2016c): Socio-economic costs and health-related quality of life in juvenile idiopathic arthritis: a cost-ofillness study in the United Kingdom. BMC Musculoskelet Disord, 17, pp. 321. DOI: $10.1186 / \mathrm{s} 12891-016-1129-1$

Angelis, A., Tordrup, D. ,Kanavos, P. (2015): Socio-economic burden of rare diseases: A systematic review of cost of illness evidence. Health Policy, 119, pp. 964-79. DOI: 10.1016/j.healthpol.2014.12.016

Arno, P. S., Levine, C. ,Memmott, M. M. (1999): The economic value of informal caregiving. Health Aff (Millwood), 18, pp. 182-8. DOI: 10.1377/hlthaff.18.2.182

Baji, P., Brodszky, V., Rencz, F., Boncz, I., et al. (2015): Health status of the Hungarian population between 2000-2010 [A magyar lakosság egészségi állapota 2000 és 2010 között]. Orv Hetil, 156, pp. 2035-2044. DOI: 10.1556/650.2015.30288

Baji, P., Farkas, M., Beretzky, Z. ,Péntek, M. 2019. Wellbeing of the Hungarian population Experiences of a population survey, population norms, Research report. Corvinus University of Budapest.

Baji, P., Gulacsi, L., Brodszky, V., Vegh, Z., et al. (2018): Cost-effectiveness of biological treatment sequences for fistulising Crohn's disease across Europe. United European Gastroenterol J., 6, pp. 310-321. DOI: 10.1177/2050640617708952.

Baji, P., Pavlova, M., Gulacsi, L. ,Groot, W. (2012a): Changes in equity in out-of-pocket payments during the period of health care reforms: evidence from Hungary. Int $J$ Equity Health, 11, pp. 36. DOI: 10.1186/1475-9276-11-36

Baji, P., Pavlova, M., Gulacsi, L., Zsofia, H. C., et al. (2012b): Informal payments for healthcare services and short-term effects of the introduction of visit fee on these payments in Hungary. Int $J$ Health Plann Manage, 27, pp. 63-79. DOI: 10.1002/hpm.1106 
Balázs, B., Péter, G. ,László, I. (2015): A Homogén Betegségcsoportok és a hozzá kapcsolódó finanszírozási rendszer elmúlt 25 éve. Orvosi Hetilap, 156, pp. 11551164. DOI:

Balogh, O., Brodszky, V., Gulacsi, L., Heredi, E., et al. (2014): Cost-of-illness in patients with moderate to severe psoriasis: a cross-sectional survey in Hungarian dermatological centres. Eur J Health Econ, 15 Suppl 1, pp. S101-9. DOI: 10.1007/s10198-014-0599-z

Balogh, O., Pentek, M., Gulacsi, L., Farkas, K., et al. (2013): [Quality of life and burden of disease in peripheral arterial disease: a study among Hungarian patients]. Orv Hetil, 154, pp. 464-70. DOI: 10.1556/OH.2013.29567

Barbieri, M., Drummond, M., Rutten, F., Cook, J., et al. (2010): What do international pharmacoeconomic guidelines say about economic data transferability? Value Health, 13, pp. 1028-37. DOI: 10.1111/j.1524-4733.2010.00771.x

Bashyam, A. M. ,Feldman, S. R. (2019): Dermatology Life Quality Index: does improving the instrument make it better? Br J Dermatol, 5, pp. 1082-1083. DOI: $10.1111 /$ bjd. 18598

Basra, M. K., Fenech, R., Gatt, R. M., Salek, M. S., et al. (2008): The Dermatology Life Quality Index 1994-2007: a comprehensive review of validation data and clinical results. $\mathrm{Br} J$ Dermatol, 159, pp. 997-1035. DOI: 10.1111/j.13652133.2008.08832.x

Batog, P., Rencz, F., Pentek, M., Gulacsi, L., et al. (2018): EQ-5D studies in cardiovascular diseases in eight Central and Eastern European countries: a systematic review of the literature. Kardiol Pol, 76, pp. 860-870. DOI: 10.5603/KP.a2018.0033

Bauer, U. E., Briss, P. A., Goodman, R. A. ,Bowman, B. A. (2014): Prevention of chronic disease in the 21st century: elimination of the leading preventable causes of premature death and disability in the USA. Lancet, 384, pp. 45-52. DOI: 10.1016/s0140-6736(14)60648-6

Beretzky, Z. Az informális ellátás költsége krónikus betegségekben: magyarországi kutatások összehasonlító elemzése. Köz-Gazdaság. publikációra elfogadott

Beretzky, Z. ,Péntek, M. (2017): Characteristics and determinants of informal care in chronic diseases in Hungary: a comparative analysis [Informális ellátás és meghatározó tényezői krónikus betegségekben: magyarországi kutatások összehasonlító elemzése.]. Orv Hetil, 158, pp. 2068-2078. DOI: 10.1556/650.2017.30894

Bernert, S., Fernandez, A., Haro, J. M., Konig, H. H., et al. (2009): Comparison of different valuation methods for population health status measured by the EQ-5D in three European countries. Value Health, 12, pp. 750-8. DOI: 10.1111/j.15244733.2009.00509.x

Blahova Dusankova, J., Kalincik, T., Dolezal, T., Kobelt, G., et al. (2012): Cost of multiple sclerosis in the Czech Republic: the COMS study. Mult Scler, 18, pp. 662-8. DOI: $10.1177 / 1352458511424422$

Bocskai, T., Loibl, C., Vamos, Z., Woth, G., et al. (2018): Cost-effectiveness of anesthesia maintained with sevoflurane or propofol with and without additional monitoring: a prospective, randomized controlled trial. BMC Anesthesiol., 18, pp. 100. DOI:

Bodnár, R., Mészáros, Á. ,Kádár, L. (2010): Tuberkulózis kezelése során felmerülő direkt költségek elemzése gyermekkorban Acta Pharmaceutica Hungarica, pp. 1-7. DOI: 
Boncz, I., Brodszky, V., Pentek, M., Agoston, I., et al. (2010): The disease burden of colorectal cancer in Hungary. Eur J Health Econ, 10 Suppl 1, pp. S35-40. DOI: 10.1007/s10198-009-0192-z

Boncz, I. ,Sebestyén, A. (2006): Financial deficits in the health services of the UK and Hungary. Lancet, 368, pp. 917-918. DOI: 10.1016/S0140-6736(06)69369-0

Borsos, N. ,Muszbek , N. (2006): A Clopidogrel költség-hatékonysági elemzése STeleváció nélküli Akut Koronária Szindrómában (ACS) Magyarországon. IME Interdiszciplináris Magyar Egészségügy, 5, pp. 36-40.

Bovolenta, T., De Azevedo Silva, S., Arb Saba, R., Borges, V., et al. (2017): Systematic Review and Critical Analysis of Cost Studies Associated with Parkinson's Disease. Parkinsons Dis., DOI: 10.1155/2017/3410946

Brazier, J., Rowen, D., Karimi, M., Peasgood, T., et al. (2018): Experience-based utility and own health state valuation for a health state classification system: why and how to do it. Eur J Health Econ, 19, pp. 881-891. DOI: 10.1007/s10198-0170931-5

Brazier, J. E., Rowen, D., Lloyd, A. ,Karimi, M. (2019): Future Directions in Valuing Benefits for Estimating QALYs: Is Time Up for the EQ-5D? Value Health, 22, pp. 62-68. DOI: 10.1016/j.jval.2018.12.001

Bremer, P., Cabrera, E., Leino-Kilpi, H., Lethin, C., et al. (2015): Informal dementia care: Consequences for caregivers' health and health care use in 8 European countries. Health Policy, 119, pp. 1459-71. DOI: 10.1016/j.healthpol.2015.09.014

Brodszky, N., Péntek, M., Bíro, Z., Kölkedi, Z., et al. (2014a): Időskori macula degenerációval élő betegek klinikai jellemzői és betegségterhei. Szemészet, 151, pp. 59-60. . DOI:

Brodszky, V., Baji, P., Balogh, O. ,Pentek, M. (2014b): Budget impact analysis of biosimilar infliximab (CT-P13) for the treatment of rheumatoid arthritis in six Central and Eastern European countries. Eur J Health Econ, 15 Suppl 1, pp. S6571. DOI: 10.1007/s10198-014-0595-3

Brodszky, V., Balint, P., Geher, P., Hodinka, L., et al. (2009): Disease burden of psoriatic arthritis compared to rheumatoid arthritis, Hungarian experiment. Rheumatol Int, 30, pp. 199-205. DOI: 10.1007/s00296-009-0936-1

Brodszky, V., Beretzky, Z., Baji, P., Rencz, F., et al. (2019): Cost-of-illness studies in nine Central and Eastern European countries. Eur J Health Econ, 20, pp. 155-172. DOI: 10.1007/s10198-019-01066-X

Brodszky, V., Érsek, K., Gulácsi, L., Kárpáti, K., et al. (2010a): A stroncium-ranelát (Protelos) szerepe a postmenopausás osteoporosis terápiájában; szakirodalmi áttekintés és egészség-gazdaságtani vizsgálat. Budapest, Budapesti Corvinus Egyetem Egészség-gazdaságtani és Egészségügyi Technológiaelemzési Kutatóközpont.

Brodszky, V., Érsek, K., Gulácsi, L. ,Péntek, M. (2011a): A tocilizumab (RoActemra $\left.{ }^{\circledR}\right)$ szerepe a rheumatoid arthritis terápiájában; szakirodalmi áttekintés és egészséggazdaságtani vizsgálat. Budapest, Budapesti Corvinus Egyetem Egészséggazdaságtani és Egészségügyi Technológiaelemzési Kutatóközpont.

Brodszky, V., Gulácsi, L., Kárpáti, K. ,Péntek, M. (2010b): A parenteralis methotrexat szerepe a rheumatoid arthritis terápiájában: A szakirodalom áttekintése, keresztmetszeti vizsgálat és egészség-gazdaságtani elemzés. Budapest, Budapesti Corvinus Egyetem Egészség-gazdaságtani és Egészségügyi Technológiaelemzési Kutatóközpont.

Brodszky, V., Gulácsi, L., Péntek, M. ,Baji, P. (2011b): Az Alprestil (alprostadil) szerepe a perifériás artériás obliteratív érbetegségek terápiájában: irodalmi áttekintés és 
egészség-gazdaságtani értékelés Budapest, Budapesti Corvinus Egyetem Egészség-gazdaságtani és Egészségügyi Technológiaelemzési Kutatóközpont.

Brodszky, V., Gulácsi, L., Péntek, M. ,Baji, P. (2011c): A capsaicin 8\%-os (Qutenza) tapasz szerepe a nem diabéteszes, perifériás neuropátiás fájdalom terápiájában: irodalmi áttekintés és egészség-gazdaságtani értékelés. Budapest, Budapesti Corvinus Egyetem Egészség-gazdaságtani és Egészségügyi Technológiaelemzési Kutatóközpont.

Brodszky, V., Orlewska, E., Pentek, M., Karpati, K., et al. (2010c): Challenges in economic evaluation of new drugs: experience with rituximab in Hungary. Med Sci Monit., 16, pp. SR1-5. DOI:

Brodszky, V., Péntek, M., Baji, P. ,Gulacsi, L. (2012): A fidaxomicin (Dificlir) szerepe a Clostridium difficile terápiájában; szisztematikus irodalmi áttekintés és egészséggazdaságtani értékelés. Budapest, Budapesti Corvinus Egyetem Egészséggazdaságtani és Technológiaelemzési Kutatóközpont.

Brodszky, V., Péntek, M., Baji, P. ,Gulacsi, L. (2013): Az Enzalutamide (MD3100) szerepe a prosztatarák terápiájában; szisztematikus irodalmi áttekintés és egészség-gazdaságtani értékelés. Budapest, Budapesti Corvinus Egyetem Egészségügyi Közgazdaságtan Tanszék.

Brodszky, V., Péntek, M., Baji, P., Rencz, F., et al. (2015): A parenterális metotrexát szerepe a Crohn-betegség terápiájában; szisztematikus irodalmi áttekintés és egészség-gazdaságtani értékelés. Budapest, HTA Consulting Budapest.

Brodszky, V., Péntek, M., Bálint, P. V., Geher, P., et al. (2010d): Comparison of the Psoriatic Arthritis Quality of Life (PsAQoL) questionnaire, the functional status (HAQ) and utility (EQ-5D) measures in psoriatic arthritis: results from a crosssectional survey. Scand J Rheumatol, 39, pp. 303-9. DOI: 10.3109/03009740903468982

Brodszky, V., Péntek, M., I., M., Kárpáti, K., et al. (2006a): A rituximab helye a rheumatoid arthritis terápiájában: a szakirodalom szisztematikus áttekintése és egészség-gazdaságtani értékelés. Budpest, Budapesti Corvinus Egyetem Közszolgálati Tanszék Egészségügyi Gazdaságtani és Technológiaelemzési Munkacsoport.

Brodszky, V., Péntek, M., Jelics, N., Érsek, K., et al. (2010e): Inzulinnal kezelt felnőttkorú cukorbetegek egészségügyi költségterhe. Felmérés háziorvosi praxisokban, illetve szakellátóhelyeken gondozott 480 beteg keresztmetszeti vizsgálata alapján. Diabetologia Hungarica, 19, pp. 37-44. DOI:

Brodszky, V., Péntek, M., Májer, I., Kárpáti, K., et al. (2006b): Az etanercept szerepe a Juvenilis Idiopathiás Arthritis terápiájában: az irodalom szisztematikus áttekintése és egészséggazdaságtani értékelés. Budapest, Budapesti Corvinus Egyetem Közszolgálati Tanszék Egészségügyi Gazdaságtani és Technológiaelemzési Munkacsoport.

Brodszky, V., Péntek, M., Májer, I., Kárpáti, K., et al. (2007): Az abatacept szerepe a rheumatoid arthritis terápiájában a szakirodalom szisztematikus áttekintése és egészséggazdaságtani értékelés. Budapest, Budapesti Corvinus Egyetem Közszolgálati Tanszék Egészség-gazdaságtani és Technológiaelemzési Kutatóközpont.

Brodszky, V., Tamási, B., Hajdu, K., Pentek, M., et al. (2020): Disease burden of patients with pemphigus from a societal perspective. Expert Rev Pharmacoecon Outcomes Res, 28, pp. 1-9. DOI: 10.1080/14737167.2020.1722104 
Brodszky, V., Varga, P., Gimesi-Orszagh, J., Fadgyas-Freyler, P., et al. (2017): Longterm costs and survival of prostate cancer: a population-based study. Int Urol Nephrol., 49, pp. 1707-1714. DOI: 10.1007/s11255-017-1669-9.

Brooks, R., Rabin, R. ,De Charro, F. (2003): The Measurement and Valuation of Health Status Using EQ-5D: A European Perspective. Kluwer Academic Publishers.

Brouwer, W., Van Exel, N., Van De Berg, B., Dinant, H., et al. (2004): Burden of caregiving: evidence of objective burden, subjective burden, and quality of life impacts on informal caregivers of patients with rheumatoid arthritis. Arthritis Rheum, 51, pp. 570-577. DOI: 10.1002/art.20528.

Cavazza, M., Kodra, Y., Armeni, P., De Santis, M., et al. (2016a): Social/economic costs and quality of life in patients with haemophilia in Europe. Eur J Health Econ, 17 pp. 53-65. DOI: 10.1007/s10198-016-0782-5

Cavazza, M., Kodra, Y., Armeni, P., De Santis, M., et al. (2016b): Social/economic costs and health-related quality of life in patients with Duchenne muscular dystrophy in Europe. Eur J Health Econ, 17 pp. 19-29. DOI: 10.1007/s10198-016-0782-5

Chevreul, K., Gandre, C., Brigham, K. B., Lopez-Bastida, J., et al. (2016a): Social/economic costs and health-related quality of life in patients with fragile $\mathrm{X}$ syndrome in Europe. Eur J Health Econ, 17 pp. 43-52. DOI: 10.1007/s10198016-0784-3

Chevreul, K., Michel, M., Brigham, K. B., Lopez-Bastida, J., et al. (2016b): Social/economic costs and health-related quality of life in patients with cystic fibrosis in Europe. Eur J Health Econ, 17 pp. 7-18. DOI: 10.1007/s10198-0160781-6

Clemens, S., Begum, N., Harper, C., Whitty, J. A., et al. (2014): A comparison of EQ5D-3L population norms in Queensland, Australia, estimated using utility value sets from Australia, the UK and USA. Qual Life Res, 23, pp. 2375-81. DOI: 10.1007/s11136-014-0676-x

Colijn, J. M., Buitendijk, G. H. S., Prokofyeva, E., Alves, D., et al. (2017): Prevalence of Age-Related Macular Degeneration in Europe: The Past and the Future. Ophthalmology, 124, pp. 1753-1763. DOI: 10.1016/j.ophtha.2017.05.035

Colombo, F., Llena-Nozal, A., Mercier, J. ,Tuadens, F. 2011. Help wanted? Providing and paying for long-term care.: OECD Publishing. Elérhető: http://dx.doi.org/10.1787/9789264097759-en, Utolsó letöltés ideje: 22/04/2017.

Costa, N., Ferlicoq, L., Derumeaux-Burel, H., Rapp, T., et al. (2013): Comparison of informal care time and costs in different age-related dementias: a review. Biomed Res Int., pp 852368. DOI: 10.1155/2013/852368

Coyle, K., Coyle, D., Lester-George, A., West, R., et al. (2018): Development and application of an economic model (EQUIPTMOD) to assess the impact of smoking cessation. Addiction., 113, pp. 7-18. DOI: 10.1111/add.14001.

Czech, M., Opolski, G., Zdrojewski, T., Dubiel, J. S., et al. (2013a): The costs of heart failure in Poland from the public payer's perspective. Polish programme assessing diagnostic procedures, treatment and costs in patients with heart failure in randomly selected outpatient clinics and hospitals at different levels of care: POLKARD. Kardiol Pol, 71, pp. 224-32. DOI: 10.5603/KP.2013.0032

Czech, M., Rosinska, M., Rogalska, J., Staszewska, E., et al. (2013b): Costs of Medically Attended Acute Gastrointestinal Infections: The Polish Prospective Healthcare Utilization Survey. Value in Health Regional Issues, 2, pp. 210-217. DOI: 10.1016/j.vhri.2013.06.011 
Daroczi, T., Bor, R., Fabian, A., Szabo, E., et al. (2016): [Cost-effectiveness trial of selfexpandable metal stents and plastic biliary stents in malignant biliary obstruction]. Orv Hetil., 157, pp. 268-74. DOI: 10.1556/650.2016.30365.

Dasbach, E. J., Nagy, L., Brandtmüller, A. ,Elbasha, E. H. (2010): The cost effectiveness of a quadrivalent human papillomavirus vaccine (6/11/16/18) in Hungary. Journal of Medical Economics, 13, pp. 110-118. DOI: 10.3111/13696990903546013

De Pouvourville, G., Ulmann, P., Nixon, J., Boulenger, S., et al. (2005): The diffusion of health economics knowledge in Europe : The EURONHEED (European Network of Health Economics Evaluation Database) project. Pharmacoeconomics, 23, pp. 113-20. DOI: 10.2165/00019053-200523020-00003.

Devlin, N. J. ,Brooks, R. (2017): EQ-5D and the EuroQol Group: Past, Present and Future. Appl Health Econ Health Policy, 15, pp. 127-137. DOI: 10.1007/s40258017-0310-5

Dimai, H. P., Redlich, K., Schneider, H., Siebert, U., et al. (2012): [Direct and indirect costs of fractures due to osteoporosis in Austria]. Gesundheitswesen, 74, pp. e908. DOI: $10.1055 / \mathrm{s}-0031-1301274$

Dolan, P. (1997): Modeling valuations for EuroQol health states. Med Care, 35, pp. 1095108. DOI: 10.1097/00005650-199711000-00002.

Dorner, T., Strand, V., Cornes, P., Goncalves, J., et al. (2016): The changing landscape of biosimilars in rheumatology. Ann Rheum Dis, 75, pp. 974-82. DOI: 10.1136/annrheumdis-2016-209166

Drummond, M., Brown, R., Fendrick, A. M., Fullerton, P., et al. (2003): Use of pharmacoeconomics information--report of the ISPOR Task Force on use of pharmacoeconomic/health economic information in health-care decision making. Value Health, 6, pp. 407-16. DOI: 10.1046/j.1524-4733.2003.64245.x.

Drummond, M., Sculpher, M. ,Torrance, G. (2005): Methods for the Economic Evaluation of Health Care Programmes (3rd ed.). Oxford, Oxford University PressOxford University Press.

Dubas-Jakobczyk, K., Kocot, E., Seweryn, M. ,Koperny, M. (2016): Production lost due to cervical cancer in Poland in 2012. Med $\mathrm{Pr}$, 67, pp. 289-99. DOI: 10.13075/mp.5893.00378

Dzajkovska, B., Wertheimer, A. I. ,Mrhar, A. (2007): The burden-of-illness study on osteoporosis in the Slovenian female population. Pharm World Sci, 29, pp. 40411. DOI: $10.1007 / \mathrm{s} 11096-007-9091-5$

EMMI. 2017. Az Emberi Eröforrások Minisztériuma szakmai irányelve az epilepsziás rohamok és epilepszia felismeréséröl, kezeléséröl és az epilepsziás betegek gondozásáról.

Elérhető: http://www.hbcs.hu/uploads/jogszabaly/2482/fajlok/epilepszia\%20.pdf, Utolsó letöltés ideje: 2018. 03. 12.

Endarti, D., Riewpaiboon, A., Thavorncharoensap, M., Praditsitthikorn, N., et al. (2018): A Comparison of EQ-5D-3L Index Scores Using Malaysian, Singaporean, Thai, and UK Value Sets in Indonesian Cervical Cancer Patients. Value Health Reg Issues, 15, pp. 50-55. DOI: 10.1016/j.vhri.2017.07.008

Érsek, K., Kovács, T., Wimo, A., Karpati, K., et al. (2010): Costs of dementia in Hungary. J Nutr Health Aging, 14, pp. 633-9. DOI: https://doi.org/10.1007/s12603-0100309-1

Eunethta (2007): EUnetHTA comments on the Discussion Document: "Health in Europe: A Strategic Approach".

EunETHTA. 2019. HTA Core Model. Elérhetö: https://www.eunethta.eu/hta-core-model/, Utolsó letöltés ideje: 02/11/2019. 
EuróPAIBIZOTTSÁG. 2017. State of Health in the EU - Magyarország - Egészségügyi országprofil

Elérhető:

https://ec.europa.eu/health/sites/health/files/state/docs/chp hu hungary.pdf,

Utolsó letöltés ideje: 23/11/2019.

EUROQOL. 2019. Valuation of EQ-5D. Elérhetö: https://euroqol.org/eq-5dinstruments/valuation-of-eq-5d/, Utolsó letöltés ideje: 05/01/2019.

Euroqolgroup (1990): EuroQol--a new facility for the measurement of health-related quality of life. Health Policy, 16, pp. 199-208. DOI:

EuroqOLgROUP. 2004. Measuring Self-Reported Population Health: An International Perspective Based on EQ-5D. Elérhetö: https://euroqol.org/wpcontent/uploads/2016/10/Measuring_Self-Reported_Population_Health_-

An International Perspective based on EQ-5D.pdf, Utolsó letöltés ideje: 07/01/2019.

EUROSTAT. Population structure and ageing, 2005 and 2015. Elérhetö: http://ec.europa.eu/eurostat/statistics-ex-

plained/index.php/File:Population_age_structure_by_major_age_groups_2005_a nd 2015 (\%25 of the total population) YB16.png, Utolsó letöltés ideje: $11 / 12 / 2017$.

Eurostat (2013): European Health Interview Survey (EHIS wave 2) Methodological manual. pp. DOI: $10.2785 / 43280$

EUROSTAT. 2018a. Healthy life years Elérhetö: https://ec.europa.eu/eurostat/statisticsexplained/index.php/Healthy_life_years_statistics, Utolsó letöltés ideje: 24/05/2020.

EUROSTAT. 2018b. Life expectancy at birth. Elérhetö: https://ec.europa.eu/eurostat/web/products-datasets/product?code=sdg_03_10, Utolsó letöltés ideje: 24/05/2020.

Eurostat. 2019. Glossary:Minimum European Health Module (MEHM). Elérhető: https://ec.europa.eu/eurostat/statistics-

explained/index.php/Glossary:Minimum_European_Health_Module_(MEHM), Utolsó letöltés ideje: 24/02/2019.

EUROSTAT. $2020 . \quad$ Healthcare Elérhetö: https://appsso.eurostat.ec.europa.eu/nui/show.do?dataset=hlth_sha11_hf\&lang=e n, Utolsó letöltés ideje: 12/01/2020.

Feig, C., Cheung, K. L., Hiligsmann, M., Evers, S., et al. (2017): Best-worst scaling to assess the most important barriers and facilitators for the use of health technology assessment in Austria. Expert Rev Pharmacoecon Outcomes Res, pp. 1-10. DOI: 10.1080/14737167.2017.1375407

Fejes, M., Varga, B. ,Hollody, K. (2019): [Epidemiology, cost and economic impact of cerebral palsy in Hungary]. Ideggyogy $S z ., 72$, pp. 115-122. doi: . DOI: 10.18071/isz.72.0115.

Ferraz, L. B., Almeida, F. A., Vasconcellos, M. R., Faccina, A. S., et al. (2006): The impact of lupus erythematosus cutaneous on the Quality of life: the BrazilianPortuguese version of DLQI. Qual Life Res, 15, pp. 565-70. DOI: 10.1007/s11136-005-2638-9

Flynn, T. N., Huynh, E., Peters, T. J., Al-Janabi, H., et al. (2015): Scoring the ICECAPA capability instrument. Estimation of a UK general population tariff. Health economics, 24, pp. 258-269. DOI: 10.1002/hec.3014.

Georgieva, V. 2015. Pharmacoeconomic evaluation of surgical and endovascular therapy of brain aneurism. $\mathrm{PhD}$ thesis, Medical University of Sofia. 
Glogovska, P., Ivanov, Y., Hristova, P., Pavlov, P., et al. (2010): Pharmacoeconomic evaluation of the ambulatory and hospital cost of therapy of patients with community acquired respiratory tract infections. Thorasis medicine 2, pp. 52-56.

Golicki, D., Jakubczyk, M., Niewada, M., Wrona, W., et al. (2010): Valuation of EQ-5D health states in Poland: first TTO-based social value set in Central and Eastern Europe. Value Health, 13, pp. 289-97. DOI: 10.1111/j.1524-4733.2009.00596.x

Grabmeier-Pfistershammer, K., Rieger, A., Schrock, T. ,Schlag, M. (2013): Economic burden of late presentation in HIV disease in Austria: a comparison of the initial costs imposed by advanced HIV disease vs. non-late presentation. Wien Klin Wochenschr, 125, pp. 402-7. DOI: 10.1007/s00508-013-0392-5

Greiner, W., Weijnen, T., Nieuwenhuizen, M., Oppe, S., et al. (2003): A single European currency for EQ-5D health states. Results from a six-country study. Eur J Health Econ, 4, pp. 222-31. DOI: 10.1007/s10198-003-0182-5

Gulácsi, L., Boncz, I., Baji, P. ,Pentek, M. (2012) Költségszámítás. In: GULÁCSI, L. (ed.) Egészség-gazdaságtan és techológiaelemzés. Budapest: Medicina Könyvkiadó Nyrt. .

Gulácsi, L., Brodszky, V., Péntek, M. ,Érsek, K. (2011): A certolizumab pegol kezelés rheumatoid arthritisben; irodalmi áttekintés és egészség-gazdaságtani vizsgálat. Budapest, Budapesti Corvinus Egyetem Egészség-gazdaságtani és Egészségügyi Technológiaelemzési Kutatóközpont.

Gulácsi, L., Májer, I., Boncz, I., Brodszky, V., et al. (2007): [Health care costs of acute myocardial infarction in Hungary, 2003-2005]. Orv Hetil, 148, pp. 1259-66. DOI: 10.1556/OH.2007.28109

Gulácsi, L., Rencz, F., Pentek, M., Brodszky, V., et al. (2014a): Transferability of results of cost utility analyses for biologicals in inflammatory conditions for Central and Eastern European countries. Eur J Health Econ, 15 pp. S27-34. DOI: 10.1007/s10198-014-0591-7

Gulácsi, L., Rencz, F., Poór, G., Szekanecz, Z., et al. (2016): Patients' access to biological therapy in chronic inflammatory conditions; per capita GDP does not explain the intercountry differences. Ann Rheum Dis, 75, pp. 942-943. DOI: 10.1136/annrheumdis-2015-208741

Gulácsi, L., Rotar, A. M., Niewada, M., Loblova, O., et al. (2014b): Health technology assessment in Poland, the Czech Republic, Hungary, Romania and Bulgaria. Eur J Health Econ, 15 Suppl 1, pp. S13-25. DOI: 10.1007/s10198-014-0590-8

Hahn, H. B., Melfi, C. A., Chuang, T. Y., Lewis, C. W., et al. (2001): Use of the Dermatology Life Quality Index (DLQI) in a midwestern US urban clinic. $J A m$ Acad Dermatol, 45, pp. 44-8. DOI: 10.1067/mjd.2001.110880

Harangozó, J., Slezák, A., Borsos, K., Németh, O., et al. (2008): Costs of treatment in patients with schizophrenia switched to amisulpride--one-year follow-up. Psychiatr Hung, 23, pp. 464-71.

Herdman, M., Gudex, C., Lloyd, A., Janssen, M., et al. (2011): Development and preliminary testing of the new five-level version of EQ-5D (EQ-5D-5L). Qual Life Res, 20, pp. 1727-36. DOI: 10.1007/s11136-011-9903-x

Herédi, E., Rencz, F., Balogh, O., Gulacsi, L., et al. (2014): Exploring the relationship between EQ-5D, DLQI and PASI, and mapping EQ-5D utilities: a cross-sectional study in psoriasis from Hungary. Eur J Health Econ, 15 Suppl 1, pp. S111-9. DOI: 10.1007/s10198-014-0600-x

Hernlund, E., Svedbom, A., Ivergård, M., Compston, J., et al. (2013): Osteoporosis in the European Union: medical management, epidemiology and economic burden: A report prepared in collaboration with the International Osteoporosis Foundation 
(IOF) and the European Federation of Pharmaceutical Industry Associations (EFPIA). Archives of Osteoporosis, 8, pp. 136. DOI: 10.1007/s11657-013-01361

Herszényi, K., Pap, D., Polgár, K., Jókai, H., et al. (2016): Infekciók potenciális szerepe anti-TNF- $\alpha$ kezelés hatásvesztésének hátterében psoriasisban. MDT Nagygyülés

Hever, N. V., Pentek, M., Ballo, A., Gulacsi, L., et al. (2015): Health related quality of life in patients with bladder cancer: a cross-sectional survey and validation study of the Hungarian version of the Bladder Cancer Index. Pathol Oncol Res, 21, pp. 619-27. DOI: $10.1007 / \mathrm{s} 12253-014-9866-7$

HoEfMAN, R., VAN EXEL, N. ,BRouwer, W. 2011. iMTA Valuation of Informal Care Questionnaire (iVICQ).

Elérhetö: www.bmg.eur.nl/english/imta/publications/manuals questionnaires/on, Utolsó letöltés ideje: 27/07/2017.

Hoefman, R. J., Van Exel, J. ,Brouwer, W. (2013): How to include informal care in economic evaluations. Pharmacoeconomics, 31, pp. 1105-19. DOI: 10.1007/s40273-013-0104-z

Holmerova, I., Hort, J., Rusina, R., Wimo, A., et al. (2016): Costs of dementia in the Czech Republic. Eur J Health Econ, pp. DOI: 10.1007/s10198-016-0842-x

Horvath, C. Z., Sebestyen, A., Osterle, A., Endrei, D., et al. (2014): Economic burden of long-term care of rheumatoid arthritis patients in Hungary. Eur J Health Econ, 15 Suppl 1, pp. S131-5. DOI: 10.1007/s10198-014-0601-9

ICD. 2016. International Statistical Classifcation of Diseases and Related Health Problems, 10th Revision (ICD-10 Version: 2016). Elérhetö: http://apps.who.int/classifica tions/icd10/brows e/2016/en Utolsó letöltés ideje: 21/07/2017.

Inotai, A., Abonyi-Toth, Z., Rokszin, G. ,Voko, Z. (2015): Prognosis, Cost, and Occurrence of Colorectal, Lung, Breast, and Prostate Cancer in Hungary. Value Health Reg Issues, 7, pp. 1-8. DOI: 10.1016/j.vhri.2015.03.020

Iskrov, G., Astigarraga, I., Stefanov, R., Lopez-Bastida, J., et al. (2016): Social/economic costs and health-related quality of life in patients with histiocytosis in Europe. Eur J Health Econ, 17(Suppl 1), pp. 67-78. DOI: 10.1007/s10198-016-0790-5

Iskrov, G. G., Stefanov, R. S., Lopez-Bastida, J., Linertova, R., et al. (2015): Economic Burden And Health-Related Quality Of Life Of Patients With Cystic Fibrosis In Bulgaria. Folia Med (Plovdiv), 57, pp. 56-64. DOI: 10.1515/folmed-2015-0020

Ivanova, Z., Veleva, N., Glogovska, P., Pavlov, P., et al. (2014): Hospital therapy cost of patients with asthma. MEDINFO, 14, pp. 28-31.

Iversen, T., Aas, E., Rosenqvist, G., Hakkinen, U., et al. (2015): Comparative Analysis of Treatment Costs in EUROHOPE. Health Econ, 24 Suppl 2, pp. 5-22. DOI: 10.1002/hec.3262

Jacobs, P., Ohinmaa, A. ,Brady, B. (2005): Providing systematic guidance in pharmacoeconomic guidelines for analysing costs. Pharmacoeconomics, 23, pp. 143-53. DOI:10.2165/00019053-200523020-00006.

Jakubczyk, M., Lipka, I., Paweska, J., Niewada, M., et al. (2016): Cost of severe hypoglycaemia in nine European countries. J Med Econ, 19, pp. 973-82. DOI: 10.1080/13696998.2016.1188823

Jaworski, R., Jankowska, E. A., Ponikowski, P. ,Banasiak, W. (2012): Costs of management of patients with coronary artery disease in Poland: the multicenter RECENT study. Pol Arch Med Wewn, 122, pp. 599-607. DOI: 10.20452/pamw.1533. 
József, K. (2006): Az omalizumabnak, a súlyos asztma új terápiájának költséghatékonysági elemzése Magyarországon. IME Interdiszciplináris Magyar Egészségügy, 5, pp. 42-46.

Kárpáti, K., Májer, I., Boncz, I., Nagy, A., et al. (2007): Social insurance costs of hospital treatment of stroke in Hungary, 2003-2005. Ideggyogy Sz, 60, pp. 311-320.

Kawalec, P. P. ,Malinowski, K. P. (2015): The indirect costs of systemic autoimmune diseases, systemic lupus erythematosus, systemic sclerosis and sarcoidosis: a summary of 2012 real-life data from the Social Insurance Institution in Poland. Expert Rev Pharmacoecon Outcomes Res, 15, pp. 667-73. DOI: 10.1586/14737167.2015.1065733

Khoudri, I., Lamchahab, F. Z., Ismaili, N., Senouci, K., et al. (2013): Measuring quality of life in patients with psoriasis using the Arabic version for Morocco of the Dermatology Life Quality Index. Int J Dermatol, 52, pp. 795-802. DOI: 10.1111/j.1365-4632.2011.05450.x

Kiadaliri, A. A. (2016): A Comparison of Iran and UK EQ-5D-3L Value Sets Based on Visual Analogue Scale. International journal of health policy and management, 6, pp. 267-272. DOI: 10.15171/ijhpm.2016.131

Kiss, C., Lövei, C., Sütő, G. ,Czirják, L. (2005): Prevalence of rheumatoid arthritis in the South-Transdanubian region of Hungary based on a representative survey of 10,000 inhabitants. Journal of Rheumatology, (Oxford), pp. 1688-1690.

Klimeš, J., Vocelka, M., Šedová, L., Doležal, T., et al. (2014): Medical and Productivity Costs of Rheumatoid Arthritis in The Czech Republic: Cost-of-Illness Study Based on Disease Severity. Value in Health Regional Issues, 4, pp. 75-81. DOI: 10.1016/j.vhri.2014.07.004

Kobelt, G., Berg, J., Lindgren, P., Plesnilla, C., et al. (2006): Costs and quality of life of multiple sclerosis in Austria. Eur J Health Econ, 7 Suppl 2, pp. S14-23. DOI: 10.1007/s10198-006-0382-x

Kobelt, G., Eriksson, J., Phillips, G. ,Berg, J. (2017): The burden of multiple sclerosis 2015: Methods of data collection, assessment and analysis of costs, quality of life and symptoms. Mult Scler., 23, pp. 4-16. DOI: 10.1177/1352458517708097.

Kósa József ,Raymond, O. (2008): Költség-minimalizációs elemzés: A Lantus és a detemir bázisinzulinok összehasonlítása a diabetes aktuális terápiás gyakorlatában. IME Interdiszciplináris Magyar Egészségügy, 7, pp. 41-44.

Kovacs, G., Kalo, Z., Jahnz-Rozyk, K., Kyncl, J., et al. (2014): Medical and economic burden of influenza in the elderly population in central and eastern European countries. Hum Vaccin Immunother, 10, pp. 428-40. DOI: 10.4161/hv.26886

Krol, M., Papenburg, J. ,Van Exel, J. (2015): Does including informal care in economic evaluations matter? A systematic review of inclusion and impact of informal care in cost-effectiveness studies. Pharmacoeconomics, 33, pp. 123-135. DOI: $10.1007 / \mathrm{s} 40273-014-0218-\mathrm{y}$

KSH. 2009. Európai lakossági egészségfelmérés. Elérhető: https://www.ksh.hu/elef/archiv/2009/kal_kopp.html, Utolsó letöltés ideje: 2018. 04. 10.

KSH. 2013. Pensions and other benefits in Hungary, 2013. [Központi Statisztikai Hivatal. Nyugdijak és egyéb ellátások, 2013.]. Elérhetö: http://www.ksh.hu/docs/hun/xftp/ idoszaki/regiok/orsz/nyugdij/nyugdij13.pdf Utolsó letöltés ideje: 2017. 04. 22.

$\mathrm{KSH}$. 2017. Gyorsjelntés.

Elérhető: https://www.ksh.hu/docs/hun/xftp/gyor/ker/ker1712.html, Utolsó letöltés ideje: 03/04/2018. 
Kuhlmann, A., Schmidt, T., Treskova, M., Lopez-Bastida, J., et al. (2016): Social/economic costs and health-related quality of life in patients with juvenile idiopathic arthritis in Europe. Eur $J$ Health Econ, 17 pp. 79-87. DOI: 10.1007/s10198-016-0786-1

Kyuchukov, N., Yanev, N., Krachunov, I., Ivanova, Z., et al. (2015): Evaluation of COPD cost for patients on hme oxygen therapy Thorasic medicine, 7, pp. 50-56.

Langenbruch, A., Radtke, M. A., Gutknecht, M. ,Augustin, M. (2019): Does the Dermatology Life Quality Index (DLQI) underestimate the disease-specific burden of psoriasis patients? J Eur Acad Dermatol Venereol, 33, pp. 123-127. DOI: $10.1111 / \mathrm{jdv} .15226$

Larg, A. ,Moss, J. R. (2011): Cost-of-illness studies: a guide to critical evaluation. PharmacoEconomics, 29, pp. 653-71. DOI: 10.2165/11588380-00000000000000 [doi]

László, G. (2010): A solifenacin szerepe a hiperaktív hólyagszindróma kezelésében; irodalmi áttekintés és egészség-gazdaságtani értékelés. Budapest, Budapesti Corvinus Egyetem Egészség-gazdaságtani és Egészségügyi Technológiaelemzési Kutatóközpont.

Leal, J., Luengo-Fernandez, R., Sullivan, R. ,Witjes, J. A. (2016): Economic Burden of Bladder Cancer Across the European Union. Eur Urol, 69, pp. 438-47. DOI: 10.1016/j.eururo.2015.10.024

Lepp-Gazdag, A., Gulácsi, L., Brandtmüller, Á. ,Dávid, T. (2002): A rheumatoid arthritis megbetegedés és ellátás jellemzői Magyarországon. Egészségügyi Gazdasági Szemle, pp. 645-657.

Lesniowska, J., Schubert, A., Wojna, M., Skrzekowska-Baran, I., et al. (2014): Costs of diabetes and its complications in Poland. Eur J Health Econ, 15, pp. 653-60. DOI: 10.1007/s10198-013-0513-0

Lopez-Bastida, J., Linertova, R., Oliva-Moreno, J., Posada-De-La-Paz, M., et al. (2016a): Social/economic costs and health-related quality of life in patients with PraderWilli syndrome in Europe. Eur $J$ Health Econ, 17, pp. 99-108. DOI: 10.1007/s10198-016-0788-z

Lopez-Bastida, J., Linertova, R., Oliva-Moreno, J., Serrano-Aguilar, P., et al. (2016b): Social/economic costs and health-related quality of life in patients with scleroderma in Europe. Eur J Health Econ, 17 pp. 109-17. DOI: 10.1007/s10198016-0789-y

Mandel, M. D., Balint, A., Lovasz, B. D., Gulacsi, L., et al. (2014): Work disability and productivity loss in patients with inflammatory bowel diseases in Hungary in the era of biologics. Eur J Health Econ, 15 Suppl 1, pp. S121-8. DOI: 10.1007/s10198-014-0603-7

Mandrik, O., Knies, S., Kalo, Z. ,Severens, J. L. (2015): Reviewing Transferability in Economic Evaluations Originating from Eastern Europe. Int J Technol Assess Health Care, 31, pp. 434-41. DOI: 10.1017/S0266462315000677

Marada, G., Nagy, A., Sebestyen, A., Endrei, D., et al. (2016): [Reimbursement of public dental care in Germany, the United Kingdom, Hungary and Poland]. Orv Hetil, 157, pp. 547-53. DOI: 10.1556/650.2016.30405

Maresova, P. ,Zahalkova, V. (2016): The economic burden of the care and treatment for people with Alzheimer's disease: the outlook for the Czech Republic. Neurol Sci, 37, pp. 1917-1922. DOI: 10.1007/s10072-016-2679-6

Mayer, S., Kiss, N., Laszewska, A. ,Simon, J. (2017): Costing evidence for health care decision-making in Austria: A systematic review. PLoS One, 12, pp. e0183116. DOI: 10.1371/journal.pone.0183116 
Mayrshofer, F., Hertl, M., Sinkgraven, R., Sticherling, M., et al. (2005): Significant decrease in quality of life in patients with pemphigus vulgaris. Results from the German Bullous Skin Disease (BSD) Study Group. J Dtsch Dermatol Ges, 3, pp. 431-5. DOI: 10.1111/j.1610-0387.2005.05722.x

Mazzotti, E., Barbaranelli, C., Picardi, A., Abeni, D., et al. (2005): Psychometric properties of the Dermatology Life Quality Index (DLQI) in 900 Italian patients with psoriasis. Acta Derm Venereol, 85, pp. 409-13. DOI: 10.1080/00015550510032832

Meszner, Z., Molnar, Z., Rampakakis, E., Yang, H. K., et al. (2017): Economic burden of varicella in children 1-12 Years of age in Hungary, 2011-2015. BMC Infect Dis., 17, pp. 495. DOI:

Minier, T., Pentek, M., Brodszky, V., Ecseki, A., et al. (2010): Cost-of-illness of patients with systemic sclerosis in a tertiary care centre. Rheumatology (Oxford), 49, pp. 1920-8. DOI: 10.1093/rheumatology/keq165

Mlcoch, T., Klimes, J., Fila, L., Vavrova, V., et al. (2017): Cost-of-illness analysis and regression modeling in cystic fibrosis: a retrospective prevalence-based study. Eur J Health Econ, 18, pp. 73-82. DOI: 10.1007/s10198-015-0759-9

Mork, C., Wahl, A. ,Moum, T. (2002): The Norwegian version of the dermatology life quality index: a study of validity and reliability in psoriatics. Acta Derm Venereol, 82, pp. 347-51. DOI: 10.1080/000155502320624078.

Mozzi, A., Meregaglia, M., Lazzaro, C., Tornatore, V., et al. (2016): A comparison of EuroQol 5-Dimension health-related utilities using Italian, UK, and US preference weights in a patient sample. ClinicoEconomics and Outcomes Research: CEOR, 8, pp. 267-274. DOI: 10.2147/CEOR.S98226

Nagy, B., Timar, G., Jozwiak-Hagymasy, J., Kovacs, G., et al. (2014): The costeffectiveness of ulipristal acetate tablets in treating patients with moderate to severe symptoms of uterine fibroids. Eur J Obstet Gynecol Reprod Biol, 175, pp. 75-81. DOI: 10.1016/j.ejogrb.2014.01.022

Németh, B., Jozwiak-Hagymasy, J., Kovacs, G., Kovacs, A., et al. (2018): Costeffectiveness of possible future smoking cessation strategies in Hungary: results from the EQUIPTMOD. Addiction., 113, pp. 76-86. DOI: 10.1111/add.14089.

Nerat, T. ,Kos, M. (2013): Burden of Type 2 Diabetes from the Healthcare Payer Perspective in Slovenia Slovenian Journal of Public Health, 52, pp. 162-180. DOI: $10.2478 /$ sjph-2013-0018

Neubauer, S., Holle, R., Menn, P., Grossfeld-Schmitz, M., et al. (2008): Measurement of informal care time in a study of patients with dementia. Int. Psychogeriatr, pp. 1160-1175. DOI: 10.1017/S1041610208007564.

Nixon, J., Rice, S., Drummond, M., Boulenger, S., et al. (2009): Guidelines for completing the EURONHEED transferability information checklists. Eur $J$ Health Econ, 10, pp. 157-65. DOI: 10.1007/s10198-008-0115-4

OECD. 2017. Health at a Glance 2017. Elérhető: https://www.oecdilibrary.org/content/publication/health_glance-2017-en, Utolsó letöltés ideje: $08 / 12 / 2018$.

Oecd (2019): Hungary: Country Health Profile 2019.

OECD. 2020. Health spending (indicator). Elérhető: https://data.oecd.org/healthres/health-spending.htm, Utolsó letöltés ideje: $13 / 05 / 2020$.

OEP. 2009. A plakkos psoriasis diagnosztikája és kezelése "Finanszírozási protokoll háttéranyag"

Elérhetö: 
http://site.oep.hu/prot/A_plakkos_psoriasis_finanszirozasi_protokoll_hatteranya ga.pdf, Utolsó letöltés ideje: 03/13/2018.

OEP. 2010a. A sclerosis multiplex diagnosztikája és kezelése A finanszirozási protokoll háttéranyaga

Elérhető:

http://site.oep.hu/prot2/23 A sclerosis multiplex diagnosztikaja es kezelese f inanszirozasi_protokoll_hatteranyag.pdf, Utolsó letöltés ideje: 2018. 03. 13.

OEP. 2010b. A szkizofrénia antipszichotikus gyógyszeres kezelése A finanszírozási protokoll háttéranyaga Elérhetö: http://site.oep.hu/prot2/25_A_szkizofrenia_antipszichotikus_gyogyszeres_kezel ese finanszirozasi protokoll hatteranyag.pdf, Utolsó letöltés ideje: 2018.03.13.

OEP. 2013. A Parkinson betegségcsoport diagnosztikájának és kezelésének finanszírozási eljárásrendje (eljárásrend).

Elérhető: http://www.neak.gov.hu/data/cms989733/0626_parkinson_finanszirozasi_protok ollja.pdf, Utolsó letöltés ideje: 03/13/2018.

Olesen, J., Gustavsson, A., Svensson, M., Wittchen, H. U., et al. (2012): The economic cost of brain disorders in Europe. Eur J Neurol, 19, pp. 155-62. DOI: 10.1111/j.1468-1331.2011.03590.x

Olsen, J. A., Lamu, A. N. ,Cairns, J. (2018): In search of a common currency: A comparison of seven EQ-5D-5L value sets. Health Econ, 27, pp. 39-49. DOI: 10.1002/hec.3606

Onukwugha, E., Mcrae, J., Kravetz, A., Varga, S., et al. (2016): Cost-of-Illness Studies: An Updated Review of Current Methods. PharmacoEconomics, 34, pp. 43-58. DOI: $10.1007 / \mathrm{s} 40273-015-0325-4$

Péntek, M., Baji, P., Pogany, G., Brodszky, V., et al. (2014): Health Related Quality of Life of Patients and Their Caregivers In Rare Diseases Results of the Burqol-Rd Project In Hungary. Value Health, 17, pp. A538. DOI: 10.1016/j.jval.2014.08.1724

Pentek, M., Bereczki, D., Gulacsi, L., Mikudina, B., et al. (2013): Survey of adults living with epilepsy in Hungary: health-related quality of life and costs [Epilepsziával elő felnőttek felmérése Magyarországon: eletminőség és költségek.]. Ideggyogy $S z, 66$, pp. 251-61. DOI:

Péntek, M., Beretzky, Z., Brodszky, V., Szabó, A., et al. (2020): A magyarországi lakosság egészséggel összefüggő munkaképessége: keresztmetszeti reprezentatív felmérés a Munkaképességre és Tevékenységcsökkenésre vonatkozó kérdőívvel. Orvosi Hetilap, accepted for publication

Péntek, M., Brodszky, V., Biro, Z., Kolkedi, Z., et al. (2017a): Subjective health expectations of patients with age-related macular degeneration treated with antiVEGF drugs. BMC Geriatr, 17, pp. 233. DOI: 10.1186/s12877-017-0619-9

Péntek, M., Gulacsi, L., Brodszky, V., Baji, P., et al. (2016a): Social/economic costs and health-related quality of life of mucopolysaccharidosis patients and their caregivers in Europe. Eur J Health Econ., 17, pp. 89-98. doi: 10.1007/s10198016-0787-0. Epub 2016 Apr 9.

Péntek, M., Gulácsi, L., Majoros, A., Piroth, C., et al. (2012a): Health related quality of life and productivity of women with overactive bladder [Hiperaktív hólyagszindrómával élő nők életminősége és munkaképessége]. Orv Hetil, 153, pp. 1068-76. DOI: 10.1556/oh.2012.29384

Péntek, M., Gulácsi, L., Rózsa, C., Simo, M., et al. (2012b): Health status and costs of ambulatory patients with multiple sclerosis in Hungary. Ideggyogy $S z, 65$, pp. 316-24. DOI: 
Péntek, M., Gulácsi, L., Toth, E., Baji, P., et al. (2016b): Ten-year fracture risk by FRAX (®) of women with osteoporosis attending osteoporosis care in Hungary [A szakellátásban megjelenő osteoporosisos nők 10 éves csonttöréskockázata a FRAX(®) alapján.]. Orv Hetil, 157, pp. 146-53. DOI: 10.1556/650.2015.30347 [doi]

Péntek, M., Harangozó, J., Egerházi, A., Kelemen, O., et al. (2012c): Health related quality of life and disease burden of patients with schizophrenia in Hungary [A szkizofréniával elő betegek egeszséggel összefüggő életminősége es betegségterhe Magyarorszégon.]. Psychiatr Hung, 27, pp. 4-17. DOI:

Péntek, M., Herczegfalvi, A., Molnár, M. J., Szonyi, L. P., et al. (2016c): Disease burden of Duchenne muscular dystrophy patients and their caregivers [Duchenne-féle izomdisztrófiával élő betegek és gondozóik betegségterhe] Ideggyogy $S z, 69$, pp. 183-193.

Péntek, M., Kobelt, G., Berg, J., Capsa, D., et al. (2017b): New insights into the burden and costs of multiple sclerosis in Europe: Results for Hungary. Mult Scler., 23, pp. 91-103. DOI: 10.1177/1352458517708142.

Péntek, M., Kobelt, G., Czirjak, L., Szekanecz, Z., et al. (2007): Costs of rheumatoid arthritis in Hungary. J Rheumatol, 34, pp. 1437.

Péntek, M., Lakatos, P. L., Oorsprong, T., Gulacsi, L., et al. (2017c): Access to biologicals in Crohn's disease in ten European countries. World J Gastroenterol., 23, pp. 6294-6305. . DOI: 10.3748/wjg.v23.i34.6294.

Péntek, M., Szekanecz, Z., Czirjak, L., Poor, G., et al. (2008): [Impact of disease progression on health status, quality of life and costs in rheumatoid arthritis in Hungary]. Orv Hetil, 149, pp. 733-41. DOI: 10.1556/OH.2008.28294

Pentek, T., Newenhouse, E., O'brien, B. ,Chauhan, A. S. (2017): Development of a Topical Resveratrol Formulation for Commercial Applications Using Dendrimer Nanotechnology. Molecules, 22, pp. DOI: 10.3390/molecules22010137

Prast, J., Oppelt, P., Shamiyeh, A., Shebl, O., et al. (2013): Costs of endometriosis in Austria: a survey of direct and indirect costs. Arch Gynecol Obstet, 288, pp. 56976. DOI: $10.1007 / \mathrm{s} 00404-013-2793-0$

Pulay, A. J., Bitter, I., Papp, S., Gulácsi, L., et al. (2016): Exploring the Relationship between Quality of Life (EQ-5D) and Clinical Measures in Adult Attention Deficit Hyperactivity Disorder (ADHD). Applied Research in Quality of Life, 12, pp. 409-424. DOI: $10.1007 / \mathrm{s} 11482-016-9467-6$

Raspe, A., Matthis, C., Scheidt-Nave, C. ,Raspe, H. (1998): European Study of Vertebral Osteoporosis (EVOS): design and implementation in 8 German study centers. Med Klin (Munich), 93 Suppl 2, pp. 12-6,18. DOI: 10.1007/BF03041993.

REILLY-AsSOCIATES. 2019. WPAI General Information. Elérhető: http://www.reillyassociates.net/WPAI_General.html, Utolsó letöltés ideje: 06/09/2019.

Reilly, M. C., Bracco, A., Ricci, J. F., Santoro, J., et al. (2004): The validity and accuracy of the Work Productivity and Activity Impairment questionnaire--irritable bowel syndrome version (WPAI:IBS). Aliment Pharmacol Ther, 20, pp. 459-67. DOI: 10.1111/j.1365-2036.2004.02091.x

Rencz, F. (2012): A jóindulatú prosztata-megnagyobbodás egészség-gazdaságtani elemzése. Köz-Gazdaság, 7, pp. 135-151. DOI:

Rencz, F., Brodszky, V., Pentek, M., Balogh, O., et al. (2014): Disease burden of psoriasis associated with psoriatic arthritis in Hungary [Arthritis psoriaticával társuló középsúlyos és súlyos psoriasis betegségterhe Magyarországon]. Orv Hetil, 155, pp. 1913-1921. DOI: 10.1556/oh.2014.30044 
Rencz, F., Gulacsi, L., Drummond, M., Golicki, D., et al. (2016): EQ-5D in Central and Eastern Europe: 2000-2015. Qual Life Res, 25, pp. 2693-2710. DOI: 10.1007/s11136-016-1375-6

Rencz, F., Gulacsi, L., Pentek, M., Gecse, K. B., et al. (2017): Cost-utility of biological treatment sequences for luminal Crohn's disease in Europe. Expert Rev Pharmacoecon Outcomes Res., 17, pp. 597-606. doi: 10.1080/14737167.2017.1322509. Epub 2017 Apr 28. DOI: 10.1080/14737167.2017.1322509.

Rencz, F., Hollo, P., Karpati, S., Pentek, M., et al. (2015a): Moderate to severe psoriasis patients' subjective future expectations regarding health-related quality of life and longevity. J Eur Acad Dermatol Venereol, 29, pp. 1398-405. DOI: $10.1111 / j \mathrm{jv} .12884$

Rencz, F., Kemeny, L., Gajdacsi, J. Z., Owczarek, W., et al. (2015b): Use of biologics for psoriasis in Central and Eastern European countries. J Eur Acad Dermatol Venereol, 29, pp. 2222-30. DOI: 10.1111/jdv.13222

Rencz, F., Kovacs, A., Brodszky, V., Gulacsi, L., et al. (2015c): Cost of illness of medically treated benign prostatic hyperplasia in Hungary. Int Urol Nephrol, 47, pp. 1241-9. DOI: 10.1007/s11255-015-1028-7

Rencz, F., Péntek, M., Bortlik, M., Zagorowicz, E., et al. (2015d): Biological therapy in inflammatory bowel diseases: access in Central and Eastern Europe. World journal of gastroenterology, 21, pp. 1728-1737. DOI: 10.3748/wjg.v21.i6.1728

Rencz, F., Poor, A. K., Pentek, M., Hollo, P., et al. (2018): A detailed analysis of 'not relevant' responses on the DLQI in psoriasis: potential biases in treatment decisions. J Eur Acad Dermatol Venereol, 32, pp. 783-790. DOI: 10.1111/jdv.14676

Rios-Diaz, A. J., Lam, J., Ramos, M. S., Moscoso, A. V., et al. (2016): Global Patterns of QALY and DALY Use in Surgical Cost-Utility Analyses: A Systematic Review. PLoS One, 11, pp. e0148304. DOI: 10.1371/journal.pone.0148304

Rodríguez-Blázquez, C., Forjaz, M., Lizán, L., Paz, S., et al. (2015): Estimating the direct and indirect costs associated with Parkinson's disease. Expert Rev Pharmacoecon Outcomes Res, 15, pp. 889-911. DOI: 10.1586/14737167.2015.1103184

Rowen, D., Dixon, S., Hernández-Alava, M. ,Mukuria, C. (2016): Estimating informal care inputs associated with EQ-5D for use in economic evaluation. Eur J Health Econ, 17, pp. 733-744. DOI: 10.1007/s10198-015-0718-5

Scuffham, P. A. ,Kosa, J. (2006): The cost-effectiveness of fluvastatin in Hungary following successful percutaneous coronary intervention. Cardiovasc Drugs Ther, 20, pp. 309-17. DOI: 10.1007/s10557-006-8877-3

Simoens, S., Dunselman, G., Dirksen, C., Hummelshoj, L., et al. (2012): The burden of endometriosis: costs and quality of life of women with endometriosis and treated in referral centres. Hum Reprod, 27, pp. 1292-9. DOI: 10.1093/humrep/des073

Stambu, I. ,Stoicescu, I. P. (2013): [Estimation of direct medical costs of chronic obstructive pulmonary disease over 12 months]. Pneumologia, 62, pp. 86-92. DOI:

Stiglitz, J. E. (2000): A kormányzati szektor gazdaságtana. Budapest, KRK-KERSZÖV Jogi és Üzleti Kiadó Kft.

Stoicescu, I. P., Mihaescu, T., Azoicai, D., Arama, V., et al. (2007): [Preliminary assessment of Streptococcus pneumoniae, pneumonia, economical and clinical burden in Romania]. Pneumologia, 56, pp. 118-23. DOI: 10.1016/j.ijid.2010.02.2262. 
Szmurlo, D., Fundament, T., Ziobro, M., Kruntoradova, K., et al. (2014): Costs of multiple sclerosis - extrapolation of Czech data to Polish patients. Expert Rev Pharmacoecon Outcomes Res, 14, pp. 451-8. DOI: 10.1586/14737167.2014.906305

Tamás, G., Gulácsi, L., Bereczki, D., Baji, P., et al. (2014): Quality of life and costs in Parkinson's disease: a cross sectional study in Hungary. PLoS One, 9, pp. e107704. DOI: 10.1371/journal.pone.0107704

Tichopad, A., Mullerova, J., Jackowska, T., Nemes, E., et al. (2016): Cost Burden of Severe Community-Acquired Rotavirus Gastroenteritis Requiring Hospitalization in the Czech Republic, Slovakia, Poland, and Hungary: A Retrospective Patient Chart Review. Value Health Reg Issues, 10, pp. 53-60. DOI: 10.1016/j.vhri.2016.07.005

Tichopad, A., Roberts, C., Gembula, I., Hajek, P., et al. (2013): Clinical and economic burden of community-acquired pneumonia among adults in the Czech Republic, Hungary, Poland and Slovakia. PLoS One, 8, pp. e71375. DOI: 10.1371/journal.pone.0071375

Todorova, K. 2007. Pharmacoeconomic analysis of the gestational diabetes therapy during pregnancy. $\mathrm{PhD}$ thesis, Medical University of Sofia.

Trapero-Bertran, M., Leidl, R., Munoz, C., Kulchaitanaroaj, P., et al. (2018): Estimates of costs for modelling return on investment from smoking cessation interventions. Addiction., 113, pp. 32-41. DOI: 10.1111/add.14091

Twiss, J., Meads, D. M., Preston, E. P., Crawford, S. R., et al. (2012): Can we rely on the Dermatology Life Quality Index as a measure of the impact of psoriasis or atopic dermatitis? J Invest Dermatol, 132, pp. 76-84. DOI: 10.1038/jid.2011.238

Vallejo-Torres, L., Pujol, M., Shaw, E., Wiegand, I., et al. (2018): Cost of hospitalised patients due to complicated urinary tract infections: a retrospective observational study in countries with high prevalence of multidrug-resistant Gram-negative bacteria: the COMBACTE-MAGNET, RESCUING study. BMJ Open., 8, pp. e020251. DOI: 10.1136/bmjopen-2017-020251.

Valov, V., Doneva, M., Borisova, A. M., Tankova, T., et al. (2014): Regional differences in diabetic patients' pharmacotherapy in Bulgaria. Eur Rev Med Pharmacol Sci, 18, pp. 1499-506.

Van Den Berg, B., Brouwer, W. B. ,Koopmanschap, M. A. (2004): Economic valuation of informal care. An overview of methods and applications. Eur J Health Econ, 5, pp. 36-45. DOI: 10.1007/s10198-003-0189-y

Verbakel, E., Tamlagsronning, S., Winstone, L., Fjaer, E. L., et al. (2017): Informal care in Europe: findings from the European Social Survey (2014) special module on the social determinants of health. Eur J Public Health, 27, pp. 90-95. DOI: 10.1093/eurpub/ckw229

Vlachantoni, A., Evandrou, M., Falkingham, J. ,Robards, J. (2013): Informal care, health and mortality. Maturitas, 74, pp. 114-8. DOI: 10.1016/j.maturitas.2012.10.013

Vokó, Z., Nagyjánosi, L., Margitai, B., Kovi, R., et al. (2012): Modeling costeffectiveness of cervical cancer screening in Hungary. Value Health., 15, pp. 3945. DOI: 10.1016/j.jval.2011.10.003. DOI: 10.1016/j.jval.2011.10.003.

Von Campenhausen, S., Winter, Y., Gasser, J., Seppi, K., et al. (2009): [Cost of illness and health service patterns in Morbus Parkinson in Austria]. Wien Klin Wochenschr, 121, pp. 574-82. DOI: 10.1007/s00508-009-1223-6

Wagner, E. (2011): Direct costs of osteoarthritis. Wien Med Wochenschr, 161, pp. 44-52. DOI: $10.1007 / \mathrm{s} 10354-010-0858-2$ 
Wagner, E. (2012): [Costs of non-specific low back pain in Austria]. Wien Med Wochenschr, 162, pp. 92-8. DOI: 10.1007/s10354-011-0050-3

Willich, S. N., Nocon, M., Kulig, M., Jaspersen, D., et al. (2006): Cost-of-disease analysis in patients with gastro-oesophageal reflux disease and Barrett's mucosa. Aliment Pharmacol Ther, 23, pp. 371-6. DOI: 10.1111/j.1365-2036.2006.02763.x

Wimo, A., Von Strauss, E., Nordberg, G., Sassi, F., et al. (2012): Time spent on informal and formal care giving for persons with dementia in Sweden. Health Policy, pp. 255-268. DOI: 10.1016/s0168-8510(02)00010-6.

Winter, Y., Von Campenhausen, S., Brozova, H., Skoupa, J., et al. (2010): Costs of Parkinson's disease in eastern Europe: a Czech cohort study. Parkinsonism Relat Disord, 16, pp. 51-6. DOI: 10.1016/j.parkreldis.2009.07.005

Wrona, W., Hermanowski, T., Golicki, D., Jakubczyk, M., et al. 2010. Assessing productivity and activity impairment due to illness in Poland. ISPOR 13th Annual European Congress, Prague, Czech Republic.

Zemplenyi, A. T., Mangel, L., Kalo, Z., Endrei, D., et al. (2016): [A microcost analysis of radiation therapy of localized prostate cancer]. Orv Hetil, 157, pp. 461-8. DOI: $10.1556 / 650.2016 .30392$

Zrubka, Z. (2017): Measurement and health economic evaluation of informal care [Az informális ellátás mérése és egészség-gazdaságtani értékelése ]. Orv Hetil, 158, pp. 1363-1372. DOI: 10.1556/650.2017.30841

Zrubka, Z., Beretzky, Z., Hermann, Z., Brodszky, V., et al. (2019): A comparison of European, Polish, Slovenian and British EQ-5D-3L value sets using a Hungarian sample of 18 chronic diseases. Eur J Health Econ, 20, pp. 119-132. DOI: 10.1007/s10198-019-01069-8 